\title{
Early Political Discord in Kenya: European Settlers' Political Struggles in the East Africa Protectorate, 1902-1912
}

\author{
Makhete Fall
}

Follow this and additional works at: https://researchrepository.wvu.edu/etd

\section{Recommended Citation}

Fall, Makhete, "Early Political Discord in Kenya: European Settlers' Political Struggles in the East Africa Protectorate, 1902-1912" (2016). Graduate Theses, Dissertations, and Problem Reports. 5569.

https://researchrepository.wvu.edu/etd/5569

This Dissertation is protected by copyright and/or related rights. It has been brought to you by the The Research Repository @ WVU with permission from the rights-holder(s). You are free to use this Dissertation in any way that is permitted by the copyright and related rights legislation that applies to your use. For other uses you must obtain permission from the rights-holder(s) directly, unless additional rights are indicated by a Creative Commons license in the record and/ or on the work itself. This Dissertation has been accepted for inclusion in WVU Graduate Theses, Dissertations, and Problem Reports collection by an authorized administrator of The Research Repository @ WVU.

For more information, please contact researchrepository@mail.wvu.edu. 


\title{
Early Political Discord in Kenya: European Settlers' Political
}

Struggles in the East Africa Protectorate, 1902-1912

\author{
Makhete Fall \\ Dissertation submitted to the \\ Eberly College of Arts and Social Sciences \\ At West Virginia University \\ In partial fulfillment of the requirements for the degree of \\ Doctor of Philosophy In History
}

Robert M. Maxon, Ph. D., Chair

Joseph M. Hodge, Ph. D.

Mark B. Tauger, Ph. D.

Tamba M'Bayo, Ph. D.

Brent Mc Cusker, Ph. D.

Department of History, Morgantown, West Virginia

2016

Keywords: European Settlers, Colonists' Association, Legislative Council, East African Protectorate, Convention of Associations, Colonial Office, Land, Labor, Taxation. Copyright 2016 Makhete Fall 


\section{Abstract \\ Early Political Discord in Kenya: European Settlers' Political Struggles in \\ the East Africa Protectorate, 1902-1912}

\section{Makhete Fall}

This study of European settlers' political struggles encompasses a ten-year period (190212) during which the foundations of Kenya's modern politics were established. The dissertation follows political contestation originating from the East Africa Protectorate's small European settler community during the administrations of four commissioners/governors. The politics of this period involved varied individuals and organizations that sought to move the colonial state in the direction of policies European politicians advocated in such critical areas as land and labor, the administration of justice, and in the system of government that applied to them and other residents of the protectorate. The settler politicians pushed for a voice in protectorate affairs on the way to the achievement of responsible government on the pattern of South Africa, from which so many of them came to the Kenya highlands. The drive to attain a "white man's country" that marked this decade was thus very critical for future politics. The segregated system demanded by the Europeans had a huge impact on Kenyan history as did the types of organizations they founded and the tactics they adopted. Nevertheless, the European political struggles, while influential, never led to European political control and the establishment of a minority-ruled Kenya as the political agitation did not cause the Colonial Office to bow to the settler politicians' demands. 


\section{Dedication}

Robert and Evelyn Moore, my Mother N'deye N'dack Toure, Father Massow Fall, Sister Coumba Fall and Cherif, Brothers Khaly and Babacar, to all family members, my American family and friend Dr. Larry Clarke and his wife. Dr. Robert Maxon, Dr. Zdatny and family, Dr.Quigley and all my professors. Pastor Kirk Haas, his wife and family, Robert Moratoya and family and all migrants transiting from Africa to Europe. 
Early Political Discord in Kenya: European Settlers' Political Struggles in the East Africa Protectorate, 1902-1912 ......................... i

Abstract ............................................................................................ ii

Dedication ............................................................................................ iii

Abbreviations used in the work ........................................................... vii

Chapter 1 ...................................................................................1

Background to European Settler Politics in the East Africa Protectorate, 1902-1912

Introduction........................................................................1

Research Objectives.............................................................................4

Background to the Study..............................................................8

Structure of the Dissertation...........................................................18

Review of Related Literature...........................................................19

Conclusion..............................................................................................29

Chapter 2 (........................................................................................... 31

An Open Invitation to Some Conflictive British Outlanders into the EAP: A Social and Political Struggle in the Making

Introduction......................................................................................31

Sir Charles Eliot: The progenitor of European settlement in the EAP..............................................................................................33

Eliot's Plan to Introduce European Settlers......................................37

New Rules Under Eliot....................................................................41

European Colonists' Response to Eliot's Settlement

Invitation.........................................................................................50

Widening the Gate for More Settlers...............................................59 
The Start of European Political Organization.....................................63

The End of Eliot's Administration and Its Consequences...................69

Conclusion............................................................................................80

Chapter 3 [...........................................................................................883

Shifting Gears: A New Man on the Spot, Colonial Office Takeover and European Settlers' First Political Demands

Introduction....................................................................................884

Stewart's Administration and the European Settlers'

Influence....................................................................................86

Stewart, the Land Issue and the Colonial Office

Takeover....................................................................................999

The Colonial Office Takes Over.....................................................109

The Colonists' Association Demands..............................................125

Conclusion.................................................................................138

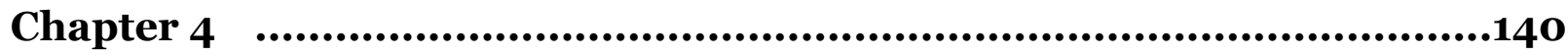

The age of conflicts and failures in Sadler's administration, 1906-1909: European settlers' violations of the Africans' rights and intense political agitations in the EAP

Introduction ....................................................................................140

The Appointment of Sadler: A Familiar Face in the EAP..................141

The Colonial Office, Sadler and the Settlers......................................150

The Politics of Violence, the Meaning of Grogan's Flogging

of African Servants in the EAP.......................................................157

Significance of Grogan's Incident..................................................174

Delamere and the Colonists' Association Claim for Cheap 
Labor Troubles and Significance of Delamere's

Indian Question............................................................................191

Conclusion.

Chapter 5 198

The peak of European settlers' political influence and interference in the East Africa Protectorate's administration under Governor Girouard from 1909 to 1912

Introduction................................................................................208

Sir Percy Girouard as the New Man in the Spot...............................212

Sir Percy Girouard's general constats de faits of the protectorate's status quo and his inclination towards the

European

settlers.

Liasons dangereuses, Girouard and the European Settlers'

Alliance.

The dragging issues of the Land Bill implementation, sufficient labor supply and

taxation.

Together as one: The European setttlers' Convention of

Associations.

Death of an African and the case of a flagrant miscarriage of justice.

The second Maasai move: Stirring up a hornet's nest......................241

The demise of the European settlers' ally:

Afait

accompli.

Conclusion.................................................................................248

Chapter 6 .250

Conclusion................................................................................250 
Bibliography

\section{Abbreviations}

APD Africa Protectorate Department

CA Colonists' Association

C of A Convention of Associations

CO Colonial Office

CS Colonial State

EAD East Africa Department

EAP East Africa Protectorate

E. A. S. East African Standard

FO Foreign Office

HMSO High Majesty Stationnary Office

ICC International Criminal Court

IO India Office

Legco Legislative Council

M. P. Member of Parliament

NLC Native Labour Commission

$\mathbf{S}$ of S Secretary of State

Commissioners and Governors of the East Africa Protectorate 1900 to 1912

Sir Charles Eliot 1900-1904

Sir Donald Stewart 1904- 1905

Sir James Hayes Sadler

1905-1909 (Commissioner 1905-6, then

Governor)

Sir Percy Girouard

Tables.

$1909-1912$ 


\section{Chapter 1}

\section{Background to European Settler Politics in the East Africa protectorate, $\underline{1902-1912}$}

Introduction

Although now largely forgotten, the political history of Kenya for the first half of the twentieth century was dominated by the politics of race. The East Africa Protectorate (EAP), later the Colony and Protectorate of Kenya, was a British colony characterized by a plural society. There were European, Asian and Arab minorities resident in the protectorate as well as the African majority. That diversity had the potential of creating a dynamic market and boosting commerce along the Uganda railroad and in the growing cities. Agriculture and trade were thought to be the pillar foundation for a rapid economic development beneficial to all parties present in the protectorate and mostly to Britain, the new mother country. Since Kenya stood as a Crown Colony (Kenya became a crown colony in 1920), it was normally from Downing Street, the political nerve center of the empire, where future policy towards the region was formulated.

Nevertheless, constructing an effective and fair administration of the protectorate from the metropolis was not an easy task. Apparently, the officials representing the socalled "good intentions" of the British Crown in the region had their own agenda. Among them, Sir Charles Norton Edgecombe Eliot (1862-1931), the Commissioner of the EAP from 1900-1904, decided that the influx of European settlers would be a key factor for the future economic development of the region. Eliot thought that European settlement in the EAP, if well managed, would significantly reduce or even eliminate the British government's subsidies to the protectorate. Throughout his tenure, he worked on encouraging European settlement coming mainly from South Africa. Eliot believed that 
future policy in the EAP should be based on European primacy, which meant that European interests should override those of the African, Arab and Asian communities. Eliot did not last very long as Commissioner of the EAP, but he set the tone for nearly all the following officials who also felt pressured by the settlers' persistent push for more political concessions. That mind set turned Kenya into "one of the most controversial dependencies of the British Empire."1 There were always political problems in coordinating policies between London and the EAP. The ten years covered by this study (1902-1912) indicate that throughout the entire period of British rule, the colonial rulers as well as the inhabitants of the region struggled to find the most appropriate political structure for the colony. In Struggle for Kenya, Robert Maxon dealt with the issue arguing that: The $\mathrm{CO}$ [Colonial Office] in London "struggled to maintain initiative and control in these years in the face of several, often contradictory, interested parties and pressure groups" among the most influential were "Kenya's colonial state, the European settlers and Indian residents there, the India Office (IO) and the government of India, missionaries, humanitarians and capitalists in Britain itself, and the African majority in Kenya." 2

An adequate political structure for the colony always included a prominent role in the apparatus for the European residents who were thought to be the exclusive agents of any potential economic development. The unofficial or European settler segment of the white population played a very critical role in the political struggles that marked the early colonial period. For example, the demands made by the European settlers have

\footnotetext{
${ }^{1}$ Robert Maxon, Struggle for Kenya (London: Associated University Presses, 1993), 13.

2 Ibid.
} 
more often been interpreted by colonial and imperial historians as providing a target for protest from African, Arab and Asian political leaders.

After the initial years of colonial rule, European settlers played the largest and most influential role in the colony's political system. As late as 1955, for example, influential American writer John Gunther confidently predicted that Kenya's first prime minister at independence would be a European settler. He affirmed that if he were an African, he would rather be under British administration than any other, for "Great Britain is the only colonial power that has as its official policy the systematic training of Africans for self-government."3 He did not fully understand that the British did not just pour money into East Africa to lift up the Africans and show them a potential political path leading to future economic development. Self-government, moreover, in the eyes of the Europeans, referred to the possibilities of political independence for the settlers who wanted to control the protectorate for their own gains. The EAP was never like the case of South Africa, where the European settlers had self-government.

From the time ministerial government was introduced in 1954 until 1969, there was at least one European in Kenya's Council of Ministers. In light of this information, it is important to examine the early examples of European political activity in the region just before, and just after, the CO assumption of supervision over the EAP in 1905. This study will seek to provide such an examination in the period stretching to the end of Sir Percy Girouard's administration 1909-1912.

The 1902-1912 periods, though relatively brief, is nevertheless a particularly critical one in the history of Kenya. During this time, European settlement entrenched

\footnotetext{
3 John Gunther, Inside Africa (New York: Harper, 1955), 681.
} 
itself as a major factor in the EAP's economic and social fabric. These years witnessed the demand that land be set aside exclusively for European farming, known as the white highlands, and European agriculture began a struggle for prosperity.

Those economic goals played a large part in European settler politics during this earlier formative period as settler leaders organized politically and began agitation for exclusive control of land in the highlands as well as favorable conditions relating to purchase and tenure. The settler farmers also mobilized politically in an attempt to gain the backing of the CS for markets and infrastructure and, most importantly, cheap African labor. Just as significant, these years also saw the emergence of demands for representation within the $\mathrm{CS}$ so as to have a voice in policy-making and as a means of turning the EAP into a white man's country with all that implied in terms of economic and social policies.

Thus, the period 1902-1912 deserves study as a significant foundation period for the European dominance that later came to characterize colonial Kenya and has had such huge impact on that country's history. Just as important, these years witnessed the formation of the first political associations among the European settler community and the start of political agitation. The forms that these associations took as well as the type of political agitation and protest require careful study in this early period of colonial rule as many of the issues that featured then, such as single political parties led by wealthy and outspoken men and their political actions characterized by impunity and a lack of accountability, remain powerful factors in present-day Kenya politics. $\underline{\text { Research Objectives }}$

This study will examine the political demands made by the European leaders and the reaction of the $\mathrm{CS}$ and the $\mathrm{CO}$. The context of this analysis reflects Winston 
Churchill's famous description of his visit to the EAP in 1907. He noticed that there was an air of social stratification already blowing like a wind in the highlands of East Africa where race and color would be determinant in defining the political future of the protectorate. Churchill underlined it in his own words: "We mean to make East Africa a white man's country,' cries, in strident tones, the CA on every occasion. [This is] truly a respectable and impressive policy; but one which seems, at first sight, rather difficult to achieve... where there are... fewer than two thousand five hundred whites and more than four million black aboriginals."4 Churchill's observation of the evolving political scene led him to ask a pertinent question. He wanted to know if East Africa could ever become a country for the white settlers' convenience. He did not underestimate the fierce determination and dedication of the men on the spot who constantly pushed for more political concessions. He noticed that:

Every white man in Nairobi is a politician; and most of them are leaders of parties. One would scarcely believe it possible, that a center so new should be able to develop so many divergent and conflicting interests, or that a community so small should be able to give to each such vigorous and even vehement expression. There are already in miniature all the elements of keen political and racial discord, all the materiel for hot and acrimonious debate. The white man versus the black; the Indian versus both; the settlers as against the planter; the town contrasted with the country; the official class against the unofficial; the coast and the highlands; the railway administration and the protectorate generally; the King's African Rifles and the East Africa Protectorate Police; all

4 Winston S. Churchill, My African Journey (London: The Holland Association Press, 1962), 31. 
these different points of view, naturally arising, honestly adopted, tenaciously held, and not yet reconciled into any harmonious general conception confront the visitor in perplexing disarray. 5

Churchill's advice was not to side with any particular party in the evolving situation in East Africa. The settlers had no intention for cohabitation in a region where they were invited to partake in the process of economic development. From that perspective, the Europeans and their descendants believed that the other races must submit to them. ${ }^{6}$ The first officials who ran the protectorate also thought that any prospect of economic development had to rely on settler entrepreneurship and agricultural production. Such was the prevailing climate that existed between different interest groups in the early years of the protectorate, as epitomized in a 1907 address by the Pastoralists' Association stating that: "The evils the Colonial Office intended to prevent were already in existence: 'Monopoly, with all its abuses and dangers, is an acknowledge fact. The dummy system is a flourishing institution. Already there were signs that the Legislative Council is passing in its cradle days under the influence of one class of special interests. Already it does not pay the small man fearlessly to speak the truth in the public interest."7

In this atmosphere, there were some political organizations that emerged to articulate the settler demands (such as the Convention of Associations), and these will be a focus of study. These associations made persistent demands for political concessions. Some examples of the demands developed by the settlers include the

\footnotetext{
5 Ibid., 14.

${ }^{6}$ Brett L. Shadle, The Souls of White Folk: White Settlers in Kenya, 19oos-1920s (Manchester: Manchester University Press, 2015), 5 .

7 Address of the Pastoralists' Association, enclosure in Sadler to Elgin, 9 December 1907, CO 533/33, cited in M. P. K. Sorrenson, Origins of Settlement in Kenya (Nairobi: Oxford University Press, 1968), 94.
} 
establishment of legislative and executive councils, the right to vote, no taxation without representation, an important voice in the development of policy directed towards the colony's African population, and minority rule. All of these demands will be examined in this study. These demands seemingly indicate the type of political system that the Europeans desired was one in which only whites have political rights and participate in the governance of the colony. Other racial groups were not to be included in the political system. They were subjects.

The dissertation will also examine how these demands were met by the CS and the British government. Also to be examined is the question of the degree to which European political demands actually inspired those of the Asians, Africans and Arabs in the early period of colonial rule. The dissertation will thus establish the reasons for the success or failure of the numerous European political demands. It will also consider the impact of the organizations and of their political protest during the respective times of the EAP and later Kenyan history.

It is clear from this that in the early history of the EAP, the political aspiration of the settlers was high. They strongly believed that self- government, if achieved, was the best way to go. They wanted to be in charge politically and economically without taking into consideration the majority of Africans and Asian workers already present in the protectorate. These newcomers were not simply ambitious by nature. They had powerful advocates and supporters among the colonial administration. They had the sympathy of Eliot and most of his successors who tried vigorously to transform the highlands of East Africa into a white man's country. 


\section{Background to the Study}

The desire of transforming the highlands into a white man's country was mainly based on economical reasons. Opening the protectorate for trade was vital for the British Government which had, since the early 1890 s, been planning to build a railroad as a strategic measure to secure its presence on the Upper Nile River. The EAP officially became a part of the British Empire on 1 June 1895. The decision to establish a protectorate over Uganda led the British government to realize the necessity of linking the east coast to the interior for a greater penetration and exploitation of resources. On 5 August 1896, the construction of the Uganda Railway started in Mombasa. The railroad marked the beginning of colonial conquest, justified on the basis of practicality and profitability. The building of the railway did not lead to profitability for the EAP. From 1895 until 1913, the colonial administration was forced to rely on annual grants-in-aid from the British government.

British conquest and interference in African societies was the logical consequence of the railway project. It also had an emotional justification. For those who believed that the Africans still needed protection against slave traders, a stronger British presence in Africa was quite understandable. Beside protection from the evils of enslavement, the civilizing mission found good ground in justifying the British presence in the region. Christianity was introduced inside East Africa to educate and turn the Africans away from their traditional beliefs. The advent of colonial rule reinforced and encouraged a greater propagation of the gospel. The missionaries set the stage for the westernization of East Africa by diffusing their culture and values. These were important vectors of 
social change for the so-called "lower races." When numbers of European settlers arrived in East Africa from 1902, they embraced the same attitude. ${ }^{8}$

Civilizing the non-white races, from the British perspective, was philosophically up-to-date in the beginning of the 1900s. John Atkinson Hobson (1858-1940), in his work Imperialism: A Study, justified his choice of the term "lower races" because of the prevailing Eurocentric interpretation of non-white cultures. Hobson argued that the non-whites brought under imperialist rule were at the mercy of European powers who promoted their economic interests under the blanket of civilizing missions and philanthropy at any cost. For Hobson:

The real issue is whether, and under what circumstances, it is justifiable for Western nations to compulsory government for the control and education in the art of industrial and political civilization of the inhabitants of tropical countries and other so-called lower races. Because Rhodesian mine-owners and Cuban sugar-growers stimulate the British or American Government to Imperialism by parading motives and results which do not really concern them, does not follow these motives under proper guidance are unsound, or that the results are undesirable. 9

However, he also admitted that the native races cannot be left alone; though he insisted upon the necessity of certain safeguards to avoid their exploitation for mercenary purposes. The British presence on the Upper Nile was not meant to protect de facto the Africans from exploitation, but rather to solidify Britain's grasp in that very strategic part of Africa. Their presence in East Africa was practical and tactical in order to keep other European powers from monopolizing trade.

To maintain British leadership and economic predominance, new markets and raw materials had to be found and seized by force, or through policy manipulation of the

${ }^{8}$ Shadle, The Souls of White Folk, 27-28.

9 J.A. Hobson, Imperialism: A Study (London: George Allen \& Unwin, 1902), 228. 
local people. For an empire that spanned the globe, pacification was considered a practical policy. The construction of the railway aided in the pacification of the interior and also facilitated the economic development of the interior. The line was completed on 20 December 1901. With the high cost of the project, the pressure to make the railroad pay for its investment rose.

Sorrenson's work pinpointed the high cost of the Uganda railway as a concern for some important British politicians. He noted that: "Chamberlain and those who accepted his idea of developing Britain's imperial estates expected private citizens to carry the burden of development."10 Any settlement that could reduce the financial burden of the British taxpayer was welcomed to justify the positive presence of the expanding empire. The railroad construction was considered as a public undertaking managed by a committee of experts in London. Sufficient investment became a burden because the capital costs were financed by British Treasury loans. There was disagreement about the sufficient budget allocation for building the line from Mombasa to Kisumu:

In August 1895, when a vote of £20,000 for preliminary expenses was requested, the estimated cost of the line was fixed at $£ 1,755,000$. A year later, when the Uganda Railway Bill was introduced, the cost was raised to $£ 3,000,000$. This sum was not nearly sufficient: in 1900 the Foreign Office had to ask for another $£$ 1,930,000 and in 1902 for a further $£ 600,000$. As the annual interest and sinking fund charges on these loans amounted to $£_{319,112}$ the Treasury was to insist on a

${ }^{10}$ Sorrenson, Origins, 76. 
more rigid supervision of the East Africa Protectorate finances and the disposal of land than was normally the case. ${ }^{11}$

With financial difficulties such as these, there was no time, energy or budget for any kind of regional conflict. The British expected revenues to cover the cost of the project once the trains started rolling. The question of profitability and economic prosperity became a priority for the Foreign Office (FO).

It was after the completion of the railroad that some British officials, like Eliot, decided to shape the economic and political future of the protectorate. Eliot "took the initiative in both formulating and executing a policy which had as its ideal the foundation of a white man's country." 12 That would affect all parties in a plural society that resulted from Eliot's invitation. Accommodating the settlers became a priority for him. It is important to understand that Eliot's intention in promoting and regulating the settlement process was due to the fact that the first British adventurers who stepped foot in the region saw an apparent under-population. The new strategy emerged under the name of the "land distribution" or "the local partition of interior Africa" for the benefit of any settlers. The settlers seemed already to have developed a pattern of behavior in which they thought that they could settle anywhere, as they did in New Zealand and South Africa; so why not in the "New Virgin Plains" of pre-colonial Kenya? In his book, Sir Charles Eliot stated that, "We have in East Africa the rare experience of dealing with a tabula rasa, an almost untouched and sparsely inhabited country, where we can do as we will, regulate immigration, and open or close the door as seems best."13

\footnotetext{
${ }^{11}$ Ibid., 20.

${ }_{12}$ M. P. K. Sorrenson, "Land Policy in Kenya 1895-1945," in History of East Africa, vol. 2 eds. Vincent Harlow, et al. (Oxford: Clarendon Press, 1965), 672.

13 Sir Charles Eliot, East Africa Protectorate (New York: Barnes \& Nobles, 1966), 103.
} 
Nevertheless, before Eliot's arrival in the protectorate, the idea of European settlement was not thought of as something to be encouraged. The first Europeans who carried out expeditions in the region did not think it possible or suitable for Europeans to settle down. There was a cloud of skepticism about the possibilities of being successful in the far interior. The early attempts at settlement during the Imperial British East Africa (IBEA) Company period resulted in great disappointment, before the railroad era. Some British citizens who attempted to settle in the highlands got discouraged. They packed and went back to their true native land in Europe. Sir Harry Johnston, an important explorer, linguist and colonial administrator, was among the early skeptics who did not believe that Europeans could adapt in the region easily. Johnston had long believed in the development of Africa in racial harmony, and so could speak of this land also as a possible "America of the Hindu."14 John Dawson Ainsworth, another important actor, further espoused the same attitude as Johnston.

With all the incertitude and speculations about a European future in the region, Indian peasants and traders were thought to be the best alternative for settlement. Just before the completion of the railroad, Ainsworth suggested the idea of introducing Punjabi cultivators to back up African agriculture. Ainsworth's view was to first develop agriculture in the region before any plan of European involvement in local economic development. On July 13, 1899, from his provincial headquarters, he wrote to acting commissoner C. Craufurd stating that "there would not be the same scope for European emigrants as is for Indians. For a large number of Europeans the country does not, at present, hold out sufficient inducements; naturally Europeans need to make more

${ }^{14}$ G. Bennett, "Settlers and politics in Kenya," in History of East Africa, vol. 2 eds., Vincent Harlow, et al (Oxford: Clarendon, 1965), 265. 
money than does a native of India." 15 Johnston saw the Indian alternative with a very positive eye, too. The Indian settlement proposal in the almost "vacant" highlands, if successful, would be the pillar foundation to encourage Europeans arrival and definitive takeover. Yet, such Indian experimentation in the highland was not well received by Sir Charles Eliot, who replaced Sir Arthur Hardinge as commissioner of the EAP on December 301900.

Following Eliot's arrival, the settlement proposal that was going to encourage Indian influx into the region changed. For Eliot, the best plan was to deal with the tabula rasa by encouraging European settlement in the highlands and redirecting Indians into the lowlands. Any other aliens or indigenous group must stay away from the activity zone of the railroad. The policy of exclusion took shape under Eliot's administration. The scheme was for people of European descent to have the best land for free, upon invitation, the Indian to be confined in the lowlands and the local people to accept the new socio-economic order. It was a clear scheme of segregation, discrimination and arrogance. In Eliot's plan of regulating immigration, Europeans could come and settle down as long as they were white and Christian like Lord Delamere, one of the most influential early settlers. Under that indirect requirement for settlement, immigrants came from South Africa. Most of them had to be placated because Eliot promised land to whites coming from South Africa; and so they came, armed with a spirit of adventure. The promise of getting free land in the highlands was too succulent to resist.

${ }_{15}$ Ainsworth to Crauford, 13 July 1899, quoted in Robert Maxon, John Ainsworth and the making of Kenya (Lanham: MD: University Press of America, 1980), 78. 
From Eliot's time, European settlement was the means used to encourage the economic development of the protectorate. The authorities on location in the EAP hoped to make the railroad pay for its cost by accommodating settlers in the best areas possible along the railroad. Some of the Europeans, guided by a spirit of opening a new frontier, wanted land wherever they thought was most convenient for them. Europeans, Australians, New Zealanders, and South Africans were informed about the prospect of enjoying a potential paradise in the EAP. Those invited to settle in the protectorate, were in one sense, unwanted people, during Britain's great industrial revolution of the nineteenth century. Some of the Europeans from South Africa were Boers who already had a reputation of being racist. This attitude, de entrada, stripped away all hope of future cohabitation between settlers and Kenyans, spawning a disaster waiting to happen. The socio-political upheaval caused by the influx of European settlers would later have its impact in Kenya's political history. The seed of injustice was sown when the Africans started to realize that they were losing their land. For instance, the Kikuyu community that was affected the most by that phenomenon of land grabbing later described the process as such:

When the Whitemen first came we did not understand that we were to be deprived of any of our land, nor that they had really come to stay. A small piece of land here and there was sold to a few of the first pioneers and to one or two Missions voluntarily by its owners in the time of the I.B.E.A. Company. When the British Government took over the administration of the country we still were unaware that our possession of our land would be questioned of challenged. Then from about the year 1902 increasing numbers of Whitemen arrived, and portions of our land began to be given out to them for farms, until large areas in Kyambu, Limoru, Kikuyu, Mbagathi, about Nairobi, and at Ruiru and beyond, had been disposed of in this way. These land were not bought from their Kikuyu owners, and any compensation they received (for land actually under cultivation only, and at an extremely small rate per acre) was quite inadequate. The Natives on them had either to become squatters (on what had been their own land) or 
else move off. Many of them to-day are squatters on up-country European estates and many have become wanders, moving from one estate to another. ${ }^{16}$

It was clear that from the beginning of European settlement in the EAP, the legitimacy of the process of land acquisition became a concern of the authorities in London.

The plan for the EAP was based on a "fair land policy" and legislation dictated by London. In the early settlement days, the British authorities, "very loyal to their Crown," managed to define and acquire land through their legislation. With that mind set, their legislation allowed them to have the right to consider, and strongly believe, that all land in the EAP, apart from the coastal areas, was to be for the Crown. White settlement received paramount consideration, which meant that land policy favorable to them had to be pushed before any African interests.

In the early EAP administration, the arrival of the European settlers left a considerable political and economic imprint. They vehemently tried to obtain representative government without inclusion of the others races that could just be taxed as subjects. John Lonsdale depicted it in this paragraph he wrote about the attitude and impact of the newcomers on the white highlands.

White settlement was both the baronial consolidation of conquest and the chief threat to the politics of control. If it could not have politically dependent but independently productive small farmers, the Colonial Office came round to the view that it must have big capitalists instead. Big capital would provide the state with a different but equally controllable answer to the nervous 'rhinoceros questions' of African rights in expanded production. It was 'no good trying to lay hold of Tropical Africa with naked fingers'. What was wanted was 'tireless engines, not weary men; cheap power, not cheap labour'. Capital was the axe with which to cut a path through political jungles as well as nature's. If only it could be

\footnotetext{
${ }^{16}$ Extract From a Memorandum presented to the Parliamentary Commission in November 1924 by Kikuyu (Native) Association in William McGregor Ross, Kenya From Within (London: Frank Cass and Company, Limited, 1968), 56.
} 
given room to exploit African land, then the state could 'regulate in full and intricate detail' the relations between capitalists and the few skilled workers they would need. And the colonial state was indeed a cartographer; maps were its image of order. They showed strategic bases and frontiers zones, they marked property and the absence of it. White settlement filled in dangerous spaces with roads, fields and boundary beacons. The imagery should not be underestimated, and the reality hoped for, contented black labour on quiet farms with mortgages, producing payloads for a railway with a sinking fund [that] was itself the image of the civilizing mission, the self-justifying myth of the state as well as its mirage of calm. ${ }^{17}$

Meanwhile in London, totally ignoring African rights pertaining to the delicate issue of land was a question of concern. For Eliot, however, the matter was simple. Europeans were not to be compared with any other group of people in the region. They were on top of the developing situation and in control of the terrain. This attitude inspired much of the European political activity described in this dissertation.

\section{$\underline{\text { Study Area }}$}

The arrival of the settlers caused a sudden transformation of the highlands when the early officials decided to open vast tracts of land for development. Generous subsidies were given to fortune seekers like Delamere for cattle ranching and cash crop production like sisal and coffee. The geographical characteristic and diverse climate of East Africa gave hope to a possible economic boost that would hopefully alleviate the burden on the Treasury from pouring more money into the protectorate. The new land must be opened for business. The highlands, situated perfectly in the central part of the EAP, were seemingly waiting for new owners to make them flourish. They were highly

\footnotetext{
${ }^{17}$ John Lonsdale, "The conquest state, 1895-1904," in A Modern History of Africa 1895-1980, ed. W. R. Ochieng', (Nairobi: Evans Brothers, 1980), 25.
} 
viewed as the ideal place for settlement. These highlands also stretch into the presentday nations of day nations of Tanzania and Uganda.

These spectacular elevations stem from the legacy of our planet reshaping itself through volcanic activities in the remote past. The mightiest highlands are the ones found in central Kenya, which is covered in the geographical context of this study. The eastern branch of the famous Rift Valley snakes its way throughout the highlands. Tectonic forces caused geologic movements that gave birth to the Rift Valley. Opposing parallel cliffs with various elevations, extending as far as the eyes can see, delimit the Rift Valley giving it a unique topography and climate that characterizes central Kenya:

Kenya is about as large as France, with an area of around 582,600 sq.km, or 225,000 sq. miles. Most of it is arid steppe, in some places virtual desert, usable only for extensive pastoralism by sparse populations. Not more than about 14 per cent, or 80 , ooo sq. km, is suitable for agriculture or more intensive grazing. This high potential land is concentrated in the south-western corner of the country, $400 \mathrm{~km}$ (250 miles) and more from the coast. It is enclosed by the $1,000 \mathrm{~mm}$ ( 20 inches) for at least seven years in every ten. This is the area of the Kenya highlands, split down the middle by the Rift Valley. It was the scene of the second and third phases of the colonial conquest. ${ }^{18}$ The region is one of natural beauty and the first Europeans who surveyed this land marveled at it. The highlands of central Kenya later became the stage of important political and social developments because, in the process of territorial expansion, land became very important. Land was a valuable source of income and a good way to have social and political prestige. Consequently, land ownership became critical in Kenya. The amazing topography of inland Kenya and its nearly temperate climate triggered a land rush for British citizens. It also attracted settlers coming from South Africa. British officers assigned to the EAP decided to accommodate their compatriots, who logically chose to settle on the best land. New towns developed with the consolidation of power in the protectorate. Nairobi became the most important town in the interior with the highest numbers of settlers.

${ }^{18}$ Ibid., 11. 
Nairobi was founded in 1899 and owed its expansion to the railway that connected it to Mombasa. It became an important center of political decisions that would shape not only the economic destiny of the protectorate, but also its political future. Nairobi became a politically active capital. Settlers arrived and voiced their demands for economic assistance and total political control. Nairobi provided all the services that one could expect from emerging colonial town embracing a capitalist system at the expense of the Africans who lost their land and rights to be politically involved in the administration of the protectorate. In the growing town of Nairobi, African and Indians were relegated to the worst areas. ${ }^{19}$

\section{$\underline{\text { Structure of the Dissertation }}$}

Following this introductory chapter, this study of European political activity during the 1902-1912 period will be roughly structured around the administrations of the British commissioners/governors appointed to administer the EAP. These were short but eventful as each of the administrations, beginning with that of Sir Charles Eliot, dealt with similar issues closely related to European settlement, such as land, labor, and the settlers' demands for a voice in administration of the protectorate. Nevertheless, each administrator approached his charge in differing ways and met with varied challenges in dealing with those and other issues.

This principle of organization has produced chapters of varying length for, as will be seen, all but one of these leaders served an incomplete term in charge. Thus chapter 2 focuses on Sir Charles Eliot's term in office that marked the start of European settlement and the initial European political activity and organization. The next chapter

\footnotetext{
19 Churchill, My African Journey, 32-33.
} 
focuses on the brief tenure of Sir Donald Stewart (1904-05) which was marked by the CO takeover of supervision of the EAP. Chapter 4 details European agitation during the turbulent administration of Sir James Hayes Sadler (1905-09) while the fifth chapter details the disastrous tenure of Sir Percy Girouard (1909-1912). The final chapter will provide a conclusion and perspective for the study.

\section{$\underline{\text { Review of Related Literature }}$}

In the EAP, the European settlers' quest for political dominance was inspired by the southern African-style minority self government that led to white supremacy in South Africa. It was clear that the political situation in South Africa translated into the political mind set of the settlers originating from the south. Their political aspirations were part of the settlement scheme started by Eliot. When Eliot gave the best lands to the settlers to develop, the stage was set for the guests to enter into the political arena of the protectorate's administration.

The newcomers started echoing their voices in the affairs of the protectorate and the way local officials responded did not always please London, who had to recall some of them. The formulation of policy was often very controversial. The political effect of the settlers' initial presence in the EAP has not been adequately examined. Today the critical primary documents of the communication between offices and officials in London and in the protectorate are available. The early political history of the EAP can now be reevaluated with tangible sources, which will be of great historical significance to the colonial and most recent history of the people of Kenya. ${ }^{20}$

\footnotetext{
${ }^{20}$ Among the most important primary sources are the files containing original correspondence between the $\mathrm{CO}$ and the EAP. These are found in the British National Archives in the CO 533 series. The files cited in this dissertation were consulted at the Syracuse University Library.
} 
A study of the settlers' political demands in the EAP will mainly be based on the $\mathrm{CO}$ archives that are now accessible. Few scholars who were interested in the early political stage of the protectorate have touched these. Despite that interest, there are not many specific studies that have made extensive use of $\mathrm{CO}$ records for the period delimiting this work. This is due to the fact that the primary sources were not available when most of the studies about the settlers' political demands were conducted. The economic history of the protectorate and its consequences seemed more worthy of attention in its own right. British policy in the EAP merited a more detailed study than had been attempted. Retracing the settlers' political demands and their consequences is intended to be a new pedestal for further work to build upon; and that is why it is important to cover the critical ten year period before the protectorate became a crown colony.

Among the most prominent published works relevant for this dissertation are from Marjorie Ruth Dilley and George Bennett. They pinpointed the relevance of the political climate of the protectorate as soon as the settlers started growing in numbers in the protectorate. Their work represented a great attempt with good intention to recapture the British policy in the EAP. In British Policy in Kenya Colony, Dilley recognized the difficulties she faced in backing up her research. ${ }^{21}$ Prior to the publication of her work, she affirmed that there was a certain amount of unpublished material which she used during the course of her study but which she was not permitted to cite. Her work was done in the early thirties when access to the colonial records was not yet allowed. Dilley recaptured the nature and spirit of the newcomers who saw

${ }^{21}$ M. R. Dilley, British Policy in Kenya Colony, (London: Frank Cass \& CO.LTD, 1966). 
themselves as frontiersmen entitled to lands and rights of their own. Dilley showed the key aspirations of the settlers, which was to acquire land, exploit it, obtain cheap labor, and indirectly impose a favorable political system for themselves without paying attention to the purpose and meaning of a protectorate. She shows that the term "protectorate" did not fully encompass the right of the Africans, Arabs and Indians. Her work would have been excellent if there was not a hold on the sources she needed to better express the political mindset of the officials who ran the protectorate.

The work of George Bennett, Kenya's pioneer political historian, on the same topic fell in the same category as Dilley's. ${ }^{22}$ More work has been done about the administration of the protectorate. A detailed analysis of the settlers' political demands has been overshadowed by the economic issues that the protectorate faced and also the question of land distribution and labor. Robert Maxon's work, mentioned earlier, recaptured the power struggle over the control of the protectorate.23 Maxon showed that the $\mathrm{CO}$ did not always exercise total control over the region due to the fact that, most often the wrong officials, but with impressive credentials, had been sent to the protectorate, but had no idea or did not care about the political consequences of their actions. His work benefited from the use of available sources, but covered the years 1912 - 1923. This period overlaps with this research that will start in 1902.

British Rule in Kenya by G.H. Mungeam covered the period of 1895 to $1912 .{ }^{24}$ His work retraced the experience of the men on the spot. Despite his emphasis on the importance of British policy formulation enforced by commissioners, governors and other officials in a chronological manner, his work is more of a biographical

${ }^{22}$ George Bennett, Kenya, A Political History, (Nairobi: Oxford University Press, 1963).

23 Maxon, Struggle for Kenya, 13.

24 Mungeam, British Rule. 
compilation than a deep insight into the political climate that existed between interested parties in the protectorate. Mungeam pointed out that British rule interfered with the African way of life and marked a beginning of change, but he did not develop the primary reasons for that mutation. Change had been triggered by the British presence in the region and had been accentuated by Eliot's invitation extended to European settlers who were coming mainly from South Africa. As soon as they grew in number, they felt the need to organize themselves. However, Mungeam's book does not make settler politics its main focus, and neither does Origins of European Settlement in Kenya, by Sorrenson.

Nevertheless, Sorrenson underscored how the problem of land distribution triggered the tension between the $\mathrm{CO}$ and the settlers. Massive land alienation for white settlement gave birth to political aspirations for a potential control of the protectorate. That meant gearing towards self-government. His work shows the concerns of the $\mathrm{CO}$ about the economic and political future of the protectorate. He focused more on the origins of land appropriation and the redefinition of the idea of pushing the frontier for settlement and its consequences. Settlers came from South Africa, and the CO that assumed responsibility for the EAP in April 1905 had to monitor them by formulating the right policy from the East African Department. Sorrenson did not make the settlers' political demands that followed settlement the main argument of his work.

The origins of settlement had a direct connection with the question of occupation without taking full consideration of the African rights. The protectorate could become a country carved for white settlement, catering to their needs. Sorrenson considered arbitrary land grabbing at the expense of the African as a developing problem that could degenerate into a conflict in the region between newcomers and Africans. The idea of 
establishing a white man's country was on the horizon in the early administration of the protectorate. The work of some Europeans who also came as settlers flirted with the idea of a white man's country in the making.

E. Huxley's most prominent work valued the entrepreneurial character of settlers like Delamere. ${ }^{25}$ Studies of the political changes due to settlers' influence had not been extensive and objective at all. Nevertheless, a two volume biography of the most influential political leader among the settlers was written by Huxley. She introduced Delamere as a model among the settlers. She considered the presence of the settlers as beneficial for the protectorate. Huxley could be considered as a woman of her time whose parents came to seek fortune as well in the EAP. Her first book was a reflection of how some settlers like Delamere saw themselves in the early years of the EAP. Lord Delemere (Hugh Cholmondely, 1870- 1931) was a fortune seeker and pioneer before he decided to permanently settle in Kenya. He was a farmer and an active politician representing the settlers' community. He loved hunting, land and power. He almost achieved all under the watch of weak officials who sympathized with his ideas. The success of Delamere was what most settlers were seeking. Huxley's work praised the achievements of Delamere, who rubbed shoulders with important officials and almost all the governors sent to the protectorate. He used his reputation and charisma to influence the policy making of the protectorate for the benefit of the settlers. The settlers organized themselves around him. Huxley's book about Delamere was published in 1935, and paradoxically, a similar definitive work about another influential and eccentric settler was published long after the demise of the British Empire.

25 E. Huxley, White Man's Country- Lord Delamere and the Making of Kenya (New York: Macmillan 1935). 
Delamere was not the only settler with a high desire of success and adventure. Ewart Scott Grogan (1873-1967) was another flamboyant settler and adventurer who fell in love with the exotic character of Africa through readings while growing up in London. In 1896, he traveled from Capetown to Cairo. He arrived in the EAP in 1903, and rode the wave of settler support. He became the president of the Colonists' Association (CA) and then the Convention of Associations (C of A). Grogan served in the Legislative Council (Legco), and was not shy in confronting the colonial officials in Nairobi or even the British government itself. Nine decades after Grogan's arrival in the protectorate and thirty-four years after his death, Edward Paice paid him a tribute by writing his biography. ${ }^{26}$ Paice portrayed him as a formidable adventurer, risk-taker and go-getter, despite the fact that Grogan advocated European political supremacy in the protectorate. Paice's work followed the same line as Huxley's book about Delamere. The biography of the settler leaders like Delamere and Grogan were mostly based on secondhand information written by admirers of the adventurers. What makes Paice's work important is that it brings back the context in which policy was formulated in the EAP, and the people who at that time were involved and the consequences that defined the political future of the region.

There is no doubt that biographical works about the newcomers in the EAP have been extensive; but again, they rarely retraced objectively the real political aspirations of the settlers. Most of these works did not use viable primary sources. Huxley and Paice never had the opportunity to interview the leaders of the settlers' political movement. Their works glorified the determination of the daring settlers who truly believed in the

${ }^{26}$ Edward Paice, Lost Lion of Empire (London: Harper Collins, 2001). 
idea of transforming the political economy of the EAP and obtaining self-government.

There were contradictions between what the settlers wanted and what the $\mathrm{CO}$ was being briefed. Reports of the political development of the protectorate to London did not reflect the true reality of how policy was being formulated by the men on the spot. There were favoritism and a laissez-faire attitude triggered by the tremendous pressures that the settlers' associations exercised on almost all the governors who were sent to administer the protectorate.

Bruce Berman captured the contradictions of policy within the CS when the settlers arrived and tried to survive and prosper in a new social, economic and political environment. In Control and Crisis in Colonial Kenya,27 Berman used extensive primary sources, including numerous interviews with Kenyan and British participants to show these contradictions and their consequences. As Richard Waller pointed out in a review:

Professor Berman argues that the colonial state was shaped by the contradictions between maintaining effective political control with limited coercive force and ensuring the profitable articulation of metropolitan and settler capitalism with African societies. This dialectic of domination resulted in both the uneven transformation of indigenous societies and in the reconstruction of administrative control in the inter-war period. The study traces the evolution of the colonial state from its skeletal beginnings in the 1890 s to the complex bureaucracy of the post-1945 era which managed the growing integration of the colony with international capital. These contradictions led to the political crisis of the Mau Mau emergency in 1952 and to the undermining of the colonial state. ${ }^{28}$

Berman's work benefited more from the availability of extant archives than some earlier works did. Nevertheless, other important works from people who

27 Bruce Berman, Control and Crisis in Colonial Kenya (Athens: Ohio University Press, 1990). ${ }_{28}$ Richard Waller, "Kenya's Contradictions: Control and Crisis in Colonial Kenya: The Dialectic of Domination," Journal of African History, 34 (1993): 155-156. 
witnessed the early political development of the protectorate should also be considered as relevant, but not fully satisfactory. It is complex to really know the motives that prompt them to denounce the way the protectorate was run by most of officials sent by London. The poignant records of a medical officer like Norman Leys, and also an official like McGregor Ross in the British administration in East Africa, ideally reflected the results of the impact of British colonialism on traditional African life. Norman Leys and William McGregor Ross witnessed the political development of the EAP and wrote about it.

The publication of Kenya by Leys was a critique of the interference caused by the new system established in the EAP. ${ }^{29}$ The British presence in East Africa brought change that led to a collision of cultures. Leys' work was an effort to denounce injustices and mismanaged capitalism and its impact on Africa and Africans. Leys' book was a radiant critique of European imperialism, contrary to many officials and settlers who thought that there was little worth preserving in Africa's traditional social fabric that they viewed as "primitive." As the society changed with the arrival of the Europeans, the political affairs of the protectorate became more and more a concern for the $\mathrm{CO}$ and humanitarians like Leys. There was favoritism encouraged by the men on the spot due to the settlers' constant push for more political concessions. Starting from Commissioner Eliot, all the governors that followed in administrating the protectorate fell under the pressure of the settlers who wanted more representatives in the Legco. Leys comments on these developments:

Nominally the governor, who can dispose of an official majority in his councils, is under the control of the Colonial Secretary, who in turn is responsible to

\footnotetext{
29 Norman Leys, Kenya (London: Frank Cass and Company Limited, 1924).
} 
Parliament. Actually the influence of the European colonists has hitherto been decisive of events. Governors are frequently referred to in public as the colonists' defenders against the Colonial Office, and most recently, governors have acquiesced in such a conception of their position. The passage of the Duke of Devonshire's dispatch, in which he dismisses the proposal of responsible government, is not taken seriously by the European Colony, but is regarded as one of those merely formal statements whereby humanitarian sentiment in England is satisfied. 30

The Devonshire dispatch was a huge political blow for the settlers. Partisan politics was obvious in the protectorate and Leys denounced it in his work. He blamed the officials who sympathized with the settlers, who were a numerical minority, and the last to arrive in the protectorate. The newcomers wanted to be served first. That itself created concerns in London and also among some humanitarians like Leys himself. The problem with Leys' work as being critical by directly pointing a finger at the officials formulating policy that benefited European settlers, and undermining the Africans' rights, is that Leys' political ideology was not sympathetic to the extreme capitalist system being set up in the EAP. Leys, therefore, was viewed as an unsentimental socialist who thought of the British rule of Africans as an unnatural monstrosity, a well packaged system that tagged capitalism at its worst. Leys' work is often classified as belonging to the less sentimental groups of white critics of British imperialism. His work was geared toward the defense of African rights in the face of the evils of capitalism and extreme European interference that was a threat to traditional African societal settings.

Keeping up with political developments in Kenya became so captivating that Ross decided to keep track of it. He kept his records straight and wrote about Kenya. The publication of Kenya from Within in 1927 was an immense effort that tried to keep

30 Ibid., 377. 
track of the political developments in the protectorate. ${ }^{31}$ Ross, while in the service of the British Government, kept a dairy of all the political developments that were transforming the protectorate and its mixed population. Ross acknowledged the difficulties of his task while attempting to record the political transformation of the protectorate. He stated that: "It is only to be expected that this book suffers, in places from faults inherent in accounts of heated political happenings written by one who played parts, varying from inconspicuous to prominent, in some of them, and who took a lively interest in them all." 32 Ross admitted that he tried to be accurate, and he modestly opened the door for any correction by any who might discover inaccuracy later on. Ross' work had a great significance because it pointed out the direction to follow to properly understand the struggle within the protectorate among all parties involved. Ross' major deficiency was the unavailability of primary sources to back up his research. The most recent work relevant to this study is Brett Shadle's The Souls of White Folk: White Settlement in Kenya, 190os-1920s. Shadle provides a detailed account of the early social history relating to Kenya's settlers, including their views on their lives and experiences in the highlands. His conclusion that "White settlement was based on the equation of civilization with (a difficult to define) whiteness was emotionally enriched through notions of paternalism and trusteeship; appeared consistently under threat from Africans, colonial administration, judiciary, and fellow settlers; and was shored up daily through rituals of prestige, difference, humiliation, and violence" is important in providing and understanding for the attitudes adopted by European

${ }^{31}$ William McGregor Ross, Kenya from within, (London: Frank Cass and Company Limited, 1968) $3^{2}$ Ibid., 6. 
migrants.33 While Shadle's book sheds much light on the attitudes of Kenya's early settlers, the book gives little attention to politics and political organizations.

\section{$\underline{\text { Conclusion }}$}

This chapter presents a case for a need to reevaluate the political history of the EAP between 1902 and 1912. The challenge here is to chronologically follow the settlers' political demands in the EAP according to each administration. This work will analyze the political demands of the European settlers, starting from Eliot's time in the protectorate (1900-1904), being the first commissioner sacked by the $\mathrm{CO}$, through that of Sir Percy Girouard, who also was sacked in 1912. The administrations of these two officials, who formulated policy that deliberately facilitated the interest of the settlers, provide the purpose of this work. The political arena of the protectorate, and what politically happened on that stage, per se, is worthy of re-enactment, taking into account the availability of the original nature of all the communication between Nairobi and London. It is well known that there were dispatches sent by the $\mathrm{CO}$ to intervene and readdress the political destiny of the protectorate. Some of them brought news of top officials who were supposed to run the protectorate fairly and effectively, as being recalled. The political stage looked like a political fiasco because there was no room or will for a political co-habitation that would welcome all the people in the so-called "protectorate." Commissioners and governors sent to the protectorate during the decade under study did not last long.

They did not administer the protectorate in a satisfactory manner that would have benefited all the people then present in the region. Navigating through the $\mathrm{CO}$

33 Shadle, The Souls of White Folk, 4. 
records will finally help to reopen and reevaluate the early political history of the EAP, with the European settlers as the main focus. They tried in vain to achieve self government in East Africa, which they thought would be an exclusive white man's country. As most of the works mentioned in the literature review did not use the $\mathrm{CO}$ records to shed light on the settlers' political aspirations, this work seeks to chronologically re-navigate the critical political history of the EAP according to the successive line of British officials and their failed policies for an evolving melting pot of society. The settlers' growing political influence and extreme aspirations raised fundamental moral and political issues concerning the existence of a timetable to fully implement African rights in the protectorate.

The settlers' pursuit of happiness, prosperity and full political rights turned the protectorate into a subject of national debate in the British parliament. The rights of the Africans, who supposedly needed "civilization," were ignored by important officials like Eliot. The political developments following the building of the railroad and European settlement are worthy of a detailed study in order to understand the notion of empire and interference in what is often called the "Dark Continent" or "white man's country," specifically in the early days of the protectorate. 


\section{Chapter 2}

\section{An Open Invitation to some Conflictive British Outlanders into the EAP: A Social and Political Struggle in the Making}

\section{Introduction}

The arrival and settlement of people of European descent in the EAP in the early twentieth century was mainly the work of Commissioner Sir Charles Eliot. He promised land to settlers who were willing to come and help develop the region. Settlers from South Africa took the lead and others came from Great Britain, Australia, New Zealand and other British colonies. The commissioner did all that he could to attract settlers from different classes and backgrounds. There were aristocrats, business adventurers, small and big farmers, Anglo-Boer war veterans and land speculators. W.S. Churchill, who visited the EAP in 1907, took particular notice of them, describing the whole lot as typical "political animals". 34 The then under secretary for the colonies' remark meant that the European newcomers were not just actively engaged in politics; but they were at the same time big trouble makers, very demanding and difficult to please. Their presence and political ambition in this new British dependency signaled the beginning of an era of ambiguous and contradictory policy formulations that solely benefited them. The new situation became a mounting problem for the powers in London. That way of doing politics by leaving the majority population behind did not last forever, but it left an enduring legacy in Kenya's political history.

The influx of European settlers brought a new socio-political dynamic to the protectorate. With the commissioner on their side, they tried to define, develop and defend their interests. The settlers saw the need to form political parties, a key

34 Winston S. Churchill, My African Journey (London: The Holland Association Press, 1962), 31. 
instrument for the acquisition and exercise of state power in a British colony. They sought to use party politics to achieve their group and personal interests. The future terminus of their political ambition was the attainment of self-government on the model of South Africa. In other words, they progressively wanted total political control of the protectorate. Their demands sparked a struggle between differing, competing and often antagonistic interests. The rights of both the Africans and the Indians, who came before the European settlers, were to be taken into account by the FO.

Nevertheless, under the supervision of the FO and the eye of British humanitarians and the India Office, Eliot simply did not have all the power in his hands to formulate policies solely benefiting his preferred settlers. Settlers' political demands were not totally accepted by the FO, which sent the commissioner to administrate the protectorate. Despite this limitation of power, he started formulating policy that he thought was the best for the protectorate. Eliot's failure to listen and report to the FO officials in London about the question of his arbitrary land allocations to some settlers led to his dismissal. However, it remained manifest that the impact of his administration triggered a political contagion dominated by settlers' demands that successive governors sent to make the protectorate profitable had to wrestle with. The political struggle of the settlers was not yet over with the sacking of Eliot. In fact, the settlers geared their political parties to channel their demands in order to protect their interests and increase their power. Eliot just set the tone and left. 
Sir Charles Eliot: The progenitor of European settlement in the EAP

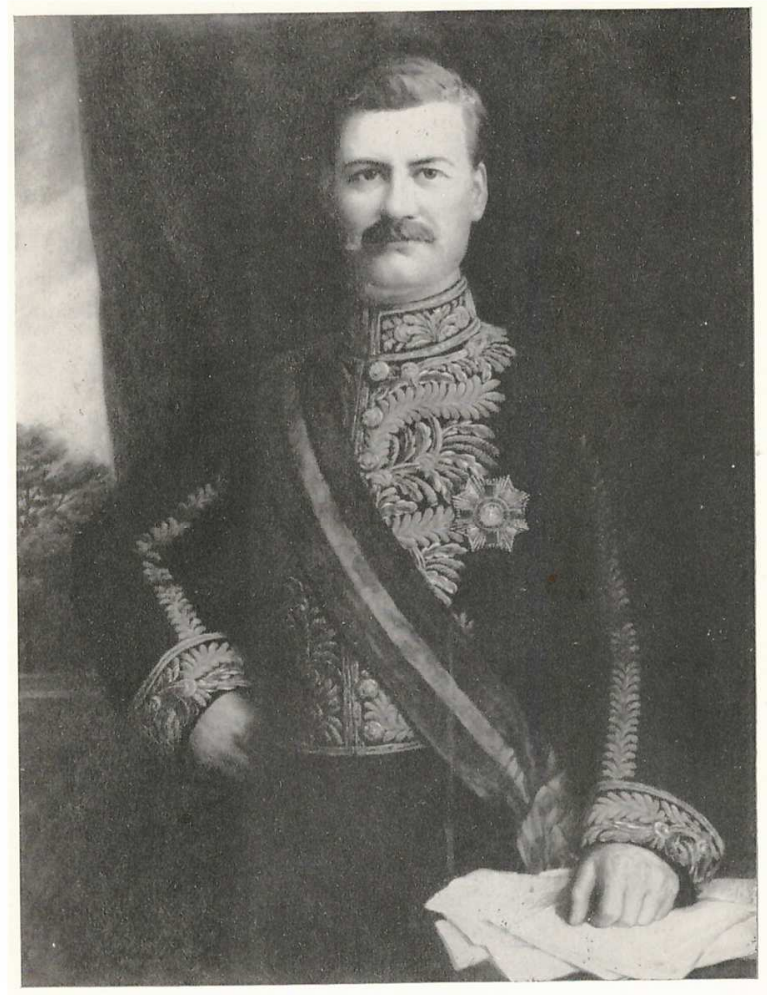

Sir Charles Eliot

Image 1: Sir Charles Eliot. Source: Mungeam, British Rule, 70.
In December 1900, Sir Charles

Eliot succeeded Sir Arthur Hardinge as Commissioner of the EAP. In February 1901, he arrived in the EAP. He was also responsible, as the Consul-General, for the administration of Zanzibar, an island off the coast of East Africa. He was a career diplomat who had served in the United States of America, Russia, and the Near East. He thus had international experience that could potentially help him administrate the EAP. That was the main reason why the FO sought him out

as a replacement for Sir Arthur Hardinge. The new commissioner was well educated and charismatic. Eliot projected an image of being the right man on the spot, ready to defend British interests in East Africa.

Most of his contemporaries thought quite highly of him, esteeming Eliot as one of the most able men for the administration of the protectorate. As nice as the first accolades from the officials in the protectorate were, Eliot was not the most affable diplomat. Within a few months of his arrival, he complained that so far his subordinates had acted '“much as Consuls act in the Levant', merely confining their duties to hearing complaints, redressing grievances and writing reports. They had done little to 
administer or develop the country." 35 Unlike these officials, the second commissioner displayed the zeal of a pragmatic administrator in his objectives to change the economic direction of the protectorate.

However, Eliot did not receive any specific instructions to prepare him for the work of mainland administration. He took initiatives to run the protectorate the way he thought was the best without seeking extensive guidance from the FO. Eliot was very confident with his plan to bring positive changes in the protectorate. The commissioner made suggestions for improving administration and investigating the commercial possibilities of the country. The FO listened enthusiastically to him as he made his first moves towards developing the protectorate. In addition he had gained "a most favourable impression' of the prospects for European colonization in the highlands." 36

It was apparent that the commissioner seemed to have fostered a hidden political agenda, one that favored the European settlers above all others, like in South Africa. He had a vision of transforming the highlands of the protectorate into a white man's country. Eliot argued "the interior of the Protectorate is a white man's country.... It is mere hypocrisy not to admit that white interest must be paramount, and that the main object of our policy and legislation should be to found a white colony." 37 Eliot did not have to look far to find a model of success for European settlement in Africa. As the European emigration to South Africa proved to be successful, Eliot decided to adopt the same strategy to create a white man's country in East Africa. He strongly believed that

\footnotetext{
35 Eliot to Cranborne, 15 May 1901, FO. 2/447.

${ }^{36}$ Sir Charles Eliot, East Africa Protectorate (New York: Barnes \& Nobles, 1966), 103.

37 Ibid.
} 
the opening of the protectorate could give an avenue to European settlers who could later reproduce the South African model of self- government.

The commissioner's energetic approach resembled those of the former autocratic governor of the Cape Colony, Lord Charles Somerset (1814-26), who in his intention of transforming that colony into a prosperous British holding declared that:

Settlers possessing sufficient means were encouraged to engage at least ten ablebodied individuals in agricultural pursuits rather than in the maintenance of large herds of cattle, thus forming a cordon of close settlement against the inroads of savage life. On 100-acre allotments for each adult male emigrant 'in most healthy and temperate climate in the universe,' distressed labourer and aspiring lord would come together in the re-creation of their vision of English landed society. Free from 'contamination of slavery,' independent of native labour, and based on 'mixed body of agriculturalists and mechanics,' gentry and laborer would 'reciprocally create and remove wants, and thus stimulate each other' to increased productivity, social order, and social cohesion. ${ }^{8}$ Eliot embraced Somerset's idealism and strategy. There was no need to reinvent the wheel. The formula was simple; it consisted on the paramountcy of the settler's right to dominate the socio-economic and political fabric of the protectorate. He had to pave the way for the settlers whom he believed would be the pillar foundation for his plan to develop and eventually run the protectorate. His first step was to brief the FO about the potentialities of the region. He informed the Foreign Secretary, Lord Lansdowne, that peace, stability and the advent of the railroad had transformed the EAP, which must be opened for business to generate revenue to balance the annual protectorate budgets.

$3^{8}$ J. Reader, Africa: A Biography of the Continent (New York: Alfred A. Knopf, Inc, 1998), 465. 
Eliot's vision was to turn the protectorate into a profitable and well-administrated crown colony. On 5 March 1901, he enthusiastically expressed the situation to Lansdowne stating that:

I do not think you quite realise at home what an immense change has come over the East Africa Protectorate in the last few years. About 1895 East Africa was still what it purports to be -a Protectorate superintended by Consular officers. . . . In the last few years all this has been suddenly change by two events, the suppression of the Mazrui rebellion and the building of the Uganda Railway. The former broke the power and influence of the Arabs, the latter opened up a new country in which no one could pretend that British officials were Consuls supervising a local administration. The consequence is that the country has unconsciously grown from a Consular District into a Colony.... I felt-as every official out here must feel -as if I were administering a Crown Colony or an Indian Province. Unfortunately the Administration has not changed with the condition of the country; it is still organised on an old Consular theory; it still leaves undone the things which Consuls do not do but which people who are practically, if not theoretically, an independent Government ought to do. 39 Eliot's letter to Lansdowne suggested that the FO and the people of England had

no substantial information about the potentialities of the region. According to him the main obstacles hindering development were the passivity of the British officials in the protectorate and their lack of vision. Eliot vowed to rigorously administrate the region like a full grown crown colony. Although Eliot gave an exaggerated and negative evaluation of how the protectorate was administrated to Lansdowne, he progressively made it his business to work on opening the door to the European expatriates. By 15 May 1901 he had visited the interior, he went on to describe the protectorate as if it was an el dorado consisting of a "large area of highland with a cool and invigorating climate, fertile soil and wide pasture grounds.' which he believed to be suitable for European

\footnotetext{
39 Eliot to Lansdowne, Private, 5 March 1901, as quoted in G. H. Mungeam, British Rule in Kenya 1895 1912 (Oxford: Clarendon Press, 1966), 76.
} 
colonization."40 Eliot officially manifested his inner desire to incorporate European settlers in the region ipso facto.

\section{Eliot's Plan to introduce European Settlers}

The idea of bringing European settlers into the protectorate was not new to the FO. Before Eliot's arrival, only a few Europeans were able to settle in the interior of the protectorate. It was deemed precarious to remain isolated in the middle of the country, surrounded by Africans without British protection. James McQueen, a blacksmith, immigrated there in 1896. T.A Wood also settled in, and even opened a hotel in 1900, just when Nairobi was in the process of becoming the center city of the protectorate. Wood's hotel later became the ideal meeting place for the Europeans who came in after the completion of the railway. Social gatherings at Wood's hotel set the stage for the settlers' future political claims and aspirations. ${ }^{41}$ The quasi-inexistence of a great number of European settlers in the interior was not a problem. The FO could keep on relying on Indian labor. After all, they helped to build the railroad and develop trade in the region. They were good traders and the Africans knew who they were. Some British officials and other European settlers, who were aware of the presence and value of the Indians, entertained the idea of encouraging them to permanently settle in the protectorate. They noticed that the Indians could cohabitate peacefully with the Africans

\footnotetext{
$4^{\circ}$ Eliot to Lansdowne, private, 15 May 1901 as quoted by Mungeam, British Rule, 77. Sir Harry Johnston first believed in the development of Africa in racial harmony and went on to express his hope of a possible cohabitation including the Indians. He later changed his mind and bought into the idea of the necessity to rely on European settlers to boost the economy of the protectorate. The arrival of the charismatic commissioner had a lot to do with Johnston's flip-flop. At that point in time, the Foreign Office concern to reduce the protectorate grant-in-aid opted for both European and Indian settlement. Eliot put his trust on the former and worked diligently to convince London with his discriminatory economic immigration plan.

${ }^{41}$ See related account in G. Bennett, "Settlers and Politics in Kenya," in History of East Africa Vol. 2, eds. Vincent Harlow, et al (Oxford: Clarendon, 1965), 266.
} 
and help develop the protectorate. In fact they were doing that long before Eliot took charge of the protectorate.

John Ainsworth, ${ }^{2}$ an experienced official who knew well the protectorate, advised the FO to encourage Indian settlement. Ainsworth served the protectorate well holding various positions from 1895 up to 1917 . He was sub-commissioner and later provincial commissioner of Ukamba, Naivasha and Nyanza provinces. He was very familiar with the issue of African land rights and also acknowledged the important contributions of the Indians in the region. Even before Eliot took charge of the protectorate, Ainsworth noticed the importance of having the Indians in the region and advised the FO to push for their permanent settlement. "There would not be the same scope for European emigrants [sic] as there is for Indians.... For a large number of Europeans the Country does not at present hold out sufficient inducements; naturally Europeans require to make more money than does a native of India,"43 he asserted. Ainsworth knew that the Indians integrated well and developed trade and could play a significant role in improving the Kamba agricultural system. European settlement also drew more skepticism from other officials like Sir Harry H. Johnston, Special Commissioner for Uganda. In 1899, he wrote that "East Africa was unsuitable for European settlement but that in time there would be a great overflow of India into these insufficiently inhabited, uncultivated parts of East Africa now ruled by Britain and

42John Ainsworth's career is fully described by Robert Maxon in his detailed work titled: John Ainsworth and the making of Kenya (Lanham, MD: University Press of America, 1980). Ainsworth dedicated himself to the need to defend the Africans and the Indians rights in the protectorate at the time when the presence, influence and power of the European settlers were increasing because of a deliberate policy of favoritism sparked by Eliot who encouraged them to come develop the region.

43Ainsworth to Crauford, 13 July 1899, as quoted in Maxon, John Ainsworth and the making of Kenya. 92. 
Germany." 44 Johnston held the idea that a progressive incorporation of Indians would activate trade and agriculture for the development of the protectorate. Indians could live without quarreling with Africans. There was more evidence that Indians were efficient and peaceful workers. The construction of the railway was the blueprint of their labor contribution and trade was their entrepreneurial endeavor. Unfortunately, Eliot came to change that dynamic. He is credited with having initiated the policy of white supremacy in the British East Africa Protectorate.

Eliot did not have to wrestle with the question of introducing European settlers in the protectorate. For him the answer to a stagnant economy was a considerable influx of desirable capitalists who would be accommodated in the highlands. There was no need for speculation on the part of the charismatic career diplomat. The measure was simple for him. Eliot truly believed that he had the key for a positive socio-economic change in the EAP. According to the man on the spot, Indians should be confined in the lowlands and Africans dispossessed of their land, used as laborers for the new invaders and taxed to generate revenue. The commissioner had come to the conclusion that the main issue the protectorate was facing was the completion of the railway and its economic implication. It was crucial to make it pay. For that to happen it was necessary to start collecting taxes from the local population. In addition to that proposal the commissioner highlighted that the protectorate offered a "large area of highland with a cool and invigorating climate, fertile soil and wide pasture grounds." 45 The commissioner's correspondences with the FO revealed the character of a diplomat who, from the early months of his administration, decided to have no mercy or consideration

44 Sir Harry H. Johnston, Colonization of Africa by Alien Races (Cambridge: University Press, 1899), 281. 45 Ibid. 
for the Africans, regardless of their economic situation. Also, Eliot took a stand in firmly believing that the highlands were the ideal ground for European settlement.

The man on the spot was already proceeding quickly, envisioning the highlands to soon turn into many white settlers' new destination and country. Lansdowne expressed some criticisms about the levying of a hut tax suggested by Eliot. It almost became a moral dilemma for London to enforce a taxation system from a "poverty stricken peasantry with a backward agriculture." 46 The Africans in the protectorate were just starting to recover from natural calamities they suffered a decade before Eliot arrived. There was not enough land to support land-hungry migrants even though the region seemed apparently under populated. The paucity in the Kikuyu region, mainly along the railway, was due to natural disasters. The famine and smallpox epidemic of 1898-99 ravaged the local population. Eliot was not an exception among the intellectuals who drank from the cup of social Darwinism. Africans, who might perish under any circumstances, were the ones who were not fit enough to continue in the protectorate. Eliot had only a vague idea of the interior of the protectorate but kept trying to convince the FO of the need to encourage European settlement. Of course, the FO had no exact, defined policy of developing the protectorate. Incorporating and integrating European settlers was not going to be simple if the best land was going to be arbitrarily alienated for the newcomers at the expense of the Africans.

Nevertheless, the commissioner negotiated his case for European settlement with the FO. As there was no concrete plan from the FO to develop the protectorate, Eliot's proposal then started to take shape. He planted an idea in the officials' minds in

46 C. C. Wrigley, "Kenya: The Pattern of Economic Life 1902-45," in History of East Africa, vol. 2, eds. Vincent Harlow, et al. (Oxford: Clarendon Press, 1965), 211-14. 
London that something had to be done and something like his plan was better than no plan at all. After all, in capitalism risks must be taken to generate revenue. It should be a well-calculated risk. In the case of the EAP, Eliot took an unfair calculated risk because it tended to undermine the incorporation and integration of Indians and Africans in the new system of production. Eliot's plan for the protectorate was the development and growth of a ruthless form of capitalism best illustrated in South Africa, solely based on European settlers' production. He envisioned the European settlement as his best choice to justify the theory of the fittest individuals in society whom in practice would benefit from his guidance and make the protectorate profitable. His plan was to accommodate a "superior race," the white man's race in the protectorate, and gave them unlimited support to help exploit the region for the benefit of the British Empire. This was the agenda of a typical unethical rationale for a laissez-faire capitalism. "Sir Charles Eliot predicted that if his advice to found a European colony was followed the country would pay its way, certainly in ten years, perhaps less," 47 Dr. Norman Leys asserted. That was a bold prediction, but it was surely comforting for the FO to see Eliot's optimism. Yet, the FO did not know about the dark intentions of the well-trusted commissioner to favor the settlers only and the future political consequences of such a policy. Lansdowne ordered him to proceed with care, mainly with the question of land and taxation vis a vis the Africans..$^{48}$

New Rules under Eliot

When Eliot came up with the idea of taxing the Africans as part of his solution to generate money for the financially stressed protectorate, Sir Clement Lloyd Hill, the

47Norman Leys, Kenya, (London: Frank Cass and Company limited, 1924), 158.

${ }^{48}$ Lansdowne to Eliot, 27 August 1901, FO 2/443. 
Superintendent of the African Protectorate Department (APD) at the FO, revised Eliot's proposal for taxation and noticed that the success of any plan to administrate the protectorate depended on finance, but somehow he agreed with Eliot's suggestion. He informed Lansdowne on the matter. Lansdowne responded with the following minute arguing that: "For the present the problem seems to be how to tap the undoubted resources of the country without assuming too many of the responsibilities of administration." 49 What Lansdowne did not know was that Eliot was on the way to assuming more responsibilities; he was paving a way for the settlers. He started updating the FO with reports about the prospects for the protectorate.

In June 1901 he dispatched his first annual report, again underlining the great potential of the protectorate suitable for European colonization. He pushed hard to seduce the FO about the exotic nature of the well-watered protectorate with its comfortable climate that European settlers would find ideal.50 According to Eliot, the protectorate was a vast no-man's land that could be transformed by the fittest European settlers. At no time were the Africans or the Indians part of his scheme to resolve the financial equation of the EAP. In his second annual report, he reiterated his strong belief of having encountered the perfect land for his upcoming discriminatory policy that was to take place once the FO took up his plan to bring in the European settlers. The commissioner exaggerated his description of the protectorate. In his view, as described by Sorrenson: The Kikuyu country had a native population unusually dense for East Africa but claimed it was not too dense to prevent European settlement. "He

49Minute by Lansdowne, no date, on Eliot to Lansdowne, Private, 15 May1901, F.O 2/447.

$5^{\circ}$ Brett L. Shadle, The Souls of White Folk: White Settlers in Kenya, 19oos-1920s (Manchester:

Manchester University Press, 2015), 13. 
went on to describe the Kikuyu country as 'one of the richest and most promising districts in the Protectorate.' Njoro in the Rift Valley was considered as 'one of the most favoured' districts, with scenery 'strikingly English.' The Nandi country was described as 'perhaps the most beautiful district in the Protectorate." ${ }^{1}$

The commissioner drew a similitude of the protectorate with other British colonies like Australia and New Zealand to make his case before the FO. Under Eliot's eyes, the EAP was not different from those countries that welcomed European settlers, but his comparison was not accurate. Australia and New Zealand offered more land suitable for European settlement. Land was more available in both Australia and New Zealand, which were less populated than the EAP. Still for Lansdowne, full control of the protectorate had to be secured first. That meant that money had to be channeled for military and police measures not for administrative concerns. The confident commissioner promised that he could make the protectorate profitable if fully trusted with his plan to secure more revenue. Eliot's dedication to carry on with his scheme paid off when Lansdowne agreed to a careful levying of a hut tax and introduction of settlers in a wider and diverse aspect. Lansdowne's response to Eliot demonstrated his agreement with the general idea of introducing settlers into the country. Of course, Indian settlers might be encouraged, especially with a view toward increasing the prosperity of some of the up-country stations. The European settlers would also be welcome as a useful source of revenue: "Speaking generally, His Majesty's Government are most anxious to encourage settlers, and would welcome any well considered enterprises involving the expenditure of British capital and energy in the British

${ }^{51}$ Sorrenson, Origins, 62. 
Protectorate." 52 However, he warned Eliot that lines of future development were not yet clear, and that great care should be exercised to avoid the difficulties likely to be created by excessive grants of land to would-be settlers. And when military and police had become more efficient, and communication with Lake Victoria had been established with the completion of the railway, it would be easier, in Lansdowne's opinion, for the Government to study and profit from the economic wealth of the country, which Eliot had so stringently emphasized.53

Lansdowne's dispatch clearly mentioned the inclusion of Indians in Eliot's intent to bring settlers in the country. In addition to that, he made it clear to the commissioner that great care should be taken in the process of land allocation. Furthermore Lansdowne manifested concern about the importance of security and stability for trade to carry on safely.54 That meant that Eliot should be fair and careful in the execution of his plan.

Eliot understood Lansdowne's instructions but putting them in practice proved to be very controversial. The man on the spot was gearing towards a deliberately discriminatory immigration scheme. He focused on the mission of inviting settlers of European descent by promising them land that they could develop. Eliot engaged himself into diffusing the good news of the opening of a quasi-virgin country where settlers of his choice could prosper.

After the release of his first annual report that did not lack glowing accounts of an ideal territory of rich game consisting of beautiful highlands, with almost temperate

\footnotetext{
$5^{2}$ Lansdowne to Eliot, 27 August 1901, FO 2/433.

53 Ibid.

54 Ibid.
} 
climate reminiscent of the cool weather one feels in Britain, Eliot still found it not ineffective. The commissioner "prepared a pamphlet on settlers' prospects and had it published by the Emigrants' Information Office in London." 55 He reiterated the opportunities the protectorate offered to potential settlers. Eliot was indeed moving fast and was not shy on formulating policies to assist the settlers from the get-go by "reducing freights on the railway and reducing customs duties on seeds and agricultural implements. He created Agricultural and Veterinary departments to carry out experimental work on stock and crops, and provide services to settlers at subsidized rates." 56 In the midst of these first steps taken to change the economic direction of the protectorate from stagnation to miraculous rapid growth, while in London on leave, the commissioner was meticulously amending the land regulations to really attract and accommodate the potential European settlers who would take the initiative to resettle in the EAP. These first steps taken by the man on the spot and his earnest desire to count on a settlers' influx indicated his own aspirations to gain more power for the concretization of a white man's country that he firmly intended to create in the EAP. In fact, it was during Eliot's absence from the protectorate in September 1902, that the Crown Lands Ordinance was introduced. It made possible the sales and leases of land, but also the provision of licenses allowing temporary occupation of the then socalled Crown land. The ordinance clarified that the Crown had original title to land, and in case where the Africans vacated or deserted their land, they would de facto lose their property. That meant that, out of the blue, any unsupervised African land, in any case, was considered waste and reverted back to the Crown to be technically given to the soon

55 Sorrenson, Origins, 63.

${ }^{6}$ Ibid. 
coming settlers. The condition for the sale of land was clearly determined not to exceed 1,000 acres per lot without the approval of the Foreign Secretary. Also, more power was vested to the commissioner who, after considering that the purchaser of a land did not occupy and develop his parcel, could declare that land forfeited. As for the term of leasehold, the Ordinance provided that the settler-farmers would lease land for 99 years. That term replaced the 21 years land lease of the 1897 Ordinance. That resulted to each settler obtaining 160 acres of land free of charge as an inducement to develop it. The occupant could not transfer that land without the approval of the commissioner and was required to pay taxes to help build and maintain the infrastructure. Eliot turned the amended ordinance of 1902 into a discriminatory law allowing leases for European settlers and supposedly gave temporary occupation licenses for Africans and Indians. Unfortunately for the Africans and the Indians, it proved impossible to obtain a license to occupy land to farm or develop a trading business. 57

By the time that the Crown Lands Ordinance was introduced in September 1902 there were already some Europeans settled in the highlands. It was noted that there were only eight or ten settlers in the Kikuyu country, the most popular locality in the highlands. $5^{8}$ T. A. Wood, who was one of the rare early settlers, ran a hotel frequented mostly by other newcomers in the highlands. Wood's hotel became their political meeting ground. George. Bennett noted the following:

Early in January 1902 twenty-two Europeans met at Wood's to elect a committee to encourage white settlement. Their letter to Eliot seeking government support epitomizes the future themes of the settlers in Kenya: Land, labour, and opposition to the Indians. They want land to be granted in freehold, help through the establishment of model farms and a forestry department, and the passing of

57 Ibid.

$5^{8}$ Ibid., 65. 
mining laws; they asked that the natives should be made more 'amenable to European supervision' and describe Asiatic immigration as 'detrimental to European settlers in particular and to native inhabitant generally. 59

The commissioner took notice of their demands and promised to encourage European settlers to come to the EAP.

Looking closer at Eliot's willingness to collaborate with the early limited numbers of settlers to meet their demands, it stands manifest that any further influx of settlers would increase their number and result in generating new aspirations for more concessions. A stronger European settlers' presence in the protectorate would be of great significance when the urge for self government claims emerged. The early settlers' platform, generated at Wood's hotel in Nairobi, and focusing on land, labor and opposition to the Indians, resonated without reason. It was their first political manifesto. They much sounded like a group, such as a political party, that made its appeal directly to the commissioner. Churchill summarized it best in his African journey account. He stated that:

White settlement was both the baronial consolidation of conquest and the chief threats to the politics of control. If it could not have politically dependent but independently productive small farmers, the Colonial Office came round to the view that it must have big capitalist instead. Big capital would provide the state with a different but equally controllable answer to the nervous 'rhinoceros questions' of African rights in expanded production. It was 'no good trying to lay hold of Tropical Africa with naked fingers'. What was wanted was 'tireless engines, not weary men; cheap power, not cheap labour'. Capital was the axe with which to cut a path through political jungles as well as nature's. If only it could be given room to exploit African land, the state could 'regulate in full intricate detail' the relations between capitalists and the few skilled workers they would need. ${ }^{60}$

59 Bennett, "Settlers and Politics in Kenya," 266.

6o Churchill, My African Journey; 41 
White immigration sought to fetter Indian settlement and hoped to suppress any African initiative in organizing ways to be part of the system of production by reducing them to the status of squatters once their land has been alienated. The EAP political future was being shaped by Eliot's readiness to fully back up the European settlers. Following the gathering at Wood's hotel, another event worthy of consideration took place in November 1902, when Frederick Jackson, the acting commissioner, set rules for the protection of native rights and care for all the inhabitants, protection of forest and development of holdings and fencing. Nevertheless, many of the early settlers in Nairobi were not pleased with Jackson's new measure, even though it was along the lines of the 1902 ordinance. That sparked an agitation among the settlers who demanded Jackson to withdraw the rules. The leader was the Church of Scotland missionary, Dr. D. C. R. Scott, who considered the rules detrimental to the settlers' interests. ${ }^{61}$ Dr. Scott's reaction signaled a will of self-aggrandizement, ironically, in the name of a larger moral cause. The settlers were not to be held at the same level as an Indian or an African in the rise of a new developing socio-economic and political era of the protectorate. The settlers had the commissioner on their side, embracing the same philosophy of occupation, domination, production and accumulation of wealth without integration or the sharing of the market with the so-called other races or new subjects. ${ }^{62}$ In fact, when Eliot returned from London, he went to meet with the early settlers who were not pleased with Jackson's introduction of the new homestead system of settlement. After hearing their complaint, the commissioner, without officially meeting with Jackson on the issue, withdrew the rules. It was noted that, "Under Eliot's rules the

${ }^{61}$ Sorrenson, Origins, 63.

${ }^{62}$ Ibid. 
area of homestead was to be 160 acres but, if three-tenths of this was cultivated within three years, an additional area of 480 acres could be granted. The purchase price of Rs 2 (2s. 8d.) per acre could be paid at once or spread over sixteen years. A freehold title was to be granted on payment of the purchase price or after cultivation conditions had been fulfilled."63 The new rule was intended to benefit the settler planter. Also, the drafting of the rule opened the door for potential speculators. Any land speculator and ordinary profiteers could fulfill their payment and obtain their land title without meeting the development conditions. Eliot's new rule was porous in its drafting because it read "or after the cultivation conditions had been fulfilled," instead of "and after" fulfillment of the set requirements. 64

Meanwhile Eliot had so far taken sides in favoring the first settlers, who knew to whom and where to direct their demands. The cynical political agitation caused by the settlers in January and November 1902, combined with Eliot's readiness to listen to them, marked the beginning of the struggle for the control of power in the EAP. The first settlers also took notice of the way to proceed to defend their interests. They were aware of the fact that a considerable influx of settlers, well organized, could put pressure on any official sent to run the protectorate. Eliot triggered a land rush, opening the door for more eccentric settlers who accentuated the struggle for more concessions and political rights.

Moreover, Eliot's administration of the protectorate in the year 1903 was dominated by the extension of the homestead rules and the arrival of more settlers of all kinds who felt the need to organize themselves to defend their interests. In Eliot's

63 Ibid.

64 Ibid., 63-63. 
theory, unoccupied and sparsely occupied land could be reserved for settlers who would make good use of it. He sought the approval of the FO, suggesting the making of land within the railroad zone available for the good cause of European settlement. Offering free grant of 640 acres, east of Nairobi from Mazares to the Machakos road, and west from Naivasha to Fort Ternan, and affordable grazing land at minimal, nominal rent outside of the railway zone, would attract desirable investors. The FO naturally listened to Eliot because they knew nothing concrete about the African and the protectorate itself. On the other hand, the Treasury first remained skeptical and insisted on the importance of generating revenue to cover the cost of the railway construction. Land within the railway zone was a good asset for that cause. After a short deadlock, the Treasury allowed Eliot to proceed with his plan in March 1903 under the following measure: "The free grants were to be allowed in the districts Eliot had suggested but outside of the railway zone. Inside the zone he was to be allowed to sell one-third of each 640 acre block and lease the remaining two-thirds. The price was to be substantial. Lansdowne instructed Eliot not to sell more than one-quarter of each block of railway land, but allowed him to fix the prices."65 Once again, Eliot succeeded in convincing officials in London to accept his initiatives. His work would benefit potential newcomers entering the protectorate. In 1903117 whites applied for land grant, and in a following year "599 immigrants made three hundred applications." 66 European colonists' response to Eliot's settlement invitation

Before the first considerable wave of settlers entered the protectorate to claim and occupy land in April 1903, talks about experimenting in settlement with other races

65 Ibid.,64.

${ }^{66}$ Shadle, The Souls of White Folk, 14. 
had long been discarded: "The state's early essays in immigration had an air of desperation about them: Punjabi peasants, Finnish homesteaders, and persecuted Jews from eastern and central Europe; all had their passing attraction.” ${ }^{67}$ It was under Eliot's administration when the protectorate saw the arrival of some eccentric settlers who later became charismatic political leaders defending their interests. The settlers who responded to Eliot's invitation were from different social backgrounds, but nevertheless, their interests in obtaining land and political aspirations for the acquisition of power would eventually emerge and converge. They felt the need to form political entities to secure leverage at a crucial time in order to defend their interests. That common denominator drove the settlers' community into the political arena of the protectorate. As stated earlier, among the group of settlers who set foot in the protectorate, there were aristocrats, business adventurers, small and big farmers, Anglo-Boer war veterans and land speculators.

The most prominent aristocrat and business adventurer was the third Lord Delamere who was already familiar with the region.

${ }^{67}$ Bruce Berman, Control and Crisis in Colonial Kenya (Athens: Ohio University Press, 1990), 55. 


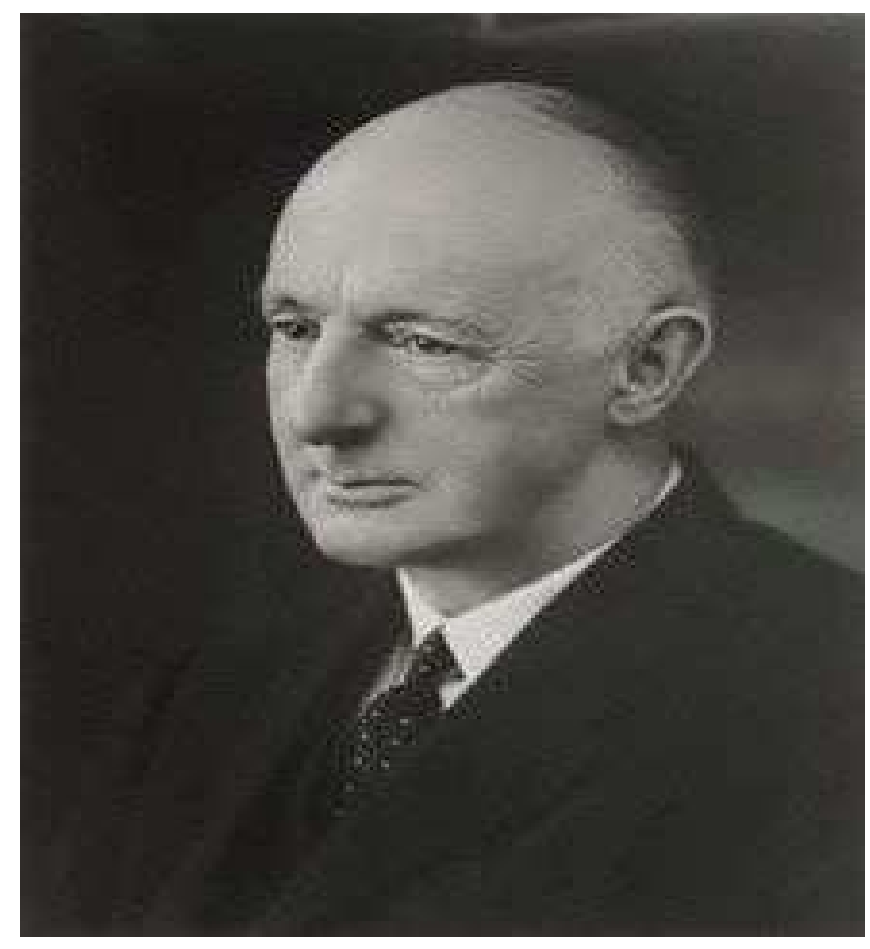

Image 2: Lord Delamere. Source: Huxley, White Man's Country, see preface.
Lord Delamere was born Hugh Cholmondeley in 1870 at Vale Royal in Cheshire, England, and died in 1931. He was a pioneer European settler, farmer, and politician. Educated at Eton, at the age of 17, he succeeded his father as the third Baron Delamere of Vale Royal. In 1897, Delamere first entered Kenya on a big-game hunting expedition. In 1903, he returned to Kenya, where he remained for the rest of his life. Historians have noted that, "Shortly after Delamere's arrival, Sir Charles Eliot granted him 40,500 hectares (100,035 acres) of land on a 99-year lease in the White Highlands; subsequent land grants/purchases increased the size of his estate." 68

Delamere's peculiarity, spirit of adventure and ambitions soon caught

the attention of the first government officials like Ainsworth and Jackson. Note the following description in the account from Ross, Kenya from Within:

One afternoon in 1898 the District Officer in charge of the inland station of Machakos was informed by his wife that there had just arrived upon the verandah a singularly dishevelled traveler who announced himself as Lord Delamere. After tea with this Mr. and Mrs. Ainsworth, Lord Delamere excused himself from returning for dinner on the grounds of the disrepair and scantiness of his outfit. He had not known when he first called that 'there were any ladies in the station.' He had come South through Jubaland and Tanaland by camel and porter caravans, and was now proceeding to meet the railway construction parties as they approach the site of Nairobi, and so go on to Mombasa. His camp exhibited all the evidences of a dashing and adventurous journey through wild country, and next morning he moved away Southward with his companion, Dr. Atkinson. ${ }^{69}$

68 Robert M. Maxon and Thomas P. Ofcansky, Historical Dictionary of Kenya, Third Edition (Lanham MD: Rowman \& Littlefield, 2014), 73.

${ }^{69}$ William McGregor Ross, Kenya From Within (London: Frank Cass and Company Limited, 1968), 59. 
Delamere sure left an impression on Ainsworth, the main official who, to some degree, fought for the consideration of African rights to land and their incorporation in the economic system of the protectorate.

In 1903, a different Delamere again crossed the path of Ainsworth, but under different circumstances. This complex figure was also an active political advocate for a white man's country. Even before settling permanently, he gained the sympathy of Eliot. When he applied for a government post under the motive of alleviating settlers struggles under official hostility, the commissioner created a position to fit him in his scheme of carving out a white man's country: Eliot offered him one "specially charged with the affairs which concern the white settlers," and recommended his appointment as a sub-collector, coupled with that of Land Officer as an experiment. He apparently accepted Delamere's views, for he explained to the Foreign Office that Ainsworth, the then Land Officer, had too much to do and was "quarrelsome with the settlers." Before the appointment could be concluded Delamere was laid up as result of a riding accident. 70

Delamere and Eliot strengthened their ties prioritizing white settlement to the point that Jackson, Eliot's Deputy Commissioner, alerted the FO. Bennett well illustrated it with Jackson's dispatch to the FO. Jackson claimed that: "The protectorate was becoming a country of 'nigger-' and game-shooters." He described one leading settler as "a well know filibuster," saying that he and Delamere were "as thick as thieves." Moreover, he believed that Eliot had come under Delamere's influence and was kow-

\footnotetext{
70 Bennett, "Settlers and Politics in Kenya," 269.
} 
towing to the settlers, the majority of whom Jackson regarded as "a lot of scalliwags." 71 Delamere went on to whole-heartedly believe that the opening of the protectorate was a period of enlightenment beneficial for the Africans that he viewed as inferior to the white civilized races and whom he thought, for a long time in history, remained in darkness. He was a man of his time, a deluded social Darwinist. By trying to justify the antiquated theory, he was undermining the Africans and Indians' rights. Social Darwinism embedded in many Europeans' minds. These were so-called "men of their time.” Delamere's ideology did not stop him from dispossessing Africans from their land. He permanently settled down in the protectorate and applied for land in 1903. Upon obtaining a good portion of land, he vehemently sought to succeed in agricultural and pastoral experimentations.

Nevertheless, after permanently settling down in the region, Delamere became deeply involved in politics. His volatility and determination to transform the protectorate into a European settlers' colony propelled him to become the political leader of the commissioners' guests. His political career was dominated by the defense and promulgation of white interests and the quest for political control of the protectorate. As depicted by Maxon and Ofcansky, he hit the political ground of the EAP running.

Within a year of arriving in Kenya, Delamere established himself in the political arena by becoming president of the Colonists' Association. In 1907, he was one of the first two unofficial members appointed in the Legislative Council (LEGCO). After his election to LEGCO for the Rift Valley in January 1920, Delamere became the acknowledged leader of the European settler community. Apart from advocating the policy that excluded African and Asian landowners from the White Highlands, reserved for the exclusive ownership of European settlers, he

${ }^{71}$ Ibid., 268. 
also led the campaign for a popularly elected unofficial majority in LEGCO (never achieved in his lifetime). 72

Among the early settlers, the aristocrat adventurer and settler Delamere had no parallel in his political influence, character, charisma and extremities, even compared to other aristocrats who were also present in the protectorate. E. Huxley highlighted the very nature of many of the settlers who were entering the protectorate with the following description taking note that, "European settlement in Kenya has always had a strong aristocratic flavour: one of Nairobi's hotels became known as 'the House of Lords.' But then, and for some years to come, Nairobi's conditions were those of the frontier. Delamere himself appeared as the typical frontiersman, with hair flowing down to his shoulders, wearing disreputable clothes, and capable in irritation of locking the manager of that same hotel in the meat safe with several dead sheep.73 Delamere's use of threat and violence to make an impact in the region would became a tactic that other vocal and volatile settlers would also adopt in their intent of dominating the region socially and politically.

Another Briton, who arrived in the EAP in May 1904 and immediately immersed himself in settlers' politics there, was Captain E. S. Grogan. In a character and adventurous nature somewhat akin to that of Lord Delamere, Grogan came to be known as the "boldest and baddest of a bold, bad gang" of outlanders proliferating throughout the protectorate and making their marks in the region. Grogan lived up to his reputation by violating the law in the protectorate without any severe consequences. Grogan had no regard for the rights of the Africans he thought that he owned. In order to set an example, he dispensed cruel punishment to any of his workers whom he

${ }_{72}$ Maxon \& Ofcansky, Historical Dictionary of Kenya, 73.

73 White Man's Country (London, 1935), vol. 1, passim, as quoted in Bennett, "Settlers and Politics in Kenya," 278. 
thought misbehaved. It was Grogan who opened the very chapter of the question of impunity in the protectorate. Would the newcomers face the law in case of any violation of African rights? Would justice be served in any case of misconduct on the part of the settlers? The answers to these questions depended on how London supervised the protectorate. With the presence of the European settlers in the protectorate as a fait accompli, the question of the maintenance of law and order became a must for the authorities in London. Settlers of the likes of Delamere and Grogan were politically active and conflictive.

Grogan was not an aristocrat like Delamere. However, he was a risk taker who gained his fame for being the first recorded British adventurer who successfully made the journey from the Cape to Cairo; and like Delamere, Grogan was familiar with the interior of the protectorate.

Grogan, Ewart Scott (1873-1967). Explorer, farmer, entrepreneur, and staunch advocate of European settler rights. Born in London and educated at Jesus College, Cambridge. In late 1903, he arrived in Kenya and quickly acquired a considerable amount of land, including the Chiromo area of Nairobi, the Kilindini region of Mombasa Island, and a timber concession in the Rift Valley. Additionally, he was a coffee and sisal farmer. He also used his skills as a writer and orator to gain influence among Kenya's European settler community as an advocate of white supremacy and a critic of Colonial Office rule. 74

74 Maxon \& Ofcansky, Historical Dictionary of Kenya, 127. 
The news of Grogan' accomplishment echoed in London and the rest of the

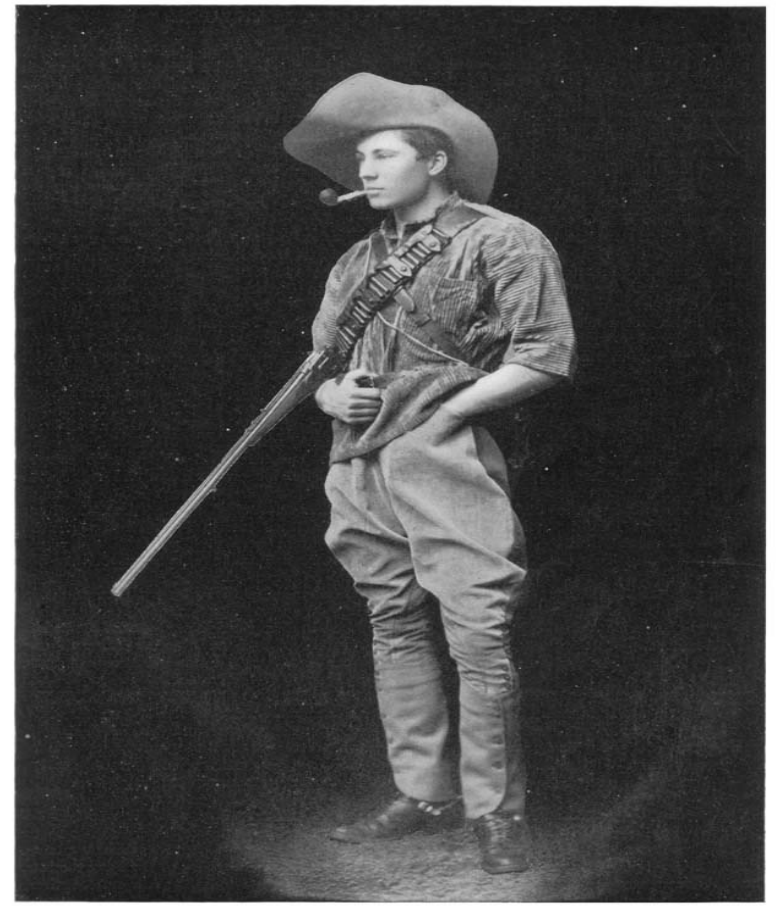

Image 3: E. S. Grogan. Source: Pace, Lost Lion, 126. colonies. When he came to settle in the EAP in May of 1904, he was not alone, and considering that Eliot was desperately in search of large or small scale investors for his scheme of European settlement to concretely materialize, the commissioner and Grogan's visions quickly started to converge. The two men entertained the belief that European settlers with some initial investment, could indeed, turn the protectorate into another white settler colony, parallel in standard to the self-governing system extant in South Africa. The commissioner was quickly enchanted by Grogan's entrepreneurial plan of engaging in a lumbering business in Lembus. Lembus was a region of immense ecological importance, characterized by its rich forest land lying across the water stream separating the river systems of the Rift Valley and the western part of the protectorate. Although, the Nandi occupying the region remained to be dealt with militarily, Eliot allowed Grogan to inspect the forest, which should have been done by a competent land surveyor, not by an adventurer venture capitalist with an appetite for land acquisition. He finally obtained the area of land he specifically wanted and was going to exploit it with African labor.

Grogan was the prototype of the settler that the commissioner, as well as the FO, wanted to welcome for the development of the protectorate, investors with capital and clear ideas. Grogan eventually settled and got involved in the timber industry in 
partnership with other investors from South Africa. Lingham \& Neame, a South African timber company based in Johannesburg hired Grogan in May 1904 as their agent. They entered into an agreement with two of their compatriots, land speculators Charles Grant and George Fotheringhame, to exploit and export timber. The commissioner opened the door for Grogan and accommodated him. Like Delamere, Grogan permanently settled in the protectorate.

Such was Grogan's growing influence on the commissioner to the point that in March of 1904, he requested land to be reserved for his brother in law, E. J. Watt, who might visit and possibly settle permanently in the newly opened protectorate. In this case the commissioner could bypass the FO.75 Although newcomers could easily apply for land of their choice, obtain their prize and settle down; Grogan's request of 500,000 to be reserved for Watt and other potential settlers coming from New Zealand was treated with caution. Considering the commissioner's commitment to populate the country with European settlers, his response was more likely to be interpreted as a measure of caution vis a vis the officials in London about his flagrant violation of African land rights. It was a matter of time before the FO found out Eliot's illegitimate practices of facilitating land to his preferred settlers. The commissioner attracted Delamere and Grogan, two of the most influential and conflictive settlers who contributed to the reason why the EAP became what some considered the most troublesome dependency of the British Empire. Eliot had his own formula of land regulation that benefited the European settlers in general.

\footnotetext{
75 Grogan to Eliot, 2 June 1904, FO 2/837.
} 


\section{Widening the gate for more settlers}

The changes made on the 1902 land regulations opened an avenue for a direct settlement for those who would make the journey to the protectorate. It was based on that power to manage land that in June 1903, Eliot promised to set apart land for Robert Chamberlain and A. S. Flemmer, who had helped in the scheme of attracting some 100 farmers from South Africa. Chamberlain and Flemmer wanted 100,000 acres of real estate as compensation for their effort in bringing in settlers. In addition to this in August 1903, the commissioner took another step ahead to reinforce his campaign of inducing European settlers from the south of the continent to come make a fresh living in East Africa. He sent his Collector of Customs, A. Marsden, to do the task of spreading the good news from the newly opened EAP. Marsden did not fall short in describing the protectorate as a heavenly region, which was in reality a bubble of extrapolations. ${ }^{76}$

Eliot was ready to sell the most exotic and healthiest land of the protectorate for an unreasonably cheap price, which of course was a contradiction to the very logic of higher land prices for the most valuable land. Eliot's land policy attracted more speculators and also turned some regular farmers into speculators. The price of land bounced up. Ross underlined that: "One English farmer received a freehold estate of some 2,000 acres close to Nairobi, which he worked as a lucrative dairy farm for ten or a dozen years, and then sold for £20,000 as a building estate.”77 Eliot’s policy and promises of land excited other investors who thought of the protectorate as a potential region sitting on mineral resources that could be very lucrative if well exploited. Some

${ }^{76}$ Natal Witness, 24 October 1903.

77 Ross, Kenya from Within, 63 
Englishmen gentlemanly capitalists thought of the EAP as maybe another South Africa, a region rich in gold and other minerals. They decided to claim big portions of land.

Some respectable investors from London and South Africa formed a coalition under the umbrella of the East Africa Syndicate in May 1902 and demanded a large portion of land to be prospected for minerals. After a year-long expedition directed by Major Burnham, the search for minerals proved fruitless. There were no considerable deposits appealing enough for any enterprise, because it may have involved risky investments. The project was abandoned but the desire of acquiring land remained intact. That burning aspiration led the Syndicate to push for land request. Burnham entered into negotiations with Eliot about acquiring a vast agricultural land around Nairobi. Having again convinced the FO of the need of attracting investors, Eliot facilitated Burnham's huge land concession with a cheap price. 78 The commissioner was catering to some would be speculators and it was just a matter of time before the very officials that Eliot once viewed as mere English gentlemen lacking colonial incentive, reacted to his extravagant land alienation by alerting London about the reigning situation in the EAP.

The number of speculators disguised as settlers could have been higher, if it were not for the constant concern of Lansdowne warning Eliot against large sales of land to grazers or land speculators. As Sorrenson observed, in January 1904 G. V. Stewart, "who had established two settlements of Ulstermen in New Zealand in the 1870's and 1880's, proposed to settle 200 families from 'home'-presumably Ulster-in the Protectorate in return for an undisclosed fee. Eliot decided that it was unnecessary to

\footnotetext{
${ }^{78}$ See Sorrenson, Origins, 71.
} 
pay Stewart to obtain settlers."79 Eliot's decision on Stewart's proposal seemed to have been motivated by Lansdowne's pressure for caution. But in reality there was already a saturation of land demand in the protectorate. The local administration had to deal with the overwhelming land applications in a region that had not been properly surveyed. Eliot triggered a land rush that was out of proportion.

It was not until May 1903 that it was deemed necessary to have a Land Officer for the work of the Land and Survey Department to be more effective, if it had ever been in any case. R. Barton Wright, a railway surveyor, was appointed to the task while the influx of settlers from South Africa was at its peak. To make the situation worse, more settlers, who knew their veldt pretty well and also understood the meaning of the South African political system, were coming to the EAP. "Every steamer brought its quota of intending settlers. The growing crowd soon overran the limits of Nairobi's accommodation and a canvas village, locally called Tentfontein, sprang up near the Land Office in the valley of the river Nairobi." 80 That was an indicator of the birth of a new socio-economic dynamic that will be cemented by the settlers' common interests in the furtherance of their political aspirations. The settlers growing numbers and their political history experienced in South Africa, turned out to be important factors when the time to organize themselves around political entities arrived. "One friend of the South Africans described them as 'an exceptional stamp of colonist, accustomed to taking and giving hard knocks in life: even better still, [they] had mostly farmed in Southern Africa and fully understood the handling of native African peoples." 81

\footnotetext{
79 Ibid., 66-67.

80 Ross, Kenya from Within, 64.

81 W.R. Foran, A Cuckoo in Kenya (1936), 96 as quoted in Sorrenson, Origins, 68.
} 
The migration from South Africa was a minor repercussion of the Anglo-Boer War and post-war depression caused by the withdrawal of troops, a shortage of labor in the mines and the slow recovery of the war-torn economies. ${ }^{82}$ To many settlers from South Africa, the Anglo-Boer war was detrimental to their interests. The war brought nothing new but the control of the mining magnates. Some discontented settlers of British descent represented the first wave that came to start a new living in the EAP. The immediate post-war era and its consequences, coupled with the effort of inducing potential newcomers by promising land on easy terms, attracted antagonistic settlers from South Africa to East Africa. Sorrenson argued that: "The South Africans formed the most volatile, vocal and influential element in the pre-war settler population of the protectorate. They were at first almost entirely of British descent. Later, when the Boer 'Irreconcilables' and another party of Boers under the leadership of J.A.J Van Rensburgh arrived, it appeared likely that the old South African antagonisms between Briton and Boers would be reproduced in the East Africa Protectorate. But the Boers took little part in Nairobi politics and most of them, characteristically, trekked to and settled the isolated Uasin Gishu plateau." ${ }_{3}$

Although, the highest number of migrants that settled in the protectorate came from South Africa, it is worthwhile to take into account another group of war veterans of the Anglo-Boer war that moved to the EAP. They were Australians, New Zealanders and Canadians who could cohabitate with the South Africans of British descent and share the same political ideology and aspirations. The desire to establish an exclusively white man's country, by systematically excluding other races, undermined the basic rights of

${ }^{82}$ L.M. Thompson, The Unification of South Africa, (1960), 52-54 as quoted in Sorrenson, 65.

83 Sorrenson, Origins, 66. 
the people whom the protectorate by righteousness, and responsibility was supposed to protect for the sake of revenue and good moral cause, to per-se, justify the need of expanding the Empire.

The people who were not part of Eliot's plan to develop the region were those who remained to be considered and qualified in the very darwinian context as the unwanted Jews, the undesired Boers, the feared Indian traders and the despised Africans. Such was the social nature of the country that the man on the spot, the welleducated diplomat Sir Charles Eliot, was pioneering. A country, as Hobley observed in 1904, where the settlers stood "indifferent as to the line that the Administration took with regard to native affairs as in a very few years it was probable that the country would fall under the Colonial Office and that they would then insist on local autonomy and the formation of a legislative assembly, this body would then dispose of native rights in a very summary fashion and put the Masai etc. where they could not interfere with anyone." 84 To reach that stage in the EAP, the settlers started by the formation of political organizations to channel their political agenda. The start of European political organizations

Commissioner Eliot succeeded in introducing settlers in the protectorate and the consequences of the social changes that came along with their presence led to a political conflict of interests. A power struggle in the EAP started to be determined by the settlers' relationship to the state. As a group, the settlers' capacity to define, defend and develop their interests would ultimately determine the meaning and use of power in the political context of a newly established social order. The settlers whom Churchill

\footnotetext{
84 Quoted in Ibid., 68.
} 
referred to as, "political animals", during his 1907 visit to the protectorate, understood the process that could lead to the acquisition of power due to the fact that many were unconditionally familiar with the South African political system that left less to desire from the perspective, if even perceived, of the Africans.

The settlers were able to define their interests by articulating and establishing them through the creation of political parties. They knew how vital it was to protect themselves and their interests against any potential challenge because in Eliot's white men's country, divided and defined by the concept of race and class, any conflict of interests in that context consequently assumed a race and class character. The safeguard and development of the settlers' interests depended on how they organized themselves to first promote and expand their political influence in the protectorate to further reach the full stage of acquiring and controlling power. The settlers influence as a group was felt early in 1902 when they gathered at Wood's hotel to elect a committee to encourage white settlement and oppose an Indian presence in the region. A group of settlers, of a number no larger than 22 members, was starting to be politically active. ${ }^{85}$ In September that same year, the settlers gained political terrain and consideration when they pushed for changes on the homestead rules put in force by Jackson under the terms of the 1902 Crown Lands Ordinance. The rules were reversed due to settlers' complaints, influence and Eliot's support for their claims.

The small European community gained influence, which directly depended on their relations with the commissioner who acted as if he was very keen on listening and advising the newcomers. That revealed a striking dissimilarity between his true nature

85 See Bennett, "Settlers and politics in Kenya," 266. 
and the way he dealt with the settlers. Eliot did not intermingle with the settlers very often. He invited them to the EAP as a result of his vision of establishing a prosperous white men's country. He did not consult his subordinates or set any meeting before engaging in negotiation with the newcomers asking for their share of real estate. His subordinates obviously noticed the commissioner's daring and unfair policy making. Some officials under Eliot took notice of the evolving situation with settlers growing influence in the protectorate. Jackson and Bagge's (then a sub-commissioner) opposition to the man on the spot dragged on and eventually reached its climax when they finally alerted the FO about the developing situation in the EAP where the political climate was dominated by the political shaping of what was intended to become a self governing country with successful and influential Europeans settlers. ${ }^{86}$

Settlers like Right Honnorable Lord Delamere, Lord Cardross, Captain Grogan, T. A. Wood, S. C. Fichat and few others present in the EAP during the early stage of Eliot's administration gained considerable influence. In the new social context of the EAP, it is important to draw the line between the control of power and influence. For whereas the commissioner appointed by the FO to handle British interests in a supposedly dignified manner with regard to the subjects' rights, had the capacity to formulate and execute policies which meant the exercising of power, political influence, which meant the ability to affect important political decisions making, rested entirely on a few settlers hands. In the EAP, a small group of settlers had tremendous influence with Eliot and that passed in their circles' as having the control of power itself, but that was a huge political misconception from their part because the FO was still in control of

${ }^{86}$ Mungeam, British Rule, 108. 
the protectorate. A laissez-faire policy violating African rights in the protectorate was not going to sit well in the England where the public opinion can shape debate in parliament and question the very meaning of the protectorate vis a vis African rights in Africa itself.

The settlers' socio-political capacity was rooted in their main collective group ability. The settlers' leaders had the organizational and institutional ability to match their agenda with the commissioner's vision. They understood the rationale for party politics, and that brought them to form key political structures which were the right locomotive that could carry them to the station of self-government sanctioned by the full control of power. As Bennett described it: "In 1902 the committee to encourage European settlement had led to the formation of a Colonists' Association, which Eliot had welcomed as a source of valuable advice. Delamere, on his arrival in January 1903, formed the Planters' and Farmers' Association. Concerned initially with the marketing of potatoes in South Africa, it soon turned to a more vital life in politics and superseded the older body." ${ }^{87}$ An only white man's political party was born to stay active and influential, not hesitant to raise hell and intimidate authorities. They posed proud and looked confident in the following picture with Delamere in the middle of everything and everywhere when it came to the political direction they should take.

87 Bennett, "Settlers and Politics" 273. 


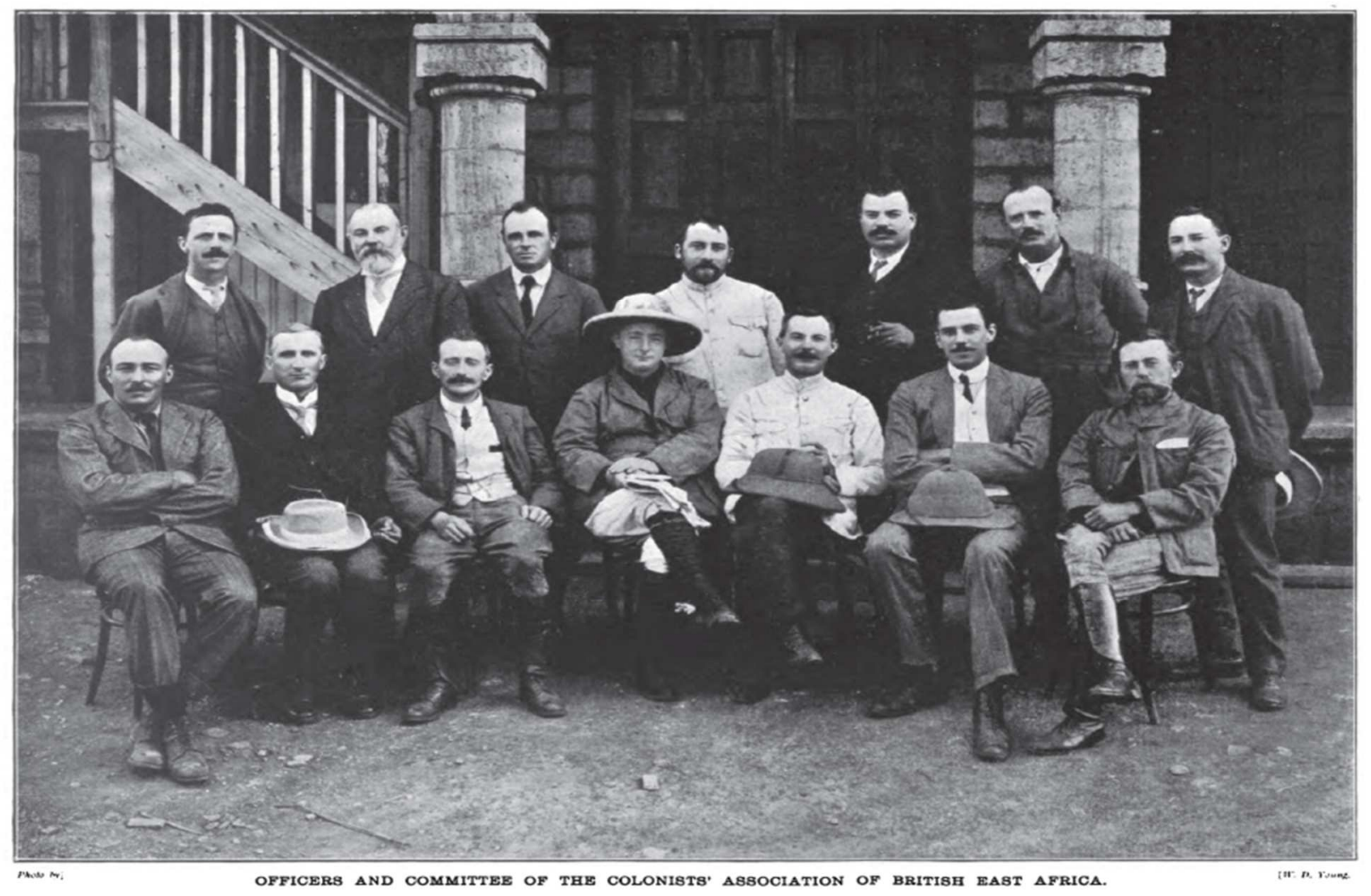

Image 4: Officers and Committee of the Colonists' Association of British East Africa, 1903. Source: Gale, East Africa (British), 166.

Under Delamere, the association went active pressing for the best land to be reserved for white settlement. Delamere, in particular, categorically opposed the presence, cohabitation or participation for economic development of any other race in the new region solely opened for white settlement according to his logic shared by the commissioner in person. So influential was Delamere that he made it clear to the FO that the European settlers would go as far as necessary to oppose any interference that could threaten their hegemony or interests. ${ }^{88}$ Eliot advised them by pointing them the right direction to follow after the creation of settler political party. Nevertheless, it was

88 Delamere to Lansdowne, telegram, 2 Sept. 1903, F.O. 2/785 
not until 1904 that Eliot gave full support to the settlers for the initiative of a LegCo. He suggested it in these terms: "One consisting only of officials, but in a final communication to the Planters' and Farmers' Association, he said that they must strive for 'some local Government': they could not expect representative government, but they could have a council with unofficial members. He believed that such a council, with some financial power, could have taken the initiative in providing roads and services to intending settlers and thus might have prevented many of the difficulties of the past eight or ten months." 89

It was clear in his dispatch to the FO that political power meant the domination of the very institutions which were essential to carry on governance and insure social control. Eliot's suggestion was a total turn away from his passive approach first taken in 1902 when an earlier petition for Advisory Council with unofficial members was made by a group of Europeans and Asians in Mombasa. He then dismissed the Europeans, just temporarily, and as regard to the Asians, it was a systematical and direct dismissal for any form of political hope. $9^{\circ}$

For their part, the settlers engaged in a political party to achieve their group and personal interests. Within the framework of their party's focus, the European settlers believed that they could ultimately control or effectively participate in state power. Their party was a very important link to power to defend and promote their interests, to have the means of becoming their own group representative via elected or appointed members. The party also gave them an opportunity to hopefully participate in the determination of the East Africa white protectorate's public policy and to ultimately

89 Bennett, "Settlers and Politics" 272.

90 Ibid., 273. 
reach the level of being able to affect, for their own advantage, the power of distributing governmental funds, jobs or political positions. The sharing of party patronage was crucial for the settlers' interests, and Eliot did show signs leaning to that direction when he offered a position of sub-collector coupled with that of Land Officer to Delamere who opted instead to apply for land. Delamere was best suited with being the president of the CA while possessing a big estate with quasi-free labor from the Africans' who would remain as land-losers, forced to pay tax. European settlers' political aspirations echoed all the way to London and the FO had to intervene because of the obvious violations of Eliot regarding the issues of land promises, land alienations and segregationist policy that tended to exclude the African and Indians in the protectorate. In 1904 the FO had enough of Eliot's stubbornness and policy making. The well-regarded commissioner, who only catered to European settlers, had to go. Eliot himself knew that his fate was sealed. He precipitately anticipated his departure by quickly tending his resignation to Lansdowne.

The end of Eliot's administration and its consequences

Eliot's resignation was the result of a clear mismanagement of land just to please some of his favorite newcomers. From the beginning of his mandate, Eliot's administration was mainly dominated by a policy of land alienation favoring the European settlers he invited to develop the protectorate. The process of land distribution on easy terms was disorderly conducted. Land was not properly surveyed and a laissez-faire of first come, first served policy followed. Officials like Jackson, Bagge, Ainsworth and the land officer Barton Wright were overwhelmed by the situation. No measure of caution was taken by Eliot not to infringe with African rights to land in the EAP. The Kikuyu and the Maasai were among the most affected. The 
situation reached a climax when "in pushing ahead with the settlement of the Kiambu district, Eliot ignored the warnings of his local officials who reminded him of the danger of dispossessing the Kikuyu. Because of the chaotic situation, the officials under Eliot could only manage to achieve "a haphazard division of the land between the settlers and the Kikuyu, with payment of compensation for dispossessed Kikuyu. Eliot attempted to use the policy in the Rift Valley, this time in the face of protests by Jackson and Bagge who appealed to the Foreign Office, not merely over the Maasai rights, but also over the question of granting concessions in the Rift Valley."91

The commissioner went too far in his intention of creating a white men's country ipso-facto without taking into account the Africans or Indians rights, at least as subjects by right in the same protected crown land to say the least. Under Eliot the EAP highlands were reserved for the arriving European settlers. Eliot felt justified in sanctioning large freehold grants of land to prospective speculators disguised as desirable investors without the full consent of the FO and the Treasury. The case of the East Africa Syndicate that went to engage in negotiations with Eliot to cut what became their greatest land deal was a result of an effective scheme of persuasion used by one of their managers in London. In the FO, Hill worked on behalf of the syndicate to persuade the Treasury to allow them a large concession because of their possible large investment. ${ }^{2}$ The protectorate was in need of money and big investors seemed to be the best answer for Eliot and officials like Hill at the FO, who was lobbying for the syndicate's interests.

${ }^{91}$ Sorrenson, Origins, 70.

92 Ibid., 73. 
Sir Clement Hill fell under the influence of the syndicate's London manager, Major C. H. Villiers, who sought Hill's backing to bring the Treasury to come on board and allow their freehold deal to concretize. Hill's collaboration with Villiers was a clear indicator in his belief to the importance of attracting investors who could benefit with a grant of large concessions suitable for the development of their business adventure. Hill's approach about revitalizing the economy of the protectorate was parallel to Eliot's vision, which created the situation of having to fill up the protectorate with desirable investors. Eliot did his best to widen the door for whoever he also promised land. The commissioner was in tune with the big men who claimed land that was promised to them. In the following case, Eliot circumnavigated the vigilance of the FO and Treasury to facilitate large portions of land to Chamberlain and Flemmer for their labor of bringing around 100 settlers in the region in 1903.

In that case, it later resulted that the two South Africans that were working for Eliot to attract settlers were really interested in the business of land speculation. That was the reason why they wanted a large portion of land to make a maximum profit by selling back their real estate when the land prices soared up. Jackson complained again to the FO about Eliot's practices. Lansdowne demanded explanation on that issue, thinking that the land deal for the case of Chamberlain and Flemmer was not yet concretized. Surprisingly, "Eliot went on to admit, for the first time that he had instructed the Land Office to draw up leases with Chamberlain and Flemmer. They had signed the leases and, accordingly, the Law Officer, J.W. Barth, had established a prima facie claim.”93

93 Ibid., 76. 
That was it, when Eliot could not legally back track from Chamberlain and Flemmer's land deal; he decided to face the FO with dispatches trying to justify his decisions. His exit option was a precipitate resignation because he could not make his case hold ground before Lansdowne who in return may have to appear before parliament on issues related to the handling of the EAP territory. Eliot completely disregarded the question of African rights to land; to him; no valuable land was an exception for alienation. With that firm belief, even the Rift Valley felt in the same sphere of territory to be purely and simply alienated. Dispossessing the pastoralist Maasai from their grazing land and even eradicating them from the face of the earth in the process was, according to Eliot, a great service to humanity. That was one of his argument points when in April 1904; he invaded the FO with a series of dispatches explaining the why of his resignation. 94

The resignation of this renowned intellectual and diplomat was not amiable at all. Eliot went on to play the victim's card that seemingly meant giving the impression of being blamed by the FO for intending to accommodate settlers of his choice, even though during his tenure, the commissioner was far from being easy to approach by his new guests. The commissioner held grudges against Jackson, Bagge and mostly Hill, whom he directly attacked in his evaluation of the whole situation. Eliot was not shy to express his feelings and what he stood for. His dispatches clearly reflected his firm belief in the necessity of forging a white men's country at the expense of the Maasai and

94 As described in Sorrenson, Origins, 75. 
the Kikuyu in general. To the FO, Eliot sent his poignant letters of complaints, disgust and intent of self-justification. 95

The commissioner was a career diplomat with a monumental pride and having been by-passed by Jackson and Bagge, who were his subordinates, brought him to tender his resignation to Lansdowne. Eliot took it as an insult, a despicable and disrespectful maneuver against his good intentions and initiatives towards opening the protectorate for European settlement. Concerned with the probability that the delicate question of land grants and native rights could be raised in parliament, Lansdowne explained to Eliot the reason why Jackson and Bagge were consulted. At first, Lansdowne did not accept Eliot's resignation based on the criteria that the refusal of the Chamberlain and Flemmer land application was a measure of prudence. In the EAP, arbitrary land alienation was feared to lead to outrageous violations of African rights to their most valuable locomotive of subsistence. For instance the pastoralist Masaai had long been using the Rift Valley to raise their cattle by seasonally grazing the highlands, conducting it up and down the interior of the region. Considering that reality of Maasai tradition, a careful management of their territory was deemed necessary. Lansdowne argued that caution and wisdom was the best approach in the conduct of land policy in the EAP. Lansdowne had to cover his back, in case that the subject of land grants and native rights in the protectorate was to be raised in the parliament. 96

The foreign secretary's approach did not please the commissioner. There was a paradox in the way that Eliot reacted after hearing from Lansdowne's concern about the risk of possible swift alienation of Maasai land. The man who felt by-passed by his

95 Ibid.

${ }^{96}$ Ibid. 
subordinates did not in return inform the FO about the signed leasehold agreement in favor of Messrs Chamberlain and Flemmer. Lansdowne instructed Eliot not to exceed 1,000 acres of freehold land. Eliot did not pay attention at all. He had his own way of conducting business with the settlers. At the beginning of the 1904, he claimed that; "Although Messrs. Chamberlain and Flemmer are nothing to me, I am quite determined to resign if I cannot do them what I consider justice" 97 Doing justice to Chamberlain and Flemmer meant paying them with African land and Lansdowne did not want to hear that.

Behind closed doors, the two gentlemen who advertised the EAP natural wonders in South Africa got their recompense. As Sorrenson observed, "Eliot admitted that their colonization scheme had been abandoned, but, as Lansdowne had instructed him to encourage 'small capitalists', he had offered them 'moderate' grants."98 Again Eliot insisted on trying to justify his actions. One thing was encouraging small capitalists, and why not big gentlemanly capitalists investors, and another was where to let them settle and how they were going to purchase a lot of cheap land. Knowing that he had already exceeded his powers, Eliot blamed Jackson, Bagge and the FO for belittling and overruling him. His dispatches were filled with rage. One was a general defense of his actions and policy. Still hurt by the Foreign Office consultation of Jackson and Bagge, or as he put it 'overruled by my own officers', Eliot believed that "there was 'not a Head of a Mission in the Diplomatic Service who would not send in his resignation when so treated."'99

\footnotetext{
97 As quoted in Ibid., 75

98 Ibid., 75

99 Ibid.
} 
There was no doubt about the fact that Eliot was an intelligent diplomat, not short of intellectual vision, but he seemed not to realize that he did by-pass the head of the FO with Chamberlain and Flemmer's lease agreement. There was no reason for the proud Eliot to be offended on that matter to the point of having to resign. The commissioner even went so far in his reflections and confession about the futility of the Maasai rights to land and their existence in general. Eliot viewed the Maasai as a nuisance and believed in their extinction. The man on the spot was a man of his time who fully embraced social darwinism, after encountering so many non-British people, usually described as uncivilized subjects, he manifested a particular disdain vis-a-vis the Maasai. In another dispatch, marked private but not top secret, because Hill later used it against the man on the spot, Eliot made a self-destructing remark. The content was shocking. On April 1904, Eliot stated that:

No doubt on platforms and in reports we declare we have no intention of depriving natives of their lands, but this has never prevented us from taking whatever land we want. . . .Your Lordship has opened this protectorate to white. . . . colonization, and I think it is well that, in confidential correspondence at least, we should face the undoubted issue --- viz., that white mates black in very few moves. ... There can be no doubt that the Masai and many other tribes must go under. It is a prospect which I view with equanimity and a clear conscience .... I have no desire to protect Masaidom. It is a beastly, bloody system, founded on raiding and immortality, disastrous to both the Masai and their neighbors. The sooner it disappears and it is unknown, except in books of anthropology, the better. ${ }^{100}$

That was a critical analysis and the commissioner missed the point of the very essence of social darwinism. If cruel, beastly and bloody as Eliot stated, the Maasai then would prevail and totally dominate the region. They would remain as the fittest, but with the presence of the newcomers that very darwinian theory was reversed and that meant

${ }^{100}$ As quoted in Ibid., 76. 
that white mates black in very few moves according to Eliot. The commissioner's confession bared enough evidences for the FO to clearly understand Eliot's intention of again bypassing all African rights without any remorse, to create a country of white settlers. Specifically, he envisioned how ideal it would be to see a final solution for the Maasai threat. Eliot predicted that the mere presence of the Maasai in the highlands could trigger a clash with the arriving settlers aspiring to find good land. He also pointed out that it could be a bloody affair of the same magnitude as the Jameson raid. ${ }^{101}$ Eliot's reference to the Jameson raid sounded like a recipe that could well suit the case of the Maasai occupying valuable land suitable for European colonization. Eliminating the Maasai would not even have a repercussion worthy to be mentioned in the annals of African history.

Eliot never seemed to fully understand how history would record a sudden extinction of the whole Maasai community without digging into the origins of such a tragic event. If that was the case in history, archeologists would sure dig deep and ask questions about the dark history behind such a crime scene. It does not take an extraordinary mind to realize that history would also have to write about how that terrible tragedy happened? Who were the perpetrators and what were their motives? The answer to that historical query would simply be: land alienation and greed at the expense of simple African people who never asked for a railway to be built in their country and neither wanted to see some alien non- residents come and take their land by force. If force could not be used to alienate land, there was another alternative. Legally agreed land leases' on easy term would mean alienation as well. In the case of

${ }^{101}$ Ibid. 
Messrs Chamberlain and Flemmer, if Lansdowne firmly rejected their land deal that could cause a scandal with grave legal ramifications that would sure get the attention of parliament. As the syndicate land deal was approved, Eliot then considered it unfair not to let Chamberlain and Flemmer have their reward because after all they helped in bringing settlers in the region. Eliot was now an empty bag of policy formulation and sought to blame everybody but himself.

The commissioner went on to blame Hill, who was the head of the APD, for his lack of competence and full assistance to him in his mission of land alienation. He underlined to the FO that Hill was quarrelsome and not even apt for the job of managing the APD. Eliot revealed that Hill confessed to him how he had respect and admiration for Coronel Ternan, who served as Deputy Commissioner in the Protectorate after Hardinge's departure and before the arrival of Eliot, and how he acknowledged that that decorated military servant was a better choice for the APD. Following the negative critique directed to Hill, the unrepentant commissioner called it quits by officially resigning in a letter where he wrote how he really felt, not his violations. He put it this way:

I have put my back against the wall \& if I cannot give Europeans justice \& if I cannot receive from your Lordship that confidence and support to which position entitles me, I am determined to go. I can hardly exaggerate the bitterness or the regrets which I feel in thus leaving East Africa. It was my hope to devote my life to giving it the position in the world which it deserves and I am conscious of having made a good beginning but I would rather leave it than be forced to manage it under the trammels imposed by those who have neither the knowledge nor impartiality. The Evil of East Africa is that it is not managed by your Lordship or by the F.O. as a whole but by a Department. It is impossible for you to devote time to it yourself: the work lies apart from general business in London and it has lost touch with reality out here. ${ }^{102}$

${ }^{102}$ As quoted in Ibid., 77. 
Eliot's resignation letter underlined the importance of giving justice to European settlers and that translated into accommodating them on the highlands and paramounting their rights in the protectorate. He criticized every department in relation with the protectorate and its officials but himself. It was really the commissioner's general attacks on everybody and specifically on Hill that bitterly ended his political career in the protectorate. After Eliot's deluge of criticism, and blame, it was time for the APD head, chief of all affairs as Eliot underlined it, to methodically formulate his response, and that was going to totally dismantle all the commissioner's case.

Sir Clement Hill, as head of the APD, had access to all the correspondences going to or coming from the EAP. Not only that, he assumed the responsibility of analyzing and interpreting them for the Foreign Secretary who apparently did not have the will to spend his hours dealing with the internal problems of an infant protectorate. Hill then gathered all the primary dispatches that Eliot ever sent during that ugly episode of complaints followed by his resignation and cross examined them carefully. The dispatch of Eliot's damaging confession about how he viewed the Maasai was a document of immense importance for Hill when it was his turn to defend himself. Conveniently, Hill used that confession document, as if he himself truly believed and cared about the importance of the protection of Maasai rights to land. Paradoxically in 1904, it was proven that Eliot's departure did not prevent the signing of first Maasai treaty that meant direct interference with the transhumant activities of the Maasai and the shrinking of their ancestral land. It was indeed very hypocritical for Hill to have used what Eliot wrote to make his case, to an extent; Eliot at least truly believed in what he wrote and worked consistently to alienate Maasai land. Hill was aware of the fact that if 
the dispatch was fully published, it would have a great impact at home by awakening all kind of public opinion reactions. ${ }^{103}$

Hill meticulously explained to Lansdowne all the possible negative consequences that could derive from Eliot's dispatch and its dangers. Hill referred to a potential scandal of great proportion that could spread like wild fire within the press at home. $\mathrm{He}$ then socratically presented to Lansdowne the case of what could be the resulting implications of a moral response to all these following questions.

Is it likely that a Commissioner with such views will seriously try to do his duty and control the settlers? Is it just to oust the Masai from their ancestral lands because the latter are good to the eye, and because we chose to run a railway through them - not to develop those lands but because they are on the shortest route to Uganda? Is it expedient at this moment to risk a native rising and the massacre of scattered settlers, to say nothing of the slaughter of natives which would ensue? Is it politically wise, in the face of public opinion at home, of the international obligations imposed upon us by the Brussels Act and of our discussions with the Congo State, to take a step which will lay His Majesty's Government open to serious charges of indifference to native rights which it will hard to refute? And for what objects? To make revenue a little faster; to please South African settlers or speculators who are already hawking their grants in South Africa markets; to save the Commissioner's amour proper; and perhaps to avoid claims for compensation arising out of his premature action. ${ }^{104}$

Hill's strategy worked well, no official would like to face parliament to answer to those delicate questions about the violation of African rights. As the whole problem facing the EAP was Eliot's failure to plan well in administrating the budget, Hill convinced Lansdowne about the fact that the commissioner had no reason threatening to resign. Hill won the battle of minds. His proximity with Lansdowne gave him advantage. Eliot's resignation was accepted. It could be interpreted as such, meaning a resignation of Eliot based on principles and pride, or as an action taken by the FO in

\footnotetext{
${ }_{103}$ As quoted in Sorrenson, Origins, 78-79.

104 Ibid.
} 
order not to lose control of the EAP. Nevertheless the protectorate was already turning into a political circus maximus with the few settlers already present in the region aspiring for power. When news of Eliot resignation reached the settlers' community in the protectorate, opinions about the well educated, disciplined and reserved commissioner started to change. The settlers now re-embraced Eliot. As Sorresnson put it: "According to Grogan, the settler feelings were so high that they intended to call for Eliot's resignation. When they realized he had resigned on their on their behalf 'everyone realized he was right', so they demanded an inquiry into the circumstances of his resignation."105

The settlers' support and sympathy towards Eliot took a new hype after his resignation. On one hand, settlers considered Eliot as their defender, a man who stood for their rights and would be missed. To say the least, that was quite a strange legacy of Eliot's administration. The man on the spot made his mark in the protectorate. The settlers organized him a well deserved dinner at the Mombasa Club before he left the EAP for good in July 1904

\section{$\underline{\text { Conclusion }}$}

The arrival and settlement of the Europeans in the EAP was the ongoing work of the commissioner. In less than four years, the EAP saw the introduction of a conflictive group of people who not only wanted to alienate the best land, but also usurp political power. Their major obstacle was that they represented but a miniscule fraction of the EAP's population. Therefore, the powers-that-be in London could hardly consider that such a minority could be solely entrusted to develop the region. As the FO was still

105 Ibid., 80. 
concerned with the question of how to quickly recover the Empire's investment in the railroad, and perhaps even show a profit from it, the commissioner insisted that the best way to lift the protectorate was through perpetuating the influx of European settlers and investment throughout East Africa. Nevertheless, not all the colonists who arrived were able to establish themselves without the support of the local administration. The "big men" were able to benefit from large alienated areas of land, but found it difficult to develop this acreage without African labor. Legal land survey, acquisition and development became subjects of intense debate at the FO. Eliot started his administration with the wrong approach, insofar as a discriminatory system within a British colonial protectorate was not going to prevail without political repercussions at the FO, ultimately responsible for supervising the region for the benefit of all His Majesty's subjects.

The commissioner pointed the way to the newcomers who thought of running the protectorate along the model of South Africa, where the rights of the Africans were ignored. With Eliot's backing and the settlers' nature and aspirations, the stage was set for a long political struggle in the EAP. Eliot's legacy upon the protectorate would later have far more political consequences. An economic plan of development based on race and excluding the Africans and the Indians was being hindered at every turn. Nevertheless, with Eliot's administration, the stage was already set for political conflicts. The latecomers had their agenda, which was not suitable for the EAP; but they were determined to carry on with their dream of achieving- sooner or later- a self-governing country. The FO was being overwhelmed with news of the settlers' demands for the best lands and racial privileges. Changes were sorely needed for an equal and fair society. With Eliot's resignation, the EAP was to enter a new phase. Stewart was appointed 
commissioner; and in 1905, the Colonial Office (CO) took over the protectorate to the relief of the FO, an agency whose officers found themselves too busy for dealing with the entire minutia continually popping up in the troublesome protectorate. 


\section{Chapter 3}

Shifting Gears: A new man on the spot, Colonial Office Takeover and European Settlers' first Politics demands

" The question just here is not whether we are governing those colonies and subject races well and wisely, better than they could govern themselves if left alone, or better than another imperial European nation could govern them, but whether we are giving them those arts of government which we regard as our most valuable possessions."106

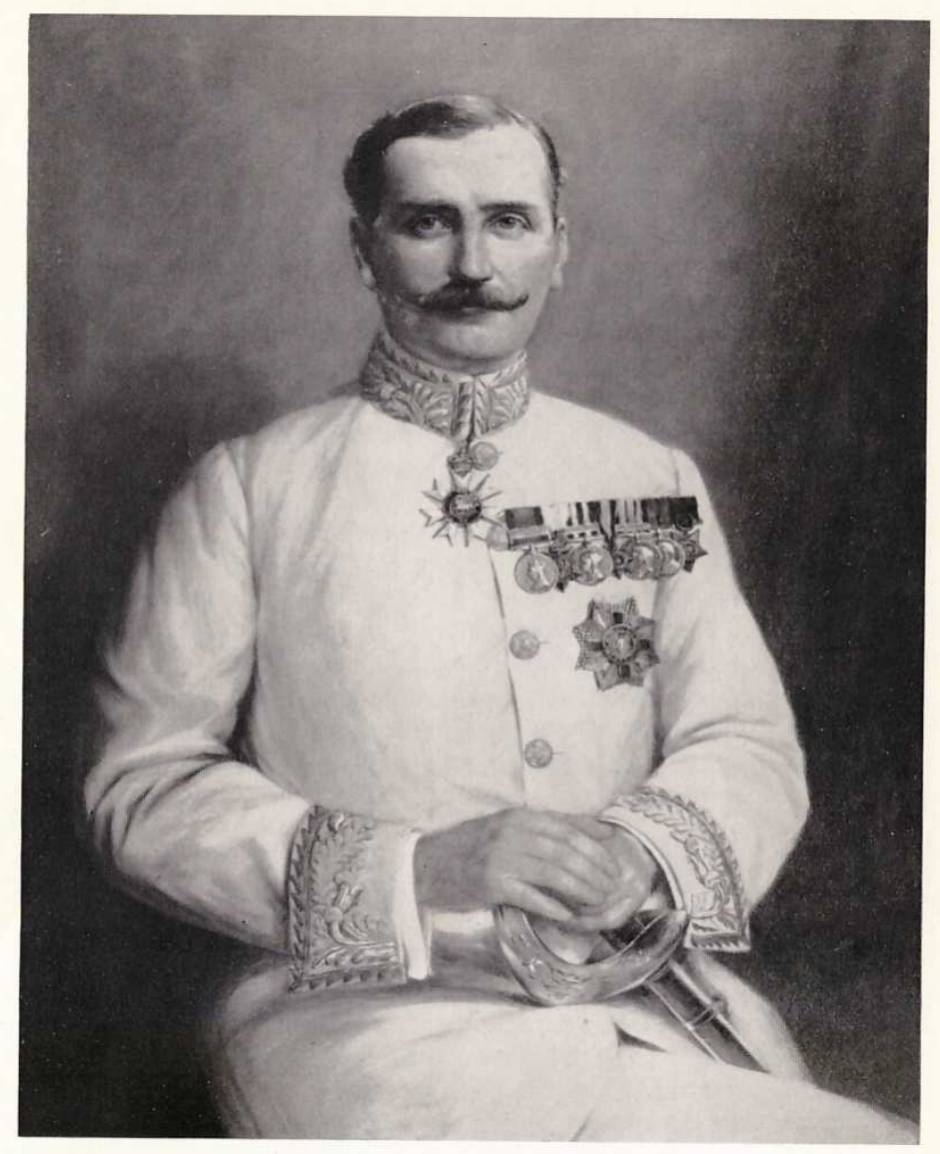

SIR DONALd STEWART

Image 5: Sir Donald Stewart. Source: Mungeam, British Rule, 116.

106 J.A. Hobson, Imperialism: A Study (London: George Allen \& Unwin, 1902), 117. 
Introduction

In July 1904, Sir Donald Stewart ${ }^{107}$ succeeded Eliot as commissioner of the EAP upon recommendation of the CO. The new man on the spot already had experience with matters concerning white settlers on the Gold Coast. That experience was to be valuable in the handling of the political situation evolving in the protectorate. The settlers that Eliot invited arrived and were pressing persistently for large land concessions. This became a big issue with the Land Committee appointed by Stewart. The FO instructed Stewart to pay special attention to the relations between the Africans and the latest white arrivals in the protectorate. Even after Eliot's departure, the FO was still concerned with the possibility of the European settlers' takeover of the best land on a massive scale.

W. McGregor Ross emphasized that "the story, so far, has been one of the occupation by some Europeans of the property of African natives, and this with the assistance of Government, and the settlement of other Europeans upon vacant land to which Government gave them not only safe access but also secure titles." ${ }^{108}$ That created a problem that Stewart inherited and had to resolve. Ross asserted that, "the Government created a caste of landed proprietors a privileged class. Its members can certainly not be blamed for accepting the chances of wealth which a British Government placed before them." 109 The settlers whom Churchill called "political animals" were

107 Captain Sir Donald Stewart was a military man who served the British Empire fighting wars in Afghanistan (1879-1890) and Transvaal (1881). He also served in India (1882-1884) and the Gold Coast (1897-1904) before being appointed as Commissioner of the East Africa Protectorate. He was always ready for punitive expeditions against an African group threatening to challenge the colonial grip on British East Africa. Stewart's tenure in the protectorate was short lived. He died in 1905. M. P. K. Sorrenson, Origins of Settlement in Kenya (Nairobi: Oxford University Press, 1968), 84. 108 William McGregor Ross, Kenya From Within (London: Frank Cass and Company, Limited, 1968), 68. 109 Ibid. 
ready to fight for their interests. In the midst of this new situation created by Eliot, Lansdowne reiterated that Great Britain had a moral obligation in looking after the welfare of the native population of the protectorate. He told Stewart that: "The first question which must engage your attention on your arrival in East Africa is that of the relations between white settlers and natives, more especially in those regions between Nairobi and Lake Victoria which present a possible field for European colonization on a large scale ... On its proper solution the future of the Protectorate will largely depend."110 That had to be a priority in Stewart's administration of the protectorate

However, the European settlers had their own idea about how the protectorate should be run. Talks of the primary interests of the newcomers were long entertained by Eliot and the European settlers even before Stewart's arrival.111 It was not a surprise when, in 1905, after the transfer of the protectorate to the $\mathrm{CO}$, the CA presented their first demands. They desired a LegCo containing elected members and a crown colony. Since it was their first general political statement, it is important to analyze it well. Their aspirations gave birth to a struggle about the control and administration of the EAP. In analyzing the loss and reassertion of imperial initiative in the EAP that later became Kenya Colony in 1920, Maxon raised a significant issue that the CO faced. Maxon explains that "the Colonial Office in London struggled to maintain initiative and control in these years in the face of several, often contradictory parties and pressure groups; among the most influential were Kenya's colonial state, the European settlers

\footnotetext{
${ }_{110}$ Lansdowne to Stewart, 8 July 1904, FO 2/833.

${ }^{111}$ G. Bennett, "Settlers and Politics in Kenya, Up to 1945," in History of East Africa, vol, 2 Vincent Harlow, et al, eds. (Oxford: Oxford Clarendon Press, 1965), 265.
} 
and the Indians residing there, the India Office (IO) and the government of India, missionaries, humanitarians, and capitalists in Britain itself." 112

The root of the problem that Maxon stated took shape early when the CO took over the protectorate and when the European settlers articulated their first demands in 1905. As soon as the settlers' demands went public, different positions and opinions started to emerge from the protectorate and London. The CS and the CO were both involved. Lord Hindlip supported the settlers in England. There were also the responses of Sadler, who succeeded Stewart as commissioner in 1905, and other officials as well as the reaction in London. It was under this political turmoil that a Legco and a new constitution for the EAP were agreed upon. The settlers had pressed for the transfer of the protectorate to the $\mathrm{CO}$, believing that it would lead to a more sympathetic and less miserly administration. They had their demands on the table and had to deal with a new commissioner. This is the setting of this chapter, the purpose of which is to bring light to the nature of the early political struggle in the protectorate, sparked by the presence of the European settlers that Eliot attracted there. They came to settle and fight for what they believed was their right to rule the protectorate based solely on their own interests.

\section{$\underline{\text { Stewart's administration and the European settlers' influence }}$}

The appointment of Sir Donald Stewart as commissioner was the result of Eliot's precipitate resignation due to the fact that he was stymied in his plans to assist the white settlers he had invited to the EAP. Mungeam gave the following evaluation of the former commissioner's administration, emphasizing that:

\footnotetext{
${ }_{112}$ Robert Maxon, Struggle for Kenya (London: Associated University Presses, 1993), 13.
} 
Although Eliot had only been Commissioner for three and a half years, he had clearly made his mark upon the Protectorate. He had taken over a country in the throes of revolt, and had seen a measure of law and order established, and frontiers extended. Most important of all, when faced with the need for quick return to pay for the railway, he had turned to the deliberate encouragement of expatriates. Through the introduction of the settlers he hoped to secure the rapid results that he believed the local Africans to be incapable of achieving by themselves. ${ }^{113}$

Eliot administrated the protectorate with a firm belief that Africans were incapable of developing the region and preferably should work as squatters in white men's farms, leaving the public square to the European settlers. Eliot was the progenitor of European settlement in the EAP and pushed for an establishment of a white man's country in the highlands of the protectorate, thus undermining the rights of the Africans and the Indians altogether. Eliot discredited the highest office of the protectorate with his own unfair policy that tended to favor the settlers who wanted free or cheap land, more political recognition, and participation in the internal affairs of the region.

Eliot's plan did not sit well with the FO because any flagrant violation of African rights would make it difficult and even more embarrassing for His Majesty's Government to justify their presence in the EAP. For that reason, Lansdowne did not want to allow any more grants of large areas to individuals or syndicates although he was aware of the presence and continuing arrivals of expatriates who answered Eliot's call. ${ }^{114}$ An adequate land survey was needed to prevent speculation and accumulation of land by a few settlers with capital. The firing of Eliot, followed by the rapid appointment of Stewart, was a strong statement from the FO. The FO's intervention meant that London was still in charge of maintaining initiative and control of the protectorate in its early stage under British rule.

${ }_{113}$ G. H. Mungeam, British Rule in Kenya, 1895 - 1912 (Oxford: Clarendon Press, 1966), 115.

114 Lansdowne to Eliot, 8 July 1904, FO 2/833. 
Although Eliot was sacked, it remained clear that he made a lasting mark upon the protectorate by setting the stage for a tense political atmosphere that prevailed after his departure. It was under his tenure that the EAP was becoming a hodge-podge of disparate ethnic groups, with the settlers scurrying to protect and advance their interests under London's supervision. That was an important aspect of Eliot's legacy that carried within itself a ripple effect with which Stewart had to deal. The troublesome relationship between Eliot and the FO about how to run the protectorate had a lasting impact in the executive office of the EAP before Kenya became a colony.

For the first decade of the EAP's administration, a series of weak or pro-settlers' rights commissioners, and later governors, occupied the office and had to deal with the European settlers' agitations and ever-increasing political demands. Stewart was the man appointed by the FO to assess and control the situation in the EAP in 1904 and was not the last one. Finally, Stewart's arrival also meant that change was needed and following Eliot's footsteps was not the right way to proceed.

Stewart was called upon to run the protectorate because of his extensive military background and his experience in the Gold Coast where he dealt with other Europeans looking for wealth. The $\mathrm{CO}$ considered him as a man well-suited to administer the EAP. His military background made him appear as the right man to continue potential military expeditions on the frontier. At a time when Britain needed to strengthen its grip on the protectorate, Stewart's credentials made the CO's recommendation of him to the FO seem justifiable.

The FO had the habit of shuffling officials from one colony or district to another without first considering if experience gained in another British territory would be valuable in the context of the EAP with its troublesome settlers, the majority of whom 
came from South Africa. It was along that trend of decision-making that stimulated the FO to send a man with military experience to administer the EAP. Some officials like Alfred Claud Hollis, who served directly under Stewart, and interim Deputy Commissioner C. W. Hobley, expressed their opinions about Sir Donald Stewart. Hollis noticed that the new commissioner "was a very different type of man from Sir Charles Eliot. Sir Donald Stewart was a soldier. Though indolent, he was a disciplinarian, and he thought that no country could be properly administrated until (to use his own phrase) the natives had been "knocked into shape." 115 He loved action in the vast wilderness far more than the details of administrating the problematic EAP. While Eliot, the educated diplomat, did not socialize with settlers, officials or military personnel during his tenure, Stewart was "a better friend to the military than to his officials; he frequently dined in their mess, and took part in 'cock-fighting' after dinner." 116

Stewart was better-suited for a mission of pacification of the Africans than for the task of having to deal with correspondence or with how to turn the protectorate into a profitable enterprise. Stewart was content to intermingle with other army officers who also welcomed the idea of the need to control the region by no other means but the use of force on the Africans. They also enjoyed chasing after the Africans literally, for to them, it was a game of a bloody punitive expedition that could earn them promotions. ${ }^{117}$ Hobley, a long-serving official who was transferred to the EAP from Uganda in 1902, was quick to notice the character of the new commissioner. Hobley described

\footnotetext{
115 Quoted in Mungeum, British Rule, 116.

116 Ibid., 117.

${ }_{117}$ Ibid., 127. Mungeum notes that early administrator Francis Hall specifically complained of this attitude among the military.
} 
Stewart as "a man of considerable force of character and shrewd common sense, but without business experience or training, except perhaps in the racing world. He was what might be termed an illiterate man, having no knowledge of other than of the good side of life. His powers of application were underdeveloped; he rarely read files, and as he went to bed late and rose late the affairs of the country had scant attention." 118 Stewart was a military commander who adopted a militaristic approach when he had to deal with the day-to-day office work. He simply relied on his subordinates like Hollis to do the administrative tasks while being loyal to him. Policy formulation was difficult and confusing for him.

When it came to matters related to the presence and interests of European settlers in the EAP vís a vís African rights to land and self-assertion, both the $\mathrm{CO}$ and the FO did not do their homework before agreeing to send Stewart as the one qualified to administer the protectorate. This was due to the fact that in the context of the EAP, Stewart's experience with European settlers in the Gold Coast was not much help. Stewart was not a bureaucrat, a good negotiator, an economist or a politician who could devote enough time to European settlers' grievances along with the need to turn the region into a profitable area for Britain. Stewart was not prepared to deal with the settlers' agitations and their push for political aspirations. He had no valuable experience that could help him for the social, political and economic challenges ahead.

The Europeans that Stewart dealt with in the Gold Coast were different from the settlers that Eliot invited in the EAP. Settlers in the EAP had a reputation of being political animals and go-getters who imbibed prejudice. In contrast, Europeans in the

${ }_{118}$ C. W. Hobley, Kenya from Chartered Company to Crown Colony: Thirty Years of Exploration and Administration in British East Africa (London: H. F. \& G. Witherby, 1929), 127. 
Gold Coast had different goals. They were not after land and power. They were not inclined to own land there, as it was the case in the EAP. European gold traders were not allowed to own land. The Concession Bill of 1900 required the Europeans to pay rent to the chief or the community that owned the land. In the Gold Coast, as its name indicated, gold was what the Europeans were after. The gold-mining industry justified the presence of only a few Europeans, who were gold traders and were not permanent settlers aspiring for self-government.

In addition to that fact, Europeans in the Gold Coast could not successfully settle in the interior of the region. In any case, the interior of the region from the western coast of Africa was inhospitable for many Europeans and it had a reputation of being the white men's graveyard. This was largely due to the intense presence of malariavectoring mosquitoes. There were other factors for white Europeans not to attempt settlement there. In the Gold Coast, there were no speculations about the right economic direction to follow, because local production for export rested in African hands. ${ }^{119}$

In contrast, the main economic concern in the EAP was how to make the protectorate pay for the railroad's construction cost first and when faced with that need the departing commissioner Eliot called upon the European settlers. Taking into consideration the settlers' readiness to defend their interests through their political organizations, it remained clear that the FO rushed into judgment by appointing

\footnotetext{
119 Export production by African peasants was a system virtually untried in tropical Africa at the beginning of the twentieth century. However, it was better suited to West Africa than to East Africa because control over many East African people was still progressing, though tenuously. In the EAP there seemed to be more physical space for European settlers without damaging African rights. That was the estimation at the time, which later proved untrue. C. C. Wrigley, "Kenya: The Pattern of Economic Life 1902-45," in History of East Africa, vol. 2 eds. Vincent Harlow, et al. (Oxford: Clarendon Press, 1965), 229.
} 
Stewart. The FO threw him in the midst of an evolving political struggle with the unavoidable question of African rights versus European settlers' interests.

Stewart did not know the kind of settlers that were waiting for him in the EAP. Some valuable government officials who had been serving the protectorate since the early days of the Imperial British East Africa Company reported on the spirit and nature of the settlers present in the EAP. ${ }^{120}$ The latter were prejudiced in general. In addition to that reputation, some of them were aggressive land grabbers, speculators and politicians who thought that Eliot fought for their rights to own land and was wrongly crucified by the FO. The expatriates came to believe that any official sent by London to administer the protectorate should stand up to the FO, which was later replaced by the $\mathrm{CO}$, and advocate for their interests. They came to believe that every commissioner was another white man like them who should join their side as they felt Eliot did during his tenure.

After lamenting Eliot's resignation, they were anxious to know whom the FO would appoint and how the new man on the spot would run the protectorate. Among the most eager to know about the new commissioner's plan to run the protectorate were the radical settlers, vocal and volatile minded go-getters like Grogan, Delamere and also aristocrats of the class of Lord Hindlip, who vowed to defend settlers' interests anyhow and anywhere. Delamere especially stood for the protection of the European settlers interests.

${ }^{120}$ Eliot to Lansdowne, 19 Dec.1903, FO 2/807 as cited in in Sorrenson, Origins, 68. The serving officials in the protectorate like Ainsworth, Hobley and Jackson defined the European settlers as a "hard caste to deal with." See also W. R. Foran, A Cuckoo in Kenya (London: Hutchinson, 1936), 96. This friend of the South Africans described them as "an exceptional stamp of colonist, accustomed to taking and giving hard knocks in life ....” 
In 1903, Jackson, who was Eliot's Deputy Commissioner, noticed the rapid increase of Delamere's political influence in the protectorate. Delamere, whom Jackson regarded as another "scalliwag" from the settlers' camp, was rubbing shoulders with Eliot and seeking governmental support. ${ }^{121}$ With Eliot and Delamere's entente, all political maneuvers were to encourage and benefit the settlers in the protectorate. However, from the beginning of Stewart's administration, Delamere was skeptical about the new administrator and this time, Hollis took notice.

Hollis revealed that Delamere was not enthusiastic to meet with Stewart. According to Hollis, Delamere had his doubts about Stewart's sympathy towards his compatriots. Delamere confessed to Hollis that he "never knew when he went to Government House whether the A.D.C. would be instructed to give him a whisky and soda or to kick him down the steps." 122 This was a red flag. It signaled the potential opposition of Stewart to settlers' interests in the EAP. Stewart could meet the CA's leader's demands with a strong response. At the beginning of his mandate, the new man on the spot found it unnecessary to deal with the settlers' nonsense, as he viewed it. Stewart wanted to enjoy life with his military peers in a beautiful part of Africa with its agreeable climate.

The character of the new commissioner, who did not put up with nonsense from the settlers, paradoxically set the stage for an upcoming political struggle with settlers who were determined to use their influence to gain power. A strong commissioner was needed to evaluate the situation and to stop possible arbitrary land alienations and violations of the Africans' rights. However, having a strong man in charge that could

\footnotetext{
${ }^{121}$ Jackson to Sir Clement Hill, 25 May 1903 and 4 August 1903, FO 2/720.

122 Mungeam, British Rule, 116.
} 
slow down or derail settlers' political agendas and promote African rights had its consequences. Any commissioner or governor sent by London to stand against the settlers' attempt to politically dominate the EAP faced the expatriates' agitations and pressures. The settlers had no moral concerns for the well-being of the Africans and the Indians.

Stewart was about to face a group of European settlers who believed in the possibility of building a white men's country at the expense of the Africans. That meant pushing for transition to a self-governing dominion. Reproducing the South African model of self-government was considered feasible to many European settlers who responded to Eliot's call by moving to the protectorate. Eliot's vision of establishing a white man's country was parallel with the European settlers' expectations of reaching a status of a self-governing dominion.

The first step of the settlers, though not directly political, was to have ownership of the protectorate. That passed for owning land a priori. For many expatriates, acquiring the best and largest portion of land in the highlands was a matter of an undeniable right, sine qua non for a successful settlement. They thought themselves entitled to occupy the highest echelon of the new social context and wanted land to be granted in freehold. That was the mindset of most of the settlers who came to stay. Lansdowne instructed Stewart to pay careful attention to the evolving situation with the settlers' objectives and more importantly, the issue of land. Lansdowne recognized that although the settlers' presence in the protectorate was a reality to accept, the idea of 
prioritizing their rights in the midst of a region dominated by the presence of Africans and Indians would not be a popular one in London. ${ }^{123}$

Stewart was instructed, therefore, to focus specifically on tasks related to the mainland. His duties were many. He was to administer the protectorate while having the responsibilities of dealing with internal affairs, especially with regard to arriving settlers requesting land, while also serving as the Agent and Consul General for Zanzibar. Lansdowne hired Stewart "as Commissioner and Commander-in-Chief" of the EAP to attend to the relations between Europeans and Africans in the Highlands. ${ }^{124}$

The presence of the settlers in the interior brought the need to limit the task of the commissioner who had to contain a big political crisis in the making. Separation of power through decentralization from the coast to the mainland meant that the FO finally "recognized the increasing settler influence on the mainland, and the necessity of employing a man experienced, to some extent at least, in African conditions and European pressures at first hand."125 Despite the FO's acknowledgment of the situation in the protectorate, Lansdowne believed that Stewart was up to the task.

Lansdowne gave specific instructions to Stewart underlining this contradiction.

How best to harmonise their indisputable rights with the requirements of white settlers is a problem which will require your closest attention .... It is only by a most careful insistence on the protection of native rights that H.M.G. can justify their presence in East Africa, and the imposition of the taxes which are levied from the natives on the grounds of such protection .... The collection should be exercised with the greatest care, for whilst the development of the Protectorate revenues is of great importance on behalf of the taxpayer of this country, the primary duty of Great Britain in East Africa is the welfare of the native races. ${ }^{126}$

\footnotetext{
123 Lansdowne to Stewart, 8 July 1904, FO 2/833.

124 Mungeam, British Rule, 117.

125 Mungeum, British Rule, 117.

${ }^{126}$ Lansdowne to Stewart, 8 July 1904, FO 2/833.
} 
The instructions Stewart received suggested that he had to do his best to make co-habitation possible in the interior of the protectorate. For that to be possible, securing equal rights and justice for all people in the protectorate was fundamental. Despite Lansdowne's good intentions to advocate respect of the Africans' rights, as noted above, no efforts were made by the FO to follow up with that ideal. The FO failed to publish Lansdowne's instructions that insisted on the necessity to look after the welfare of the Africans. That was supposed to be the definite policy to follow in the EAP, but reconciling African rights with the interests of the expatriates trying to take over the protectorate was difficult. Thus it was clear that administrating the protectorate was a complicated mandate for Stewart because of the difficult nature of the European settlers. Although the instructions of the FO to the new man on the spot seemed logical on paper, executing them was a monumental task. The reason for that difficulty centered on the fact that the real priority in the EAP was the need to generate revenue from the railway activities.

With the need to turn the protectorate into a profitable enterprise and to pay for the railways project, unnecessary expenditures had to be cut. Economy was to be practiced rigorously and that required the participation of the Africans and the Indians as well as the settlers. Nevertheless, with the superior attitude and the political background of the settlers, all expectations of rapid economic development were hampered. The presence of the settlers was not a guarantee for peace or prosperity in the region. It was rather the source of a perpetual political struggle that slowed any potential economic development. In the EAP, as Wrigley stated, "everything then 
pointed to European- directed agriculture, and thus to European immigration and European rights in land."127

The European settlers wanted large blocks of land to be set apart for their needs. The settlers' expectations to obtain land in the best areas of the protectorate were illustrated in the Maasai move, which was a direct consequence of their presence. Mungeam pointed out that: "Of all the problems connected with settlement, Lansdowne recognized that the most pressing was of the Masai. He admitted that the entry of settlers into their grazing grounds was likely to produce friction, and recommended that Stewart should make his own investigation of the position. On arrival in East Africa he should consult with local officials and with the Masai leaders, and report his conclusions to Lansdowne so that His Majesty's Government may reach a decision.”128 In fulfilling this charge, Stewart relied on the work previously done by Hobley, who negotiated with the Maasai and convinced them to move into reserved areas. As much had been done already by Hobley, and therefore Stewart did not want to complicate his work with extra investigation and papers.

To Stewart, the prospect of the Maasai move was a done deal. According to Mugeam's account: “Hobley, as Acting Commissioner, had prepared a series of papers which he laid before his new chief. In these Stewart found that as early as December 1903 Hobley has been brought down from Kisumu to Naivasha to be in charge of the Naivasha Province, and to study the whole Masai question. In company with Masai elders Hobley has embarked on a series of tours in the Rift Valley, and as result of the

127 Wrigley, “Kenya: Patterns of Economic Life," 214.

${ }^{128}$ Mungeum, British Rule, 118. 
investigations, he recommended (with Ainsworth's support) that the Masai should be moved to a reserve of their own on Laikipia plateau to the east of the Rift Valley."129

As a result following Stewart's arrival in August 1904, both Ainsworth and Hobley presented him with the removal plans for the Maasai. Stewart, therefore, relied on the advice of these two who had been working on the project. In the discussions in Mombasa and Nairobi with the Maasai, Ainsworth served as the liaison, even though his knowledge of the Maasai language was probably minimal, at best. In any event, a final treaty with the Maasai elders was achieved, to which Ainsworth served as a witness on behalf of the EAP. Taken altogether, the final agreement was much in line with Ainsworth's original proposals. He could rightly be considered as the prime mover in the Maasai settlement scheme. ${ }^{130}$

This was the best thing that Ainsworth, along with the assistance of Hobley, had thought of: the safeguard of the Maasai rights, because their land was subject to total alienation, with the settlers as potential beneficiaries. Carving reserve lands was thought to be the best option for the survival of the Maasai pastoralists. The quickness with which the situation was dealt with took the FO by surprise. To the FO, all information indicated that the Maasai were being rushed into a reserve, but that did not stop the concretization of the move. The case of the Maasai move was the first example of how reluctant Stewart was to deal with the internal problems that the protectorate was facing with land being a major issue.

129 Ibid, 119.

${ }^{130}$ Robert M. Maxon, John Ainsworth and the Making of Kenya (Lanham, MD: University Press of America, 1980), 148. 
$\underline{\text { Stewart, the Land Issue and the Colonial Office Takeover }}$

Stewart's passivity lent itself to exacerbating the ever-growing land issue in the protectorate. Stewart did not want to dedicate too much of his own time investigating the matter of land laws and their administration. This, in his opinion, would be a task better suited to a committee, which he duly constituted on October $31^{\text {st }}, 1904$, for the purpose of enquiring into and reporting on the following questions related to land in the EAP. The terms under which it was appointed appeared in the Official Gazette of November $1^{\text {st }}, 1904$.

The committee was specifically instructed by the commissioner to report on:

(1.) The general terms and conditions upon which sales and leases of Crown Lands should be granted.

(2.) The prices of Crown Lands.

(3.) The desirability of reserving lands for natives, Europeans and others.

(4.) The survey of land and the working and organization of the Land Office.

(5.) Native rights to or over land.

(6.) The rights of the Crown and individuals to and over land within the Sultan's dominions and elsewhere. ${ }^{131}$

Stewart also authorized "the aforesaid Committee to call witnesses and take such evidence as it may consider necessary and to add such persons to its number as it may think fit." ${ }^{132}$

At the outset, this committee was composed of three EAP officials: Judge R. P. Cator as chairman, along with Judge R. W. Hamilton as honorary secretary and Crown Advocate J. W. Barth. Of course, the members of the CA felt shunned and desired representation on the committee. The claim of the need to have representation in the land committee, although not loud yet, was indeed a crucial moment in the history of

${ }_{131}$ "Report of Land Committee, Presented to His Majesty's Commissioner, East Africa Protectorate, May 1905," in Great Britain, Papers Relating to British East Africa, House of Lords (HL) 158 (London: His Majesty's Stationery Office (HMSO), 1907), 5. 132 Ibid. 
settlers' politics in the EAP. It marks the beginning of the political struggle discussed earlier, with the constant settlers' interest factor, versus Africans' and Indians' rights in the region.

The problem stemmed from Eliot's administration. It was known that Eliot was the commissioner who invited and accommodated some settlers with a huge political zeal and pride. But, Stewart, without knowing it, was the one who provided them with an opportunity that led to the settler's adoption of an extreme political strategy.

The CA thought that any of their demands had to be met and they pressured the officials in the protectorate and the CO consistently. They were frustrated with the FO and some officials they thought were slowing them down. They wanted to build a successful new white men's country without hurdles in their way. The CA used the formation of the land committee as a political testing ground. Some members were ready to take action and stand for their aspirations. It was then under the pretext of the last clause of Stewart's reference that the association pushed for the nomination of Frank Watkins to serve in that capacity. Lord Delamere, because of his image and influence in the protectorate, joined the committee through the back door.

The committee went from three to five members but was reduced to four because Judge Cator was transferred to the High Court at Zanzibar. Nevertheless, upon leaving to his new post, Cator expressed his views on the matter of how to best create reserved areas for white colonization. Cator favored a proposition that suggested, "If an area in the highlands should be reserved for Europeans other areas equally suitable for agriculture should be reserved for Asiatics." ${ }^{133}$ That was a reasonable plea for the

133 Ibid., 15. 
Indians' rights to good land; but as noticeable in that proposition, the Africans' rights to suitable land for agriculture and pastoral activities was not mentioned at all. As a judge by profession, Cator seemed not to realize the importance of the question of protecting the Africans' rights in the protectorate. His transfer to Zanzibar opened the door for Delamere to promote the settlers' rights with a pro-settler land report.

Delamere quickly maneuvered himself into the chairmanship of the committee with little opposition. Apparently the others on the committee felt as if they were just going to fill some chairs and the committee work was only going to be another task they could gladly do without. Thus, Stewart's efforts of appointing a team to look at the land issue gave birth to a very pro-settler land committee. In regard to the whole situation, it appeared as though Stewart's lackadaisical approach to the land committee appointment resulted in his failure to inform the FO of Cator's needed role in chairing the committee. Therefore, the colonial authorities ended up shooting themselves in the proverbial foot by moving Cator to Zanzibar. That allowed Delamere to be able to exercise his influence by influencing and altering the result of the report for the settlers' interests.

With Delamere now chairing the committee, it was rather like the fox guarding the hen house. The committee went to work right after the formation of their team at the end of the year 1904. Although Stewart seemed to be collaborating with the settlers by entrusting them with a land committee of their choice, some settlers were not pleased with the new administration. Settlers' frustrations were constantly on a rise.

In The EAP, the most vocal settlers maintained and expressed their belief that the protectorate had the potential of being a profitable country. Their frustrations were directed to the FO. Mungeum noted: "In January 1905 A. G. W. Anderson, one of the 
leading European residents in Mombasa, addressed a long letter to the Colonial Secretary. In it he complained of the general system of administration within the Protectorate, of the type of men who served as officials, and the introduction of Indian systems of law and currency. He bemoaned the fact that Eliot-'a most able and upright Administrator'- had resigned, and expressed the hope that Stewart would also do all he could to entice the new settler into the country."134

Anderson's complaints reflected the early tension between the settlers and the officials in the protectorate. The settlers also blamed the FO for its passivity and lack of support for their cause. The settlers found the officials in their way as they attempted to dominate the protectorate by occupying the best land of the Africans and by standing against the promotion of the Indian traders. The settlers' perception of the officials' role in the protectorate led to a struggle that grew and caught momentum during Sir Percy Girouard's administration from 1909 to 1912 . The early European settlers' political strategy was to protest when official policy did not suit their interests. In such cases, the officials often received the full benefit of the wrath of the most extreme settlers, when some of their immediate demands they considered important were not met in time.

In the early days of the EAP the field officers were the pioneers of empire left in a difficult situation, as it was impossible for any official to do all that was needed or demanded by the settlers. "The East African administrator, unlike his counterpart in West Africa or Uganda, was faced with the task of achieving cheap government through African acquiescence, and at the same time of meeting the growing demands of white settlers. These demands placed a heavy strain on the native agents and collaborators, no

134 Mungeam, British Rule, 148. 
less than on the administrator. And amidst all his dilemmas, central policy offered nought for his comfort, because it remained both ambiguous and inconsistent."135 In the EAP, the presence of the settlers was a huge factor when it came to the right policy to follow to develop the region. The newcomers resented the ever-present shadow of some officials serving in the region and also bureaucrats, politicians and humanitarians who did not appeal to their cause in England.

Frustrated with the administration of the protectorate and the officials in place, the newcomers often bypassed the CS authorities. They did so by remaining active and made use of their association to push their agenda. The CA convened a special meeting in January 1905 to devise a political strategy for advancing change in light of the new circumstances. ${ }^{136}$ The action of the $\mathrm{CA}$ and Anderson's complaint to the $\mathrm{CO}$ were clear examples of how the radical European settlers' wing manifested their frustrations out of the protectorate. Nevertheless, the settlers' discontent was met with criticism in the $\mathrm{CO}$ by some officials. On 14 February 1905, CO official A.L. Antrobus opinionated on Anderson's complaint. He anticipated problems stemming from the settlers' camp in the EAP. Antrobus warned that: "I am afraid that all the people who, like this writer, Lord Hindlip and others, are finding fault with the Foreign Office and saying how glad they are coming under the Colonial Office, will not like us any better when we take over the administration." 137

Attitudes towards the FO supervision of the EAP left less to desire because progress was sluggish and the protectorate still was struggling to generate substantial

\footnotetext{
135 T. H. R. Cashmore, "Studies in District Administration in the East Africa Protectorate, 1895-1918" (Ph.D. diss, Cambridge University, 1965), 12. ${ }^{136}$ Bennett, "Settlers and Politics", 274.

137 Mungeam, British Rule, 148.
} 
revenue. The $\mathrm{CO}$ seemed to be the best alternative to supervise the protectorate and the settlers welcomed the idea of that very possible change with high expectations. The settlers hoped that a transfer from the FO to $\mathrm{CO}$ would be conducive to better overall administration of the EAP. More than any other group, the white settlers were expecting changes in their favor. They were looking for the new commissioner to formulate swift pro-white policies even in the face of opposition from some of the longstanding officials in the protectorate like Jackson, Ainsworth and Hobley. The settlers claim was not a new source of struggle because since Eliot's administration, they wanted land to settle down, land to develop, land for speculation and political power.

Regarding the EAP land policy, the $\mathrm{CO}$ had been sending warnings to the FO about the dangers of arbitrary land alienation. In July 1904, after an FO inquiry about the land application of two settlers (Woodhouse and Cameron) for 500 square miles of land in the Tana Valley, "the Foreign Office was advised not to grant more concessions until the land regulation were put on a more satisfactory basis. " 138 Despite the warnings, officials in the FO ignored the call for a measure of prudence when proceeding with issues related to land, specifically in an infant protectorate experiencing the increasing arrival of the so-called land-grabbers from South Africa. The CO's advice was seen by some FO officials as if it was a direct interference in their way of supervising the protectorate.

Sir Clement Hill, who was the superintendent of the African protectorates from 1900 up to his retirement in 1905, considered that a busy CO did not have much to say about the way business was conducted by the FO. In addition to that, "Hurst, who

${ }^{138}$ Sorrenson, Origins, 83 . 
drafted the 1902 ordinance, denied that any Colonial Office criticisms of his ordinance were valid: "It was working well as the local officials had not complained about it." He concluded that "until the C.O. take over the administration of the protectorate and have the opportunity of becoming acquainted with the facts, the assistance they can offer us cannot be of great value."'139 That was a response meaning that the EAP was too troublesome of a region to administrate effectively.

In April 1905, the CO was in charge of the EAP. The CO was very familiar with the issues that the FO was dealing with regarding the protectorate. A proper land distribution under the pressure of an increasing number of settlers applying for large concessions was a crucial issue with which the $\mathrm{CO}$ had to deal. Lord Hindlip, the British aristocrat, who clearly sympathized with the settlers, commented on the status of the protectorate. In his 1905 book, he argued that: "In East Africa you have a country where at present there are some five hundred white families; land questions are under consideration, the country is capable of supporting a large white population, and perhaps in the future it will rank among the food-producing countries of the world." 140 Lord Hindlip believed in the possible economic development of the protectorate conducted by the white settlers who were in fact the minority group in the region.

Lord Hindlip was even more enthusiastic about the end of the FO rule and had high expectations about the potential of the protectorate if the $\mathrm{CO}$ could collaborate and fully back up the settlers. Lord Hindlip welcomed the CO take over and stated that: "The country had emerged from the condition in which it was subject to the bureaucratic consular jurisdiction of the Foreign Office, and has passed under the experienced and

139 Ibid.

${ }^{140}$ Charles Allsopp Hindlip, British East Africa: Past, Present and Future (London: T. Fisher Unwin, 1905), 57 . 
enlightened rule of the Colonial Office." ${ }^{141}$ He also manifested a degree of satisfaction about the new commissioner's first step in his attempt to resolve the ever pending land issue in the protectorate. He acknowledged that "Sir Donald Stewart is working for the settlers' interests, and has even called meetings of settlers to discuss matters appertaining to the defense of the country; a Land Commission has been sitting, on which were appointed two unofficial members." ${ }^{142}$ McGregor Ross, on the othr hand, noticed the very beginning of a political pattern in the administration of the EAP that was based on taking into consideration the opinions of the few European settlers who simply wanted land and power. Ross asserted that "from the earliest days the Government of the East Africa Protectorate displayed commendable willingness to listen to advice from local European residents. Critics of a sardonic turn of mind might perhaps interject that it had no option in the matter, the advice having been tendered in such strident tones as to compel attention." ${ }^{143}$ The settlers' general opinion on how to best run the protectorate grew to become their own political agenda. White settlers' claims of the best lands in the protectorate were just the beginning of their struggle for the control of the protectorate. They also progressively sought to gain full political rights so that in a near future, they would have total control of the region. As noted earlier, these problems that the protectorate was facing were not new to the $\mathrm{CO}$, which was often consulted by the FO before the transfer was effective in 1905 .

Before the transfer, the FO did not seriously take into consideration the $\mathrm{CO}$ advice about "the dangers of speculation in land and urged not to alienate large areas in

\footnotetext{
${ }^{141}$ Ibid

142 Ibid.

143 Ross, Kenya From Within, 167.
} 
freehold."144 One clear example of how the FO conducted business was the case of the E A S's land application. Sorrenson pointed out: "One result of the Eliot-Hill controversy was a renewal of Colonial Office apprehension about the Foreign Office administration of the protectorate. There had been inter-departmental friction since 1902 when Hill and Hurst ignored Colonial Office advice in drafting the Crown Lands Ordinance," adding that in November 1903, when the Foreign office was in the middle of negotiations with the East Africa Syndicate, "the Colonial Office drew attention to unsatisfactory features of the ordinance and suggested a New Guinea ordinance of 1899 as providing useful safeguards for opening up a new territory." 145 Hill just carried on and pressed the Treasury to agree to the syndicate grant. That was possible because of Hill's influence and position in the FO. Also, in the midst of doubt about the effectiveness of the Hurst's land regulation draft of 1902, the protectorate desperately needed big investors with capital to help jumpstart the economy of the region.

It is important to underline that on one hand, Hill's scheme for the syndicate to obtain land was possible because the FO and the Treasury had no clear idea about how to pull profit from the infant protectorate. Hill's work for the Syndicate was then practical and justifiable because desirable capitalists were to be encouraged to invest. The expectations were that the Syndicate's deal was going to open the door for more European settlers with big dreams and ambitions to invest in the protectorate. On the other hand, Hurst believed that the drafted ordinance of 1902 was working well.

But, if indeed it did, it was because of Eliot, who relaxed the rules for the benefit of his favorite European settlers. The settlers considered the rules as too rigid and

144 CO to FO, 3 November 1903, FO 2/807.

145 Sorrenson, Origins, 83. 
against their interests. That was one of the problems that Eliot created and left for Stewart, the FO and later the $\mathrm{CO}$ to better sort out. Though the $\mathrm{CO}$ tried to point out to the FO the right way to cope with the issues of land and settlers who wanted to transform the protectorate into a white men's country, their suggestions were ignored. In fact, the $\mathrm{CO}$ was overwhelmed by the poor management of the FO, which left them with a mess to clean up.

The FO turned the protectorate to the $\mathrm{CO}$ and no steps to facilitate a smooth transition were taken. The FO did not keep the $\mathrm{CO}$ informed about the general affairs concerning the EAP. Just after the transfer, the $\mathrm{CO}$ officials realized that what they had inherited was a mess. As long as the FO was concerned, after ten years since the opening of the protectorate, all files were to be left in the disposition of the CO. It resulted that "Only one volume was needed to file all the correspondence on matters affecting the transfer, and this dealt more with routine questions than basic questions of policy. There seemed to be no evidence that Lansdowne and Hill ever prepared a comprehensive handover report for their successors." 146

The passivity and lack of diligence on the part of the FO upset Churchill, who was the colonial undersecretary in December 1905, following the formation of the Liberal Government. Churchill did not fall short in criticizing the FO for the chaos they left behind. He noted, "The organization of such territory was not a work with which the department was acquainted or in which they have displayed aptitude." Once again the need to shuffle officials for better supervision of the EAP was felt by the CO that held "no executive power" but, was able to "exert influence on policy through approval of

${ }^{146}$ Mungeam, British Rule, 136. 
colonial budgets, legislation, and appointments."147 It was deemed necessary to restructure the whole East African Department (EAD) administration with new faces.

\section{The Colonial Office Takes Over}

Before getting into the details of the policies and positions of the $\mathrm{CO}$, it is important to understand the initial changes that were made by the $\mathrm{CO}$ to better supervise the protectorate at the time of the 1905 takeover. Officials with experience from different British territories were called upon to form a team creating the EAD. According to Mungeam's analysis:

At the transfer a special East Africa Department was created with the Colonial Office, responsible for the Protectorate of East Africa, Uganda, and British Somaliland, and for the King's African Rifles. At its head was R. L. Antrobus, one of the four Assistant under secretaries in the Office, who also had responsibility for the West Africa Department and West Africa Frontier Force. Under Antrobus, in descending of seniority, were H. J. Read, drawn from the West Africa Department, W. D. Ellis, from the North America and Australasia Department, and W. C. Bottomley, also from the West Africa Department. These were joined on 1 January 1906 by R. Popham Lobb, seconded from service in West Africa in an acting capacity only. At the head of the officials, as Permanent Under-Secretary, was Sir Montague Ommaney.148

Following these initial steps of reorganization then underway in London with the transfer of the protectorate to the $\mathrm{CO}$, the white settlers in the EAP were beginning to feel as if there was some hope on the horizon, that maybe some in the $\mathrm{CO}$ would begin to at least listen to their demands. Two weeks after the transfer of the FO to the $\mathrm{CO}$, Grogan took the opportunity to make his voice heard about the status of the EAP which he considered a stagnant land of opportunity for the white settlers without a defined policy, paralyzed by incompetent officials and the lack of support from the Treasury. Grogan sent his frustrations to the editor of the Times in which he argued that:

147 Minute by Churchill, n.d., on Hindlip to Churchill, 22 June 1906, CO 533/25.

${ }^{148}$ Mungeum, British Rule, 136-137. 
In East Africa there is land sufficient to absorb enormous numbers of settlersland of first class quality, and owing to its various altitudes and rainfalls, suitable for the successful practice of every conceivable of the great primary industry; while the importance of a considerable concentration of British population on these highland plateau cannot be exaggerated in its relation to Imperial strategy. The underlying scheme of administration as initiated by the Foreign Office is essentially sound, but its lack of elasticity and the complete absence of Treasury response to the needs created by the sudden and rapid commercial awakening of the past year have induced what closely approximates to a complete breakdown in the administrative machine. The small staff which was considered sufficient to deal with a position the most important features of which were a few sporadically fractious natives and infinite hosts of antelope has suddenly been called upon to handle a rapidly developing colony with all its attendant problems of landsurvey, cattle disease, and, above all, control of the relations between well intentioned, unsophisticated natives and white wastrel flight, which invariably is the van of any movement of population to a new country.

The sole trouble is an absence of any clearly defined line of policy, and the lack of special knowledge of, and the organization to cope with, the problems which the unexpected awakening has evolved. This is due, not to any lack of local enthusiasm, but to a starved exchequer. On every side one sees not only that the country is severely handicapped, but that its future is actually imperiled by the local officialdom's fear of appealing to the stony heart of the Treasury. ${ }^{149}$

Within the $\mathrm{CO}$, however, some degree of pessimism with regard to the future of the EAP prevailed. Secretary of state Alfred Lyttelton was among this skeptical group. He seriously questioned the significance of the EAP within the context of the global British Empire. At best, the Protectorate could serve as an expanded "outlet for Indian emigration." 150 It is also clear that Lyttelton's men shared in the secretary's dour outlook on the EAP. There was talk among them of displeasure with the FO's prior concessions and land grants to settlers that had taken place under Eliot's administration of the EAP. In fact the appointment of a land committee by Stewart that was a response to the settlers' displeasures provided an early challenge to the $\mathrm{CO}$.

149 Times, 18 January 1905.

${ }^{150}$ Bennett, "Settlers and Politics in Kenya," 275. 
The land committee formation that was a pro-settler team led by Delamere that had been working from its inception until May of 1905. Beginning their work, they called for help. They wanted some government officials in the protectorate, including planters, farmers, lawyers, merchants or whoever present, to give their opinions on all or some of the issues related to land regulations and their actual administration. In reality, their circular was directed only to the chief government officials and the settlers' community and few Indians. No opinions were needed from the Africans. The committee ended up hearing from 44 witnesses who posted written memoranda but the accounts of the witnesses were not included in the report they handed to Stewart. The question that remained pending was how anybody could know if these memoranda were of considerable assistance to the committee or not.

Nevertheless, the committee held four sittings at Mombasa and fourteen in Nairobi. Following is the list of the people interested in the development of the country who were consulted as witnesses:

Table 3.1. Names and Occupations of Witnesses Who Gave Evidence before the Committee

\begin{tabular}{|l|l|l|}
\hline Name & Occupation & Residence \\
\hline V. M. Newland & Land Agent & Nairobi \\
\hline D. O. Roberts & $\begin{array}{l}\text { Licensed Surveyor and } \\
\text { Land Agent }\end{array}$ & “ \\
\hline A. Flemmer & Landholder & “ \\
\hline W. J. King & Manager, Colonial Stores & “ \\
\hline J. Boyes & Farmer & Kiambu \\
\hline W. A. Gain & Builder & Nairobi \\
\hline
\end{tabular}




\begin{tabular}{|c|c|c|}
\hline J. S. Elliott & “ & “ \\
\hline E. S. Grogan & Landholder & -- \\
\hline F. Knowles & Settler & Kamiti \\
\hline F. W. Krieger & “ & Kiambu \\
\hline T. A. Wood & General Agent & Nairobi \\
\hline H. H. Heatley & Settler & Kamiti \\
\hline B. G. Allen & Solicitor & Nairobi \\
\hline N. A. Macgregor & Agent of Dr. Düring & “ \\
\hline A. Linton & Director of Agriculture & “ \\
\hline C. N. M. Harrison & Solicitor & “ \\
\hline A. G. W. Anderson & $\begin{array}{l}\text { Director of B.E.A.T. \& D. } \\
\text { Coy. }\end{array}$ & Mombasa \\
\hline J. R. Wood & Settler & Kiambu \\
\hline J. O. W. Hope & Collector & Dagoretti \\
\hline G. D. Longden & Settler & Nairobi \\
\hline A. S. Frew & Licensed Surveyor & “ \\
\hline W. McC. Wilson & $\begin{array}{l}\text { Secretary, Colonists' } \\
\text { Association }\end{array}$ & “ \\
\hline P. E. Watcham & $\begin{array}{l}\text { Manager, Cotton Syndicate, } \\
\text { Tana }\end{array}$ & Nairobi \\
\hline John Ross & Representing Mr. Ross & Kiu \\
\hline J. Ainsworth, C.M.G. & Sub-Commissioner & Nairobi \\
\hline T. Kendrick & Settler & -- \\
\hline I. A. Grieve & Settler & Mbagathi \\
\hline R. Barton-Wright & $\begin{array}{l}\text { Land Officer and Chief } \\
\text { Surveyor }\end{array}$ & Nairobi \\
\hline A. Ortlepp & Licensed Surveyor & “ \\
\hline Dr. Radford & Medical Officer & “ \\
\hline C. F. Elliott & Conservator of Forests & “ \\
\hline
\end{tabular}




\begin{tabular}{|l|l|l|}
\hline E. L. Waring & Assistant Chief Surveyor & “ \\
\hline A. Marsden & Chief of Customs & “ \\
\hline Premji Ranchodas & Rep. Africa Hindu Union & “ \\
\hline Umedbhoy B. Patel & “ & “ \\
\hline Rowji Visram & Merchant & “ \\
\hline Revashanker Shuckle & Medical Practitioner & “ \\
\hline O. Tonks & Solicitor & Mombasa \\
\hline R. M. Byron & “ & “ \\
\hline C. M. Dalal & $\begin{array}{l}\text { Pleader, Rep. I.T. } \\
\text { Association }\end{array}$ & “ \\
\hline Jaffer Dewji Jamal & Merchant, Rep. “ “ & “ \\
\hline Jewraj Khatao & “ « “ “ & “ \\
\hline Haji Ismail & Merchant & “ \\
\hline W. H. Tanner & Acting Director, P. W. D. & “ \\
\hline Ali bin Salim & Assistant Liwali & “ \\
\hline Source: “Report of and the land Committee,” 25-26. & \\
\hline
\end{tabular}

The table above is incomplete because the authors of the memoranda that were supposedly collected should have been included. Memoranda should have been filed and included in the report. That should not have been a comfortable task, taking into consideration that the majority of the witnesses consulted were predominantly of European descent with favorable opinion of white colonization of the protectorate. E.S. Grogan and A. Flemmer were two notorious settlers whose occupations appeared in the list as landholders. The table showed that being a settler was an occupation that consisted of occupying land. Possessing land was a profession. "Solicitor of Land" was also an occupation. No one was listed as speculator. The African people were not 
consulted by the committee. Ainsworth's name was on the list, which was important.

He had experience and was familiar with African affairs and land issues. He helped the local authorities with the Maasai relocation, which he believed was a matter of expediency and a matter of common sense. To Ainsworth, the Maasai move was a lesser evil than having to witness their extinction, as Eliot suggested. ${ }^{151}$

At the end of 1904 he was asked to give his opinion about the whole issue of land for the land committee. His memorandum survived. Professor Maxom explained how Ainsworth reacted to the whole problem of land, European settlement and African right's to land when he argued that:

Not only was Ainsworth concerned with the Maasai in the Rift Valley during 1904; he continued to give consideration to land and European settlement in Kikuyu territory near Nairobi. By the end of the year, he had concluded that European settlement had practically reached its limits there. In his memo to the Land Committee, he included a strong defense of what had been his policy of the previous two years of creating reserves. He wrote: 'In my opinion it is more than desirable to reserve land for the natives of the country, and if we neglected it we would, in my opinion, be guilty of the most flagrant breach of trust. I am convinced that the safe-guarding of native rights and interests in this connection is practically our first duty when dealing with the land question.' ${ }^{152}$

Ainsworth's memo did not fit into the pro-settlers' land report. The settlers did not want to hear about or mention matters related to Africans' rights to land. Instead they included a range of other issues that were related to their interests. They scripted it in their report, stating that: "In dealing with such a wide question as that of the landlaws of the protectorate-it was inevitable that other matters should be mentioned, which, though not strictly within the scope of the reference, were yet so closely allied to

\footnotetext{
${ }^{151}$ Maxon, John Ainsworth and the Making of Kenya, 148-149. Ainsworth asserted in private correspondence that the Maasai would be forcibly removed from the vicinity of the railway. He was an adherent of the Darwinian concept of the "survival of the fittest;" and he believed that the whites were the fittest and hence, the rightful ones to decide where the Maasai or any other group should be located in the EAP. ${ }^{152}$ Ibid.
} 
the main question that it was impossible for the Committee to pass them over entirely."153 They further added that labor was particularly a question of great importance to tackle. They argued that: "The question of native labour in particular is so closely bound up with the interests of landowners and the development of the country, and many witnesses attached such great importance to it that it was felt that it would be impossible to do justice to the general question without referring at some length to the subsidiary one of labour." 154

It was obvious that labor was going to be a problem that the next commissioner would have to deal with. They foresaw problems and expressed that: "There is no doubt that the future success or failure of the country depends entirely on the methods that will be employed in dealing with native labour. The country must look for its development to the labour of the natives, and if proper steps are not taken with due care and forethought to render the natives contented and their labour easily available, and if the laws dealing with natives are not framed in a wise and liberal spirit and enforced with a firm hand the future prospects of the country may be irretrievably damaged." 155

Labor was an issue worthy of its own committee. Stewart's reference did not recommend specifically that the committee bring the settlers' extra issues, but rather, "to call witnesses and take such evidence as it might consider and add such persons to its member as it sees fit." ${ }^{156}$ No additional member was added into the committee. The CA took total control of the committee from the get go. The clause was understood by the committee as an opportunity to lay the settlers' many grievances in the report.

\footnotetext{
153 "Report of Land Committee," 6.

154 Ibid.

155 Ibid.

${ }^{156}$ Ibid,
} 
The committee was supposed to investigate the working of existing land legislation, as well as to investigate the operations of the Land Office itself. It was supposed to inquire into the Africans' rights to the land and to suggest areas to be sectioned off for African reserves. It was also supposed to investigate the disposition of lands along the coastal strip. In their final report, the committee addressed 87 issues. That meant 81 issues that were not strictly within the scope of the reference.

With Delamere at the helm, however, the final committee report, issued on 25 May 1905, turned out to be nothing more than a document of pure propaganda for the white settlers' cause. In fact, the opinions expressed in the report were almost a verbatim copy of Delamere's expressions two years earlier in his tract, Grant of Land to the Zionist Congress and Land Settlement in British East Africa. ${ }^{157}$ The report suggested that land should be reserved for the Europeans settlers and the Indians. The committee underlined that:

There is, however, no doubt that while in practice it might be possible to exclude Asiatics from the areas reserved for Europeans it would not be possible nor would it be politic to restrain the energies and capital of European planters within limited bounds and not to permit them to be used for the development of the resources of the country outside those bounds.

As a matter of fact there is an enormous area of land eminently suited to the needs of Indian agriculturists outside the area which it is proposed to reserve for European colonization, and it seems therefore detrimental to the best interests of the country to throw open to Asiatic immigration a small area suitable for European colonization whilst there is a far larger area suitable for Asiatics but not for the European colonization still awaiting development. At the present moment

\footnotetext{
.157 When the offer was made in 1902, Delamere reacted strongly against it and cabled London in words nearly identical to his later tract: "Feeling here very strong against introduction alien Jews. Railway frontage fit British colonization 260 miles. Foreign Office proposes give 200 miles best to undesirable aliens. Is it for this the railway was built and large sums spent on country? Flood of people that class sure to lead to trouble with half tamed natives jealous of their rights. Means extra staff to control them. Is the British taxpayer proprietor East Africa, content that beautiful and valuable country be handed to aliens? Have we no colonist for our own race? Country being settled slowly surely by desirable British colonial settlers. Englishmen here appeal public opinion, especially those who know the country, against this arbitrary proceeding and consequent swamping bright future of country." Lord Delamere, Grant of Land to the Zionist Congress (London: Harrison and Sons, 1903) and Ross, Kenya From Within, 66.
} 
a large block of land on the Guasa Ngisho [Uasin Gishu] plateau in an area suitable for European colonization has been offered for settlement to some Jews. The offer was first made in 1902 and since that date nothing has been done to put a term to the option or to insist on the development of the land. The option that was then offered still remains open. If it is possible to put a term to what appears to be an indefinite option it should be done as soon as may be and this block of land which is at present held up may then be thrown open to European colonization..$^{158}$

In regard to any colonization effort, moreover, the report defined the government in terms of being a strict landlord maintaining an almost feudal relationship between itself and the holders of the land by objecting free transfer of their properties. The committee outlined some of its concerns regarding the strict development clauses inserted into leases in the EAP, as well as restrictions on the transfer of leases and the liability of freehold land for forfeiture 117ort h non-occupation. Therefore, the report called for a decidedly more liberal policy to foster the development of land. The committee stated that: "It has been raised as an objection 117ort $\mathrm{h}$ suggestion that transfer should be made easy that a great deal of land will, in a very short time, pass into the hands of Indians. There is of course no objection 117ort $h$ general proposition that Indians should hold land in the Protectorate, but considering that only a comparatively small area of the Protectorate is suitable for European settlement and colonization it is desirable that land within the area should be reserved 117ort he support and maintenance of a white population."159

The pro-settlers' report also denied that there was any danger of speculation. In the opinion of most settlers, already in possession of land, speculation was considered a good thing. It was not 117ort thought of as an unsavory aspect of capitalism, but rather

${ }_{158}$ "Report of Land Committee," 15.

159 Ibid., 7. 
a healthy sign of activity. They acknowledged that: "Speculation and particularly overspeculation is not good for any country, but it should be remembered that the evils that it might cause are far outweighed by the impetus given to genuine business and the attraction held out to capital where the greatest possible security is given to title, and the greatest possible freedom to transfer of interests in land."16o

The committee had little to say with regard 118ort h amendment of land regulations, i.e. rents, limitations on acreage, lease transfers, etc. In other words, the committee had little to complain about. It basically advocated for more of the same, only encouraging legislation that would perpetuate the homestead system through the immigration of more "yeoman farmers" and pastoralists into the EAP, 118ort h further alienate the Africans from whatever patches of land might remain 118ort he. Alienating the Africans meant having separate locations 118ort hem. The report insisted that "there is unanimity of opinion in favour of keeping locations in town district for separate races." 161 That meant separate and not equal 118ort h other races they considered inferior.

In the final section of their report, the committee expressed firmly the European colonists' vision about how they wished 118ort hem economic growth, prosperity and stability in the region. They clearly stated that:

The general future development of the country must be looked for in a combination of capital from abroad and native labour, and it is open to question whether it would be sound policy to encourage the immigration of Indian agriculturists on a large scale. So far as experience has shown, hitherto, the contact with the African native has proved but an indifferent blessing to either race. Should Indian agriculturists, however, desire to try their fortunes in the country there is plenty of land available 118 ort hem, but the Committee think that

160 Ibid.

${ }^{161}$ Ibid., 20. 
the settlement of Indian agriculturalists should be left rather to private and individual enterprise, as in the case with white settlement, than undertaken by the Government. ${ }^{162}$

They finally concluded their report arguing that:

The Committee desire to say the objects which they have had in view in making the foregoing recommendations are on the one hand a desire to see the country opened up as speedily as possible, difficulties removed from the way of settlers, and the future administration of all matters relating to land rendered as simple and as effective as possible, and on the other that the Government, while reaping a due benefit accruing from the development of the land, should be equipped with an efficient system for administrating it in the future in the interest both of the individual settler and the community at large. ${ }^{163}$

The committee made a bold statement with high expectations. They hoped to gain total control of the protectorate. They suggested that an influx of capital, meaning foreign investments, coupled with a reliable and abundant supply of African labor, were the key elements to help jumpstart the economy of the region. In their reasoning, the settlers believed that they were the only group in the protectorate capable of taking initiatives to build a prosperous country, profitable for themselves and the Empire.

The land committee considered the CS's stance about how to run the protectorate as a direct interference insofar as their interests were concerned. They viewed the system of administration as an impediment limiting them with senseless regulations under the FO supervision. The committee's land report also raised an important issue. They stated clearly the urgency of providing cheap labor once reserves were carved for the Africans and land alienated for the settlers' benefits. The committee's foregoing recommendations were indeed an indirect proposal for building a white men's country at the expense of the African labor force. However, the demand for

162 Ibid., 25

163 Ibid. 
cheap labor could be regarded as another starting point for conflict because the question of accessing African labor also was closely allied to the main issue of direct violation of the Africans' rights on the same matter.

The land committee report's indirect petition for cheap labor turned out to be a serious issue in the EAP. Labor troubles later became a matter of struggles between the settlers and the CS. It was under the supervision of the CO that replaced the FO that the problem became manifest. It caught momentum during Sadler's administration but it was first and formally articulated in the pro-settlers' land committee report that Stewart appointed on 31 May 1904. Overall, the committee's report delivered by Delamere, to many extents, was the prelude of the European settlers' posterior demands when they formally articulated them on paper and sent it to London on 23 August 1905. Prior to the settlers' decision to address their grievances to the $\mathrm{CO}$, the commissioner finally sent his remarks on the submitted land report to the CO on 14 August 1905.

Stewart's dispatch was received on 16 September 1905. The commissioner started his remarks by pointing out the remarkable effort and good work that the land committee displayed in inquiring about the protectorate's land question. He formally expressed to the secretary of state that: "With reference to the report drawn up by the Committee I appointed to enquire into the land question in the East Africa Protectorate, I have the honour to submit to you, herewith, my comments. I consider that the report on the whole is carefully thought out and excellently put together, embodying, as it does, the views of the many persons who gave evidence before the Commission."164

\footnotetext{
164 Commissioner to Secretary of State, received at the CO 16 September 1905, Papers Relating to British East Africa, 26-27.
} 
The reality was that the report was carefully crafted by a pro-settler team. The report was about what the settlers considered as vital for the promulgation of their rights and interests in the region. Allowing land speculation, facilitating transfer of land, defining the term of native reserves and recommendations regarding the future administration of the protectorate were main concerns for the settlers. Considering the position of the settlers who felt that the protectorate would be better off if entrusted to them, Stewart provided his opinion on these matters and suggested the following:

There is undoubtedly a strong feeling among the settlers that the conditions under which they lease land in the protectorate are too stringent, and the great complaint is that they have not the right of free transfer. There is much to be said on both sides. Free transfer would bring capital and increase speculation. The first comers, who have perhaps bought land merely as speculation, and have not done work on it, would receive a large profit by selling, and it is doubtful if the purchasers would do any more work than their predecessors. They might simply remain in possession of the land and wait for an opportunity to sell again at a profit. ${ }^{165}$

Stewart's views concurred with the land committee's recommendations on free transfer of land and freedom for speculation. Stewart seemed to have not paid attention to the instructions of the $\mathrm{CO}$ that warned of the danger of alienating large areas of land at the expense of the Africans for the sole purpose of speculation. Allowing speculation was similar to encouraging a struggle for land accumulation between the settlers without the need of having to develop the acquired property.

In that process, land would pass from hand to hand and Stewart considered that "in the meantime, though, money is circulated by this method, the land itself is not developed."166 A market of land speculators dominated by the European settlers was not a sustainable development plan to jumpstart the EAP economy. Speculation was not

165 Ibid., 26.

166 Ibid., 26-27. 
going to repay the large investments of the British Treasury. Speculation was not going to generate or bring goods in the protectorate. Encouraging land speculation was going to expose the protectorate to a new conflict. The danger of possible mass land accumulations for the sole purpose of reselling at profit in a yet unfettered market was real.

Regarding the issue of the transfer of land, Stewart replied that, "Whatever decision is taken with regard to the transfers they ought to be absolutely barred to Indians or natives in the districts suitable to European colonization. There are enormous tracts of land in the Protectorate perfectly suitable for Indians to develop without encroaching on the comparatively small area suitable for European settlement. There is no objection to the small plots and gardens which have already been leased to Indians and natives in the Highlands, as they are generally far from European dwellings, and being of small extent, can be easily controlled."167

This was clearly a scheme to both isolate and alienate the Africans and Indians. The settlers did not wish for any integrative development of the protectorate if they had to surrender even one degree of European hegemony. The preeminent status of Europeans in the protectorate was to extend to all spheres of influence and control. To further this aim, the white settlers insisted on the formation of "native reserves." While Stewart concurred that the establishment of reserves was a good idea, his opinions on the matter of big or small reserves were fluctuating. Said the commissioner: "I have not been able to make up my mind from the evidence at my disposal as to which is the better method- large reserves far removed from centres of European population or small

167 Ibid., 27-28. 
reserves scattered up and down the country. The opinions of settlers differ largely on this point, and whichever scheme is adopted it will require most careful consideration as to the locality, size, etc., of the proposed reserves. The class of native, whether agricultural or pastoral, would also have to be taken into account.”168

Once again, we see some degree of sympathy with the settlers on the part of the commissioner. However, the placing of the Africans on reserves was an idea much in opposition to very concept of establishing a "protectorate," which supposedly should guard all of His Majesty's subjects against alienation through the appropriation of their very hereditary lands. And this is in line with the very core political ideology held among the whites who decided to enter the EAP from South Africa with the objective of turning it into a so-called "white man's country."

But there is a certain point where the interests of King and Empire come first, and the commissioner declared that, "It would be very desirable to allow the ratepayers to elect their members of the Municipal Committee by vote, but a difficulty arises in connection with the coloured vote. As long as the Indians and natives pay taxes, they ought to have a vote for their representative, but the white taxpayers wish to monopolize the right of voting, and I fail to see how this could be countenanced by Government."169 As much as Stewart shared some of the concerns of the white settlers, he realized that his ultimate responsibility was to the Crown. Clearly, he could not allow the whites to exercise a monopoly of the vote at the expense of tax-paying peoples of color. There could not be a future for the protectorate in the Empire if the settlers ended up disenfranchising the Africans and Indians.

168 Ibid., 28.

169 Ibid. 
Of course, the commissioner understood that the Africans' rights were to be respected, if solely to keep the authorities from London and humanitarian groups from coming down hard on them. To this end, Stewart recognized that, "The creation of a post of Commissioner of Native Affairs is a growing necessity, and I entirely concur in the recommendations of the Committee. If this appointment is made, I have an officer in the Protectorate who is fully capable of carrying out the duties." 170

The issue of creating a Commissioner of Native Affairs, like many other concerns in the protectorate, was deferred to others who had been in-country for a longer period of time, enough to garner sufficient experience to render wiser counsel. For example, in going back to the problem of land transfers, Stewart noted that, "A solution to this question may possibly be found in the proposal put forward by Mr. Ainsworth, which is enclosed herewith, namely to levy a tax on all unoccupied or unproductive land whilst allowing free transfer of freehold property." ${ }^{171}$ His common sense prevailed in deferring some of the more controversial matters to his trusted subordinates.

The primary recommendation given by Ainsworth for the development of the protectorate was the lifting of restrictions on land development. He was of the opinion that "all homesteaders should be able to obtain a freehold title to the land they occupy, and should be at liberty to sell out if they so desire." ${ }^{172}$ In other words, a free market would serve diminish rampant land speculation. The restrictions were doing little to augment the economic development of the country, so their elimination would be a big step in the right direction. But the problem remained that any proposal benefiting the

\footnotetext{
170 Ibid.

${ }^{171}$ Ibid., 26

${ }^{172}$ Ibid., 29-30.
} 
settlers would be interpreted by the CA as a step towards their goal of controlling the region for their benefit.

During the same month of August, there was talk among the white settlers of the EAP actually becoming a full-fledged Crown colony. This would entail the establishment of a real Legco complete with elected members. Lord Hindlip, standing for the settlers, argued that: “The greatest grievance among the settlers and the unofficial community, and a most natural one, is that they have no representation, and consequently no voice in the government of the country, or in the formation of regulations relating to matters of vital importance to their interests. Naturally for the present representative government is out of the question, but some kind of Legco in which representatives of the settlers and the unofficial community will have seats is to my mind an absolute necessity." 173 As the colonists quickly came to realize that the officials of the CO may not all be their friends, their leadership put together a set of proposals that was pressed both in Nairobi and London, where Hindlip was dispatched for this very purpose.

The Colonists' Association demands

The actual CA demands to the secretary of state were received on November 13 , 1905. In view of the transfer of the EAP administration from the FO to the CO, the colonists were taking the political lead in advancing their positions in London. Clearly, they saw the transfer as a window of opportunity, hoping that the "paramount factor in Colonial Office rule is to govern according to the wishes of the governed." 174

173 Hindlip, British East Africa, 55

174 Colonists' Association to the Secretary of State, 23 August 1905, received at CO 13 November 1905, Papers Relating to British East Africa, 30. 
The extreme nature of the CA, reflective of the inordinate white South African influence within its ranks, was also manifest in the document. It was made amply apparent that the "wishes of the governed" was only reflective of the political desires of the white settlers and not for any other group(s) resident in the EAP when they wrote: "Our association, known as the Colonists' Association of British East Africa, has been founded to advance the development of this country as a white man's colony, and includes a great part of the white unofficial population in the highlands of East Africa, away from the coast." 175

It was a case of the colored peoples be damned, insofar as the CA was concerned. The leadership of the organization was obsessed with impressing upon the powers-thatbe in London of the "magnificent possibilities offered by British East Africa for white agricultural settlement." ${ }^{176}$ The document containing the association's demands went on to frame this remark with a recitation of the vast tracts of fertile land suitable for farming and grazing that if placed under European management would yield substantial exports that would support a larger white population in the region. The document also drew attention to the previously unforeseen benefits of the Uganda Railway in advancing white settler development throughout the entirety of East Africa.

Despite the potential for prosperity through white settlement, the CA members lamented the lack of progress being made in advancing white settlement in the EAP. Their document notes that "while the stream of settlers has slackened, many good colonists, who had settled, are leaving in despair of making the land pay."177 They wanted the new $\mathrm{CO}$ administration to promote policies that would augment white

175 Ibid.

176 Ibid.

177 Ibid. 
immigration. They believed that this way was the only way to reverse the seeming backward trend that the EAP had been following under the FO administration. The European settlers consistently associated the EAP's struggle for a start of a strong and profitable market economy with the lack of trust vested on them by the local administration. The extreme expatriates within the association firmly believed that turning the protectorate over to them was the only guaranteed path to prosperity and that became their main concern up to 1960.

In addressing the issue of securing better markets, the association members suggested a two-pronged approach. First, they wanted a lowering of transportation costs for their produce. This would entail a joint reduction of railway rates on the Uganda line and steamer freights, which they deemed as cost prohibitive. The other approach involved British East Africa's entrance into the South African Customs Union. But one has to wonder where the loyalties of the CA members lay. Why did many of them leave South Africa in the first place, if it was such a model country and fabulous marketplace? Eliot invited them with the promise of accommodating them. They came and found grounds to complain about the unfavorable existing conditions in the protectorate. The association membership argued that they could not "find sufficient purchasers locally" for their crops, but that the "natural market for the country is South Africa." ${ }^{178}$ It is then plausible to come to the conclusion that the South African political agenda of white hegemony throughout Africa trumped the internal economic expansion of the EAP, at least as far as the white settlers were concerned.

178 Ibid. 
Yet another issue of political significance was the British importation of Indian laws in the governance of the EAP. The document stated that the "East Africa Protectorate is governed as if it were a province of India, and a large number of Indian ordinances are applied to it. Apart from the fact that in some cases the whole and in some, parts, of these Ordinances are inapplicable to East Africa, there is the greatest objection in principle to placing white men under laws intended for a coloured population despotically governed." ${ }^{179}$ The Association document elaborated on those perceived discrepancies that existed between the manners in which whites were treated in India and East Africa, noting that "it is applied with more vigour to East African colonists than to European British subjects in India."180

The association membership also believed that they were unfairly taxed insofar as they were not afforded proper representation through any meaningful establishment of self-governance. The section of the demands titled "Taxation without representation" stated:

Next to the colonists' objections to the laws of the Protectorate, though of equal importance, is their objection to the present method of administration. That method may be described shortly as taxation without representation. Such a principle is, of course, alien to the British constitution, and is tolerated only in newly-organized territories until the number of white colonists justifies the gift of self-government. But between one-man government and self-government the enlightened policy of His Majesty's Colonial Office has provided many intermediate stages. We would respectfully claim, Sir, that the advent of European colonists into East Africa justifies the bestowal upon them of some share in the Administration of their affairs. If the Imperial Exchequer contributes a quarter of a million per annum, the burden of taxation borne by each colonist is far greater per head than that borne on account of East Africa by each Imperial taxpayer. ${ }^{181}$

\footnotetext{
179 Ibid., 31.

180 Ibid.

${ }^{181}$ Ibid, 32.
} 
Therefore, even when it came to questions of taxation, the white settlers were of the opinion that their skin color automatically entitled them to exemptions and special considerations. Also on the economic front, the association members decried the ten percent value added duty and other fees they were required to pay on imports, ${ }^{182}$ as well as the use of the Indian rupee as an EAP currency in lieu of the British pound. ${ }^{183}$ The European settlers were for no taxation without representation and currency regulation for their own economic gains.

One way in which the white settlers might introduce these change was through the facilitation of a transition of the EAP into a British crown colony, provided the changes made in the implementation of it were made with the consent and concurrence of the majority of the white colonists, naturally. 184 The association membership was also concerned about the deployment of black and Indian police ${ }^{185}$ and military throughout the EAP. In the document, the members expressed their desire to supplement this colored force "by raising a so-called Volunteer Reserve, consisting of white colonists, and official employes [sic].”186

Especially insofar as the troop contingents went, the overall fear of the indigenous black population in uniform and armed was clearly stated in the document: "Upon this state of facts, the first suggestion we would throw out is, that in dealing with the aboriginal black races such as those to be met in East Africa, it is much the wiser policy, having regard to results, as well as much the less costly, to use white instead of

\footnotetext{
182 Ibid.

183 Ibid., 35 .

184 Ibid.

185 Their petition stated: "Indeed, the continued use of black police among white colonists, as at present, is fraught with danger, and certain eventually to lead to serious trouble." Ibid., 33.

186 Ibid., 32.
} 
black troops. A small number of high-class, well-paid white troops will yield far better results, and have a much more moral effect, than a large number of blacks." ${ }^{187}$ What the white settlers wanted His Majesty's Government to do in order to carry out such changes in the police and military structure of the EAP was to place effective command under "Burgher Councils," as similarly implemented in South Africa, of course. With this system in place, every white male between sixteen and sixty would be "liable for military service in his own district when called upon."188 The white leadership realized that any coloreds under arms, especially blacks, even police and military, posed a severe threat to white hegemony. If their agenda was going to succeed, gaining control of both the police and military was essential. With regard to possible native uprisings, the document contained this prophetic statement: "The employment of blacks by the Government as soldiers and police to deal with white settlers is absolutely fatal to the maintenance of white prestige among natives, and must seriously hasten the day of black rebellion. We stand practically on the edge of a human volcano, which may at any time burst forth in uncontrollable eruption and destroy us. The day of that eruption no one can foresee, it may be today, it may be tomorrow, or it may be come years hence, but that it will come is an absolute certainty." 189

In addition to this fantastic prediction, the association also demanded that more be done to protect and enhance the mining industry throughout the protectorate, as well as provide non-official Europeans moderate rates for treatment at government hospitals; and as for destitute Europeans, their health care would be free. The association members also complained about the smaller fees for game licenses paid by

187 Ibid.

188 Ibid., 33.

189 Ibid., 34-35. 
government officials. ${ }^{190}$ That was not all; however, they wanted to also limit the freedom of the Africans. Even in the area of semi-autonomous closed districts on some tribal lands, the association demanded a curtailing of black rights. With respect to these "closed districts," the document declares: "We feel, Sir, that it is not in the interest of the Government, nor in that of the settlers, that any districts or provinces should be closed owing to the inability of the Government to give protection to white traders and others. Not only is such an action a sign of weakness and fraught with danger of loss of prestige, but it is also a direct injury to the trade and revenue of the country. In the 'closed districts' at the present time the savage is permitted to follow his own instincts and customs, and to disregard all civilized methods of law and order."191 This was nothing but a disguised land grab. Any perceived "acts of savagery" might be construed as just cause for land appropriation by the white settlers resulting in further land alienation of the blacks.

As clearly indicated in the document, moreover, the colonists believed in the social contract theory, i.e. that government should act upon the "wishes of the governed." The governed, in this case however, referred only to white people. The colonists wanted to impress upon the $\mathrm{CO}$ the importance of developing the EAP as a white man's colony. This, they believed, would ensure a bright future for the protectorate's conversion to a self-supporting crown colony replete with valuable trade and "magnificent possibilities." The colonists felt that the CO was not doing all it could to tap into the full range of options that could make this miracle of progress happen

190 Ibid., 34.

191 Ibid. 
under their watch. To make this happen, the CA came up with above-cited suggestions that can be summarized as follows:

1. Adequate and readily available markets needed to be established. This could be done through the subsidizing of a steamship line and the already existing railway. In addition, inclusion in the South African Customs Union would be helpful.

2. The laws of white settlement should be amended to reflect English common law. Their situation was not analogous to the British presence in India, so any so-called "Indian codes" need not apply to the EAP.

3. Actual English currency was needed to replace the existing Indian currency then circulating throughout the EAP.192

4. Some measure of participation in the actual government of the EAP was required insofar as the colonists paid license fees, rates and court fees. In other words, "No taxation without representation." To that end, the conversion of the protectorate into a crown colony would necessitate the creation of a Legco which at first would be imbued with limited powers of representation, but whose authority would expand over time as more white settlers arrived.

5. The military and police forces needed reorganization. The colonists did not believe that the military or police were providing enough protection for the

\footnotetext{
${ }^{192}$ M. P. Espie, Minute on the Address of the Colonists' Association, 11 November 1905, CO 533/5. Espie analyzes the currency question and determines that objections to the use of the Indian rupee instead of the British pound are based on "certain misconceptions" that can easily be surmounted with economic adjustments.
} 
white population, who were supposedly living in constant fear of extermination by the natives.

6. To develop the mineral wealth of the country, a Department of Mining needed to be created.

7. The officials appointed by the CO should no longer enjoy special privileges over any other whites in the country, i.e. no special attention at hospitals or in the granting of game licenses at the expense of the settler class.

While the motives of the $\mathrm{CO}$ in the EAP sought to be consistent with the noble aspirations of the British imperialists in London, the motives of the CA in the protectorate were solely self-serving. The bold advances by the CA were solely in line with the promotion of their narrow political and economic interests, riding rough over the concerns of the Africans and Asians in the protectorate, only usurping a doctrine of white racial superiority to justify their future brutality and exploitation. It did not matter what these peoples desired for themselves, those in the CA thought that they knew what was best for them. The European settler wanted the Africans and Asians to simply work for them. This is the crux of the dichotomy that existed between the $\mathrm{CO}$ and the CA. Of course, while both parties were in agreement that European civilization and norms should prevail in the EAP, the $\mathrm{CO}$ wanted to protect the rights of all His Majesty's subjects while the CA wanted to squeeze them for all they were worth. That was the reason why the newcomers put their demands on paper for the CO.

The receipt of the $\mathrm{CA}$ demands at the $\mathrm{CO}$ began the process of consideration by the imperial government. Before the $\mathrm{CO}$ was prepared to make any comment or decision, however, they had to wait the views of the leadership of the CS. This process was complicated by the death of Stewart, and thus it was two months later before the CO 
received the assessment of Jackson who acted as commissioner after Stewart's demise. Jackson's dispatch, enclosed comments from other leading administrators in the EAP, such as C. W. Hobley, John Ainsworth, and M. P. Espie.

In his cover letter, of November 11, 1906, Jackson noted: "I have treated several of the questions in very plain language as I wish to urge that the greatest caution be exercised before any radical changes are adopted in the Administration of the country."193 Jackson immediately recognized that some of the demands were reasonable, but most of them were not. This was especially true in light of the fact that most of the settlers had not been resident in the protectorate for any significant amount of time to be qualified in making such demands. ${ }^{194}$ Insofar as the "possibilities" inherent in the economic and political development of the EAP were concerned, Jackson was quick to recognize this reality; but did not agree with the timetable advanced by the association. Jackson stated that, "I believe, now (it is) generally recognized that East Africa is no country for a man to settle in unless he has sufficient money to enable him to tide over the period which he cannot reasonably expect a return on his capital outlay."195 Jackson felt strongly that the majority of white settlers who had arrived so far were having too many difficulties due to the harsh realities they encountered.

Regarding these settlers, Jackson stated "it is such people that form the majority, and are easily led by a few agitators into the belief that the Administration is responsible for their lack of success. It is the country, not the defects in the Administration, that is

\footnotetext{
193 Jackson to Secretary of State for the Colonies, cover letter for Memorandum on the Address of the Colonists' Association, 11 November 1905, CO 533/5.

194 Ibid.

195 Ibid.
} 
responsible." 196 As far as the alleged "lack of progress" being made in the protectorate, Jackson wrote that, "It is now three years since white settlers began to come into this country in any numbers, but with very few expectations they have contributed little or nothing towards its progress, and so far as they are themselves concerned they overlook two very important factors in which most of them are deficient - means and enterprise - and without a small amount of both a man need not settle in East Africa with any hope of success."197 Jackson was puzzled by the Association's incessant demands for opening markets in South Africa while totally neglecting even a mention of the European markets. In addition, railway rates had already been lowered on various commodities also being produced by the colored population. The competition from the Africans and Indians in the markets of maize and potatoes had already resulted in pushing some whites out of these crops insofar as the profit margin was slim. ${ }^{198}$

Of course, "taxation without representation" was a big issue for the association. Their basis for a greater political say in the state of the protectorate's affairs was based on their supposed payment of taxes, thus earning the right to more political participation. However, Jackson dismissed this with the following remark: "I do not consider that we have yet reached the stage at which representative government is necessary or advisable. The white settlers pay no direct taxes of any kind, and it appears unreasonable for them to demand the gift of self-government so long as they contribute so little, and the Imperial Exchequer so much in the form of a grant-in-aid."199

\footnotetext{
196 Ibid.

197 Ibid.

198 Ibid.

199 Ibid.
} 
In this "pay to play" atmosphere, it seems like the CA members did not even possess a hand that they could ante up with. However, Jackson did not totally rule out the idea. Nevertheless, he made clear the terms under which such a legislative body could be constituted:

I am of opinion that a Legislative Council or Advisory Board would be beneficial to the interests of the country. This Council should consist of a few of the senior Government officials, and I would not object to one or at the most two unofficial members being included. I do not, however, consider that it would be wise to allow the settler the right of choosing the non-official members. That privilege should rest with the Secretary of State. I see no reason why gentlemen with large interests at stake who have really done something to benefit and help develop the resources of the protectorate, should not have a voice in the administration of the country. ${ }^{200}$

Being intimately familiar with the protectorate, it is not surprising that with regard to all of the Association demands, but particularly taxation and representation, Hobley was in agreement with Jackson. He wrote

There are probably few countries in the world where the European inhabitants contribute so little to the cost of the administration: no income tax, house tax or land tax is levied, and undoubtedly when the colonists attain greater prosperity one could with equity ask them to submit to slightly heavier taxation.

To turn to the question of representation: while the administration of the Protectorate is so largely dependent on the Treasury grant-in-aid, I consider that the claim of the colonists to participate in the control of the finances is not reasonable, but at this time I see no harm in the formation of a council of advice composed of the senior members of the administration and a few representative members of the unofficial community who would be chosen not by reason of their having the loudest voices but on the basis of having the largest interest at stake. ${ }^{201}$

Hobley also concurred with Jackson that in all probability, the association demands were not at all representative of the views held by the majority of the white settler community. He believed that among this cohort there were certainly a number of

200 Ibid.

${ }^{201}$ C. W. Hobley, Minutes on the Address of the Colonists' Association of British East Africa, 11 November 1905, CO 533/5. 
"hardworking honest men" who did not identify themselves with the South African agitators and who, at the same time, held no sympathy for them. ${ }^{202}$ Hobley wrote concerning the settler community at large, allaying any fears they might have: "The officials of the administration are not antagonistic to the settler community. All they ask is that the settlers will cooperate with them in a liberal spirit and assist them to further the progress of the country by just treatment of the natives and in other ways. European and native interests are not really in opposition. The natives are not in overpowering numbers considering the size of the country, and there is space for both. Moreover, the various tribes have neither common ties nor fanaticism which would induce them to combine against the white men.”203

The minutes of John Ainsworth were also generally reflective of the opinions of both Jackson and Hobley insofar as the association demands. On the point of the formation of a legislative council, Ainsworth added:

The petitioners demand a share in the government of the country- which at present is entirely in the hands of the Commissioner. They profess that they would be satisfied with a Legislative Council in which officials were in the majority provided the minority were chosen with the consent and concurrence of the majority of the white colonists.

This could only be carried out by some system of election, and this I think is to be deprecated.

As Mr. Hobley points out, the claim of the white settlers to representation is not strong from a financial point of view. He estimates that only some 2,500 pounds out of 82,000 pounds raised by taxation is paid by the white colonists.

Nevertheless, and in spite of the additional work and worry caused to the officials of the Protectorate by the introduction of a Constitution it may probably be well to introduce a Legislative Council with unofficial nominated additional members. It should not be too large and probably four officials, two unofficial nominated by the Crown for five years, with the Commissioner or Acting Commissioner will do

202 Ibid.

203 Ibid. 
for a start.204

It is to say that what the officials in the EAP thought and suggested at that time would not stop the settlers from pressing for more political concessions. They wanted a fully recognized participation in the administration of the region.

The reply of the CO to the settlers did not come until much later in the administration of Sadler. It was contained in a dispatch to the commissioner, and clearly indicated that the settlers had run into a dead end insofar as dealing with the $\mathrm{CO}$ was concerned. The secretary of state systematically shredded all of the colonists' suggestions, leaving them with a sunken feeling of desperation. But more on this will be covered in the chapter dealing with the Sadler administration.

\section{$\underline{\text { Conclusion }}$}

The East Africa Protectorate was a purely political construct that for a few moments in time had to deal with a large influx of white settlers, largely from relatively nearby South Africa. These settlers formed the Planters' and Farmers' Association in 1903, that one year later became reorganized as the CA. At first, the membership was largely concerned with the export of maize and potatoes. But under the leadership of Lord Delamere and other racist firebrands, the CA soon became a revolutionary voice for "no taxation without representation," ultimately pressing its list of demands all the way to the secretary of state in London in August of 1905. The Association was trying to take advantage of the administrative transition of the protectorate's control from the FO to the $\mathrm{CO}$, where they hoped to find a more receptive ear. Unfortunately for the colonists, their list of demands was deemed almost laughable in London. The officials in

204 John Ainsworth, Minutes on the Address from the Colonists' Association to the Secretary of State for the Colonies, no date, $\mathrm{CO}$ 533/5. Ainsworth also believed that an executive council should be formed, consisting only of officials. 
London probably wondered how such a small group of settlers could be so audacious as to present a list that not only alienated British subjects of color, but reserved to themselves special privileges solely based on the whiteness of their skin. The boldness of the settlers' demands echoed to such a level that the humanitarian groups in England started to wonder about the question of the need to watch how the EAP was being administrated. It was manifest the European settlers intent to monopolize power in the EAP was an unrealistic move.

The colonists were out of step with the prevailing attitudes of their day; and as a consequence, their days in the EAP were already numbered. Nevertheless, these European settlers that Churchill described as "political animals" would not accept the reality on the terrain. They decided to put up a fight and stand for their rights, in that instance, they undertook frequent agitations. They did not hesitate to harshly criticize or threaten the serving officials, the commissioner or the governor. They went on to even use violence against the local population. These illegitimate and unjustified tactics from the settlers' camp brought a new dilemma worthy of consideration. The EAP needed a stable administration in a healthy political climate in order to focus on tackling the main issue of how to turn the protectorate profitable. However, after Eliot's tenure followed by Stewart's brief term and the mounting demands of the European settlers, the crucial issue was how to again find a strongman, capable of administrating the protectorate effectively under the CO supervision. Appointing the right man for the task could only be done after an objective evaluation of Stewart's short administration of the protectorate. Lessons drawn from his term as commissioner could serve as valid indicator when choosing a new man for a job rendered difficult by the presence of the few turbulent European settlers that Eliot invited in the protectorate. 


\section{Chapter 4}

The age of conflicts and failures in Sadler's administration, 1906-1909: European settlers' violations of the Africans' rights and intense political agitations in the EAP

Introduction

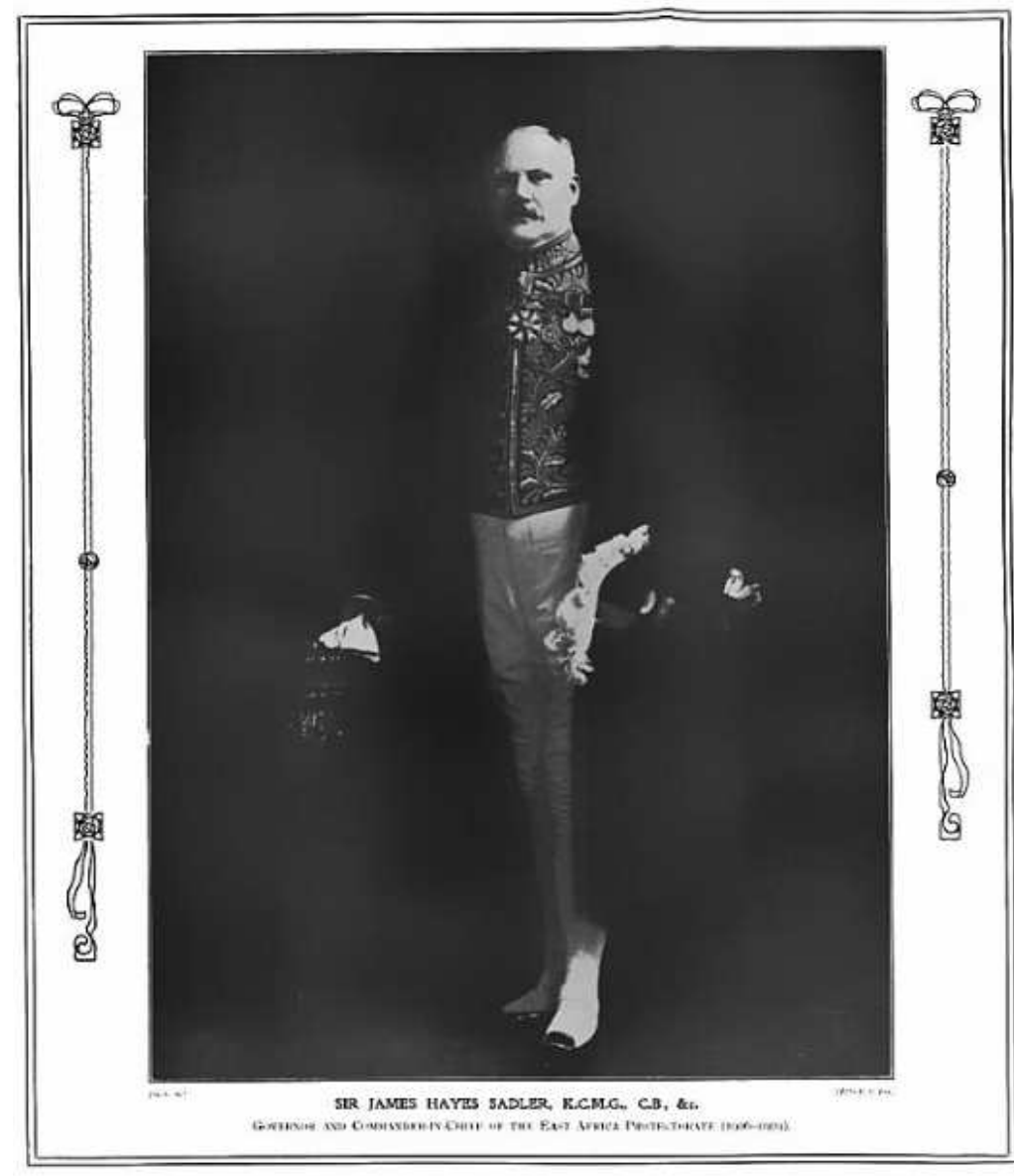

Image 6: Sir James Hayes Sadler. Source: Mungeam, British Rule Kenya, 152.
Sir James Hayes Sadler was

the EAP's third commissioner

and first governor. None of

Sadler's prior assignments

would prepare him for

working with the emerging

white settler group in the

EAP. His inability to work

with the settlers defined his

governorship. As already

noted in earlier chapters, the

expatriates were ever

demanding. Most of them

hailed from the rebellious

South Africa, where respect for indigenous rights was nonexistent. Like the two commissioners that preceded him, Sadler would try to strike a balance between the wishes of the $\mathrm{CO}$ and the interests and the white settlers in the region. That he failed to do so left a significant impact on Kenyan history. 
During this period the ringleaders of the settlers, Grogan and Delamere, brought troubles to the administration of the protectorate. Two major incidents shook Sadler's administration. One was a case of a flagrant violation of the rights of some African workers. The other was an attempt to organize resistance and thereby depose the governor. Grogan staged a flogging of his workers in 1907, and the following year labor troubles reach its peak with Delamere orchestrating a mass action response from the settlers pressuring the governor not to enforce the new labor rules. With the intense political climate prevailing in the region, issues like the implementation of the land bill and labor regulations dragged on. It was an era of continuous agitations and conflicts between the settlers and the administration that kept the $\mathrm{CO}$ as well as the officials in the protectorate at bay. The EAP's reputation of being the most troublesome dependency of the British Empire was well justified. With the actions of the European settlers, the stage was set for the debate about the very essence of impunity and the meaning of crime and punishment in a partisan political context. The European settlers made a resounding political mark in the history of region which traces are still visible in the Kenya of today.

The appointment of Sadler: A familiar face in the EAP

Stewart's brief tenure left numerous unresolved issues for the next commissioner to deal with. While Stewart did manage to secure African reserves for the Maasai, his military forays against the Nandi and Embu, as well as plans for further adventurism in the protectorate and possibly beyond, set off alarms among his political superiors back in London. The bombastic and imperialist image created by these raids was the cause of embarrassment for the Empire. The $\mathrm{CO}$ would have preferred a low-profile 
commissioner, a rubber stamp for their more enlightened and humanitarian policies. This is where Sir James Hayes Sadler came to the fore.

Sadler had a military background, too; but he wasn't a glory hound who made waves in the bureaucracy. He was content to carry out orders as given. Therefore, he was viewed by the powers that be in London as the perfect fit for the next EAP commissioner. With proven field experience in India, Somaliland and Uganda, the CO believed they finally found a man they could trust. From 1901, Sadler provided commendable service to the Crown as commissioner in neighboring, but smaller, landlocked Uganda. Of course, Uganda's climate is more tropical and does not lend itself readily to white settlement. Therefore, this was really more a caretaking position minus the overwhelming political intrigue generated by a white settler class.

Stewart passed away only six weeks prior to Sadler's assumption of command in December 1905. Of interest to note, the EAP provinces of Kisumu and Naivasha had been administrative jurisdictions of Uganda up until their transfer in 1902, and therefore it is not unreasonable to assume that $\mathrm{CO}$ authorities looked favorably upon Sadler's dealings with these provinces and their smooth transition to the EAP under his watch. The CO was cognizant of Sadler's excellent work with Eliot in redefining the western frontier of the EAP with the incorporation of both Kisumu and Naivasha. By the time that Sadler actually assumed command as commissioner of the EAP on 12 December 1905, he already had some detailed knowledge of the operational duties of a commissioner as well as some dealings with internal EAP matters and policies from his close work with Eliot in fixing new borders between the EAP and Uganda. ${ }^{205}$

205 G. H. Mungeam, British Rule in Kenya, 1895-1912 (Oxford: Clarendon Press, 1966), 152. 
British colonial administrators and contemporaries of Sadler perceived him as an older gentleman with charming qualities. ${ }^{206}$ However, this would not be enough in dealing with the many problems engendered by white colonization in the EAP. In his unpublished autobiography, A. C. Hollis wrote that, "Colonel Hayes Sadler differed from both his predecessors. He was, it is true, a soldier such as Sir Donald Stewart; but, whereas the latter had seen much active service, Colonel Hayes Sadler's career had been in the Indian Staff Corps and in the Foreign Department of the Government of India."207 Further elaborating on Sadler, at another point in his autobiography Hollis goes on to remark that, "He was very industrious, kind and hospitable, but weak and vacillating, and quite unable to cope with unruly settlers.”208

As we shall notice as the chapter develops, no love was lost between Sadler and the white settler community. Lady Delamere, taking a cue from her volatile and verbose husband, once referred to Sadler as "Flannelfoot," a name attached to weakness and indecisiveness that would haunt him for the rest of his life. A commissioner needed to be resolute in carrying out the policies of the $\mathrm{CO}$. If he cannot fulfill this role, then he could follow Eliot's course of white settler advocacy. Remaining a fence sitter got a commissioner nowhere. But most of all, it would certainly not garner him respect from any quarter. ${ }^{209}$

The $\mathrm{CO}$, in taking into account the prevailing situation in the protectorate and Sadler's prior experience, had high hopes that he would be the right man for handling all

206 Ibid.

207 A. C. Hollis, a.k.a. Sir Claud Hollis, unpublished autobiography as cited in Mungeam, British Rule in Kenya, 152. 208 Ibid.

${ }^{209}$ Elspeth Huxley, White Man's Country: Lord Delamere and the Making of Kenya, vol. 1 (New York: Macmillan, 1935), 226. 
of the onerous tasks ahead. W. D. Ellis of the CO, a former New College scholar, was greatly influenced by humanitarian concerns and the prevailing liberal sentiments of the age. In his minutes on dispatches from the EAP, he warned the incoming commissioner Sadler about the dubious intentions of white settlers pouring in from South Africa. He did not believe that the white settlers had the best interest of the British Empire at heart in their vocalizations to create a "white man's country" out of the EAP. Rather, he saw these settlers as political opportunists and greedy land grabbers, certainly uncaring for any indigenous rights. In other words, all the talk about a "white man's country" and "civilization" were just talk, a pretext for pushing out the Africans and creating another "Natal" out of the best lands of the EAP. ${ }^{210}$ Ellis' evaluation of the situation was right because Delamere, who until Sadler's arrival was the leader of the settlers, firmly expressed the common aspirations of the CA.

In 1906, Lord Delamere resigned as president of the CA and Frank Watkins took over. That change in the leadership position within the CA did not mean a change of mentality or agenda when it came to the settlers' determination in promoting their interests. Frank Watkins stated that: "In unity and rectitude lies our strength"211 while Delamere, the outgoing president was firm in his belief that the protectorate needed his fellow expatriates for any hope of economic development. Before leaving the CA presidency, Delamere concluded that: "in time it will be found that without the white colonists this country would stagnate and possibly degenerate into a black man's country." ${ }^{212}$ That was quite a statement because the EAP was a black man's country and could only remain as such, regardless the nature of the European expatriates' political

${ }_{210}$ W. D. Ellis, Minute on Jackson to Lyttleton, 18 November 1905, CO 533/5.

${ }^{211}$ William McGregor Ross, Kenya From Within (London: Frank Cass and Company, Limited, 1968), 168.

212 Ibid., 169. 
aspirations. The settlers that Sadler was about to deal with were well organized and knew how to use their influence even in England. ${ }^{213}$ Sadler probably looked at this new assignment as just another line in his resume. He apparently ignored the CO officials' warnings, just expecting to clock in some time and then move on to a plusher position elsewhere in the far-flung empire whence the sun never sets.

If Sadler had paid closer attention to Ellis, he perchance may have avoided many of the obstacles that the white settlers would place in his path. Ellis' also indicated conflicts that existed between the $\mathrm{CO}$ and the FO over EAP white settler policy. ${ }^{214}$ Clearly, Sadler had no idea of the hornet's nest he was about to bump into. Ellis, working in the $\mathrm{CO}$, decried that the office was not doing enough to adopt a policy for the EAP that would secure the rights of Africans and Indians already there. ${ }^{215}$ As far as the white population was concerned, Ellis did not believe that the EAP could sustain more than 3,000, but mostly of the capitalist class. ${ }^{216}$ If Sadler was going to advance any white interests, in Ellis' opinion it should be those of the planters, and not the small settlers. In the CO's EAD, Ellis took note of the consistent record of failure on the part of the small settlers in developing commercially successful enterprises in the EAP. All the small settlers did was whine to various colonial authorities as to their everincreasing demand for government services and cheap labor. Ellis clearly understood

${ }_{213}$ The European settlers used their supporters in London to lobby for their interests. "A liaison group, to safeguard the interest of the settlers and merchants in British East Africa, was formed in London in 1906 as the B.E.A. Association." See Ibid.

${ }^{214}$ E. Brand to W. D. Ellis, 14 May 1906; and W. D. Ellis, Minute on Colonists' Association to CO, 31 October 1906; CO 533/24.

215 Ibid.

${ }^{216}$ Ibid. and H. J. Read, Minute on Jackson to Lyttleton, 18 November 1905, CO 533/5. 
that the EAP could not logically be compared to Australia and New Zealand, these then considered as “white man's countries.” 217

Nevertheless, he turned to them in search of various and appropriate models of policy and legislation for Sadler's consideration. This would definitely lead the protectorate in the wrong direction, insofar as taking workable policies from other parts of the Empire and assuming that they would have equal applicability and efficiency when applied to any other random region under British governance. Clearly, the EAP had its own set of unique problems that needed to be addressed with engaging policies.

If the situation on the ground was relatively tranquil, then Sadler could have probably put together a set of policies with something to satisfy all of the classes concerned by borrowing, as it were, snippets from other crown colonies' policies and legislations that had proven successful. After all, he had done so in Uganda, albeit with a much smaller white presence. In the case of the EAP, however, Sadler would be faced with an entirely different set of problems, particularly in defining new sets of policies appropriate for facilitating a better, overall administration.

In attempting to achieve this, Sadler found that apart from the many military commitments that he inherited from Stewart, it was the domestic affairs of the protectorate that would take up most of his time and tax his administrative abilities to the utmost degree. To address the internal issues, it was necessary for Sadler to work ever more closely with the $\mathrm{CO}$ in the task of formulating new and appropriate policies for the protectorate. ${ }^{218}$ One hindrance that Sadler faced in establishing new policies that

${ }_{217}$ M. P. K. Sorrenson, Origins of Settlement in Kenya (Nairobi: Oxford University Press, 1968), 85. 218 Mungeam, British Rule, 181. 
would find concurrence in the $\mathrm{CO}$ were the incessant and ever increasing demands of the white settlers.

Although the white colonists were small in number, they were the "squeaky wheel" that pushed the CO to shine a bigger than usual spotlight on the affairs of the protectorate. By the time that Sadler had assumed command in the protectorate on 12 December 1905, the official address and demands of the CA had already been forwarded to the $\mathrm{CO}$, along with the attached commentary from various officials of the EAP. ${ }^{219}$ In addition, CO S of S Lyttleton was himself aware of the settlers' demands, having read them in London newspapers in August 1905, one month before receiving the official copy of the CA address as an attachment to the 18 October 1905 correspondence from Jackson. ${ }^{220}$

Of course, Jackson, who took charge in the EAP upon Stewart's death, in his correspondence succeeded in placing the CA demands in their proper perspective. $\mathrm{He}$ noted that the association's declared views, for the most part, were unrepresentative of the majority of white settlers arriving in the EAP, being mostly reflective of the more outspoken South African contingent. In addition, Jackson pointed out that while there were approximately 600 known white settlers in the EAP, the CA counted on a membership of approximately 200. And even of these, there was most likely some dissension in the ranks with regard to the formulation of various demands. ${ }^{221}$

Jackson also believed that it would be totally unfair for the CO to place any inordinate measure of consideration to the association's demands insofar as the Empire

\footnotetext{
219 Ibid.

220 Jackson to Lyttleton, 18 October 1905, with enclosed Address of the Colonists' Association, 23 August 1905, CO 533/4. 221 Ibid.
} 
must forever be cognizant of its vast amount of colored subjects in the formulation of policies, if for nothing else but to be fair. In the EAP he cited the following demographic for 1905: 8,000 to 10,000 Indians and 2,000,000 to perhaps 4,000,000 Africans. How politically expedient would it be to formulate policies that favored maybe 200 recently settled whites, mostly from South Africa, over the interest of millions of other crown subjects? Who would be calling the shots in the EAP, the CO in London or very small cohort of disgruntled settlers?222

To Jackson's reasonable voice were added those of other stalwarts in the EAP, Ainsworth and Hobley.223 All three concurred with Jackson's expressed view that, "To endeavor by legislation or otherwise to make any portion of this country exclusively a white man's country is in our opinion doomed to failure. There is a great future before East Africa, but it is as a mixed race country." ${ }^{224}$ In addition, the EAP administrators also found themselves in agreement concerning white settler political representation, i.e. that it should be limited solely to an advisory capacity or what Hobley referred to as a "Council of Advice."225 Hobley took this position because he felt it was in the Crown's interest to defend the rights of His Majesty's African subjects against certain white settlers to the EAP arriving with less than pure intentions. He described these as nothing more than "adventurers and speculators." 226 Ainsworth even felt that these settlers should be restricted to the lands they already held, not being permitted to

222 Ibid.

223 Jackson to Lyttleton, 11 November 1905 with enclosures C. W. Hobley, minutes on the address from the Colonists' Association to the Secretary of State for the Colonies, 20 October 1905; and Ainsworth, minutes on the address from the Colonists' Association to the Secretary of State, no date, CO 533/5. 224 Ibid. 225 Hobley, Minutes on the address from the Coonists'Association to the Secretary of State for the Colonies, 20 October 1905. CO 533/5. 226 Ibid. 
encroach on other EAP lands which rightly should remain under the control of the administration in order to safeguard them for future development by the African peoples and the peaceful development of the protectorate on its path to one day becoming a crown colony.227 However, no matter what concessions could have been granted to the white settlers, they could always be counted on to continually press more demands for the attainment of political power.

Sadler may not have been fully cognizant of the CO's concerns regarding this matter, but in less than one month since he stepped into office, he became well aware of the CO's concerns regarding the association. Back in London, Ellis heartily supported the recommendations of Jackson, Hobley and Ainsworth. There was no way in Ellis' estimation that the EAP was going to evolve into some kind of white man's country like Australia or New Zealand. If anything, it might eventually emerge as a mixed racial community, something akin to some of His Majesty's Caribbean colonies. And since African people would always be the majority population bloc in the EAP, it would be foolhardy for the crown to allow the protectorate to be ruled by a "handful of white settlers.”228

The small group of white settlers present in the EAP was seeking wealth and power. They were impatient and unhappy with the pace with which the local government and the $\mathrm{CO}$ were handling their primary demand- the implementation of a representative government. The settlers expected Sadler to be sympathetic to their pleas, despite the fact that Sadler had to answer to the CO. They wanted a pro-settler

\footnotetext{
227 Ainsworth, Minutes on the address from the Coonists'Association to the Secretary of State for the Colonies, no date, $\mathrm{CO} 533 / 5$.

${ }_{228}$ Ellis, minute, 9 January 1906, on the address from the Colonists' Association to the Secretary of State for the Colonies, $\mathrm{CO} 533 / 5$.
} 
commissioner reminiscent of Eliot. They wanted a commissioner who would cater to them; although "it had long been established that major policy initiatives, whether involving legislative or administrative action, had to be approved by the S of S. Moreover, the $\mathrm{CO}$ often laid out general policy to be followed and suggested the administrative aims to be accomplished, for example on appointment of a new governor, in the colonies it supervised." 229 Sadler knew that this was the policy and it was his responsibility to implement it. There were two issues of particular importance in the EAP that presented challenges to his administration. These were land issues, specifically the report of the land commission appointed by Stewart in October 1904, and the CO's response to the address of the CA of August 1905.

\section{The Colonial Office, Sadler and the Settlers}

After the appointment of Sadler as the new commissioner in the EAP, the longawaited response of the $\mathrm{CO}$ to the pro-settler land committee commissioned by Stewart was issued from Downing Street on 23 March 1906. The dispatch conveyed the observations of the S of S on the land report and on Stewart's comments about the same topic on 14 August 1905. The S of S, in his initial remarks, pointed out that the whole issue of land in the protectorate had to be re-evaluated. To some extent, he considered some of the land committee's suggestions to be logical. However, Lord Elgin, the new Secretary of State in Campbell-Bannerman's Liberal government was not yet ready to give his full pronouncements on many other issues regarding the potential development of the region. With reference to the report, Elgin formally expressed to Sadler the following:

I recognize the care and ability shown in the compilation of this report and in many points I am in agreement with the conclusions of the Committee. Thus, I fully

\footnotetext{
229 Robert Maxon, Struggle for Kenya (London: Associated University Presses, 1993), 19.
} 
concur in their recommendations that a survey of the Protectorate should be taken in hand without delay; and, as you are aware, a large provision has been made in the Estimates of next year for this service, and some of the surveyors selected for the work will leave this country for East Africa in the course of the present month. There are, however, other questions upon which I am unable, as at present advised, to concur in the proposal of the Committee; and, having regard to the immense importance to the future prosperity of the Protectorate of adopting a right policy in questions related to land, I have decided to take no further action in regard to those proposals pending the report of the officer whom it is proposed to appoint under the title of Commissioner for Land, and whose selection I hope to be able to announce to you at no distant date. ${ }^{230}$

Adding to his first remarks, Elgin stressed the necessity of enlarging the Survey Department's staff and also suggested the appointment of an assistant crown advocate. The $\mathrm{S}$ of $\mathrm{S}$ believed that these changes would lead to the resolution of the delicate question of land ownership in the protectorate.

As much as Elgin understood the many proposals of the committee, he could not allow land to be allocated to the settlers insofar as he felt that they might be more inclined to resell their properties than having to develop them. The settlers wanted all restrictions on the transfer and forfeiture of land to be lifted. They claimed that government interference on freedom of transfer discouraged many capitalists who might otherwise invest in land without worrying about the insecurity of their acquired titles. Nevertheless, the $\mathrm{S}$ of $\mathrm{S}$ had in mind the consequences of a laissez faire policy that would lead to a land rush, inspired by nothing more than speculation and greed. He realized that his ultimate responsibility was to the crown and to all its subjects. On the dangers of speculation, Elgin expressed the following:

I would observe that while I am as anxious as the Committee can be to encourage the settlement and development of the Protectorate by persons either of large or small capital, I consider the evils of unrestricted speculation in land much more

${ }^{230}$ The Secretary of State to the Commissioner, 23 March 1906, Papers Relating to British East Africa, 36. 
serious that the Committee appears to regard them as being. It is not merely the question of the discreditable incidents which characterize the periods of inflated speculation known as "land booms," or the losses to individuals who happen to purchase land at artificially enhanced prices. If this were all, the dangers referred to might be incurred, as the Committee appears to suggest, in view of the advantage of attracting settlers and capital to the country, even by speculative attractions partaking of the nature of a lottery. But the evils of allowing land in a new country to be transferred freely, without any regard to the intention of the transferee to utilize within a reasonable time the resources of the land, are not confined to the period of depression and stagnation which inevitably follows a time of inflated speculation, but have a wider scope. ${ }^{231}$

In backing up his point, Elgin gave a brief history lesson to the land committee. He emphasized the same point that Ellis made, warning that if land tenure was not well supervised by the $\mathrm{CO}$, the office could face the same problems of arbitrary land alienation that occurred in Australia and New Zealand.

Elgin was cognizant of the reversed land policy that plunged Australia into a country of land speculators dominated by influential colonists with unlimited power to purchase large areas of land to divide them into smaller tracts for sale at higher prices. The S of S argued that:

The policy of His Majesty's Government in the first half of the last century was directed towards restricting the alienation of land in Australia by imposing conditions of tenure, such as cultivation of land or maintenance of a certain number of labourers, by putting a comparatively high price ( $£ 1$ an acre) on the sale of lands in fee simple, and by granting leases only for short periods. The policy was, however, strongly opposed by an influential section of the colonists, especially by those who occupied large areas under temporary licenses, which they wished to convert into freehold tenure. These persons fought for what was known in New South Wales as the 'three F's' : Fixed tenure, fixed rents and free sales. ${ }^{232}$

\footnotetext{
${ }^{231}$ Ibid., 37.

232 Ibid. Around 1890 in New South Wales, millions of acres of land had been alienated in freehold, which created a problem of mass accumulation of land in the hands of a few rapacious absentees land owners. That system hindered the development of most rural areas. Considering the history of land alienation in New South Wales, Elgin thought it unwise to facilitate the settlers to hold large areas of land because that could attract speculators from South Africa or elsewhere. In the yet unfettered land market of the EAP, the $\mathrm{CO}$ understood that land regulations were necessary. Elgin's decision to proceed with care until the whole issue of land distribution could be reevaluated postponed the CA's demand for the relaxation of the land law in vigor in the protectorate. As already discussed in chapter II, by article 9 of the 1902 Crown
} 
Elgin realized that if unchecked, the EAP land market could be controlled by the colonists to the disadvantage of the crown. The $\mathrm{CO}$ did not want to take any risk by allowing the settlers of the EAP to indulge in land alienation for speculation. It was from this point that Elgin considered that the land committee should have known better before pushing for the relaxation of the terms under which land could be transferred in the protectorate.

Regarding the settlers' intent to repeat the patterns of land usurpation as it transpired in Australia and New Zealand, the S of S surmised that he was not alone with his views. Elgin reminded the committee to look into the recent past of those colonies. He wrote: "I am not aware whether any members of the Committee have had occasion to acquaint themselves with the history of the land question in Australasian Colonies; but it appears to me that history contains some useful warnings for other countries in a similar position." 233

The second issue of importance was related to the CO's response to the address of the CA of 23 August 1905. After considering this address, on 8 June 1906, Elgin sent his response to Sadler who, in return, had to inform the settlers. ${ }^{234}$ Of the demands presented by the European colonists, the most important of all was the one addressing their political rights in the region and their participation in the administration of the protectorate. But the deepest desire of the European settlers

Lands Ordinance, any unoccupied land after a period of 12 months could be forfeited to the government via the commissioner's power. The settlers were not pleased with that law even though Eliot relaxed it during his tenure. The European settlers simply wanted free holding and free transfer of land in order to prosper in the protectorate. It was similar to asking for a system of high profitability for land speculation, which was always an exit option if cheap labor was not provided to the colonists for the development of their properties. 233 See Sorrenson, Origins, 89.

${ }^{234}$ Secretary of State to the Commissioner, 8 June 1906, Papers Relating to British East Africa, 38. 
was to monopolize the whole political apparatus of the protectorate. Any degree of political representation granted to the settlers would open the gate for yet more demands. They considered the ultimate safeguard of their interests as existing only within the context of the full attainment of political power. On this political matter, Elgin informed Sadler:

The Association proceed in the next place to state their objections to the present system of government, which they describe as one of taxation without representation, and they claim that the advent of European Colonists into East Africa justifies the bestowal upon them of some share in the administration of their own affairs. It does not appear, however, that more than a small proportion of the revenue raised by taxation in the protectorate is contributed by the European Colonists, and for other reasons I do not consider that the time is ripe for the introduction of electoral institutions. But I agree that it is desirable that the Officer Administering the Government should be assisted by a Council in making laws, and I propose to advise His Majesty to issue Letters Patent providing for the establishment of a Legislative Council in which, although the Government would have a majority, there would also be unofficial members appointed by His Majesty, who would be chosen to represent as far as possible the different interests of the community. ${ }^{235}$

But as to the question of representation, there appeared to be some partial condescension in the $\mathrm{CO}$ toward the settlers that the $\mathrm{CA}$ might be able to exploit at some future date. While Read and Antrobus did not agree with most of the settler demands and they did not want to cede power to "a handful of white settlers" to rule over millions of Africans, they nevertheless believed that the crown should come part way in meeting the settlers' position in the establishment of a Legco with a minority of nominated unofficial members. ${ }^{236}$ To the leadership of the CA, this was opening the way for them to get their proverbial "foot in the door."

Since Lyttleton was the retiring Secretary of State, reflecting the views of the Conservative Party platform, he would naturally concur with both Read and Antrobus

235 Ibid.

${ }^{236}$ Minutes by Read, 18 January 1906; and Antrobus, 6 April 1906, CO 533/5. 
that the formation of such a Legco in the EAP was a reasonable one. ${ }^{237}$ Therefore, upon the change of command at the $\mathrm{CO}$, it was Lyttleton's recommendation to Elgin that Sadler be provided with instructions to create such a Legco in the EAP at the soonest possible date. ${ }^{238}$ Inasmuch as the $\mathrm{CO}$ could not budge on any other of the CA demands, it appears as though a faction in the office was willing to provide for some representative outlet for the settlers, hoping that it would be enough to pacify them. Elgin, despite his appointment under the new Liberal Party government, believed it would be permissible to follow the Conservative Lyttleton's recommendation insofar as such a Legco would prove to be powerless and nothing but a token gesture. Therefore, Elgin instructed Sadler to establish the council in the protectorate. ${ }^{239}$ Unfortunately, no one in the CO solicited Sadler's opinions about the council. ${ }^{240}$

This did not mean, however, that Sadler did not have his own ideas about the establishment of a Legco. The local press was full of reports from London, reporting that Churchill had suggested in the House of Commons that a Legco be created in the EAP. Regardless of the CO not asking his opinion on the matter, Sadler took it upon himself to share his thoughts on the subject with Elgin before any decision would be reached so impacting his new role as the EAP commissioner. ${ }^{241}$ While Sadler was not averse to the idea of a council, he suggested that unofficial members be precluded from the exercise of any executive control. And he also maintained that there should be two councils, an executive council formed solely of officials to advise the commissioner on the application and execution of past enactments, especially concerning African affairs,

\footnotetext{
237 Mungeam, British Rule, 181-182.

238 Ibid.

239 Secretary of State to the Commissioner, 8 June 1906, CO 533/5.

240 Mungeam, British Rule, 183.

${ }^{241}$ Sadler to Elgin, 7 May 1906, CO 533/14.
} 
and a Legco to "discuss and advise His Majesty's Commissioner in regard to all ordinances and rules having the force of law, which it is proposed to enact, and if necessary to obtain public opinion thereon." ${ }^{242}$ In the Legco, he advocated for the inclusion of both white settlers and Indians. However, he demonstrated a political weakness when he pointed out his lack of experience in working with bi-racial councils and requested that the $\mathrm{CO}$ provide him with information on the workings of such assemblies in other parts of the Empire. ${ }^{243}$ Said Mungeam of Sadler's letter to Elgin: "Such an expression of ignorance, although no fault of Sadler's, was scarcely a propitious way for the new Commissioner to begin dealings with a Council, and his words almost seemed to foreshadow trouble in the future. By the time Sadler's dispatch reached the Office, Elgin's reply to the Colonists' Address had already been drafted. Sadler's views thus had no bearing on the decision to create a Legislative Council, for the decision had already been taken before his opinions were known."244

The CO did, however, subsequently agree to Sadler's proposal for the establishment in the EAP of an executive council, probably as insurance in preventing any of the CA members from gaining any executive control/authority. The $\mathrm{CO}$ also stated that they did not believe that the protectorate was ready for elevation to the status of a crown colony; but that Sadler's title as commissioner should be upgraded to that of "Governor," by which he was eventually addressed. ${ }^{245}$

The settlers, no matter what they may have thought of the now "Governor" Sadler, were pleasantly surprised at Elgin's decision to create a legislative council in the

\footnotetext{
242 Ibid.

243 Ibid.

244 Mungeam, British Rule, 183.

245 Minutes of: W. D. Ellis, 26 June 1906; H. J. Read, 28 June 1906 and R. L. Antrobus, 3 July 1906; on Sadler to Elgin, 7 May 1906, CO 533/14.
} 
protectorate. ${ }^{246}$ They formally expressed their gratitude to the S of S. From Nairobi on 19 July 1906, the honorary secretary of the CA, W. MacLellan Wilson, sent the following note to Sadler to be forwarded to the Elgin. Wilson wrote: "Sir, I have the honour to request that you would kindly communicate to His Majesty's Principal Secretary of State for the Colonies the gratitude of this Association for the concessions which he has made in answer to the Address sent by this Association on $23^{\text {rd }}$ of August of last year.”247

A relative peace fell over the EAP for the remainder of the year and early into 1907. Elgin's decree appeared to have the predicted calming effect on the white settler class. But before such a deliberative body could be established in the EAP, an unfortunate incident occurred in Nairobi against three Africans, inspired and carried out by white supremacists within the settler community. As it will come to be shown, a deep wedge was driven between Sadler and the settler community as the result of this incident, creating a chasm that Sadler would never be able to breach. Whatever peace there was in the EAP rapidly disintegrated before Sadler's eyes. Radical, eccentric and volatile settlers' leaders like Grogan and Delamere were busy going about and mucking up the waters. These two big men were political agitators who caused so many problems for Sadler.

The politics of violence, the meaning of Grogan's flogging of African servants in the EAP

In 1907 the EAP European settlers were still yearning for sufficient cheap labor and political power. Their sense of superiority and what most of them had witnessed in South Africa regarding the mistreatment of Africans and foreign workers drew them to believe that they could break the law, if necessary, for their interests and without

${ }^{246}$ Sadler to Elgin, 9 July 1906, CO 533/15.

247 CA to the Commissioner, 19 July 1906, Papers Relating to British East Africa, 43. 
consequences. Such was the mentality of most of the settlers that represented the CA, and that was reflected on the political stage of Nairobi, the now capital of the protectorate.

In March 1907, Nairobi residents witnessed the violation of the rights of ordinary Africans at the hands of Grogan. Abuses suffered by workers under the watch of greedy, bad and bold employers were frequent. To the eyes of many expatriates who were supremacists, these inhumane practices were normal and turned into a form of seasonal tradition. In the EAP political agitations and violations of African rights from the settlers' camp often occurred during the month of March. It could be called the EAP "political March madness tradition." It was Ross who asserted that:

Attention has already been called to the fact that many excited actions by European immigrants have taken place in the notoriously touchy months of February, March or early in April. Psychologists might suggest that what is specially wanted for Europeans in Kenya in the trying months is an emotional outlet, such as dancing, theatricals and musical festivals, while for school children an avoidance of examinations and a lightening of school routine should be arranged. In the absence of some active measure of relief, preferably such as may stimulate the artistic sensibilities, it will probably continue to be the case that some slight contributory cause of worry may precipitate unbalanced massaction on the part of European immigrants. ${ }^{248}$

In other words, it might be seen as a type of seasonal affective disorder. As in the history of Rome, when you build an empire, you need to know how and when to entertain the masses to keep the people's attention away from the political and economic realities of the day. If not, frustrations could rise up and burst into an uncontrollable firestorm.

In the EAP incidents like the flogging of African workers or mass protest from the CA challenging the local government happened during the notorious month of

248 Ross, Kenya From Within, 169-170. 
March. Similarly in neighboring South Africa, where most of the settlers came from, such was the prevailing situation. Harsh punishments were inflicted on defenseless subjects of the crown. ${ }^{249}$ The political madness from the expatriates during the month of March became a tradition in the EAP to the point that some high ranking officials noticed it half a century after the opening of the protectorate. S of S Oliver Lyttleton stated in 1954 that: "The political tangle here is baffling. Europeans with the low whisky prices and high altitude pressures, are both irresponsible and hysterical. This is the worst season of the year and even in normal times tempers are at their most brittle in March. One cause of this rather disheartening irresponsibility of Europeans is that there are no Unofficial Members of the Government. Elected European members are thus in a permanent opposition and feel able to pound the government whenever they feel nervous." ${ }_{250}$ The often-reckless behavior of the white settlers was constant during these periods. They were masters of disorder and chaos, always and zealously pressuring the administration.

The colonists' view of Africans and the officials was generally negative. Jackson, the acting commissioner during Sadler's leave, reported to the CO about the tense climate that reigned in the protectorate and the attitude of the European settlers vis a vis the Africans. His dispatch underlined the issue of Africans' rights and the provision of labor for the settlers. Jackson raised the question of human rights, labor provision and morality summarizing all in these terms: "'to deny the native any rights whatever'

\footnotetext{
249 See the debate in the House of Commons. Great Britain, Parliamentary Debates, (Commons), Fourth series, 153, (23 March 1907): 484-488.

${ }^{250}$ Quoted in Robert M. Maxon, Britain and Kenya's Constitutions 1950-196o (Amherst: Cambria Press, 2011), 71.
} 
and that 'the labourer shall be not a labourer but a helot, not a servant but a slave."'251 These were concerns that raised attention among officials in the CO. Jackson's dispatch was in fact a reaction to the abuses suffered by simple African employees at the hands of Grogan.

Captain E. S. Grogan was a familiar face in the EAP. He attained notoriety across the British Empire through his 1898-1899 expedition from the Cape to Cairo. This was the first time that a white man had traveled the total distance overland. But what he saw on the journey left no good impression. He came to the stereotyped conclusion that Africans were steeped in a "primitive savagery" to such a point that they were literally beyond redemption. Unfortunately, his initial experience in Africa would extend to and inform his career decisions and actions in the EAP, whence he arrived in May of 1904 to engage in the running of a timber mill.252 Grogan had to prove himself as a tough settler who would stand for the colonists cause to turn the protectorate administration in their favor. Grogan did not hesitate in challenging the government of the EAP.

On 15 March 1907, the new president of the CA instigated and led the public flogging of three Kikuyu servants in front of the Nairobi Court House. As a prelude to the incident, Grogan's sister and a family friend took a rickshaw out to the Nairobi hospital to visit with Grogan's wife. According to the two women, the three Kikuyu who were employed by Grogan as rickshaw drivers had been drinking heavily. On the way to the hospital, the employees allegedly began to bounce the vehicle on purpose by running it too quickly, thus tossing the passengers from side to side. The women then

${ }^{251}$ Jackson to Colonial Office, 23 March 1907, CO 533/28.

${ }^{252}$ Edward Paice, Lost Lion of Empire (London: Harper-Collins, 2002). Paice provides an extensive biography on the life of Grogan. 
complained to the Africans. However, the Africans did not take too kindly to this, and supposedly pulled the women roughly out of the rickshaw and let them walk the rest of the way home, thus forcing them to abandon their plans of visiting the hospital. ${ }^{253}$

So when they arrived back home in Chiromo in the afternoon, Ewart Grogan asked them why they did not go to the hospital as planned. The women related their account of the Africans' alleged rudeness; and Ewart went into a fit of rage. He grabbed a whip and right away set out to find the Africans. However, by the time the sun had set, he still had no luck in the search. But with the rising of the sun, the Africans had reported to work on time. Grogan tied them up and locked them away while he ate his breakfast and pondered what to do with them, automatically presuming them to be guilty.254 After all, if two white women said they acted rudely towards them, then that must be the absolute truth, Ewart Grogan reasoned.

Rather than take them to a judge for an impartial ruling, Grogan decided that it was time for a little "vigilante" justice to be meted out. So he strolled over to a neighbor's house and informed him that it was his intention to take the young men into the center of Nairobi and publicly flog them. He did not believe that the Nairobi Magistrate would do anything to help him; so he was determined to take matters into his own hands, punish the miscreants and thereby set an example for any other Africans who might decide to step out of their place at some future time. ${ }^{255}$

It was about 9:30 a.m. when Grogan set out with his captives to downtown Nairobi, reaching the front lawn of the Nairobi Court House approximately half an hour

\footnotetext{
253 David M. Anderson, "Sexual Threat and Settler Society: 'Black Perils' in Kenya, c. 1907-30," Journal of Imperial and Commonwealth History 38:1 (2010), 49.

254 Ibid., 50. For the detailed correspondence surrounding the incident see Great Britain, Correspondence Relating to the Flogging on Natives by Certain Europeans at Nairobi, Cd. 3256 (London: HMSO, 1907). 255 Ibid., 50.
} 
later. A curious crowd of about fifty whites gathered around Grogan and the Africans. Of course, the whites in the crowd had immediately assumed the worst, noting that Grogan was carrying a large hippopotamus-hide whip and that the Africans were in his custody and tightly bound. All sorts of imaginings passed through the minds of the white spectators who were anxious to see what Grogan was going to do to the Africans with that whip.

Grogan briefly explained to them what the Africans had done, at least according to his mind, and that he was going to flog them as an example and discouragement to any other Africans who might dare offend any class of whites in the future. Grogan, to his credit, at least informed the crowd that the Africans did not molest the women sexually, but rather insulted them by their refusal to carry on with the task of taking them to the hospital. If he had not clarified this matter, the crowd would probably not have been satisfied until the Africans were lynched. 256

The commotion outside the courthouse attracted the attention of the magistrate himself, E. R. Logan, who came out and tried to dissuade Grogan for going any further. Nevertheless, Grogan was defiant. The whites in the crowd demanded justice and now Grogan felt that he would lose face if he backed down and complied with the magistrate's wishes. Being shouted down, Logan quickly returned to the courthouse, whence a police captain Smith emerged and walked over to Grogan and the assembled mob. Smith forced his way through the crowd and made it through to where Grogan was standing. He placed a hand on the arm with which Grogan was holding the whip, and tried to persuade him that this would not be the way to settle the issue. The crowd

256 Ibid, 
was angry, however, and pushed the police captain away from Grogan and threatened to harm him if he tried to stop Grogan from going through with the whipping of the Kikuyu men. Being so outnumbered, Smith retreated. At this point, the three Africans were lying prostrate and barebacked on the ground. ${ }^{257}$

Grogan, together with two fellow settlers, Bowker and Gray, took turns in punishing the Africans. Each one received twenty-five lashes from the hippopotamushide whip, locally referred to as a "kiboko." Grogan made sure that a Kikuyu translator let the Africans, who also began to gather around this sorry site, understand what the workers were being punished for and that this flogging was to serve as warning to "their people that white men could not stand any impertinence to their women folk in any part of the world." Whether or not Grogan realized just how much global attention this incident would generate, he made his point. 258

Ewart Grogan was milking the incident to gain political advantage. In Nairobi, he was a nominated member of the municipal committee and a visiting justice in the town's jailhouse. He was also one of the largest landowners in the EAP, a big man with a big ego. Just two months previous to this incident, he was elected as the president of the CA. For the time being, the association was merely a self-proclaimed representative organ of the settler class and had no official government recognition. But Grogan had higher ambitions for this group and his political status in the future of the protectorate. From the dais of the association, Grogan took great pleasure in railing against the

\footnotetext{
257 Ibid,

${ }_{258}^{8}$ Ibid, For a more recent account of the Grogan flogging incident see Brett Shadle, "Settlers, Africans, and Inter-Personal Violence in Kenya, ca. 1900-1920s," International Journal of African Historical Studies 45 (2012): 71-72. See Brett L. Shadle, The Souls of White Folk: White Settlers in Kenya, 19oos1920s (Manchester: Manchester University Press, 2015), 130-134.
} 
colonial government and he was going to parlay this incident for all the political gain he could siphon from it. 259

Grogan's challenge to the status quo was a reaction to what he perceived as a sluggish administration that failed to meet the settlers' grievances. According to Paice:

Grogan's single biggest bone of contention with Whitehall was that the Colonial Office had, by the end of 1906, done nothing to address the problems caused by the Foreign Office having pursued a 'policy of drift' in the Protectorate. There were still no signs in Britain of a public and categoric definition of whether the country was to be principally governed with what were perceived as the interests of the African population to the fore, as was the case in neighbouring Uganda; or as a province of India; or as a territory which would continue to encourage settlement by Europeans. This oversight not only caused considerable confusion but triggered a competition for rights between the settlers, the Indians and the African population that was to last for the fifty years of Grogan's active political career and beyond, to Independence. 260

This was the incident that gave impetus to fears of any possible black uprising. A survey of local newspaper columns in the months immediately following this incident gave credence to the high priority that white settlers placed on getting the colonial government to establish a greater degree of law and order in the protectorate. Basically, this meant that the enforcement of the law would be highly subjective. Africans would, therefore, suffer because of the law's inordinate application and enforcement. There were three settler concerns with respect to the issue of law and order: the elimination of Indian jurisdiction, greater white control of the constabulary and increased settler political representation through constitutional changes. All of these concerns focused on the eventual transformation of the EAP into a "white man's colony." These are the issues, of course, that Grogan, as the CA president, was most vocal about.

259 Anderson, "Sexual Threat," 50-51.

260 Paice, Lost Lion of Empire, 201. 
As more women came to join their husbands as white settlers in the EAP, the majority of the association membership, at least, was in agreement with Grogan that the enactment of these policies would strengthen law and order throughout the protectorate and provide their women folk with a greater sense of security. Seeing that they brought their wives and daughters to this new land literally surrounded by millions of Africans, they most likely reasoned that while it was probably the very least they could do, it was a sufficient start. With regard to Indian jurisdiction, the crown determined that the EAP was subject to the Indian penal codes as administered by the Court of Appeals from Zanzibar. The settlers argued that this was inappropriate insofar as having any Indians or Indian laws holding sway over any "white man's country," such as they perceived East Africa to be. ${ }^{261}$ In April 1906, the CO had, in Shadle's words, "extended to whites in East Africa the right to trial by juries of their peers-their only peers being other non-official white men."262

The issue of greater white participation in the constabulary also harkened to the maintenance of European superiority in the protectorate. If more whites were serving in the constabulary, they could keep a more watchful eye on the activities of the African policemen, or "native Askaris," making sure that they were not even detaining any Europeans, let alone arresting them, on any charges. And lastly, there was the matter of increased white settler political representation. Of course, at the recommendation of the CO, Sadler was authorized to grant this to the settlers to a limited degree. The construct and nature of this legislative council would become a hot topic at the 23 January 1907 meeting of the CA, the same meeting where Grogan was elected president.

${ }^{261}$ Anderson, "Sexual Threat," 51.
${ }^{262}$ Shadle, "Settlers, Africans," 78. 
Now Grogan felt he could push the envelope, so to speak, and force the hand of Sadler, and the $\mathrm{CO}$, in granting the fullest political accommodations. Clearly, the issues of law and order in the EAP were contextualized in the concept of white racial superiority. ${ }^{263}$ Since the majority of these settlers hailed from South Africa, where a relatively small white settler community maintained a strong racial code of punishment, it is not surprising that the CA would press for the enactment of similar laws and practices.

Clearly floggings and corporal punishments in general had racial character as indicator in the EAP and the entire British Empire. News reports of the flogging of Africans or workers imported from Asia were commonplace in South Africa. The Advertiser (Adelaide, SA: 1889-1931) reported on many of these occurrences. In one edition, it stated that,

..... heated debate took place in the Commons yesterday on the motion of Mr. V.P. Byles, liberal member of North Salford, disapproving of the action of Lord Milner, when High Commissioner of South Africa and governor of the Transvaal, in authorizing the flogging of Chinese miners, and on the amendment moved by Mr. Winston Churchill, the Colonial Under Secretary, condemning in general terms the flogging of Chinese as a breach of the law. The amendment invited the House, in the interests of peace and conciliation in South Africa, to refrain from censuring individuals. Mr. Byles, in submitting his motion, contended that if Lord Milner's action was condoned 'every prancing pro-consul would be encouraged to play the little autocrat.' Mr. J. Chamberlain, amid much interruption, brilliantly and passionately defended Lord Milner. He seathingly denounced what he called the "persecution of a great public servant possessor of a splendid record for a single error of judgment'. Lord Milner's opponents were vindictively trying to humiliate him, while they were afraid to impeach him. Mr. Chamberlain explained that the suggestion for the infliction of corporal punishment had come from Mr. Evans, the protector of Chinese in the Transvaal. In that suggestion Lord Milner had verbally acquiesced. In conclusion, Mr. Chamberlain characterised Mr. Churchill's amendment as 'cowardly and contemptible, being framed to catch votes by attacking without naming Lord Milner.' Mr. Winston Churchill stated that it was clear that Lord Milner had been guilty of a grave dereliction of public duty in sanctioning illegal flogging. While

${ }^{263}$ Shadle, The Souls of White Folk, 134. 
admiring the moderation of Mr. Byles' motion the Under Secretary of the Colonies the practical utility of formally censoring a man who had 'served the Empire strenuously, faithfully, and disinterestedly, and who is now merely a retired Civil servant without a pension or even gratuity'. Besides it was contrary to usage to censure a man unheard. Was it worth the while of a strong party to pursue him further? If the motion was passed it would aggravate the social and racial animosities prevalent in South Africa. ${ }^{264}$

From this account, it is clear that news of what was happening in South Africa was not being contained there. On London's part, efforts to monitor and constrain the imposition of corporal punishments in the colonies arose out of the parliamentary debates that swirled around prison reform in the British Isles throughout the 1890 . Joseph Chamberlain, S of S from 1895 to 1903, was particularly concerned about the political repercussions that might arise from the excessive use of corporal punishments both at home and abroad in the colonies and protectorates. Chamberlain held the opinion that should punishments have to be imposed, the treatment of offenders overseas should not deviate too far from those practices that prevailed on the home turf. 265

Of particular concern to the colonial secretary were the reports of extreme punishments emanating from South Africa. Chamberlain was particularly drawn to a flurry of cases from the Natal Province that had reached his desk in London. In these cases, it was apparent that corporal punishment was being more freely resorted to than in the United Kingdom. Chamberlain was clearly disheartened by this. He commented that, "there has been in some instances perhaps a tendency rather to widen than to

\footnotetext{
264 Advertiser, Adelaide, South Africa, 23 March 1906.

265 David M. Anderson, "Punishment, Race and 'The Raw Native:' Settler Society and Kenya's Flogging Scandals, 1895-1930," Journal of Southern African Studies 37:3 (2011): 481.
} 
contract the scope of its application.... There is apt to grow up a perverted public opinion satisfied with keeping order by the lash.”266

The political repercussions Chamberlain had in mind transcended other aspects of the flogging and larger issue of corporal punishment. For while such corporal methods may have seemed both effective and inexpensive, other issues rose to prominence when the "offenders are for the most part of a different race and colour from those who are placed in a position to control and to punish them," and also where, "there were not the 'checks and safeguards' against abuses which exist in more highly developed countries.”267

In other words, the issue of race was the elephant in the room that very few were willing to recognize; so Chamberlain has to be credited with at least having the fortitude to come out and frankly admit it. Chamberlain hesitated to use the race card as a pretext for giving license to "men of rough fiber" 268 in administering the laws of the empire in her far-flung possessions and territories. After all, perception is just as important a factor as reality itself. A flogging may serve to restore a modicum of discipline and order in a colony, but the long range effects spanning a global empire could prove disastrous.

Chamberlain would have to address the issue of flogging again in 1902, after he reissued his 1897 directive, but offered draft legislation that reduced the number of strokes that could be awarded under any sentence of flogging. In the intervening years since his 1897 directive, the colonial secretary was unable to restrict the frequency of the punishment. His new strategy was therefore going to be one of reducing its severity. 
His new and so-called "Flogging Regulation Ordinance" reset the number of strokes that could be applied to 24 as the maximum punishment to be inflicted for either single or combined offenses. No prisoner could receive more than 24 strokes of the lash. And the only one having the authority to implement this punishment would be the colonial governor, with females being exempt from all forms of capital punishment

whatsoever. ${ }^{269}$

David M. Anderson notes that:

By the time this Ordinance was applied to Kenya (then the EAP), there were already other laws in place permitting corporal punishments. The Indian Penal Code, which was applied in East Africa from 1897, contained wide-reaching provisions for corporal punishments. The power of corporal punishment was originally given to the courts under the Native Courts Regulations of 1897, section 72. The terms of this legislation now seem chillingly severe: floggings of 40 lashes and more were not uncommon, and multiple punishments might be allotted to a single prisoner. In the Chief Native Court, punishments up to 100 lashes were sanctioned. Without a proper prison system in place, 'the kiboko (a whip made of hippopotamus hide) was regarded as the ordinary corrective measure to be generally applied in all cases where the delinquent was a native. 270

Overall in the EAP, however, social and racial animosities existed only due to the presence of the European colonists who came from South Africa. The concern of the CO was to avoid the violation of the Africans' rights in the protectorate. Nevertheless when there were violations like in the case of Grogan's flogging of his servants, no effective sanctions were taken, at least in a timely manner. The reality concerning the violations against Africans was downplayed in the EAP. The High Court had become so concerned with floggings that "were still at times unnecessarily awarded" in the EAP that by 1912

269 Ibid.

${ }^{270}$ Ibid. Quote on kiboko derived from Chief Justice Hamilton to Chief Secretary, 27 December 1912. 
Chief Justice Hamilton issued a strongly worded circular to all magistrates on the subject and corporal punishment in general, severely limiting its application. ${ }^{271}$

Nevertheless the South African's tradition of flogging workers was common in the EAP. In the same year as the Grogan incident, "one in every 400 African adult males in Natal (a province in South Africa) was subject to a judicial flogging- a figure that takes no account of the extra-judicial punishments administered to labourers on the farm without resort to the courts." ${ }^{272}$ As in South Africa, so it was in the EAP. Here the settlers strove to forge a community identity through the generation of a self-image of being true "frontiersmen," the vanguard of European civilization in Africa, the heart of darkness. The settler farmers augmented this perception insofar as they saw themselves as paternalistic plutocrats, lords and masters of their manors, estates and the Africans who worked them and over whom they presided. 273

The expatriates held the final say in the disposition of any African that had the misfortune of being tied to their land, or so they thought, and not any colonial government fraught with liberal frailties. Of the $\mathrm{CO}$, the settlers, through their association, decried it as being distant, parsimonious and unimaginative. They saw the bureaucrats in London as being more concerned with the rights of Africans than those of white British subjects. The settlers saw themselves as the builders of the country, and thus reserved the right to dictate policies to the Africans to themselves, and not the Crown. David M. Anderson best summed it up when he wrote that, "The right of the

${ }^{271}$ Ibid.

${ }^{272}$ Ibid., 480.

273 Shadle, The Souls of White Folk, 44-45. 
settler to discipline his African labour in Kenya, as in Natal, came to be viewed as the cornerstone of the political independence of the colony itself." 274

By all rights, the British officials had the authority to deport Grogan and his two partners in crime. Churchill, who was in the EAP during October 1907, heartily endorsed the EAP in taking deportation measures against the offenders. ${ }^{275}$ Churchill penned a famous memorandum concerning this incident: "We must not let these first few ruffians steal our beautiful and promising protectorate away from us, after all we have spent upon it- under some shabby pretense of being a 'responsibly governed colony.' This House of Commons will never allow us to abdicate our duties towards the natives- as peaceful, industrious, law abiding folk as can be found anywhere.”276 However, Grogan and his pals got off with but a reprimand and slap on their wrists. Potential deportation hearings were consistently delayed and eventually lost in the bureaucratic shuffle of the EAP courts due to inside influence by the CA members in high places. Additionally, the $\mathrm{CO}$ was most likely sick and tired of both hearing about and dealing with this nasty business. 277

In exercising this right to discipline African labor, Grogan touched off a political issue with both immediate and far-reaching implications. The CO provided an immediate impact of the flogging as officials there learned of the incident from press reports. Elgin authorized an immediate telegram to Jackson, acting as commissioner while Sadler was on leave in Britain, requesting further details. ${ }^{278}$ Jackson quickly responded with a number of telegrams and dispatches. He assured the $\mathrm{CO}$ that he was

\footnotetext{
274 Ibid.

275 Ronald Hyam, Churchill and Elgin at the Colonial Office: 1905-1908 (London: Macmillan, 1968), 411. 276 Winston Churchill, Minute, 27 June 1907, CO 533/28.

277 Hyam, Churchill and Elgin, 411.

${ }_{278}$ Elgin to Jackson, telegram, 15 March 1907, CO 533/28.
} 
on top of the situation and that the CS was taking measures to prevent any group of Europeans from further taking the law into their hands and checking a potential African uprising. He dismissed the latter, which was an immediate concern of the $\mathrm{CO}$ was that it would bring about a severe and violent reaction from the African population, as pure speculation as there was "absolutely no foundation" for reports of an African uprising in the making. He assured the $\mathrm{CO}$ that most settlers in the EAP were not concerned about a possible black racial uprising. He described the measures he took as precautions, including a proposal to set up a defense committee and provide arms to Europeans who felt threatened. Jackson pointed out, however, that only one settler came forward expressing a desire for assistance, but he only required ammunition as he had enough armament at his farm. ${ }^{279}$ The incident shook the EAP and produced negative reverberations in Britain where condemnation arose in the press, public and parliament as well as in the empire. Jackson provided details of the incident in a dispatch on 25 March with which he forwarded Hobley's observations as well. Jackson reported that his investigation of the incident showed it was the work of a few hot heads whose motivation was political. Grogan and the others wanted to make an example of the Africans, hoping that it would serve as an affront to the EAP administration and augment Grogan's growing popularity among the settler class. Jackson also noted that, in his opinion, the alleged infractions of the Africans of bumping and shaking the rickshaw so as to offend the two white ladies, were not as serious as Grogan and the others made them out to be. He decried Gorgan's taking the law into his own hands in

\footnotetext{
279 Jackson to Elgin, telegram, 16 March 1907, CO 533/28. Later the CO published portions of the correspondence relating to the Grogan flogging incident, but confidential despatches were ommitted. Great Britain, Correspondence Relating to the Flogging of Natives by Certain Europeans in Nairobi, Cmd. 3562 (London: HMSO, 1907).
} 
response to the young men's allegedly inappropriate actions. The acting commissioner further maintained that the irresponsible reporting of some of the Nairobi newspapers

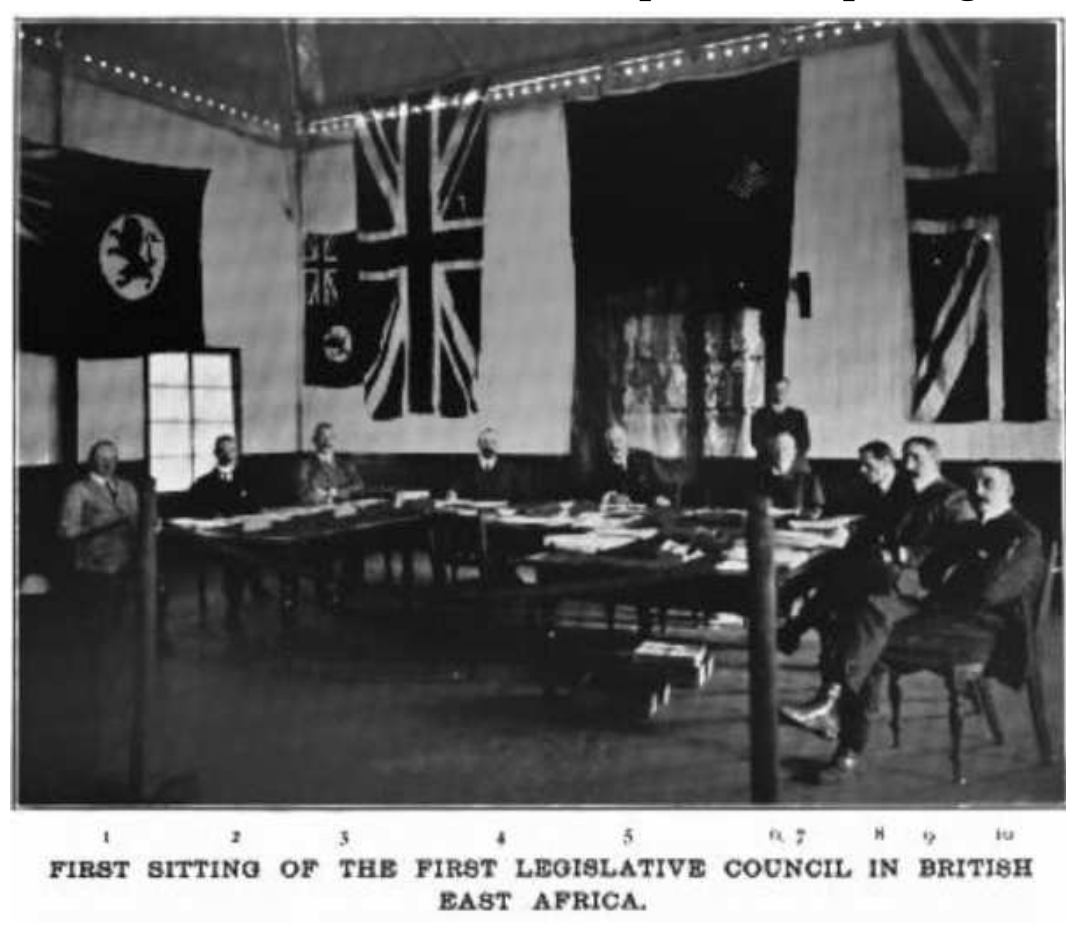

Image 7: First Sitting of the First Legislative Council in British East Africa. Source: Gale, East Africa (British), 27. was an important factor in stirring up the settlers. Both he and Hobley raised the question of whether the planned establishment of a legislative council should go ahead in light of the actions of the head of the CA. ${ }^{280}$

\section{Grogan's actions} eventually led to his arrest along with his two companions on a charge of

unlawful assembly. Jackson reported in April that at the trial Grogan, as the ringleader, was convicted and sentenced to one month in prison, which was served under house arrest, and a fine of 500 rupees. The other two defendants received significantly lesser sentences. ${ }^{281}$ The issue of whether or not to establish a Legco as planned was worked out between the $\mathrm{CO}$ and the CS. ${ }^{282}$ Grogan's action had its impact. It resonated loudly within the settler community in the region and their supporters in Britain.

\footnotetext{
280 Jackson to Elgin, 25 March 1907 with enclosure Hobley to Jackson, 22 March 1907, and Jackson to Elgin, confidential, 27 March 1907, enclosure of Ainsworth to Jackson, 18 March 1907, CO 533/28. ${ }^{281}$ Jackson to Elgin, 9 April 1907, $\mathrm{CO} 533 / 28$.

282 Elgin to Jackson, telegram, 9 April 1907, CO 533/28.
} 


\section{Significance of the Grogan's incident}

The significance of the Grogan incident, despite being dismissed by Jackson, was important for four reasons. First Settlers in the region and advocates of unregulated British expansion in Britain saw Grogan's action as a good example to follow. Grogan was praised for his actions, while some authorities in London and in the protectorate rebuked them. Paice argued the following:

What did divide the public opinion was the question of whether Grogan's defiance of the Empire's authority was excusable. There is no doubt that this skirmish was won by Grogan's adherents throughout the Empire, and marked a significant watershed in the relationship between colonists everywhere and their detractors. Headlines in the Protectorate's Star, Times and East African Standard proclaimed 'Grogan Shows The Way', and letters of support poured in to colonial and domestic newspapers. 'If ever there were a sane and heroic mind in a brave's man body it is Grogan's' read one; 'one of those who have made our Empire what it is - not by diplomacy, but by forceful strength of character' read another. Ethel Cockburn, the matron of Lady Dudley Nursing Home where Grogan had recuperated after his operation in 1903, wrote 'I hope you suffered no ill effects from the gaol, we are all so proud of you here [in South Africa]. Lord Hindlip campaigned vigorously on Grogan's behalf in the Lords, as Sir Charles Eliot in Whitehall. The pressure was less on Grogan than on the British government's management, or mismanagement, of it colonies. ${ }^{283}$

The colonists and their supporters seemed to have made their mark in the region, all thanks to Grogan's daring action. The colonists emerged as winners here while "the incident attracted some attention in the House of Commons, the government eventually producing a parliamentary paper from dispatches outlining the events; these undermined the wide claims for self-rule the colonists were making and "again alerted a few sections of British opinion conditions in the protectorate." 284

\footnotetext{
283 Paice, Lost Lion, 221-222.

284 Anthony Clayton and David C. Savage, Government and Labour in Kenya 1895-1963 (London: Frank Cass, 1974), 33.
} 
Secondly, it caused the convening of the new Legco to be temporarily postponed at the behest of both the EAP government and the CO.285 It would not be until August 1907 that the council would hold its first meeting, and this only at the behest of Elgin who by then assumed that enough time had elapsed to let the Grogan incident just blow over.

Thirdly, but just to be on the safe side and hoping that more reasonable minds would prevail, the $\mathrm{CO}$ stipulated that Grogan was not to be nominated to this new council, even though he had served as the CA president. ${ }^{286}$ And finally, the incident cast a huge shadow in both the protectorate government and the $\mathrm{CO}$ regarding the future prospects of white settlement in East Africa. Jackson noted in a confidential dispatch that the incident could best be understood in the context of the work of a small band of settlers, largely South Africans, who should have never been allowed to settle in the protectorate. He viewed them as professional agitators whose express purpose was, "to deny the native any rights whatsoever and to strip him of his land and cattle.”287

Jackson further explained that in all probability the Grogan incident was but a pretext that allowed this insidious group of rabble-rousers to stir up a black uprising that they could exploit through acts of cruelty and oppression, to seize the opportunity for confiscating the Africans' possessions. ${ }^{288}$ Before the power of the extant association leadership grew any more in the EAP, Jackson believed that the EAP and the CO needed to come together and develop a definite and workable African policy that would serve to protect African rights. Along with his dispatch, Jackson enclosed a letter from

\footnotetext{
285 Jackson to Elgin, 25 March 1907; with enclosure of Hobley to Jackson, 22 March 1907; Elgin and Ellis Minutes, undated; and Elgin to Jackson, Telegram, 23 April 1907, CO 533/28.

286 Antrobus, Minute, undated, on Jackson to Elgin, 25 March 1907, CO 533/28.

287 Jackson to Elgin, confidential, 27 March 1907, CO 533/28.

288 Ibid.
} 
Ainsworth in support of the formulation of just such a policy.289 In this letter, Ainsworth highlighted the duty of a protectorate to safeguard all of His Majesty's subjects that reside within its borders. This would include the maintenance of their personal security as well as their rights. Noted Ainsworth:

The EAP contains approximately three million native inhabitants, and about fifteen hundred non-official whites. Yet with all of this, in so far as I am aware, no definite native policy has been laid down, while the whites maintain in and out of the press that it is a white man's country. That white men have come here to stay we must accept as fact. This being the case, it should, in my opinion, be the duty of the Government to lay down in a definite manner, so that there can be no misunderstanding on the subject, exactly what the native policy is to be. ${ }^{290}$

Churchill, now Parliamentary Under-Secretary of State, was also in agreement with Jackson and Ainsworth. Describing the South African cadre at the core of the association as nothing more than "a few ruffians," he regretted that the day might arrive when these men would walk off with the colony under the pretext that they were going to more responsibly govern it than either the EAP administration or the $\mathrm{CO}$ had been able to do. Churchill commented that, "The House of Commons will never allow us to abdicate our duties towards the natives- as peaceful, industrious, law-abiding folk as can be found anywhere."291

Elgin was in general agreement with the sentiments expressed by Jackson, Ainsworth and Churchill. However, he felt that British policy would be judged by the practical application of measures taken to protect the Africans and their rights rather than by the mere exposition of platitudes and abstract principles. To make this happen, Elgin was determined to keep shuffling the administrators around in the EAP until a

\footnotetext{
${ }^{289}$ Ibid, with enclosure, Ainsworth to Jackson, 18 March 1907, 533/28.

290 Ibid.

${ }^{291}$ Churchill, minute of 24 May 1907, on Jackson to Elgin, confidential dispatch, 27 March 1907, CO $533 / 28$.
} 
suitable team could be assembled. ${ }^{292} \mathrm{~S}$ of $\mathrm{S}$ Elgin was also of the opinion that the preservation and maintenance of African rights should be paramount in the protectorate. In regard to Grogan and those of his ilk, Elgin understood that the continued expansion of more rabid settler power would not serve the interests of, "the natives (constituting as they do an immense majority of the population), but also of the innocent white inhabitants; I am determined to restrain and punish those who commit such acts." 293

It was clear, however, that Ewart Grogan had sympathizers. Many settlers, feeling so outnumbered, began to view the local black population in terms of a peril to their continued existence in the EAP. Sadler's weakness in the face of such opposition to the EAP government and the $\mathrm{CO}$ only further emboldened the white settler class. In fact, after the flogging incident, it was the other radical leader, Delamere, who was now in the driver's seat at the CA. The international heat generated by the incident could only bring the wrath of the whole British Empire crashing down on the association. So despite the preference by the South Africans in the association for Grogan, they prudently opted to reinstall Delamere, who had served as their leader from 1905 to 1907, the term before Grogan's. ${ }^{294}$ In other words, the changes in the association were merely cosmetic in nature. As the adage goes, "You can put lipstick on a pig, but it's still a pig."

At about this time in the EAP, the young Churchill's observation was revealing. He noted in his account of his 1907 visit that "Every white man in Nairobi is a politician;

\footnotetext{
292 Mungeam, British Rule, 186-187.

293 Hyam, Churchill and Elgin, 411-412.

294 George Bennett, "Settlers and Politics in Kenya, Up to 1945," in History of East Africa, vol. 2 Vincent Harlow, et. al., eds. (Oxford: Oxford Clarendon Press, 1965), 283.
} 
and most of them are leaders of parties." 295 On the internal politics of the EAP, Churchill sided more with the aims of the Pastoralists' Association than that of the CA. The Pastoralists were opposed to the Colonists' practice of applying for extra land allocations in the names of their dependents and also of the undue influence gained by the CA in the newly formed Legco. The Pastoralists were largely centered in the highlands where they first organized themselves into an association at Nakuru. The Pastoralists were under the leadership of Robert Chamberlain, who from his arrival in the EAP, spoke out vigorously against Lord Delamere with his vast landholdings and undue political leverage. ${ }^{296}$

Chamberlain thus offered a moderating alternative. Should the settlers follow Chamberlain's lead, they might secure an improved standing with colonial officials. But following the incident, it was apparent that the settlers were divided. What future would they have in the EAP without an effective spokesman to clearly articulate their demands from a unified political base? Could they rely on Delamere, whom they largely distrusted because of his elitist heritage, or should they place their bets on Chamberlain and his London-favored Pastoralist wing? Getting right down to it, the majority of settlers, mostly of South African origin, would have preferred that the flamboyant and rabble-rousing Grogan remained as their leader.

Nevertheless, his involvement in the racist incident would certainly block any efforts at reinstatement, at least in the immediate aftermath. After the incident, Grogan left protectorate and went to England with his wife who was sick. He went on to try to do politics in England but did not succeed. Grogan later returned to the region in 1910.

295 Winston S. Churchill, My African Journey (London: The Holland Association Press, 1962), 21. 296 Ibid. 
The EAP was the only political arena where he could make noise. Once back in the protectorate, he would again lead the settlers in their quest for political recognition and power. Nevertheless, in Grogan's absence, the colonists still remained active. In the EAP, if Grogan was not leading the settlers, Delamere carried the task.

Delamere and the Colonists' Association claim for cheap labor

After Grogan's flogging of his workers, a year later in 1908, Delamere and the settlers challenged the governor not to introduce new labor rules that they considered detrimental to their interests. The colonists turned the table on Sadler. Jackson, the Deputy Commissioner for Eliot's administration, once noted that the EAP was turning into a "country of nigger and game-shooters" and that Delamere was the ringleader among them. ${ }^{297}$ Jackson further added that he and Delamere were as "thick as thieves" and did what they could, along with Eliot, in promoting white settlement and diminishing the power of those who tended to be "quarrelsome with the settlers." 298

That Delamere put the shooting of African blacks on par with the dispatching of game animals is evidence of the racist mentality that prevailed in Eliot's administration and even carried over into Sadler's among the settler class. By January of 1907, racist feelings among the white settlers were running at a fever pitch, culminating in the election of Captain Grogan as the President of the CA.299

In 1908, Delamere and the settlers' frustrations with the status of labor provision were ever-increasing. In the EAP, beside the ongoing question related to the adequate transfer of land, the provision of a sufficient and reliable labor force for the expatriates was a puzzle that the administration had to sort out. Such would not have been the case

297 Jackson to Clement Hill, private correspondence, 25 May and 4 August 1903, FO 2/720.

298 Ibid. and Eliot to Landsdowne, telegram, 16 April 1903, FO 2/719.

299 Bennett, "Settlers and Politics", 276. 
if there were no European settlers in the region. The problem stemmed from the policy formulation of the second administration after the completion of the railways. "With the decision of the protectorate's second commissioner, Sir Charles Eliot (1901-4), to permit and encourage white settlement, the employment pattern hitherto coastal and railway began a total change. Settlement involved three major labor problems: to obtain men either by recruitment or compulsion; to retain them, in the local context to prevent them from deserting; and to make them work diligently. All three problems were to lead to incessant conflicts and to crises in 1908 and 1912-13." 300

There was another dilemma in the EAP, which consisted on how to manage a situation where Africans had to work for themselves and for the colonists while being also taxed. Another paradox was that when all the best land was alienated, it limited the African holdings. And adding insult to injuries, the European settlers were not keen with the idea of establishing reserves for the Africans. Reserves for the local population meant that they could remain far from the latecomers' sphere of influence. The settlers were astute because they wanted to have the African segmented in small groups with insignificant holding so that they would benefit from the new setting by obtaining abundant cheap labor. That strategy was an illustration of the process of ghettoization and exploitation.

It should be no surprise that the issue of labor supply was going to be a problem, when the origin of settlers and their mentality is taken into account. The colonists were invited to the EAP; land had been alienated to the benefit of the invitees, the acquired properties needed to be developed and a labor force established. This was easier said

300 Clayton and Savage, Government and Labour, 20. 
than done. The colonists, who viewed the Africans as passive, seemingly were not apt to carry the task of developing their acquired land. Long hours working under the sun was deemed impossible for the colonists to bear. This was a lame excuse and an exaggeration. When the protectorate opened, the first European who crisscrossed the region praised its quasi-temperate climate and beautiful highlands as suitable for European settlement. The EAP was talked about as a Nova Scotia. After the first phase of settlement on the highlands, there was an immediate need for labor. The settlers postulated that they needed the Africans to work for them. They wanted to assume a role of master with plenty of docile servants.

Assuming the role of master in the early days of the protectorate was not a big challenge for the settlers. The situation in the EAP was unique because the region had experienced natural calamities that affected the local population. When the Europeans arrived, recovery was just catching steam. The Africans were starting to get back on their feet. The last thing they needed after the pacification phase or, perhaps we could call it the "hammering period," was having to leave behind their families, crops, and cattle to work for European masters who were not even willing to accommodate and pay them right. Testimony before the Native Labor Commission of 1912-13 helps to illustrate these conditions. A witness claimed:

There were well-known cases of employers who, engaging labourers for a month's work, became increasingly severe at the end of the month approached. A few days before pay days, some display of ferocity or injustice, resulted in the whole, or a large portion, of a gang of labourers absconding quietly at night from employment which had become intolerable. Alternatively an impossible task of work might be set, and the natives discharged for not completing it. The employer in extreme cases, secured the labour of upwards of 200 men for 25 days without payment to any of them.... A common practice among European employers was to withhold a portion of the labourer's earned wages when pay day 
arrived.301

These practices evidenced the reasons why there was no incentive for the Africans to work in European farms and that became a problem that led to the labor troubles in the EAP. Added to this, 1908 marked the peak of European settler immigration to Kenya before 1914. These newcomers competed with earlier arrivals for African workers Some "280 Transvaal Boers" arrived in the protectorate in 1908.302

In that scenario, the now-settled colonists considered the Africans as the available work force for the task. When confronted with the question of remuneration for the provision of that labor, the newcomers quickly figured it out. According to the big men of the likes of Delamere and Grogan who had vested interests in settling in the EAP, taxation was the answer. Putting the Africans to work and taxing them would economically lift the protectorate and in the same process awake the lower races from ignorance and laziness. This was a whole new plan of economic development that could only work, not in a free market, but in an established white men's country. As Clayton and Savage explained this situation:

In economic terms white settlement meant an injection of white capital, or capital in the form of skills, for development. This capital was spread over a large number of small projects, most of which in themselves were without sufficient cash capital. Apart from market-gardens around Nairobi large-scale farming was necessary if profits were to be made. To clear the ground, in the absence of skills and equipment, the farmer was obliged to seek a sizeable labour force of several score, sometimes several hundred men to work with their own rudimentary instruments. But the capital necessary for such a labour force was beyond the reach of most of the new settlers, whose difficulties worsened by the high interest rate charged by banks on loans. The situation was neither an economic climate in which the interest of labour was likely to flourish nor the labourer likely to receive a wage which genuinely and permanently attracted him. The

\footnotetext{
${ }^{301}$ Native Labour Commission's Report, Witness No. 86 as quoted in Ross, Kenya from within, 91. ${ }^{302}$ Simon S. S. Kenyanchai," European Settler Agriculture," in An Economic History of Kenya, ed. W. R Ochieng and R. M. Maxon (Nairobi East Africa Educational Publishers, 1992), 134.
} 
attitudes of the settlers themselves to their labour reflected these difficulties.303

Nevertheless, the colonists wanted cheap labor no matter how. To their way of thinking, they found a way to justify their claim. Some radical leaders of the CA had long nurtured a disdain towards the Africans whom they regarded as passive with no incentive for work. It was Grogan who proposed an outrageous solution to the labor question in his early days in the protectorate. In his memoir he stated the following: "A good sound system of compulsory labour would do more to raise the nigger in five years than all the millions that have been sunk in missionary efforts for the last fifty.... Then let the native be compelled to work so many months in the year at a fixed and reasonable rate and call it compulsory education, as we call our weekly bonnet parades church. Under such a title, surely the most delicate British conscience may be at rest."304 There was no doubt that Grogan's suggestion was a bold and inflammatory proclamation with no moral validity. He simply suggested a system of forced labor and such was the point of view of the majority of the settlers who held land waiting to be developed.

To the colonists in the protectorate, Grogan's idea of Africans working for European settlers without complaints was brilliant because such a system would provide the locals with a good education. The only thing that was needed from that labor force was total submission. "The natives', says the planter, 'evince a great reluctance to work, especially to work regularly.' 'They must be made to work,' say others. 'Made to work for whom?' we innocently ask. 'For us, of course,' is the ready answer; what did you think

303 Clayton and Savage, Government and Labour, 20.

304 E. S. Grogan \& A.H. Sharp, From the Cape to Cairo, (London: Hurst and Blackett, 1900), 360. 
we meant?"305 From that observation of Churchill, it was not difficult to understand that the colonists wanted an implementation of a quasi-free labor as a fait accompli, but the obstacle in front of them was that the extant government, ipso facto, could not satisfy their pleas.

By November 1906, and as a result of the recommendations advanced at the January 1905 meeting of the CA, ${ }^{306}$ such a proposed Masters and Servants Ordinance had still failed to prove acceptable to Elgin insofar as it was patterned too closely after some South African enactments. 307 However, with the arrival of 1907, one suggestion of the Land Committee was acted upon, that being the appointment of a Secretary of Native Affairs in the EAP, whose express duty was to be that of dealing with the "labour supply."308 At first glance, this may have seemed exactly the type of African labor department that the settlers were looking for; but the new secretary, A. C. Hollis, had other ideas. He was clearly on the side of the African workers and did not wish for them to be exploited in any way by the settlers or any other employers.

Upon inspection, Hollis found many labor abuses that needed to be addressed. What distressed him most was the failure of employers to feed their African workers at the end of a contract or even provide them with return transportation to their homes of record. In his efforts to change these and other sorry conditions of employment, he did succeed in getting Sadler to issue a regulation providing for the feeding of employees upon discharge. However, as to transportation and any concerns related to recruitment

305 Observation of Winston Churchill, quoted in Clayton and Savage, Government and Labour in Kenya, 20.

${ }^{306}$ For details of the meeting see Clayton and Savage, Government and Labour in Kenya, 32. 307 Minute by Elgin, 2 November 1906, on Jackson to Elgin, 20 August 1906, CO 533/16. ${ }_{308}$ Minute by Lobb, 17 July 1907, on Sadler to Elgin, 11 June 1907, as quoted in George Bennett, Kenya, $A$ Political History, (Nairobi: Oxford University Press, 1963), 25. 
methods and other terms of service, no headway was made by the time that Churchill personally arrived in the EAP in October 1907 to check out the dire African labor situation. On his way from Mombasa to Nairobi, Churchill took note of returning African workers in a bedraggled condition, plodding their way slowly along the railroad tracks, attempting to find their way their home on their own after completing some labor contract. Of course, Churchill investigated this situation in some detail and upon his arrival in Nairobi, bombarded Sadler with endless questions regarding the lack of a suitable EAP labor policy to protect these workers.309

Beside personal meetings with Sadler and Hollis, individually and jointly, Churchill put forth his recommendations in writing to address any labor shortcoming that he perceived in the protectorate. Clearly, Churchill did not trust the settlers when it came to treating their African laborers with any sense of fair play. In his formal letter, he appointed K. R. Dundas to assist Hollis in the work of generating new rules that would protect these workers' rights.310 Churchill's recommendations were ultimately approved by Elgin, who noted to Sadler "these arrangements appear to me to be absolutely necessary unless some very shocking scandal in the employment of contract labour is to occur."311 As Churchill had returned to London, Dundas, Hollis and Sadler were left with the task of implementing laws that would help protect at least some of the African workers' rights. This they managed to incrementally accomplish, despite the growing consternation of the settlers, who by March of 1908 had grown so fed up with

\footnotetext{
309 Mungeam, British Rule, 192.

${ }^{310}$ Minute by Churchill, 11 November 1907; Memorandum on the meeting of 13 November between Churchill, Sadler and Hollis; Circular to Provisional Commissioners from Jackson, 18 November 1907; and enclosures in Sadler to Elgin, 26 November 1907, CO 533/33.

${ }^{111}$ Elgin to Sadler, 5 March 1908, CO 533/33.
} 
the government's perceived anti-settler positions that they were marching on the Government House.

Sadler's administration had put forward a code of conditions by which the Native Affairs Department was willing to assist in locating labor for the settlers in exchange for an enforced ban on the violent and compulsory methods previously utilized in filling ever increasing labor shortages. Lord Delamere called a special meeting of the CA in March 1908 to demand that the government pass a motion that would abolish these new labor regulations. Sadler would not take any immediate action, but did promise that he would at least consider the "relaxation" of some of the provisions. Delamere, totally unsatisfied with Sadler's response, led a demonstration of some one hundred settlers outside Government House in Nairobi, calling for Sadler's resignation. $3^{12}$ On the following day, Sadler met with Delamere and a delegation of the CA. He steadfastly refused to withdraw the regulations, but he did appoint a board of inquiry to look into the matter. 313

The elitist Delemere was envious of Grogan's popularity in the white settler group. One can easily see that Sadler's perspective on the demonstration was correct: Delamere used it to rile up the disgruntled settlers, so often frustrated in their attempts to eke out a meager existence off the land but too proud to do any back-breaking work themselves. If the settler, therefore, thought of the African worker as inferior to himself, then he had no problem in forcing this worker into compulsory labor and further abusing him in the process. He would never have to treat the black worker with respect as in the white settler's mind the black was in no position to demand equal rights. That

${ }^{312}$ By this time, Delamere was a member of the first Legco, though he had already submitted his resignation in December 1907 only to later withdraw it. Huxley, White Man's Country, 211-212. 313 Hyam, Churchill and Elgin, 412. 
the Sadler administration might, even inadvertently, change this paradigm was completely unacceptable to the white settler class, and Delamere was going to milk it for all it was worth.

Consider Sadler's commentary on the matter: "The whole thing is due to political agitations working on certain amount of distress among poorer settlers. The demonstration was the result of Delamere's ungovernable temper and of excitement of meeting after lunch at which he presided, subsequently conducting the mob up to my house. At this meeting a resolution was framed but afterwards withdrawn, calling on me to resign unless I immediately acceded to their demands." 314

Sadler, with his strong military background, thought it incomprehensible that a loyal subject of the realm would challenge the law in such a public and disgraceful display, especially enlisting the aid of Boers and their sympathizers in the process. The CO was cognizant that white settlers in the highlands, for the most part, were not making a lot of money and many had even abandoned their farms and stations. In their desperation, these settlers were turning back to some of the same tactics employed in South Africa such as forcing the Africans to work by direct compulsion or outright appropriating their land or cattle. And when such maneuverings were carried out in South Africa or other parts of the far-flung British Empire, the Crown was quick in taking actions to bring these activities to a cessation, even if troops had to be deployed in military engagements to make this happen. W. D. Ellis and others in the CO were growing weary of white settler abuses upon the African population in the EAP, and following Delamere's demonstration in Nairobi urged the British government to come

314 Sadler to Elgin, telegram, 26 March 1908, CO 533/42. For full accounts of the demonstration and impact, see: Great Britain Correspondence relating to Affairs in the East Africa Protectorate, Cmd 4122 (London: HMSO, 1908). E. A. S., March-April 1908. 
down hard on these political opportunists. The idea of white repatriation was actually given an impetus following the Delemere incident,315 but by the advent of World War I had to be sidetracked in order to enlist white settler aid in countering German influence in the south. Said Ellis: "These methods have led over and over again to wars in the Cape and Natal: and it would probably pay the British taxpayer to repatriate all of the whites and forbid their entry except on payment of a heavy poll tax. Such a cost is, however, impracticable....” 316 The Liberal government in London was clearly apprehensive about white settlement in Africa, and particularly noted that the EAP was its most "troublesome" of the new responsibilities on that continent.

Lord Elgin, the Secretary of State in Campbell-Bannerman's Liberal government, frequently expressed his concern about the proliferation of so-called "white men's countries" throughout the British Empire. ${ }^{17}$ It seems that just because a country has certain advantages as far as natural resources, the Empire was allowing and even encouraging unlimited immigration there. After opportunist individuals like Delamere arrived in Africa, however, the authorities in the $\mathrm{CO}$ began to take a dimmer view of the situation. Initially, they thought Delamere and other settlers would help the empire in the task of introducing regulation and order in all departments. What a surprise it was when these settlers, from all walks of life, i.e. peers to commoners, ended up siding with the racist Boers. By the time Lord Elgin turned over the CO to Lord Crewe in 1908, he had come to the conclusion that he and others in the Liberal government had failed in

\footnotetext{
315 Hyam, Churchill and Elgin, 413.

316 Ellis, Minute of, 1 May 1908, CO 533/43.

317 Hyam, Churchill and Elgin, 408.
} 
their duty to the EAP and especially to the "natives who inhabit parts of it, and I suppose, formerly owned the whole.”318

\section{Labor troubles and significance of Delamere's incident}

Looking at the constant labor demands from the settlers' camp, one could clearly see the problems that the protectorate was facing and that had repercussions on the development of the region. The EAP was a political mess riddled with discontent and agitations caused by the demanding colonists and for that reason, a permanent attention was needed to keep it from falling apart. The $\mathrm{CO}$ and the local administration had to be on the same page to make sure that the protectorate would not completely fall in the hands of the settlers. Meanwhile, the leaders of the colonists wanted to be a force to reckon with. Delamere stood up to challenge the governor and that had a considerable significance.

Delamere's reaction was swift. He took Sadler's refusal to withdraw the law so personally that he decided to directly challenge him.319 Since Grogan's incident, Delamere placed himself as the rising star and leader of the settlers. He spearheaded a famous settler revolt. The issue revolved around Sadler's decision to introduce new labor rules. The rules were to protect the African workers from abuses, because by enforcing them, a more fair provision of labor contract would be limiting the settlers from breaking the law by mistreating their employees. Delamere's actions weakened Sadler's position. It was a political maneuver that benefitted the settlers. Delamere raised political dust and could have never foreseen the impacts because party politics was flown into chaos for the coming decades in the political history of Kenya. Sadler

${ }_{318}$ As quoted in Ibid., 410.

${ }^{319}$ According to Huxley, the main grievances of Delamere and European settlers were related to "land, stock thefts, railway policy and labor," Huxley, White Man's Country, 190. 
had to leave the protectorate because the settlers wanted a man reminiscent of Commissioner Eliot. Delamere's actions were aimed at enforcing the Africans to work, but also, it was a message to the Indians in the region. The colonists nurtured a disdain vis-à-vis the Indians who also thought of settling in the highlands and feared their competition. To contain that threat, they pushed for the isolation of the Indians in the lowlands. The incident also stopped all prospect of cohabitation in the region while the pending land and labor issues were yet to be resolved. Following the demonstration, Delamere was suspended from the Legco, but that would not change the colonists' mindset. Making noise and causing trouble were their strategies. ${ }^{320}$ The settlers wanted relaxed land and labor rules that would oblige the colored people to work without complaints. In other words they wanted to set the terms of land acquisition and labor provision by themselves, which was synonym to a minority enforcing new rules thereby, bypassing the governor and the authorities in London.

Any changes in land or labor policy were bound to raise a stink with the white settlers. The previous administrations of Eliot and Stewart reserved the Highlands for European settlement and gave them an "exclusive right" to this area largely because the deficit in EAP expenditures was borne by the British taxpayer and also because the white settlers who had come to the highlands did so with the understanding that it would be shared solely by other whites. Also, the huge influx of Indians into the EAP was a cause of some concern to the CA as they did not want this new immigrant group to impinge on their area of control in the highlands, and they voiced this concern to Sadler.

320 Delamere's response to Sadler following his suspension over the 1908 demonstration was dated, 2 April 1908. It is given in full by Huxley, White Man's Country, 229-30. 


\section{$\underline{\text { Indian Question }}$}

Always between a rock and hard place with the CA, Sadler took care in formulating his response. Sadler recognized that Asians played a key role in both the conquest and development of the EAP, but assured the members of the CA that he harbored no intentions of reversing the policies of Eliot or Stewart with respect to the highlands. The concerns of the CA were advanced at a general assembly in May 1906, and they wanted Sadler to state in writing that the Indian policies of prior administrations would not be reversed insofar as highlands settlement was concerned. Nevertheless, Sadler would not be bullied by the association, and said that he was not going to guarantee the highlands solely for whites by legislation, but would follow "in principle" to guidelines for settlement established by Eliot and Stewart of not granting land “outside municipal limits" to Indians. ${ }^{321}$

While Ellis and others in the $\mathrm{CO}$ were not in accordance with excluding any class of His Majesty's subjects from holding land in any part of a British protectorate, including the EAP, they were willing to keep in mind the "comparatively limited area suitable for European colonization" there. ${ }^{322}$ This produced the first "Elgin pledge" that reserved a portion of the highlands between Kiu and Fort Ternan on the railway for exclusive European settlement by administrative action rather than legislation. ${ }^{323}$ Of course, the white settlers were grateful for this small concession, but they still wanted a firm guarantee, in writing, that the Highlands were going to remain forever under white

\footnotetext{
${ }^{321}$ Sadler to Elgin, 21 May 1906, enclosing letter from Secretary of Colonists' Association and resolutions passed at meeting of 9 May 1906, CO 533/14. 322 Elgin to Sadler, Confidential, 17 July 1906, CO 533/14. 323 Robert M. Maxon and Thomas P. Ofcansky, Historical Dictionary of Kenya Third Edition (Lanham, MD: Roman \& Littlefield, 2014) 91-92.
} 
control. What the CA wanted was the total exclusion of Indians from the Highlands area and even from any representation on the Legco.324

These Elgin Pledges, made at the behest of the European settlers during Sadler's administration, proved a very critical aspect of the Indian Question in Kenya history. So also did the issue of Indian political rights in the EAP. In 1907, for example, Churchill, specifically challenged Sadler on the omission of Indians from the Legco on the basis that "there can be no reason for excluding this large and meritorious class." ${ }_{225}$ Churchill was of the opinion that the appointment by Sadler of an Indian to the Legco would serve to instill, from its outset, good principles in the EAP. Sadler had no name to immediately suggest for a seat on the council. Rather, he operated from the assumption that if he did nothing he would do nothing wrong. But all that he accomplished was to raise the ire of the Indian community of the EAP that in April of the following year sent him a petition for a nominee to the council. Then Sadler recognized that the Indian community projected "legitimate claims," yet he still sat on his hands and pretended that all was well in the protectorate. The first Indian to be named to the council was A. M. Jeevanjee in 1909, and his nomination was put forth by then Acting Governor Jackson. Sadler was on his way to a new post as Governor of the Windward Islands, having been demoted for his overall tepidness. 326

After the protest, the concerns were clear. The Liberal government recognized that Asian immigration to other parts of the empire was a growing problem, and

\footnotetext{
324 In March 1908, the CO made a second pledge that "as a matter of administrative convenience" land grants in the highlands should not be made to Indians, though there would be nothing legislated to accomplish this restrictive land policy. Ibid., 92. See also Robert G. Gregory, India and East Africa, (Oxford: Clarendon Press, 1971), 80-87.

325 Minute by Churchill, 11 June 1907, on Sadler to Elgin, telegram, 21 May 1907, CO 533/29.

326 Bennett, "Settlers and Politics in Kenya," 280-281.
} 
particularly so in East Africa. White prejudice was probably more intense against immigrant Indians in the EAP than Africans. Clearly, the EAP was no Australia or even South Africa, as the members of the CA would have preferred it to be. But Elgin and others in the $\mathrm{CO}$ were at least willing to concede, in principle, that the highlands could remain a European enclave while Asian immigrants, most notably Indians, could be encouraged to trade and settle in more tropic climates. 327

At least from the start of construction on the Uganda Railway, Indians in East Africa had sought, as British subjects, to gain equality of treatment and standing in the country of their adoption. Besides the white settler class, many Africans were also opposed to their settlement and the so-called "Indian question" has been a recurring theme throughout the region's history. During Sadler's administration, the Asians held the majority of the skilled or semi-skilled artisan jobs and were found as small traders throughout the country, much as they still are in contemporary Kenya. In many instances, the African has felt crowded out by the strong Asian immigrant presence. The whites, on the other hand, also feared the Asian presence for the economic and political threat that they posed. Being non-white, the European mentality reasoned that the Indian or some other Asian may form an alliance with the blacks against them. This mode of thinking was pure paranoia, of course, but when the white settler community shunned Chamberlain in favor of extremists like Grogan and Delamere, what more could be expected? Thus a decade later the Indian Question emerged as one of the key issue facing British rule in Kenya.

327 Hyam, Churchill and Elgin, 417. 
Sadler consistently pushed Elgin and others in the CO for a legislature in which more Europeans were represented in order to get the CA off of his back. Because His Majesty's Imperial government certainly wanted to guarantee the rights of all British subjects in the EAP, regardless of race or ethnicity, a trusteeship power was granted to the Governor to make it so. This resulted in what may essentially be referred to as a dual political system. Thus, in the Highlands the white settlers gained a dominant influence over important areas but were blocked by the Liberal government in London from actually realizing the self-government they so desperately yearned for. More so in the Sadler administration, this dichotomy led to a stalemate over the EAP's projected political course and development. Insofar as the Africans were concerned, Sadler acted as nothing more than an authoritarian and paternalistic guardian whose only success was in at least keeping the white settler class from overturning what few laws were laid down to protect the black worker. And as far as the Asian-Indian community was concerned, total inaction was the order of the day. The situation in the protectorate was no longer sustainable and the $\mathrm{CO}$, once again, had to intervene. $\underline{\text { Conclusion }}$

The EAP was a region invaded by a few colonists who turned the region into a political nightmare. The EAP was difficult to properly administrate. In 1909, The CO grew tired of Sadler's inaction. He did not finish his term as governor. The CO originally appointed him because of his military background, hoping Sadler would bring some backbone to the situation and put the settlers in check to allow for the gradual uplifting of all His Majesty's subjects throughout the EAP. Thus the CO felt the need to bring in a stronger man from outside, and that was Sir Percy Girouard. Here was an administrator 
who had performed a great work in reestablishing functional control in Northern Nigeria.

That Sadler failed to reestablish functional control in the EAP may be due to the "grilled cheese" political effect, with Sadler being the cheese. On one hand, he had to answer to the Liberal government's CO, whose officialdom from top to bottom, including administrative staffers in foreign outposts, were largely controlled by the "Oxbridge" elites, i.e. graduates of Oxford and Cambridge. In the EAP, for example, between 1890 and 1909, of the known social backgrounds of 22 EAP administrative officers with university degrees, ten hailed from Oxford and 3 from Cambridge. There were none from South Africa or other Commonwealth countries. And of these 22, four hailed from military and technical academies. ${ }^{328}$ This group formed the bottom slice of bread upon which the slice of cheese rested. And then came the top slice. This was the lousy settler class, mostly composed of white South Africans, principally Boers.

On the concept of subject races, the South African John Buchan has penned: "The root of the trouble is that England and South Africa talk, and will continue to talk, in different languages.... The Englishman, using the speech of conventional politics, seems to the colonist to talk academic nonsense; while the South African, speaking the rough and ready words of the practical man, appears as the champion of brutality and coercion. The difficulties are so real that one cannot but regret that they are complicated by verbal misunderstandings." 329 So here lies the crux of the matter.

\footnotetext{
${ }^{328}$ Bruce Berman, “Administration and Politics in Colonial Kenya," (Phd dissertation: Yale University, 1973), 97.

329 John Buchan. The African Colony: Studies in the Reconstruction (London: William Blackwood and Sons, 1903), 284.
} 
Sadler needed to pick one side and go with it, and not try and placate both sides. For in the process of doing so, he was aptly grilled and consumed.

Here it could be said that the Europeans settlers succeed in maintaining pressure and disorder that had the governor cornered in a middle of political storm. The EAP remained economically stagnant and politically divided with a majority population that stood without representation. The governor failed to strike a balance between the wishes of the $\mathrm{CO}$ and the interests of the colonists in the region. Instead, there was chaos that held back the region from a peaceful economic take off. A clear policy formulation was long overdue because the Africans and Indians living in the region could not be written off. They also needed land and fair rights to compete and prosper. Changes were needed for a better administration of the region. Once again, it was time to reshuffle. Mungeam summarized:

By the end of 1908 it is difficult to avoid the conclusion that the Protectorate as a whole was suffering from a bankruptcy of ideas. Within the Protectorate, apart from the enthusiasm of Hollis in the fields of labour and land, none of the senior officials appeared capable of offering concrete ideas that might revitalize the country. The constant struggle with the settler population, the comparative lack of leadership at the top, the long years of service in the Protectorate, all combined to turn men of the seniority of Jackson, Hobley and Ainsworth into sound but somewhat unimaginative administrators. In Whitehall, important changes had taken place. Asquith's reshuffle of May 1908, which replaced Elgin and Churchill by Crewe and Seely, meant the loss of an Under-Secretary who had taken a keen interest in the affairs of the Protectorate. Indeed, Churchill was the one first-class man, amongst the many politicians concerned with the Protectorate in its early years, to have shown an active interest in its problems and to have taken the trouble to pay it a personal visit. 330

Nevertheless, the issues of land and labor regulation were still to be sorted out, and the newcomers were still not satisfied with the manner that the $\mathrm{CO}$ was supervising the protectorate. With the transfer of Sadler, the colonists were hoping for the CO to

\footnotetext{
330 Mungeam, British Rule, 204-5
} 
back up the right horse to run the protectorate for their interests. Their wish came through when the $\mathrm{CO}$ sent a railway engineer to for the job. With this quick fix, the troublesome protectorate was entering another era of political agitations and abuses on the expense of the colored people of the protectorate. 


\section{Chapter 5}

The peak of European settlers' political influence and interference in the East Africa Protectorate's administration under Governor Girouard from 1909 to 1912

Introduction

The period from 1909 to 1912 was the time that Sir Percy Girouard was the appointed governor of the EAP. The $\mathrm{CO}$ authorities who entrusted him with the mission of bringing order and getting things moving in the right direction in the protectorate had firm expectationsabout how Girouard would differ from the previous administrators. The CO expected him to deliver. Nevertheless, Girouard's administration turned out to be the biggest political train wreck the protectorate had ever witnessed. The governor embarked in dangerous liaisons with the politically active European settlers, who wanted privileges and power.

European settlers' politics in the EAP was an activity profoundly related to the issues of governance. Ross asserted that: "from the earliest days the Government of the East Africa Protectorate displayed commendable willingness to listen to advice from local European residents. Critics of a sardonic turn of mind might perhaps interject that it had no option in the matter, the advice having been tendered in such strident tones as to compel attention." $33^{1}$ The general tone was set during Eliot's administration, which created a context of political obligation to solely benefit the colonists, inviting them to take up land and develop the region. That was how the EAP's political stage ended up being heavily dominated by the influential European settlers since Eliot's resignation in 1904; the colonists in 1909 were hoping to have a similar man in the spot who would

${ }^{331}$ Ross, Kenya From Within, 167. 
stand for their interests like their political progenitor did. With the noisy European settlers always pushing for more concessions, the EAP struggled to find the necessary political stability for a steady economic development. This would turn into a pattern that left a mark in Kenya's colonial and post-colonial political history.

Since the departure of Hardinge, the protectorate experienced a succession of commissioners and governors who were sent to get things moving in the right direction. Peace, order and a just society were requisites for the EAP if it was to have any hope of economic development. Nevertheless, by 1909 it was clear that the EAP was a racially divided society with the Africans and the Indians being pushed off the political stage. This was indeed a far cry from the vision of Sir Harry Johnston that he expressed just after the completion of the Uganda Railway. Johnston stated that he "had long believed in the development of Africa in racial harmony and so could speak of this land also as a possible America of the Hindu." $33^{2}$ Unfortunately, as George Bennett noted, "the troubled story of racial politics in Kenya has belied his hopes." 333 What did become clear, however, was that the European settlers were not going to let the EAP become any sort of America, either for the Hindu or the African. The European settlers present in the protectorate did not want any form of political cohabitation. The political isolation of the Indians and the Africans was the only guarantee for the establishment of a successful self-governing white man's country. That simply meant segregation in the EAP could be the new reality. The European settlers' presence coupled with their ideology rendered difficult the very issues of governance in the EAP.

\footnotetext{
${ }^{332}$ Great Britain, Report by His Majesty's Special Commissioner on the Protectorate of Uganda, Cmd. 671 (London: HMSO, 1901), 9. 333 G. Bennett, "Settlers and Politics in Kenya, Up to 1945," in History of East Africa, vol, 2 Vincent Harlow, et al, eds. (Oxford: Clarendon Press, 1965), 265.
} 
After Sadler's difficult tenure, the CO sent Governor Girouard to assess the situation and recommend needed action. The $\mathrm{CO}$ wanted him to stabilize the region and implement fair policies that would economically benefit all parties, thereby reflecting well on the Empire. In compliance, Girouard reported back to the $\mathrm{CO}$ on the whole East Africa situation. However, he started off on the wrong foot, showing favoritism for the settlers. He wanted more European settlers and increased representation in the Legco, thus facilitating their active participation in running the protectorate. Girouard fell into the settlers' net. He came under Delamere's influence and became engaged in a dangerous political liaison that would ultimately result in his resignation in 1912. Girouard's governorship was far more open and flexible to the settlers' interests than even Eliot's administration was. The new governor totally discarded the rights of the Africans and the Indians. The Indian community felt isolated and protests came forth from them against the settler's political dominance.

With the deliberate backing of Girouard, the Convention of Associations (C of A) was formed in 1910. The C of A was the united settlers' party standing for all its members' interests in the region. The colonists' decision to come together as a one strong political party was evidence of their determination to use all strategies and tactics possible to defend their interests and achieve their goal of acquiring a self-governing country. Keeping the political context and climate of the EAP in mind, it is apparent that the colonists were developing broad strategies and plans for the achievement of goals, along with specific methods and tactics to carry out the same. The settlers' tactics included a claim for electoral participation, i.e., voting, campaigning, influencing public opinion, lobbying governmental and non-governmental agencies and associations, verbal protests, threats, mass action, demonstrations, marches, disruption, litigation, 
and even violence. All of this carried with it, of course, an intense focus on the expansion and internal development of the white settler community.

The European settlers had tremendous influence and confidence and did not hesitate in pushing for more concessions. So bold were the settlers that they came up with yet more demands in February and August of 1911. They demanded elective representation in the Legco, albeit it would still remain under the supervision of the CO. The settlers were not above employing violence to meet these ends, either, as we will note in the case of the murder of an African by Galbraith Cole, a settler related to Delamere, with the rest of the Empire be damned in the process.

As this chapter develops, it becomes apparent that the political situation in the EAP was unique. On one hand, the political challenges the settlers brought to the $\mathrm{CO}$ under Girouard's watch marked an era of extremes, led by a few agitators that Churchill once referred to as "political animals" 334 with the sole objective of turning the protectorate into a white men's country. Paradoxically, as far as the Africans and Indians were concerned, it was an era of political and economic disenfranchisement with all odds stacked against them. Less land was being made available for them and they had to pay taxes. Girouard went too far in favoring the colonists, even to the point that the Africans again suffered clear violations of their rights. In this instance, a promise was made to transfer some of the Maasai land to the settlers. With such violations sanctioned for the sole propose of favoring the European colonists, Girouard ended up like Eliot, tendering his resignation to the CO. Girouard's administration was a déjà $v u$, a worse facsimile of Eliot's tenure. It was an attempt to make the settlers'

334 Churchill, My African Journey, 31. 
interests paramount in the region. Nevertheless, the lesson to be drawn from his governorship was that the $\mathrm{CO}$ was still in charge and the European settlers' political dreams and goals were yet to be realized.

Sir Percy Girouard as the new man in the spot

In 1909, the CO came to the conclusion that it was time to remove Governor Sadler from the troublesome EAP. This was not a surprise. When it came down to matters related to who could best administer the protectorate, the $\mathrm{CO}$ had a method that consisted on shuffling servers of the crown from one protectorate or colony to another. It was a quick-fix designed to be utilized at any time that they realized that they had the wrong man in some trouble spot.

Officials at the CO came to the realization that Sadler had bitten off a little more than he could chew in governing the EAP. For in 1909, one year prior to his scheduled transfer from the governorship of the protectorate, Sadler received and accepted an appointment as governor of the Windward Islands. These are the southernmost islands of the Lesser Antilles, a long chain of islands wrapped around the eastern end of the Caribbean Sea along the boundary of the Atlantic Ocean. Sadler himself seemed relieved to be leaving the constant turmoil that existed in the protectorate. The Windward Islands would prove to be a near Eden for Sadler. He was not anticipating any serious administrative difficulties in those remote Caribbean islands so neatly tucked away from the flurry of imperial machinations that existed in East Africa and other contentious areas of British global dominion. 335

335 Sorrenson, Origins, 117. 
Sadler's designated successor to the governorship was the French-Canadian, Sir Edouard Percy Girourard (1867-1923); and like Sadler, he was also a man of some military distinction. A graduate of the Royal Military College at Kingston, Girouard entered the British Army in 1888. Eight years later he participated in the Dongola expedition in the Sudan, whence he received the Khedive medal with two clasps. One year after that, he played a part in the Nile expedition and subsequently went to work in opening up and directing the operation of British railways in both Egypt and the Sudan. He was so effective in this position, that in 1899 he was transferred to South Africa, where he served as the Director of Railways until 1902 and the conclusion of the Second Anglo-Boer War. 336

Girouard demonstrated outstanding administrative abilities in the work of building and maintaining efficient railroad operations. From 1902-1904, he served as Commissioner of Railways in the Transvaal and Orange River Colonies. Girouard clearly respected the hard-working South African railway workers. Despite their political differences with the British Empire, Girouard expressed a grudging admiration for the hardscrabble settlers in South Africa. Following his South African service, Girouard served as High Commissioner and Governor in Northern Nigeria on the West African coast where the economy depended heavily on African peasants' agricultural production. During this time, most would have described him as a small yet dapper man, bursting with energy and self-confidence. His reputation as a gentleman with a

${ }^{336}$ Ibid and Abdullahi Daiyabu Sara, "Rush to Failure: The Governorship of Sir Percy Girouard, 19091912," (Ph.D. diss., West Virginia University, 2013), 28-40. 
remarkable flair for administration extended all the way to London, so naturally those in the $\mathrm{CO}$ were paying close attention to Girouard's rising star.337

Keeping in mind his dutiful service to the Empire, in 1907 Girouard was appointed to succeed F. D. Lugard as the High Commissioner and later Governor of Northern Nigeria. Girouard was ostensibly committed to carrying out Lugard's goal of the establishment of a dual mandate in Northern Nigeria and other areas of tropical Africa. ${ }^{338}$ Basically, the dual mandate entailed indirect British rule in colonial Africa. Lugard believed that such indirect rule would assist in facilitating the spread of Christianity in Africa, in addition to hastening the end of the more so-called "barbaric practices" that still ensued on the continent. Lugard believed that the British statesponsored colonization of African protectorates was one way to protect missionaries, local chiefs, and local people from each other as well as from foreign powers. For the far-sighted Lugard, it was vital that Britain gain control of unclaimed areas before France, Germany, Portugal, or any other European powers claimed the land and its resources for themselves. Lugard was of the opinion that there were vast profits to be made through the exporting of natural resources and through taxation of of the African populations, as well as importers and exporters. In addition, these resources and inexpensive African labor could be counted on to provide vital fuel for the industrial revolution in resource-depleted Britain as well as monies for public works projects. And most importantly, Lugard reasoned that colonization efforts would not need to be

337 Ibid.

${ }^{338}$ Sorrenson, Origins, 117; Sara, "Rush to Failure," 32-34. 
augmented if Britain were to retain its position as the greatest global empire in history. 339

The CO at best thought of Sadler's administration as weak whereas they viewed Girouard, a disciple of Lugard, as being fresh and dynamic. Here was just the type of firm administrative leader that could give the EAP the boost it needed to regain some of the luster lost during previous regimes in place in East Africa. They also viewed Girouard as the type of man who could be relied on to effectively deal with the settlers and their overwhelming South African contingent in the EAP. After all, his work with the railways in South Africa proved beyond a doubt that he had a way with the local population and could be relied on to build up the necessary momentum behind various projects. Here, it is worthy to mention that there were no settlers in Nigeria.

In most respects, Girouard was seen as the "best possible man" for the post.340 The CO believed that he could control the settlers while at the same time add the needed vitality to the EAP administration. His successful work on various colonial British railway operations also bode well for Girouard's economic guidance of the protectorate to the harbors of efficiency and profitability. ${ }^{341}$ So Girouard was heading to the British East Africa highlands with the CO high expectations that the new man in the spot will deliver and guide the protectorate to prosperity. There was hope of finally seeing the region generating revenues. The $\mathrm{CO}$ wanted a well-administrated protectorate where the European settlers would remain content with what they already had. The CO also

\footnotetext{
339 A complete elaboration on the dual mandate can be found in Lord Lugard, Frederick D. The Dual Mandate in British Tropical Africa. Fifth Edition London: Frank Cass \& Co. Ltd. (1965). Original published in 1922.

340 Crewe to Girouard, 20 June 1909, CO 533/67.

${ }^{341}$ Sorrenson, Origins, 115.
} 
wanted an extension of the pax Britannia in the region and that meant the safeguard of all subjects' rights under the crown.

$\underline{\text { Sir Percy Girouard's general constats de faits of the protectorate's status quo and his }}$ inclination towards the European settlers

Upon taking over the governorship of the protectorate, Girouard was ipso-facto shocked by the fact that there was no clear policy for an effective administration of the region. There was still the familiar issue of reserved land for the settlers to be defined. The need to protect the African and the Indian population was also crucial. Looking at the situation, Girouard realized that the settlers were not sympathetic with the incorporation of the Indians in the emerging economic system. Adding to that reality, they considered taxing the Africans as a way to generate revenue while securing labor. The expatriates from South Africa had gained such influence that any official sent in the protectorate was expected to side with their association. The settlers had the habit of scrutinizing any commissioner or governor sent by the $\mathrm{CO}$ in the EAP. Failure to come under the influence of the main leaders of the settlers was like opening the gate for troubles. The $\mathrm{CO}$ wanted to avoid further disturbances from the expatriates' camp. Unfortunately, Girouard fell under Delamere's influence, which was a recipe for more conflicts under the watch of the officials of the CO.

By sending his first alarming reports to the $\mathrm{CO}$, the new governor took a stand for the European settlers. In his 1910 report of the protectorate, for example, Girouard showed clear signs of being aware of the role that he wanted the colonists to play in the political arena of the region. The governor went on to criticize the state of the protectorate and the officials in place. He complained about the lack of a definite policy to lift up the protectorate and generate revenue. 
Nevertheless he seemed to only consider the settlers as an alternative for change. Girouard suggested to the $\mathrm{CO}$ "that a strong administrative machine should be created and that the settlers should be given the opportunity for greater participation in government." $342 \mathrm{His}$ references to the Legco made plain how strong the settlers' influence had become: he wanted a strong colonial secretary to give lead on the council, where he found the officials weak both in numbers and in debate. But he wanted more European unofficial members there also, for their active participation in government was 'essential'."343 Girouard quickly came to the realization that European settlement was a reality that could not be ignored. Settlers' participation in the development and administration of the protectorate was unavoidable. But, the problem here was that the colonists were not the majority capable of developing the region. They did not want to work or pay taxes, and many of them lacked the resources or skills necessary for their new adventure in East Africa. The settlers' stand was to play without having to pay and that meant representation without taxation. Girouard did not realize that at first. The reason why Girouard sympathized with the settlers had nothing to do with his personal record, but one is driven to consider his experience with the South African settlers as a factor.

342 Mungeam, British Rule in Kenya, 217. Girouard forwarded his main report on the EAP to the CO in May 1910.

343 Bennett, "Settlers and Politics," 281. 


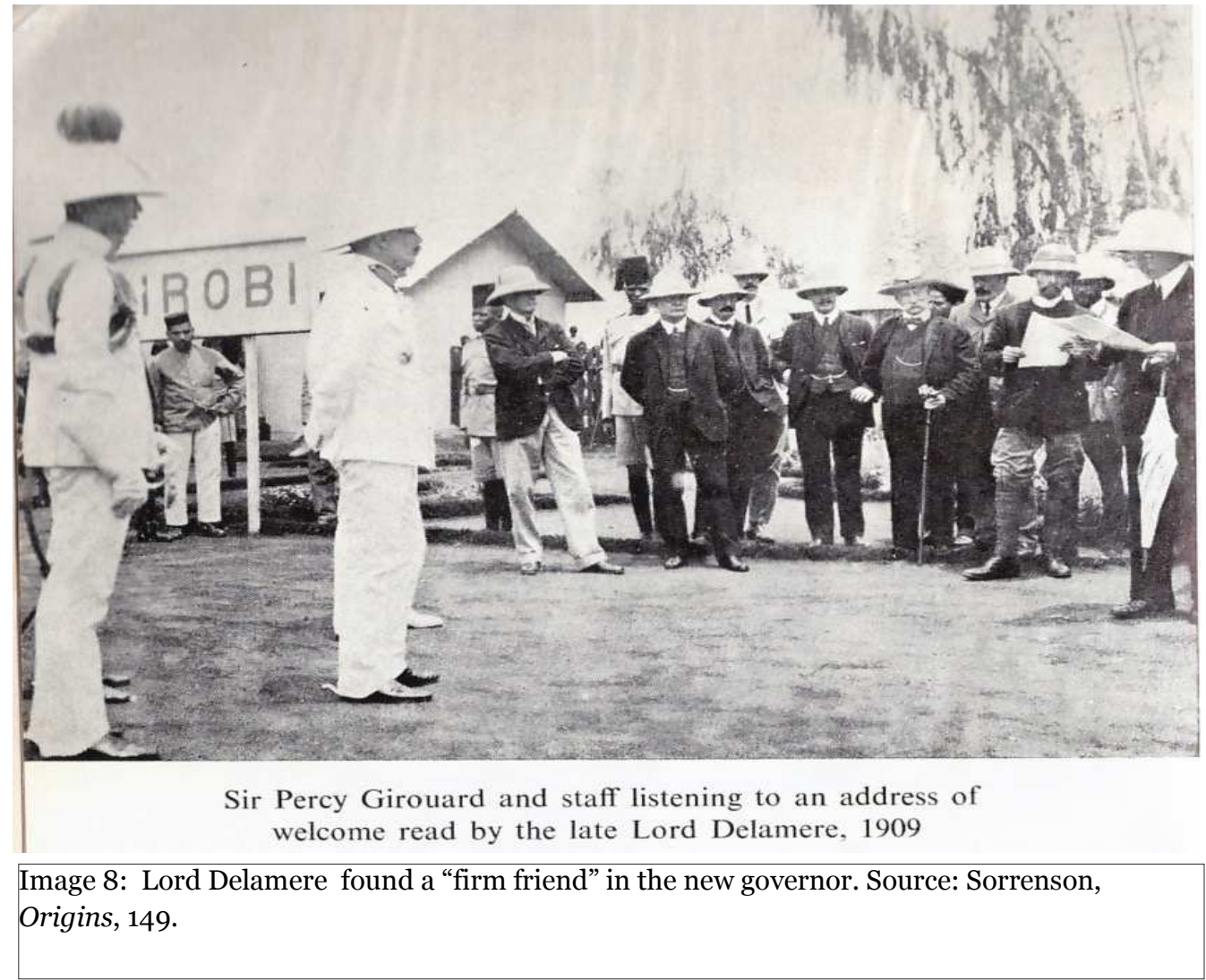

\section{Liasons dangereuses, Girouard and the European Settlers' alliance}

This combined with the fact that Girouard soon found a firm friend in Lord Delamere and engaged in political actions favoring the settlers. That alliance turned into a huge fiasco, a massive political train wreck. Girouard made the false assumption that Delamere would become his "firm friend."344 Girouard made the overture of sending a telegram to Secretary of State, Lord Crewe, wherein he recommended that Delamere be reappointed to the Legco, from which body he had resigned in May 1909. In this same telegram, Girouard questioned the presence of A. M. Jeevanjee, the leader of the Indian faction in the EAP, on the Legco. Girouard could have argued that Jeevanjee was largely illiterate, and the position called for a more educated and hence 344 Ibid., 282. 
articulate spokesman. But his rationale for the challenge was that other ethnic groups, like the Arabs and Swahilis, who outnumbered the Indians by a two-to-one margin in the protectorate, would soon be demanding representation on the council for their particular factions. For if the Arabs and Swahilis, who so outnumbered the Indians, were deserving of knocking out the Indian representative, what of the white settler representative whose constituency numbered but a few hundred?345 Once again, it appears as though Girouard acted too hastily. Had he checked with the published official gazette, he would have noted that official recognition for Jeevanjee had already been granted in London and that it was too late to do anything about it. ${ }^{346} \mathrm{He}$ also tipped his hand and inadvertently revealed his racist tendencies by demanding that Jeevanjee be dismissed from his legislative post.

The Indians were mostly ordinary working class, the actual builders of the railroad. They were very industrious and could perform works vital for the development of the region. Among them, there were mainly traders, masons, carpenters, porters, clerks, and surveyors. They served the protectorate well, working in many different areas like road construction, post offices and customs. In fact, many Indians adapted well to East Africa and did not feel the need to return back home. Indian agglomeration in the growing cities was economically considerable and quite noticeable. As Bhatt noted, "According to the earliest census carried out in the protectorate in 1911, there were approximately 11,00o Indians in the country. In Nairobi with a population of 14,161, Indians were 3,171 while 591 were Goans. The rest of the population comprised

345 Bennett, "Settlers and Politics in Kenya," 282.

346 Girouard to Crewe, 23 September 1909, and Crewe to Girouard, 2 October 1909, C.O. 533/62. 
of 799 Europeans, 76 Eurasians and 9,524 Africans. Mombasa's Indian population was 3,820."347

Although many Asiatics were not keen on becoming cash crop agriculturists, the vast majority opened bazaars along the railroad and other trade routes, developing profitable businesses. Indian small businesses reached many corners of the protectorate. They were mainly established in the growing urban centers like Nairobi, Machakos, Kisumu, Naivasha, and Kisii, just to name a few. They ventured and traded in rural areas that provided markets for some farm produce like dairy products, beans, potatoes and more. They were also successful businessmen who prospered in the EAP where many European settlers could not even scratch the surface yet, despite possessing the best land. Bhatt pointed out that: "A.M. Jeevanjee, and Allidina Visram had established vast business empires that covered much of East African region. Others included Adamjee Alibhoy who had been invited to Machakos by the provincial Commissioner for Ukamba Province, John Ainsworth in 1898 to establish a retail outlet; Gulamhussein Abdulah Datto who established a successful auction business in Nairobi; Deroda Shami Harji who established a succesfull construction company in Kisumu, among others." 348

The CO was cognizant of the Indian contributions in East Africa. In fact, the Indian rupee was used as the official currency since 1898. And according to Mangat, it replaced "the Maria Theresa dollar which had been operational until this time, and in 1910 the National Bank of India became the official bank of the protectorate."349 This

347 P. M. Bhatt, “A History of Asians in Kenya, 1900-1970" (Ph.D., diss, Howard University, 1976), 18. 348 Ibid., 72.

349 J.S. Mangat, History of Asians in East Africa c. 1886-1945 (Oxford, Clarendon Press, 1969), 77-87. 
was not well welcomed by the settlers who wanted everything to be modeled in conformity to the English system back home.

The Asiatics were important contributors in the economy of the region and some British officials who visited the protectorate took notice. Sir Edward C. Buck, Secretary of the Department of Revenue and Agriculture in the Indian government, witnessed the important involvement of the Indians in East Africa since 1905. Also Churchill, on his visit to the protectorate in 1907 , noticed the tenacious character of the Indians and was of the opinion that they deserved a fair political representation in its administration. But when it came to Girouard, he seemed to have not realized the valuable contribution of the Indians. He failed to recognize the importance of the Indians in the region. For a man of his experience, this was a big misstep because the Indian presence was manifest almost everywhere in the protectorate. The governor paid more attention to the small European settler community. He was a bold, but shortsighted, governor.

With Girouard as the locomotive engineer, he was now full-steam underway to the carrying of his settler passengers to their homes in the "white man's country" he was going to carve out for them in the highlands. The settlers needed a free ride to the Legco. This was utopia because so far the settlers' contribution in the economy of the region was quasi-insignificant, and they feared the Indian competition. They viewed the Indians as a force that was quickly proliferating and could, with all due justice in mind, stand for their rights. If deprived of representation and ignored, the Indians would eventually rise up for their rights. Churchill foresaw the danger of a possible isolation of the Africans and Indians earlier in his visit to the region. He was against the opinion that the protectorate could ever become a white man's country in the sense of Canada or the United Kingdom. Confronted with the conflicting claims of European, Indian and 
African, he argued that the tropical protectorates were big enough for all, that a place could be found for the European settler and for the Indian trader and agriculturalist in a country that fundamentally belonged to the Africans. Churchill understood the complicated social context of the EAP and wrote the following: "In truth the problems of East Africa are the problems of the world. We see the social, racial and economic stresses which rack modern society already at work here, but in miniature ... The British Government has it in its hands to shape the development and destiny of these new countries and their varied peoples with an authority and from an elevation far superior to that with which Cabinets can cope with giant tangles at home. And the fact stirs in mind." 350

Nevertheless, the governor had a different view of the situation. Girouard believed that the small group of whites was entitled to representation on the Legco solely based on their race. Nothing else makes any sense, given what we know about this situation. The reasoning behind Girouard's position with regard to Jeevanjee actually served to undercut the right of the settlers to have a representative on the Legco. Girouard was not making a good impression in London or with the colonial administration in place in the protectorate. He appeared as a sad little fool. Moreover, his opinions and actions favoring the settlers in this case laid the foundation for the Indian question, which caused such great controversy later in Kenya's history.

What did Girouard get for his troubles on behalf of the settlers? He got nothing, up to this point. Yet he continued to go out on a limb for them. Another example of this was Girouard's favoring the settlers' point of view in his handling of the CO's desired

350 Churchill, My African Journey, 64-65. 
changes in the EAP's land laws. That was not all the governor tried to do for the colonists. When he was confronted with the issue of labor provision and taxation in the protectorate, he also tried to formulate policies that would benefit the colonists. The dragging issues of the land bill implementation, sufficient labor supply and taxation.

The new governor was concerned about the rather "moribund" state of the EAP's economy. He believed that most of the settlers were "discontented and bitter" because the economy was not growing and was failing to provide them with opportunities for development. Land policy and the terms of leases were important elements in this. In a telegram to the Secretary of State in early 1910, Girouard reported on the revision of the Crown Lands Ordinance that had been suspended pending his input. The new governor took up Delamere's position in opposing the writing in of rent revision after thirty-three years. He agreed with Delamere that the settlers would, "very probably" get some form of self-government by then, thus making the provision nothing but an "unnecessary aggravation." He reasoned that it would most likely be undone. ${ }^{351}$ In this Girouard was compliant with the wishes of Delamere and the large landholders. Even as early as November of 1909, Girouard urged that the size of any holding was of no importance. 352 It only mattered that the land was being developed. In our contemporary parlance, this was tantamount to throwing the small farmers "under the bus," most of whom were people of color who would be soon find themselves alienated from their land and homes all to make room for the expansive development plans of the white settler class, whose

${ }^{351}$ Girouard to Crewe, 17 February 1910, CO. 533/71.

$35^{2}$ Girouard to Crewe, telegram, 12 November 1909, C.O. 533/63 and dispatch, 23 September 1909, CO. $533 / 63$ 
dreams included turning the EAP into a "white man's country," like their beloved South Africa.

So what did Girouard demand from the settlers for this huge concession? Once again, no demands were made. As it was during Eliot's administration, Girouard had his own way of formulating policies he found suitable for the protectorate. He also interpreted the orders of the $\mathrm{CO}$ in his own way. For instance, he failed to implement the land ordinance the $\mathrm{CO}$ had long desired. This was a dragging issue due to the fact that the late governor Sadler failed to get the land ordinance amended to meet the desires of Lord Elgin and the CO.

With the governorship of Girouard, still no progress was made on the matter. In part, as Sorrenson underlined, this was due to the fact that "Crewe had agreed to withhold a decision on the version passed by the Legco in 1909 until Girouard had examined the situation on the spot." 353 With time elapsing and the problem over the land bill unsolved, the Europeans settlers were busy with their efforts in trying to block the implementation of the revised ordinance desired by London. Girouard knew that the colonists did not want any implementation of the land bill. He approached the CO, pointing out that: "there was a very strong feeling ... in the country entirely averse to any revision of rentals within the period of a 99 years lease." 354 It is to say here that the general mood and discontent in the protectorate were the manifestation of the settlers' frustrations who believed that they were being hampered by the CO. Any effort made to prevent dummying or an introduction of land tax was not desired by the settlers. They considered land accumulation, as normal phenomena in this new protectorate that they

353 Sorrenson, Origins, 120.

354 Ibid. 
believed would become a self-governing territory in a very near future. Girouard appeared to be so in tune with the settlers that he did not even need to ask them what they needed. He wanted the land bill to remain the same and that translated to the benefit of the expatriates pushing for cheap land.

Reactions in the $\mathrm{CO}$ emerged when the governor formally asked not to modify the land bill. Butler, the private secretary of S of S Lewis Harcourt, noticed that the governor was leaning more and more towards the settlers' camp. Butler affirmed that the governor was "prepared to throw over, in deference to the wishes of the White Settlers, the conditions imposed by the Secretary of State." 355 The governor was like a magic goose that could be counted on to continually lay golden eggs for the influential newcomers. The fact that settlers, with Girouard by their side, were successful in blocking the land bill marked a significant turning point in Kenya political history. With the unsolved land issue in the EAP, a major problem was created without a solution and sooner or later it would resurface in the region as long as the settlers were present asking for privileges while aspiring for political power. Their longtime cry was "no taxation without representation" alluding that the Africans must be taxed and forced to work.

The necessity of implementing the land bill was not the only issue facing Girouard. The European settlers had long been concerned with securing an adequate supply of labor. They also believed that measures needed to be put in place to effectively monitor and tax the Africans. In the EAP, no colonial administration enjoyed much success in dealing with these issues, deemed so important by the European settlers.

355 Minute by Butler, on Girouard to Crewe, 17 February 1910, CO. 533/71. 
Girouard also inherited labor troubles from Sadler's administration; and this was largely due to the settlers' constant demands for the cheap provision of men ready to work.

Land ownership, labor supply and taxation were issues of concern for the colonists because they never stopped advocating tax increases to manipulate the Africans into working for meager wages. The newcomers also expected the Africans' holding of land to be limited so that they could benefit from the situation by getting a more readily available labor supply. The idea was that with Africans confined in small groups in alienated areas, a permanent labor supply would be secured. The colonists feared the possibility of the creation of reserves where the Africans could remain far away on their own, dodging taxes and working for themselves. The Africans, whom the settlers thought of as "lazy children who must work harder if they wanted to get out of poverty," were not free to choose their own destiny. Keeping Africans in reserves or having them living in small groups for the sake of fulfilling the settlers' need for labor was altogether wrong. There was no policy suitable for the Africans as long as the European colonists were lobbying for their interests in the region. With the European settlers being able to wine and dine the governor, their political influence had its effect in shaping the policies of the EAP. One of their best tactics was to effectively manipulate the governor by befriending and winning his confidence. Consequently, the political influence of the colonists had its effects on the governor's theory of solving the pending labor crisis. As Clayton and Savage described it:

...he wished to follow the South African pattern of a Native Affairs Department actively 'encouraging' men to work for settlers, thinking in terms of a 'Recruitment of Native Labour Ordinance' and a 'Masters Union' of employers for recruiting. The Colonial Office offered no support for this latter proposal and it found little favour locally. Nevertheless Girouard personally urged chiefs to recruit labour, and his administrative officers returned to the old practices of 'encouragement' with few questions asked, even giving the chiefs quotas of men which their area were to produce. Girouard's views on land, taxation and policy in the reserves also coincided with the views of the more moderate of the settlers and served their interests. His work included a general improvement in the efficiency of the administration, measures to strengthen the authority of the chiefs, 
instructions to administrative officers on their duties which for example included a requirement that provincial commissioners were to include notes on where labour might be obtained in their handing-over reports, and increases in the number of these officers in the more heavily populated reserve areas to tax and perhaps 'encourage'; these actions all greatly helped the settler and his labour supply. 356

Looking at the other side of the coin, one comes to the realization that having the Africans do the work to develop the protectorate and pay the taxes only added to their misery; and that was a dangerous social situation in the making because the day would eventually arrive when the mistreated, underpaid, and landless workers would rise up and strike blows to secure their freedom. Keeping the Africans down in favor of the European settlers was not something desired by the CO, but the decisions being made always benefited the settlers. The colonists in the EAP would not even be satisfied with the fact that the Africans were required to pay taxes or face penalty of imprisonment. A hut and poll tax ordinance was introduced in the Legco in 1909. A poll tax was introduced in 1910 for adult men who had not paid hut tax. For adult African men, this tax was mandatory. The tax was 3 rupees payable in cash or in kind.357 In March 1911, Delamere demanded increased freight rates be levied on the unbleached white garment worn by Africans and blankets. 358 That was synonym to a method of indirect taxation coercing the Africans further to work for Europeans. The European settlers who believed in representation without taxation decided earlier in 1909 to join forces and come together politically as a single strong party.

\footnotetext{
356 Anthony Clayton and David C. Savage, Government and Labour in Kenya 1895-1963 (London: Frank Cass, 1974), 40-41.

357 Ibid.

${ }^{358}$ E. A. S., 25 March 1911.
} 
Together as one: The European settlers' Convention of Associations

The settlers for whom Girouard blocked the implementation of the CO's desired changes in the land ordinance were not unified politically. The settlers differed in background, wealth, priorities and political inclination. The smaller landowners of the Pastoralists' Association, largely centered around the region of Nakuru in the highlands, voiced concern over Delamere and some of the more wealthy arrivals and their acquisitions of vast lands along with attendant political influence. Robert Chamberlain, another South African immigrant, had emerged as the spokesman for this group. But realizing their overall small numbers, the pastoralists and other small organizations came to the conclusion that it would be better to work with the likes of Delamere and the CA than to fight them. After all, presenting a unified front to the administration of the EAP as well as the $\mathrm{CO}$ was to be essential if any progress were to be made among the white population. Chamberlain was of the opinion that such a "Confederation" would best serve the interests of all concerned.359 And apparently others in settler leadership were in agreement, for in September 1908 the idea of forming a "Central Committee" was advanced for consideration; and just two years later, a Convention of Associations was convened. As Ross described the process:

Ideas of combined action progressed slowly at first. In 1909 the Colonists' Association, the Pastoralists' Association and the Malindi Coast Planters' Association decided to form a Central Committee of Federated Associations. A split took place in the Colonists' Association because it was becoming too political. Mr. Grogan's scheme of April 1907 for a political federation of all the European associations in the country had not been taken up. He appealed again, on August 3rd, 1910, for an association, not of individuals, but of associations. Lord Delamere had just previously placed his resignation, on some pretext or other, before the Colonists' Association (on July $25^{\text {th }}, 1910$ ), and withdrawn it four days later. On August $4^{\text {th }}$ he again resigned, demanding the adoption of the Convention of Associations. This being conceded, he withdrew this resignation also. No count has been kept of the number of times that Lord Delamere has resigned from various bodies

359 E. A. S., 13 June and 11 July 1908. 
in East Africa. In a circle that was formerly wide, but which is now narrowing, the threat has often sufficed to effect compliance with his wishes. Eight associations and two chambers of commerce were invited to meet for the first Convention on October $3^{\text {rd }}$, 1910. The proposal was then formally put and adopted, and an inaugural dinner was held next month, with Governor Sir Percy Girouard as an invited guest. One Association, the Limoru Farmers, formally revoked its previous non-political character. The others slid into the new activities in which the promoters of this new venture chose to utilize their services. 360

This was the dawn of a new day. From now on, the governor and administration of the EAP would then have to deal more with the representatives of a powerful organization, the Convention of Associations (C of A), rather than with individual settlers. This body was sometimes referred to solely as the "Convention," and at other times as the "Settler's Parliament" or "White Parliament." Dilley maintained that it "exerted an influence far beyond any unofficial organization." 361 By this, she meant that it served to provide a medium for the expression of European settler political opinion. By and large, this $\mathrm{C}$ of $\mathrm{A}$ operated in accordance with the principal that the "squeaky wheel gets the grease." In this, the settlers did not hesitate to employ the tactics of agitation in achieving their objectives. They were so proficient in this political technique that seemingly "spontaneous campaigns" could quickly be assembled and mobilized. Ross, who was present in the EAP during that time, consistently maintained that the convention was so powerful that every governor of the protectorate ended up being subservient to it. The settlers' influence was high to such a degree that Girouard became their envoy to London to defend their cause. The continued settler agitations for legislative representation persisted throughout 1910, so much so that in August of that year the governor made a trip to London where he took hold of the opportunity to discuss this issue with the powers-that-be in the CO. As Girouard proclaimed that he

${ }^{360}$ Ross, Kenya From Within, 171-172.

${ }^{361}$ M. R. Dilley, British Policy in Kenya Colony, (London: Frank Cass \& CO.LTD, 1966), 41. 
was making this trip at the behest of the settlers, 362 the $\mathrm{CO}$ decided to listen carefully to his message and graciously received him. Usually, the governor would find that the $\mathrm{C}$ of A was quite helpful to him in addressing most issues facing the protectorate, except for that of African and Asian labor. On their part, the settlers remained politically active.

In 1910, the chairmanship of the $\mathrm{C}$ of A passed to the hands of the ruthless Grogan and that meant that more settlers' grievances were going to emerge. The first meeting of the $\mathrm{C}$ of A was convened in February 1911. There were 19 delegates from eight regional organizations in attendance. Some of the issues coming before the Convention were the so-called "Colonists' Plot," the Asiatic question, railway management, the construction of a deep water pier, the protectorate's representation at a forthcoming Imperial Conference, a pass law for the Africans, the so-called "Kaffirfarming" question, European educational standards and the matter of a poll tax. But most on the minds of the delegates was their uniform concern with securing greater representation on the Legco; and this is the issue that would persist in settler demands well into the next decade. 363

The settlers, now politically organized to a higher degree than ever before, began to think of themselves more as a "parliament," of sorts, when they assembled for this first meeting of the C of A.364 At this gathering, many of the EAP's officialdom were in attendance, as pressing issues such as the enforcement of the "native pass laws" and the nagging "Asiatic questions" were brought up for panel discussions. 365 Delegations were sent to the governor about the attainment of elected representation, which the settlers

\footnotetext{
${ }^{362}$ Girouard to Crewe, secret, 26 May 1910, C.O. 533/74.

363 E. A. S., 11 February 1911.

364 Bennett, "Settlers and Politics," 283.

365 E. A. S., 4 February 1911.
} 
believed was "almost within a hand's reach." ${ }^{666}$ Girouard was sympathetic with the delegates, but expressed his opinion that the $\mathrm{CO}$ would most likely not do anything to make this happen anytime soon.

However, by this time the $\mathrm{CO}$ realized that London was dealing with another "loose cannon" on the deck of the EAP. Girouard was supposed to be their man in the protectorate, representing the interests of the crown. But here he came to London, pressing the demands of the small but vocal group of settlers, who had now bonded together in a semi-parliamentary type of political organization. Interestingly, as time advanced, the power of the Convention continued to grow. Later governors would come to rely even more heavily on this representative body, whose ranks became filled with colonial officials and heads of various departments who would serve in an advisory capacity in hearing, discussing and putting forth "reasonable views" for both the EAP administration and the $\mathrm{CO}$ to dutifully consider. But to say that the Convention was truly reflective of the "official world" would not be accurate, for some of its most vaunted members were actually appointed by the crown to be there as representatives of the EAP's vast African population.

Clearly, the $\mathrm{C}$ of A membership was very effective in generating propaganda to advocate for the cause of the settlers as well as rally against those officials who may have worked against their interests. Ross referred to the $\mathrm{C}$ of A propaganda apparatus as the protectorate's "Big Noise.” Wrote Ross, "The Convention was in no way representative of the official world, nor of the vast African population for which some of the official members stood as representatives. It shows to what an extent the mind even of a keen

366 Ibid. 
observer, when new to the Colony, could be obsessed by the importance of one noisy political group.”367 Clearly then, the propaganda machine only went into gear when it operated in the interest of the small amount of white colonists in the EAP. Heaven forbid that it should have anything positive to say advancing the interests of the Africans or Asians.

Without a doubt, Girouard was nothing like anyone in the $\mathrm{CO}$ had even vaguely imagined. He was acting without authority, and doing more than any other administrator to represent the settlers' interests over every other subject of the crown within the territory of the EAP. ${ }^{368}$ This way of favoring the European settlers deliberately awakened the Indian's conscience and they finally expressed themselves.

Indians in the EAP, deprived of representation in the Legco since September 1911, put forward demands for an Indian to be a member of the council. In early April 1912, moreover, the Mombasa Indian Association sent a petition to the governor protesting against the new non-native poll tax. The major basis for their protest was as there was no Indian member of the Legco, the measure was equivalent to taxation without representation. In forwarding the petition to London, acting governor Bowring maintained that the absence of an Indian member was 'not because we refuse the principle of Indian representation but because no suitable member of the British Indian community is available.'369

Such was the attitude of the CS vis a vis the question of Indian representation.

Nevertheless, the Indians later organized themselves like the European settlers to better channel their grievances. They later went on to form the East African Indian National Congress (EAINC).370 As regard to the Africans, they had no political representation yet and they were subject to all kind of abuse under Girouard's watch.

\footnotetext{
367 Ross, Kenya from within, 173.

368 Girouard to Crewe, telegram, 16 Aug. 1910, CO. 533/76.

369 Robert Maxon, Struggle for Kenya (London: Associated University Presses, 1993), 52.

${ }^{370}$ See Robert G. Gregory, India and East Africa (Oxford: Clarendon Press, 1970), 93-94.
} 
Death of an African and the case of a flagrant miscarriage of justice

Just how far Girouard would go in advancing settler interests over not just those of Indians but those of the crown was more than aptly demonstrated in his handling of the so-called "Cole case," an action that was construed as a severe violation of the human rights that should have been afforded all Africans in the protectorate. The incident that reflected poorly on the Girouard governorship was the 31 May 1911 trial of the white settler, Galbraith Cole, charged with murdering an African that he suspected of robbing some of his sheep, and further complicating the matter by not reporting it to the police. Turning a blind eye to a crime as severe as the murder of an African in the protectorate was not going to pass unnoticed at the CO. Nevertheless, the governor tried to minimize the impact of the crime just to protect Cole.

While, the French Canadian engineer ruled the rails of the British East Africa Protectorate, a massive train wreck was in a making. Girouard played the role of supervisor and administrator of the EAP, and that led to his downfall. The governor did not understand that the $\mathrm{CO}$ was his employer. In the Cole case, Girouard went on too far in not wanting to be clear with the CO. Why didn't Girouard play fair and accept his role? He wanted to please the settlers no matter the price. It was for this reason that Girouard had earlier decided to cater to the big men from the colonists' camp. Regarding the murder case, it was important to point out that the settler involved here had influence. Galbraith Cole was not just an ordinary settler, at least in the sense of being cut from the traditional South African cloth of the vast majority of whites finding their way into the EAP. He was the son of the Earl of Enniskillen and the brother-in-law of Lord Delamere, himself the wealthiest and most influential of the settlers and the anointed of the newly emergent $\mathrm{C}$ of $\mathrm{A}$. Reflective of his high status among the settler 
class, Cole owned and supervised the operations of a large ranch estate near Lake Elementeita.371

The court had convened in the heart of the white highlands, Nakuru district; and at the trial, which lasted but the space of a couple of hours during one afternoon, Cole brazenly admitted that he had shot a black man that he suspected of stealing some of his sheep. And while the judge did admonish the jury of nine white men to confine themselves to the evidence at hand pertinent to the charge of murder, they nevertheless took but five minutes to reach a decision of acquittal for Cole. 372 And while the jury's decision sparked outrage throughout the whole of East Africa, it took Girouard one entire week before he even bothered to inform the $\mathrm{CO}$ by telegram of the incident.

While Girouard did mention that it might be possible to appeal the verdict, he went on to state that he, upon receipt of legal counsel, would strongly advise against taking such an action. It was better to just ignore the incident, hoping that the memory of it among the Africans and others incensed by it in East Africa would quickly fade. Girouard actually sided with the settlers in this case, letting the CO know, in his telegram, that "the crime is due to the prevalence of unrestrained stock theft." 373 In other words, the life of a black man in East Africa counted for less than that of a sheep.

Girouard was already up the proverbial creek without a paddle, for the East Africa Department (EAD) had already garnered some details of the Cole case through pre-trial press reports of the preliminary inquiry, held five days before the actual trial

\footnotetext{
${ }^{371}$ See Eleanor Cole, Random Recollections of a Pioneer Settler (Woodbridge, Suffolk: Baron Publishers, 1975), 35 .

372 Proceedings Crown vs Gailbraith Lowery Egerton Cole, criminal case 94 of 1911, enclosure in Girouard to Harcourt, confidential, 24 June 1911, CO 533/88. See also Robert M. Maxon, "Judgement on a Colonial Governor: Sir Percy Girouard in Kenya,” Transafrican Journal of History 18 (1989): 93-96. 373 Girouard to Harcourt, telegram, 7 June 1911, CO 533/88.
} 
took place. The head of the EAD, H. J. Read, was outraged by Girouard's apparent low prioritization of this case. Read noted that, "It seems to me that murder is murder and that it is out of the question to let the matter slide in the easy manner he [Sir P. Girouard] appears to contemplate.”374

Others in the $\mathrm{CO}$ were in agreement with Read. Sir George Fiddes, the assistant under-secretary of state, felt that "Girouard had a plain duty to appeal such a particularly atrocious case." To correct this situation, Read wanted the CO to reply with a strong telegram to Girouard. And even the Secretary of State Lewis Harcourt jumped in, dashing off a telegram to Girouard on 12 June 1911 that made it more than clear that "a callous and unjustifiable murder" had transpired in the EAP and that a "gross miscarriage of justice" 375 had been allowed to occur.

And that is what happened. The CO's telegram urged Girouard to "appeal from the order for acquittal if you are advised that it is possible," ${ }^{776}$ regardless of whether he felt that it would result in a more favorable decision for the crown. Of course, the British Empire must always be seen as standing on the side of justice for all its subjects.

Nevertheless, one week later Girouard, in replying to the telegram, stated that such an appeal was legally impossible. For the remainder of the month and most of the next month, Girouard did not hear anything more from Harcourt or anyone else at the CO. He was beginning to worry. He knew that the case had stirred up a hornet's nest at the $\mathrm{CO}$ and he was not hearing anything more. He knew that the $\mathrm{CO}$ wanted some corrective action and that it was up to him to provide something. If Girouard did not

\footnotetext{
374 Minute by Read, 9 June 1911,on Ibid

375 Minute by Fiddes, 9 June 1911 and Harcourt. 11 June 1911, on Ibid. Harcourt to Girouard, telegram, 12 June 1911, CO 533/88.

${ }^{376}$ Harcourt to Girouard, telegram, 12 June 1911, CO 533/88.
} 
throw the dog a bone pretty soon, he was going to get his legs gnawed off. That per se would not have been pleasant for Sir Percy Girouard.

And so it was that at the end of June the governor sent an official dispatch and private letter to London providing further details about the case. This dispatch also included a thorough copy of the Nakuru district court proceedings. Unfortunately, Girouard could not help but including a reference to the crime as being "due to the prevalence of unchecked stock thefts." 377 Apparently, he learned nothing from the receipt of prior communiqués that this was considered by the $\mathrm{CO}$ as nothing but a lame excuse for the unjust murder perpetuated by Cole and sustained by the exclusively white settler jury. Nevertheless, in his private letter of 25 June, Girouard did recommend to Secretary of State Harcourt that within the EAP there be a "suspension of trial by jury" and that the "deportation of Mr. Cole" be facilitated. He also asked Harcourt for some guidance on this matter, insofar as he was "unsure of my exact rights and your possible orders in the case." 378

The hornets were now abuzz in the EAD of the CO. H. F. Batterbee was befuddled as to why the defense counsel "did not attempt to set up any defense and evidently relied upon the jury to acquit simply because he was a white man." And the permanent under-secretary Sir John Anderson stridently urged that Girouard's second recommendation for the deportation of Cole be expeditiously carried out in accordance with the provisions of Section 25.1 of the 1902 East Africa Order-in-Council, insofar as Cole was "conducting himself so as to be dangerous to peace, order and good government in East Africa." To make this happen, Anderson pointed out that all that

377 Girouard to Harcourt, confidential, 24 June 1911, CO 533/88.

${ }^{378}$ Girouard to Harcourt, private, 25 June 1911, CO 533/88. 
Governor Girouard needed to do was sign a single affidavit attesting to Cole's despicable actions, thereby ordering his deportation. The Secretary of State was in total agreement with Anderson and noted that it was "a very horrible case.... Cole must be deported."379 Therefore, on the very same day he received Anderson's recommendation, 28 July 1911, Harcourt send the following telegram to Nairobi: "On reading papers in the Cole case, have come to the conclusion that he must be departed under Section 25.1 of Order-inCouncil. If you have any observations to make, telegraph them at once as I wish to direct deportation immediately."380

What was it about the word "immediately" that Girouard failed to understand? It took him until the $10^{\text {th }}$ of August, after many telegraphic promptings at that, to finally respond to Harcourt; and his response was totally unsatisfactory when it was received at the CO. Harcourt and the others at the $\mathrm{CO}$ were in a state of shock. Girouard had conducted an end-run around them, consulting various judges in the High Court and the Executive Council instead of immediately carrying out the deportation order. As the judges informed him that an individual acquitted could not be deported, Girouard deemed it sufficient to close the case. However, as the CO saw it, Girouard did not need to consult any judges on a case that might someday appear before them, as all they could do is offer up an opinion, and not a legal binding decision. Girouard, they believed, was duty-bound to carry out their directive per Section 25.1 of the statute and deport Cole from the EAP forthwith. 381

\footnotetext{
379 Minute by Anderson, 27 July 1911, and minute by Harcourt, 28 July 1911, on Girouard to Harcourt, confidential, 24 June 1911, CO 533/88.

${ }^{380}$ Harcourt to Girouard, telegram, 28 July 1911, CO 533/88.

${ }^{381}$ Harcourt to Girouard, telegram, 10 August 1911, CO 533/89.
} 
Concerning this failure to comply with orders on the part of Girouard, the CO had quickly responded, duly informing the governor that he had entirely misunderstood the reason for the deportation. Concerning this matter, the $\mathrm{CO}$ observed that the only connection with the trial was that evidence there established that Cole "is conducting himself so as to be dangerous to peace and good order whose continued presence in the protectorate may provide reprisals by natives.” The CO legal advisors held that no appeal could be made against a deportation order under section 25.1 of the 1902 orderin-council. Thus Girouard was ordered "to undertake the necessary steps to effect the deportation." 382

On 22 August, Girouard telegraphed the CO, still indicating his reluctance to carry out the deportation order unless law officers of the crown in London would make a determination that it was a legal action. Harcourt, of course, was not at all happy with Girouard's delaying tactics. He sent a telegram back to the governor stating that he was not going to refer the matter to legal advisors in London and that Girouard should not further resist in issuing the deportation warrant. 383

The governor, however, still remained obstinate. On 5 September 1911, he telegraphed London with word that he had once again consulted his Executive Council and that he was going to issue the deportation order, but in protest, and only under orders from London. He then sent a convoluted critique of the interpretation of Section 25.1 as previously provided by the $\mathrm{CO} .384$

Everyone at the $\mathrm{CO}$ was aghast at the nerve of Girourd in defying specific instructions. Since when has the governor of a protectorate acted in such defiance?

${ }^{382}$ Ibid. For further detail see Sara, "Rush to Failure," 314-25.

383 Harcourt to Girouard, telegram, 29 August 1911, CO 533/89.

384 Girouard to Harcourt, telegram, 5 September 1911, CO 533/90. 
Read noted that Girouard was clearly attempting to "divest himself of all responsibility in the matter;" and that was something that simply would not do. Harcourt, for his part, consulted with legal counsel, and immediately issued a strong telegram urging the governor to comply with the provisions of the 1902 order exactly. The Secretary of State also reiterated Read's concerns about the governor divesting himself of the responsibility of carrying out instructions issued by his office and noted that, "I regret that throughout this case I have failed to receive from you the cooperation to which I consider myself entitled." 385

While Girouard eventually carried out the order, Harcourt could not help but lament the governor's reluctance in following through with Cole's deportation. After the dust of the Cole case had settled, Harcourt personally rebuked Girouard: "So far as lending me ready assistance, you continued to raise difficulties which appeared to me to be adequately covered by the instructions and opinions already sent to you." 386 Harcourt realized that the incompetence and unwillingness of the governor to obey his orders were clear proof that Girouard was not the right man to run the protectorate. He was an embarrassment for the $\mathrm{CO}$ because he blatantly favored the colonists at all cost. In fact, the period of the Cole's murder case turmoil that kept the $\mathrm{CO}$ officials on edge was not the only time Girouard would risk his career and reputation to protect the settlers. The Europeans settlers who always wanted cheap land and more living space for potential relatives, who might join them in settling permanently in the region, were directly the benefactors of Girouard's decision to relocate the Maasai. The settlers' political influence greatly influenced the governor's daring policy formulation. Girouard went on

\footnotetext{
385 Harcourt to Girouard, telegram, 9 September 1911, CO 533/90.

386 Harcourt to Girouard, private, 24 October 2011, CO 533/90.
} 
to deliberately move the Maasai dispossessing them of their land for the benefit of the colonists. This was déjà -vu all over again because the first Maasai move took place in 1904 under Stewart administration.

The second Maasai move: Stirring up a hornet's nest

The second Maasai move was a clear example of the governor's deliberate and unfair policy formulation in favor of European settlers, as in the Cole case. If Girouard had looked at the history of the first Maasai move, he would not have engaged in negotiations and new tactics to again displace the pastoralists. Creating a new reserve was synonymous to a clear violation of the Maasai's rights, a disruption of their long traditions and way of life. You can call this the second Maasai predicament. Commissioner Stewart, who witnessed and slightly participated in the negotiations that sanctioned the first displacement of the Maasai, warned about the danger of having the settlers in the region demanding more land.

The initiative of moving the Maasai in 1904 was problematic. The issue dragged over from Eliot's administration to Stewart's brief tenure. Stewart then made a prophetic prediction and, as narrated by Ross, stated the following: "After Masai stock had grazed and improved the rough land on Laikipia, to which they were going, settlers would be certain to cast envious eyes upon it as they had already done on the Rift Valley, and he had therefore inserted a phrase in the Agreement of August 1904 that would obviate further trouble. It was the 'settlement now arrived at shall be enduring so long the Masai as a race shall exist, and that Europeans or other settlers shall not be allowed 
to take up land in the Settlements."' 387 The agreement fell into oblivion, and for a second time in less than seven years the pastoralists were being forced to move again. It was clear that moving the pastoralists was going to directly benefit the European settlers.

One might speculate that Girouard's falling out with the $\mathrm{CO}$ on this issue had less to do with his moving of the Maasai out of the area than with his promise of their vacated land on the Laikipia plateau to the white settlers. Girouard, on 7 October 1911, in replying to a telegram sent to him by Harcourt on 5 October 1911, assured the Secretary of State that no land rights of former Maasai lands had been given or promised. This was good enough for Harcourt, who then advised the House of Commons in mid-April 1912 that, "no alloctions of land occupied by the Northern Masai had yet been made." 388

But much to the dismay of the Secretary of State, it appears that such promises were made. According to the Provincial Commissioner C. R. W. Lane, farms had been promised to settlers as early as April 1910, to be carved out of Maasai lands at Laikipia. But this was not actually confirmed to Harcourt by Girouard until he was on home leave to London in May 1912. The governor was at a complete loss in reconciling his denials of 7 October 1911 with what he was relating to Harcourt in this 8 May 1912 interview. 389

As in the Cole case, Girouard was not being truthful with the CO. The Maasai eventually contracted European attorneys to help them file suit for the return of their appropriated lands; but the Secretary of State down to the lowest functionary of the $\mathrm{EAD}$ at the $\mathrm{CO}$ was thoroughly embarrassed by the affair.

\footnotetext{
387 Ross, Kenya From Within, 135. For a full account of Girouard's actions see Sara, "Rush to Failure," 292-308.

388 Parl. Deb. , (Commons), $5^{\text {th }}$ Ser., 37 (1912): 499; and Harcourt to Belfield, 21 December 1912, CO $533 / 115$.

389 See Mungeam, British Rule, 267.
} 
After Girouard's forced resignation from the colonial service in July 1912, his successor as governor, Sir Henry Belfield, would of necessity be required to spend about a third of his time refusing to recognize promises previously made to the settlers during the prior administration. One $\mathrm{CO}$ official, six years after the tenure of Girouard, noted that "there is nothing in his [Girouard's] record in East Africa to show that his efforts would be directed to the permanent welfare of the country rather than to the expediency of the moment and his own popularity." 390 Girouard was captured by the colonists' political machine and as long that he was going to favor them by economically suffocating the Africans and Indians, more struggle for a clear plan of economic was in the horizon.

The CO, however, did realize that some of the promises made to the settlers would have to be kept, even if at least partially, to preserve the integrity of the crown. Harcourt later conceded that this would apply only to any contacts entered into by Girouard on the part of the EAP with the settlers during the year of 1910.391 Girouard's eastern express locomotive that was carrying the most extreme and boldest European political animals in the EAP finally crashed. His administration was a disaster worse than Eliot's chaotic tenure as commissioner of the most troublesome British possession in Africa.

\section{The demise of the European settlers' ally: A fait accompli}

Girouard was highly regarded by the $\mathrm{CO}$, which expected him to hit the ground running. With his appointment, the $\mathrm{CO}$ wanted to foster peace and development throughout the protectorate. The main concern of the $\mathrm{CO}$ was to make sure that

\footnotetext{
390 Memo by Bottomley, 7 March 1918, CO 533/193.

${ }^{391}$ Harcourt to Belfield, 21 December 1912, CO 533/115.
} 
Africans were not left behind, all the while generating profits for the British Empire. In the EAP, Girouard hit the ground hard and crashed. And so it was that Girouard's star fell from the heavens like a blazing comet. His poor handling of both the Maasai move and the Cole case demonstrated his unparalleled ability to treat the CO personnel like mushrooms, always keeping them in the dark and feeding them manure. Both issues raised concerns about the validity of British justice in the EAP. Furthermore, all of Girouard's policies were sympathetic to the settlers and gained nothing for the empire or its interests in the area.

Confident that they had Girouard on their side, the settlers through their C of A went on to demand elective representation in the Legco in November of 1911. To that demand, Girouard gave an astonishing answer. He explicitly wrote the following: “A petition was presented to me for transmission to the Secretary of State praying for the application of the elective principle for the unofficial members of the Legco. This was duly forwarded, but I could not see my way to recommend the proposal at present."392

The governor, for the first time in his mandate, rebuked the colonists' demand for elective representation. Perhaps Girouard by now realized that he did not gain anything from his liaisons with the colonists. He appeared like a sad fool because he painted himself into a corner and had to wait until the paint dried before he could get out of the room. The response of Girouard clearly contradicted the remarks he made in his first report about the political state of the protectorate. When he took over the governorship of this trouble-ridden British dependency, he criticized some of the officials in the Legco, finding them weak and passive. He then wanted to see more unofficial members

392 Girouard to Harcourt, 18 February 1912, CO 533/102. 
from the colonists' camp to have seats and participate in the political debate of the Legco.393

Girouard now flip-flopped, making a 360-degree about face. Paying attention to the last line he wrote concerning the petition: "I could not see my way to recommend the proposal at present," one could easily surmise that he was just waiting for the political cloud covering the troublesome protectorate to clear. For by attesting that there was nothing he could do at that present time, he left the political door open for the settlers. What he wrote meant that if not now, maybe or surely later, the colonists' petition will be able to resurface. Knowing the nature and character of the settlers, coupled with their traditional season for trouble from February to April, it would be just a matter of time before the $\mathrm{CO}$ would be hearing from them again, knocking on their door with the same tired plea. The colonists' persistence in pushing their agenda was pointed out by Dilley, who remarked that:

From the first Europeans have looked forward to the time when they would have full self-government, or responsible government, for themselves. Always, even while urging a particular change, such as appointed unofficial on a legislative council in 1905 or elected representatives in 1913, they have insisted that they were asking for a moderate change in no way endangering the control of the Colonial Office over the population of the Colony. However, they have always had the ultimate goal in view. As soon as one gain has been made, sometimes before it has been completed, demands have begun for additional reforms. While they were waiting for elective representation, responsible opinion was demanding changes in Colonial Office practice granting more power to the Legislative Council, including the elected representatives. Lord Delamere, when the terms of the legislation were being discussed, in his first election manifesto said: 'The chief duty of your representative is, I am sure, to help forward any policy which by increasing the population and wealth of the country brings nearer self-government.'394

The settlers' strong belief in the possibilities of running the protectorate by themselves in the near future emboldened them to act like "pure political animals", on and off the EAP's political stage. They wanted the protectorate to be left to them.

393 Bennett, "Settlers and Politics in Kenya," 281.

394 Dilley, British Policy, 55. 
Such an agenda was pushed in a variety of ways during Girouard's term. To the settlers, success meant creating a white man's country; and the likes of Grogan and Delamere carried themselves as if they had already established it. Grogan's flogging of Africans and the murder of an African by Galbraith Cole were clear indications of the violations of Africans rights. These cases are definitive examples of how most of the colonists behaved in the EAP. The colonists thought that they were above the law and believed that they could act with impunity, meaning that no punishment whatsoever could be levied against them, no matter how grave the crime they committed. These two cases, although they occurred during two different administrations, with the former during Sadler's tenure and the latter under Girouard's watch, brought the debate of the true meaning of crime and the application of punishment in the EAP. Could the European settlers get away with crime without enduring the reaction of the $\mathrm{CO}$ officials or the humanitarians in England? Nevertheless, in the EAP when justice was served to the colonists, it never matched the gravity of the crime. Impunity in the early political days of the protectorate left a blue-print in the history of crime and punishment in Kenya. More than a century after settlers' violations of Africans' rights, the president of Kenya, Uhuru Kenyatta, found himself before the international criminal tribunal having to respond to allegations of masterminding human rights violations and murder against ordinary Africans who simply stood for their rights.

In the case of governor Girouard, who himself believed that unfair political formulation benefiting the settlers was going to remain without consequences, it was this kind of attitude that led to his downfall. Violations of Africans or Indians' rights, whether physical or discriminatory in the EAP, could not continue to be the news that the $\mathrm{CO}$ was receiving from the protectorate because anything leading to a political 
embarrassment was not desired at Whitehall. Political embarrassment was a sour pill to swallow because it could derail the political career of any official serving the British Empire in the EAP.

Girouard, an appointed official of the British Empire, embarked on a fruitless quest to crown himself the "king of the settlers," without even taking into account that their acclamations were kept for the likes of Delamere and Grogan. Girouard, now considered a pariah in the colonial service, hobbled on until he finally saw the light and resigned in July 1912. Everyone in the CO, and especially the EAD, let loose with a huge sigh of relief.

$\underline{\text { Conclusion }}$

Governor Girouard had done his best to safeguard the interests of the European settlers throughout his tenure in the protectorate. The colonists grew stronger politically and were pleased with the fact that the governor was their man. By the time that Girouard resigned, three years after he took over, there was no doubt that the EAP was not being administrated along the lines of British West Africa. The man that the $\mathrm{CO}$ regarded as the right choice to bring peace and steady economic development in this troublesome dependency did not fully count upon the contributions of the East African people in the fulfillment of his mission. In the EAP, pro-European settlers policies replaced pro-African policies such as were implemented in West Africa. In the EAP, the presence of the European settlers changed the sociopolitical dynamic of the region due the fact that it led to the economic disenfranchisement of the Africans, as well as the Indians who also considered the region as their new home. Their demands to be provided with cheap land, a plentiful labor supply and more political power shifted the 
balance of the priorities of the governor. His policy formulation directly benefited the colonists. Ross elaborates on the "star power" Girouard exercised among the colonists:

With the European community Girouard was able to claim a considerable measure of success. Apart from his championing of settler interests over the Masai move there had been a decline in the settler spirit of factious opposition to Government, and greater co-operation between Government departments and the European population had been achieved. The reason for this was not hard to see. The settlers had found themselves being led by a Governor who appreciated many of their difficulties, and who was prepared to take active steps to improve their lot. 395

Nevertheless siding with the influential settlers to the point of depriving the Africans and other groups present in the protectorate of their basic human rights was not something desired by the $\mathrm{CO}$. The office took action in removing undesirable settlers like Cole from the protectorate and sacked Girouard; but the problems of the protectorate were far from over. What kept the European settlers relatively quiet during Girouard's tenure was the fact that Girouard himself made numerous promises to them. Of course, to the colonists these promises were regarded as a contract that the successive administration would be obligated to follow through with. Girouard's tenure put the $\mathrm{CO}$ in a bind. The passage of years would not diminish the CO's low estimation of Girouard and his tendency to promise what he knew that neither he nor the empire would be able to satisfy. A private Secretary at the EAD, W.C. Bottomley, later expressed the fallouts from Girouard's administration stating that:

The mark he left on the protectorate at the end of the administration in 1912 was rather one of promise than of performance. His promises in fact were the chief difficulty in the way of his successor and Sir Henry Belfield was continually in a position of having to refuse to recognize alleged promises made to settlers by Sir Percy Girouard.... There is nothing in his [Girouard's] record in East Africa to

395 Ross, Kenya From Within, 271 
show that his efforts would be directed to the permanent welfare of the country rather than the expediency of the moment and his own popularity. 396

It was clear to everyone in London and the protectorate itself that the policies, which

Girouard put in place, were going to cripple the following administration; and that

meant that the struggle to contain the settlers was not at all finished.

396 Memo by Bottomley, 7 March 1918, C.O. 533/193. This memo was written as a rejoinder to a demand from Kenyan settlers that Girouard be sent out as military governor for the rest of the war. See Maxon, Struggle for Kenya, 41-42. 


\section{Chapter 6}

$\underline{\text { Conclusion }}$

The various administrations imposed on the EAP between the period of 1902 and 1912 manifested as a continual struggle between the European colonists' explicit desires for cheap or free labor and land, as well as immediate and disproportionate political representation against the CO's desire for a caretaking and intermediate regime that would ultimately, in the fullness of time, transfer power to the Africans and others of His Majesty's subjects in the region. The CO wanted to see the EAP converted into a self-sustaining and democratically administered Crown Colony, with equal representation for all, much on the same footing as Australia, Canada or New Zealand. Dilley noted that: “This desire to establish a British colony in East Africa had certain Imperial aspects. A white colony loyal to the British Empire would be the most effective way of holding the country. It would assist in the support of the Uganda Railway. There was a certain element of Imperial pride in the establishment of a British colony on the equator, and it was important link in the north-and-south route in Africa. But there was little active encouragement of colonization, as such, by the British authorities; their part came in supporting those colonists who had gone out on their own initiative to settle and develop a new country."397 The European settlers who came to the EAP engaged in politics of imperialism.

The politics of imperialism was a hotly debated subject in the Great Britain of the early twentieth century. Both civil and political freedoms were viewed as mutually dependent. But for the majority of His Majesty's subjects, scattered across a global

397 Dilley, British Policy, 275. 
empire, these freedoms were virtually nonexistent. Perhaps it can be said that some degree of representative government existed in Australia, Canada and New Zealand; but even in these areas considerable population blocs seemed to be disenfranchised from the body politic, i.e. Aboriginals in Australia, Quebecois in Canada and Maori in New Zealand, to name a few. Let us not forget the exploited non-Northern European immigrant labor force in all of these countries. The failure of even these larger British colonies with majority white populations to incorporate these groups did not bode well for any claims of the emergence of any genuine democracy in these places. In those areas under British rule where the whites were vastly outnumbered, the idea that any sort of democratic system was in place was purely laughable. For example, with regard to South Africa, the point of origin for most of the white settlers in the EAP, one political scientist of the day astutely noted that, "In Cape Colony and Natal events testify how feebly the forms and even the spirit of the free British institutions have taken root in States where the great majority of the population were always excluded from political rights. The franchise and the rights it carries remain virtually a white monopoly in socalled self-governing colonies, where the coloured population was, in 1903, to the white as four-to-one and ten-to-one, respectively." 398

In some of the older Crown colonies extant in 1905, there did exist, at least, some representative element in government. Of course, the administration was totally vested in a Crown-appointed governor, who in turn was assisted by a council of his own choosing. Nevertheless, the colonists were afforded the right to elect a portion of the legislative assembly. This system was in place in many of the British Caribbean islands,

398 Hobson, Imperialism,115. 
in addition to the further reaches of Malta, Mauritius and Ceylon. But even in these areas, the representative element never out-numbered the non-elected element. In other words, these colonies' respective legislative assemblies exercised more of an advisory role rather than an authentic legislative function. Hobson elaborated on the political implications of this situation: "Not merely is the elected always dominated in numbers by the non-elected element, but in all cases the veto of the Colonial Office is freely exercised upon measures passed by the assemblies. To this it should be added that in nearly all cases a fairly high property qualification is attached to the franchise, precluding the coloured people from exercising an elective power proportionate to their numbers and their stake in the country." 399 In the EAP, this system of representation was advocated by the $\mathrm{CO}$.

Now it has been demonstrated that the CA comprised no more than 300 members at any time. Most of these members arrived in the EAP from South Africa with big dreams of striking it rich, and in the process converting the protectorate into one of the more prosperous of the Crown colonies; a true "white man's country." In lieu of their small numbers and outrageous demands, and in consideration of the slow democratization taking place in other areas with large colored contingents throughout the Empire, it appears that the association members held an exaggerated view of their own importance in the larger scheme. By acting against the Rudyard Kipling-inspired "White Man's Burden" 400 of extending all manner of education and service to lift the

\footnotetext{
399 Ibid.

400 "The White Man's Burden" was written by Rudyard Kipling in 1899 when the politics of imperialism was a major subject of debate in England. Although it was a poem, Kipling emphasized the necessity of imperial expansion from the part of the United States. He encouraged the United States' involvement in the Philippines and held the belief that civilizing and governing the "lower races" was a good moral cause. Some scholars of imperialism simply argue that the poem was a mockery of the futility of imperial
} 
quality of the colored races and bring them to the light and knowledge of Anglo-Saxon civilization, they were also going against the wishes of the $\mathrm{CO}$. The colonists were out of step with the prevailing attitudes of their day; and as a consequence, their days in the EAP were already numbered. Nevertheless, these European settlers that Churchill described as "political animals" would not accept the reality on the terrain. They decided to put up a fight and stand for their rights, in that instance, they engaged in frequent political agitations which impacted the socio-economic stability of the protectorate. The colonists' political aggressiveness was not hard to detect due to the fact that they had an incommensurable influence upon the imperial government and the local administration. The newcomers' political strategy led to a clear racial division within the protectorate and that caused a problem that the CO did not want to see happening in the region.

The various racial divisions within the protectorate worked against the long-term goals of the $\mathrm{CO}$ and the empire in general. This was expressly noted in the highly vocal European settler camp, many of whose members hailed from nearby South Africa. Despite their meager numbers, the white settlers continually pushed the envelope, generating incessant demands for concessions from London that would work in transforming the protectorate into a so-called "white man's county." For that reason, the ten year period from 1902 to 1912 might best be categorized in what Berman and Lonsdale referred to as the emergence of "storm-tossed relationships of power" that greed, vanity, racism and elitism. 
only served to inhibit the social construction of a viable CS in line with the overall objectives of the British Empire for the region. ${ }^{401}$

This was the main contradiction that needed resolution before the protectorate could begin to advance to the status of a full-fledged colony. The plight of the Kikuyu peoples is most demonstrative in this area, being highly representative of the complex issues dealing with racial tension generated in both the African and European settler communities. The Kikuyu, like most African peoples in the protectorate, came to be viewed in terms of a "tribe" or as children who needed assistance from the civilized colonists of the Empire. This negated, in turn, any further investigation into the interior structures inherent in their society, as well as any rights they may have within it to claim a nation state for themselves based on any true sense of Kikuyu nationalism. In other words, their tribal status relegated them to the paternalistic whims of the CS. 402 The early political history of the protectorate was marked by the case of a majority of people, referring in this instance to the Africans and the Indians, who had no political power. One can call it representation without political power. These two groups were left behind only to pay taxes to their new masters representing the British Empire.

The political isolation of the Africans and Indians was a total contradiction to the way that the European colonists organized themselves. They formed their political parties and many of them thought of themselves as political leaders apt to run their own party. Winston Churchill noticed the acrimonious political atmosphere that prevailed in the EAP during his 1907 visit. The colonists' political aggressiveness was not hard to

\footnotetext{
${ }^{401}$ See Bruce Berman and John Lonsdale, "Coping with the contradictions," in Unhappy Valley: Conflict in Kenya and Africa, Book One, eds. Bruce Berman and John Lonsdale, (London: James Currey, 1979), 5. ${ }_{402}$ John Lonsdale, "The Moral Economy of Mau Mau: Wealth, Poverty and Civic Virtue in Kikuyu Political Thought," in Ibid., 207.
} 
detect due to the fact that their tactics had an incommensurable influence upon the imperial government and the local administration. They were good agitators. The colonists were able to guide their opinion everywhere and with anybody as long as their demands were going to be secured.

The introduction of the Europeans settlers in the protectorate raised many issues of great political significance that the early successive administrations had to deal with under the supervision of Whitehall. The commissioners and later governors sent to the protectorate had to wrestle with complex issues ranging from the adequate definition of land tenure, rent, exclusive rights to the white highlands, labor provision, taxation and the expatriates' perplexing political demands for representation in the Legco. Mungeam noted that: "The biggest test for Government officials in the realm of local organization came with the entry of the European settlers. These newcomers, encouraged in so casual a way by Eliot in 1903, soon threatened to dominate the scene, and increasingly occupied the attention of the officials." 403 From Eliot's administration stretching to Girouard's governorship, the newcomers increasingly gained influence and forged a fortification to defend their interests. They argued and fought to assert that their presence in the protectorate was legitimate and most of the big men "could argue with some justification that they had entered the country at the invitation of the government, and it was the government's responsibility to assist them, at least to the extent of ensuring that they had adequately demarcated land and a sufficient supply of labor."404 The most politically active and influential settlers had the support of Eliot.

403 Mungeam, British Rule, 280. 404 Ibid. 
Powerful men like Delamere, Grogan and other settlers took the lead and started their own political journey to defend the colonists' interests.

The settlers formed their political associations and started to voice their demands. At first, these were divided by personality and type of farming, amongst other things. They wanted large concessions of land with limited government interference, no taxation without representation and application of British law for them only. Far away in London, the authorities recommended to Eliot that he exercise caution in not frustrating the Africans and Indians already living in the region. Nevertheless, Eliot formulated land policies suitable for the settlers who were acquiring cheap properties without enforcing the terms of the 1902 land ordinance as wished by the FO. The highly regarded commissioner resigned mainly because he was promising land to his favorite settlers without London's approval. The FO found a quick replacement and Stewart took over the administration of the protectorate in 1904.

It is significant to note that the replacement of Eliot by Stewart was an important step taken by the FO. One could interpret Eliot's departure as an anticipated resignation because he lost the trust originally vested in him by the FO. Additionally to consider, there was the intervention from the FO not to let the issues related to the proper distribution of land fester. The action taken by the FO about Eliot's insufficient handling of the issue of land was clear. Regulation and moderation were needed. The welleducated commissioner was technically sacked; but no matter from which angle one looks at the commissioner's actions, it was time for the FO and Eliot to part ways. The FO chose to send Stewart in order to serve mainly as a "safety valve." He was instructed not to repeat Eliot's bold policy formulations solely benefiting the European settlers. 
During Stewart's tenure, the European settlers pressed for CO control; they desired a Legco and Crown Colony status. Stewart appointed a land committee to sort out the issue, but influential settlers made their first move and stood in charge of the committee. A pro-settler team led the investigation and presented a one-sided report. The CO was not impressed by the work of the pro-settler land committee and so the issue of an adequate land survey, and land policy, dragged on. Stewart appeared weak; and neither the $\mathrm{CO}$ officials nor the settlers were happy with his bureaucratic nonchalance. The bold European settlers also were politically concerned with their role in the protectorate and went on to present their demands to the CO in 1905. Their hope was to begin the process that would lead them to a self-governing country and that meant obtaining some form of representation on a council. Before Stewart received any response from London to communicate to the settlers, he passed away.

Stewart did not finish his term; but there were clear indications that he was on a collision course with the white settler's political machine. His decision of appointing a pro-settler land committee indicated that he was letting the settlers test the political waters of the protectorate and that marked the beginning of the settlers' direct participation and interference in the EAP's political matters. It was an important political debut for the European settlers and for the political history of the region. The commissioner sent some hungry land grabbers to survey the region; and this was an obvious farce. Stewart sent the fox straight into the hen house. Nevertheless, the land committee team was delighted to carry out the task of surveying land and delivered a report full of pro-settler recommended concessions. The response of the $\mathrm{CO}$ regarding the issues of land and the Europeans settlers' first formal political demands fell in Sadler's hands. He governed the region from 1906 to 1909. 
Under Sadler, the settlers learned that the CO found their petition for some form of representation on a council reasonable; and they celebrated the news because that gave them the right to participate in the internal politics of the region. Not content with just having a seat in the Legco, the expatriates again voiced their motto of "no taxation without representation." In the EAP, the questions of labor supply and taxation became crucial issues because the settlers wanted to be exempt from tax burdens while possessing the best land and obtaining cheap labor. Land, labor and taxation were correlated.

In East Africa, next to owning land, labor is the most important commodity. Without it, land remains unproductive. But because of the climatic conditions prevailing in the region, it was generally agreed that white men could not long endure the manual labor required to work the land properly. Consequently, the African worker was of paramount importance in the development of the settled areas; and the history of white settlement was closely connected with the struggle for an adequate labor supply. Many difficulties between government and settler sprang up over African labor. And most of the general anxiety which prevailed in the colony was caused by concern over this supply. 405 The adequate provision of labor was meant to satisfy the settlers' need to develop their properties. The expatriates refused to work under the hot African sun, preferring to sit under the shade of the verandas built onto the sides of their houses constructed by imported Indian workers. The Africans developed the land; but this white propertied class reaped all the economic benefits. The European settlers also

405 See Dilley, British Policy in Kenya Colony, 213. 
pressed for some relaxed labor rules where Africans should be obedient and forced to work. There was no room for Africans to disobey, complain or quit their jobs.

This was graphically demonstrated in 1907 when reports of the flogging of some Africans at the hand of Grogan emerged. This grave incident was left unpunished because the punishment did not reflect the gravity of the crime. Grogan's flogging of Africans brought on the table the debate of the need to protect the Africans' rights, much as it was intended with the opening of the protectorate. But here the argument was that without the presence of the settlers, one could not argue about the necessity of protecting the very basic human rights of the Africans who only wanted to live in peace in their land. When many Africans lost their lands, some of them had no other option but to work for the newcomers.

The Africans who were flogged by Grogan worked for him. They were at the mercy of their flamboyant master who acted like a plantation owner inflicting pain on his enslaved workers without remorse and thinking that nothing was wrong about correcting workers or servants from the so called "lower races." Grogan acted like an outlaw in the wild EAP by hijacking the law and acting with impunity. Other settlers who also wanted to raise hell for the governor went on to challenge him with the issue of adequate labor supply. Delamere was the ring leader opposing Sadler, whom the majority of settlers apparently thought was not sympathetic to their grievances.

In 1908, when Sadler decided to redefine the labor supply rules so that it would be fair, the European settlers erupted and demonstrated in front of the governor's house and asked him to resign. The settlers wanted to block any new rules that would render difficult the provision of labor. For the expatriates, no rule was the best rule. New land or labor rules were not desired by the settlers. A laissez-faire policy for the exploitation 
of the region meant potential rapid economic development for the big land owners who were very aggressive and most of the time irrationally violent.

Sadler's governorship marked the era of violence, crime and political disturbances perpetuated by the settlers without consequences. The $\mathrm{CO}$ realized that Sadler was having many difficulties running the protectorate and transferred him. The reality was that the settlers wanted a "man on the spot," much as Eliot was, whom they considered their most respected servant. The CO decision to transfer Sadler to the Windward Islands meant that this body was still in political control. Nevertheless, once again, London did not act fast enough in removing him. Indications here were that Whitehall tended to let the problems affecting the administration of the protectorate brew to a boiling point before intervening. Sadler was too easily manipulated by the white settlers and proved to be a weak governor. It was time for the $\mathrm{CO}$ to make a change. Governor Girouard took over after Sadler and was welcomed by the colonists.

Girouard arrived in 1909 with instructions to bring order and efficiency to the running of the EAP administration. The $\mathrm{CO}$ expected him to get things moving and deal firmly with the European settlers. The issue of the implementation of the land legislation and the need to make the protectorate profitable were crucial for the CO. Girouard arrived and immediately began promoting settlers' interests. He showed favoritism for the settlers as he wanted more European input on the Legco, as well as their active participation in running the protectorate. As was the case with Eliot, Girouard also fell under Delamere's influence. For their part, the colonists combined their various political parties and formed the $\mathrm{C}$ of $\mathrm{A}$ in 1910 so as to be politically more relevant, vocal and aggressive. 
With the backing of Girouard they demanded elective representation in the Legco. With Girouard, the second Maasai move also took place, albeit without the consent or knowledge of London authorities. Naturally, this would come back to haunt him and push him out of office. In addition, in 1911 Galbraith Cole, the brother-in-law of Lord Delamere, shot and killed one African whom he merely suspected of stealing one of his sheep. A jury of white men fully acquitted Cole, but much to the consternation of London authorities, who decried that Girouard let Cole get off so easily without even an enforceable deportation order, let alone having him serve even one day of any jail time. There was no justice for the family of the victim. When compared to Commissioner Eliot, one realizes that Girouard assisted the settlers more in their quest for political control.

As Eliot did, Girouard also resigned; and the reason of his departure was very similar to Eliot's case. Catering to the European settlers was a recipe for disaster. And once again, the $\mathrm{CO}$ was not fast enough in removing him. Problems continued to mount with the way he was running the protectorate. The expatriates were pleased with Girouard and felt like they lost their man, and almost for the same reasons Eliot was sacked. Still, the CO was in control of the EAP.

The study of the early political history of the protectorate showed that the stability needed to properly run the region was never achieved. Instead, a pattern was set where a strong man leading a strong political party would always try to dominate the political scene and break the law with utter impunity and without any meaningful consequences being levied against them. Girouard's administration thus left behind the Africans and the Indians. His favoritism to the colonists was so apparent that Indian protests now emerged and were directed against settler dominance. A balancing 
political force was needed to counter the settlers' interference in the internal issues related to the administration of the region. The European settlers were busy. Their political coalition under the umbrella of the $\mathrm{C}$ of $\mathrm{A}$ was a political maneuver that sought to dominate the political scene of the protectorate.

The European settlers were well-organized and politically active. The Europeans expatriates were flexible enough to form a coalition of associations to come under one political umbrella. This was a smooth political move because the unification of all the parties provided them with a solid pedestal where they could have their voice heard loud by the $\mathrm{CO}$ and any man on the spot trying to effectively run the protectorate. With a strong political base, the settlers could pile up demands after demands working on the edification of their dream land. The settlers were the political progenitor of the notion of one strong political party under one vocal and strong leader dominating the political stage. This created a context where a vocal big man had to rise and dominated the political scene.

In their intent of dominating the region, the expatriates did not hesitate to harshly criticize or threaten the serving officials, the commissioner or the governor. They went on to even use violence against the local population. These illegitimate and unjustified tactics from the settlers' camp brought a new dilemma worthy of consideration. White supremacy and the desire to achieve a white man's country meant depriving the Africans and the Indians of rights and fostered a culture of impunity and this conflicted with the ideals of the modern British Empire and British practice. That belief and attitude meant that they were entitled to enjoy their rights as Englishmen at home, but no other group in Kenya could do so. For instance, Grogan's flogging of 
Africans and the murder of an African by Galbraith Cole were clear indications of the violations of Africans rights.

These cases are definitive examples of how most of the colonists behaved in the EAP. The colonists thought that they were above the law and believed that they could act with impunity, meaning that no punishment whatsoever could be levied against them, no matter how grave the crime they committed. These two cases, although they occurred during two different administrations, with the former during Sadler's tenure and the latter under Girouard's watch, brought the debate of the true meaning of crime and the application of punishment in the EAP. Could the European settlers get away with crime without enduring the reaction of the $\mathrm{CO}$ officials or the humanitarians in England? Nevertheless, in the EAP when justice was served to the colonists, it never matched the gravity of the crime. Impunity in the early political days of the protectorate left a blue print in the history of crime and punishment in Kenya. More than a century after settlers' violations of Africans' rights, the actual president of Kenya, Uhuru Kenyatta, found himself before the International Criminal Court (ICC), having to respond to allegations of masterminding human rights violations and murder against ordinary Africans who simply stood for their rights.

Following the Kenyan national election in 2007, discontent manifested as political street agitation, allegedly orchestrated by the Kenyatta faction. This resulted in some violence, extending into 2008, whereby some ordinary citizens lost their lives, being caught up in urban crossfire. Kenyatta fell under suspicion for both instigating the political disturbances and the unfortunate deaths of the innocent bystanders. Of course, while the Kenyan authorities no longer needed to answer to a distant colonial office in far-away London, they still found themselves required to address these issues 
before the ICC. At the beginning of the $2 \mathrm{O}^{\text {th }}$ century, the officials in the protectorate maintained communications with the Colonial Office in London via telegraphic cable and dispatches. It would literally take weeks, however, for the general public to get word of incidents and allegations insofar as the flow of pertinent data regarding cases of violence were being classified, compartmentalized and pigeon holed in the overall bureaucratic imperial structure. But now, more than 100 years later, with an independent Kenya in the age of satellite transmissions and digital communications, time is no longer is a factor favoring the powers-that-be. Rather, important news reaches the attention of the public at the speed of light.

Despite the technological marvels of the age, where evidence of human rights violations comes to the instantaneous attention of the United Nations and the entire world, the legacy of impunity, established in the colonial regimes of the protectorate era, yet persist in contemporary Kenya. While the world received a continuous flow of detrimental information concerning the allegations against Kenyatta, the investigation purposely dragged on back in Kenya, allowing Kenyatta to win the presidency in the 2013 national election. The charges-while serious and substantial-were finally dropped by the ICC in December 2014. And this hearkens back to the Cole murder case that took place under the nose of the Girouard regime, whereby the $\mathrm{CO}$ continually demanded the truth but received nothing but obfuscated correspondence, thus stalling the matter to oblivion.

The authorities in Kenya were successful in defending themselves against charges of political conspiracy in any violations of human rights that may have occurred in Kenya. Six years after the end of the period of political violence in question, it seemed as if there was still no explanation or justice for the families of the victims. The 
dropping of the ICC charges against Kenyatta naturally brought on a political reaction in Kenya, strengthening Kenyatta's grip on power. He has emerged as the "strong man" in Kenya, and even throughout the East Africa region. Looking deeply at Kenya's present political system and its leaders, one has the impression that by tradition the name Kenyatta is deeply rooted in the political history of Kenya and in the heart of many Kenyans. The actual present Kenyatta family member has fervent supporters in the country. For instance, the UN Ambassador from Kenya, Macharia Kamau, in defending his country, stated that, "There is nothing in the history of our country, nothing in the manner in which we have cooperated with the prosecutor of the ICC in general, that should ever be construed as a lack of cooperation without clear determinable evidence being provided." 406

In contrast to the official view, leaders of the opposition saw the entire affair as a "cover-up" of huge proportions. Nicholas Gumbo, the Rarieda MP from Siaya County, asserted that the withdrawal of charges against Kenyatta at the ICC can be attributed to the lack of government cooperation with that august body, and, of course, this is nothing new in the history of Kenya. Said Gumbo, "It is not only about post- election violence, we have historical injustices that have not been addressed to date. Honestly, before we come out and address those, then we are still postponing our problems.” The MP added that, "If the court found the president not guilty, then it was crucial to ensure the people responsible for the 2007-2008 post-election violence are brought to book. If the court has found him not guilty, the question is who was responsible for the violence and crimes against humanity? You cannot depart with the past. We must sort out the

${ }^{406}$ Standard Digital, Nairobi, 12 December 2014. 
injustices because we live in a country where some communities live as squatters in their own country and it is time this is stopped." 407

Nevertheless, in the Nandi community in the North Rift Region of Kenya, the news of Kenyatta's clearing by the ICC against the alleged charges was received with great enthusiasm and excitement. The pro-Kenyatta faction led by Nandi Senator Stephen Sang and Major John Seii went on to even express high confidence that other cases against a couple Kenyans will eventually be withdrawn by the ICC. Sang and Seii were jubilant. Reports from the Standard emerged and stated that:

Nandi Senator Mr. Stephen Sang and Major John Seii, the Emeritus chairman of Kalenjin council of elders said that they were excited and happy with the dropping of charges against President Uhuru. 'I am very excited that the court has reconciled itself with reality that Kenyan cases were not properly investigated and not credible. The remaining cases will crumble down too,' said Sang. The Senator said the ICC cases 'started crumbling from the start after former Minister Henry Kosgey and former Police commissioner Hussein Ali's cases failed to be confirmed and later the dropping of the case against Francis Muthaura'.

'The president is now a free person, citizen and can freely run the country. The other remaining cases are just like two sides of a single coin and will equally come down due to lack of credible evidence and witnesses,' said Sang. ${ }^{408}$

Here again Sang seemed to have not been aware of the testimony of ordinary Kenyan

citizens. After all, there was a case that:

A prosecution witness has disowned evidence he allegedly gave, detailing how he attended two meetings in which Deputy President William Ruto instigated the 2007-2008 post election. In his statement recorded with the Office of the Prosecutor (OTP) in April 2010, the witness claimed to have attended the secret meetings, one at Sirikwa Hotel in Eldoret and the other at Ruto's Sugoi home. In tape -recorded interview, he had claimed that the meeting at Sirikwa was held on September 2, 2007 and was chaired by Ruto, who was then Agriculture Minister.

${ }^{407}$ Standard Digital, Nairobi, 7 December 2014.

${ }^{408}$ Standard Digital, Nairobi, 6 December 2014. 
The witness had claimed that he paid Sh3, ooo to gain entry into the alleged Sirikwa secret meeting. The second meeting, he claimed was held on September 2,2007 but later changed and said it was on November 2,same year.

He had told the prosecution that the meeting was to organise coordinators and attacks in South and Central Rift Valley. He had claimed to have heard all the speeches made at the event. The Prosecution had taken his evidence so seriously and asked him to tell all the details accurately and precisely. And so precise was the evidence that the witness had offer to draw sketches of both Sirikwa meeting venue and Ruto's house. The evidence was then filed before the Pre-Trial Chamber in 2011 and used to confirm the charges against Ruto and journalist Joshua Sang in January 2012.409

Nevertheless, the case lost momentum when the same witness here turned around and said that he could not remember about the details of his testimony. From the above, the Kenyan analyst comes to understand that the political legacy of impunity is the very bridge connecting the colonial regimes to the present situation. Whereas for every action there is an equal or opposite reaction, it should come as no surprise to discover that the other key element in the political legacy of Kenya is that of mass action.

The Europeans settlers were the first to engage in mass action tactics for the promulgation of their rights in the protectorate and that left an enduring legacy in modern days Kenya's politics. Today's political tactics of mass action in Kenya could be considered as an ongoing tradition originating from the European settlers political kit bag. The frequent use of political tactics directed to the local government was even acknowledged by Michael Blundell, a later settler political leader, who clearly stated that: "[Y]ou made a tremendous political row and forced the government to do what you wanted." 410

\footnotetext{
409 Standard Digital, Nairobi, 12 December 2014. ${ }^{410}$ As quoted in R. Maxon, "Independent Kenya's Colonial Legacy," in A History of Independent Kenya: 1963-2013. A Celebration of Kenya's Fiftieth Independence Anniversary, edited by William R. Ochieng', (Kisumu: Lake Publishers and Stationers, 2013), 29.
} 
The political strategies adopted by European politicians in the EAP have exerted a lasting impact on politics in the region, extending to present-day Kenya. One of the most utilized and effective of these political tactics is that of the mass action campaign. For the most part, there was an emergent trend for these campaigns to coalesce around two partisan groups. The first group consists of those who believe that there exists a deep crisis insofar as the spiraling cost of living is concerned and the growing inability of the average Kenyan citizen to keep her or his head above the rising and swirling financial flood. This group manifests a particular disgust with the president and the weak use of his constitutionally granted executive power to guarantee security and promote an overall confidence in the course of the nation's economic development. With respect to this situation, one prominent Kenyan editorialist wrote, "To resolve this problem, nothing less than a national convention of some kind will help pull us out of this mess. To press their point home, the leaders of this group have set 7 July, the storied 'Saba Saba Day,' as the date on which they will commence on a campaign of mass action to compel the government to accept their proposal." 411 The second group argued that while the nation had serious problems that required immediate attention, these could and must be solved only within the context of existing institutions. The second group also contended that the need for national dialogue on these matters is limited, insofar as the power to handle any situation has already been granted to the people's duly-elected representatives. They also believed that any mass mobilizations and subsequent actions would bear little profitability in helping to resolve any of these issues. With respect to the political dichotomy existing between these two factions, the

\footnotetext{
${ }^{411}$ Wycliffe Muga, “The Return of Mass-Action Campaigns,” Weekend Star, Nairobi, Kenya, 12 June 2014.
} 
Weekend Star editorialist wrote "Recent events starting from the massive crowds that turned up at former PM Raila Odinga's homecoming political rally at Uhuru Park remind us that there has been very little reconciliation between those who found themselves on opposing sides in the 2013 General Election.” ${ }^{12}$

The use of mass action as a political tool in contemporary Kenya can be seen as a throwback mechanism reminiscent of the political tactics employed by the settlers from the very foundation of the EAP, more than a century ago. Just as the settlers so long ago discovered that political mass actions can be a powerful weapon in the destabilization and even the overthrow of governments, so too have the current crop of Kenyan politicians found some utilitarianism in playing this card. For example, in the 1990s, the non-violent mass action campaigns led by former cabinet ministers Kenneth Matiba and Charles Rubia demonstrated that this type of political protest is a definitive strategy in undermining a government's credibility and legitimacy. Even after the instigators of these mass actions were detained, the political momentum even picked up its pace. However, in contrasting the political leadership of the settlers with that of the presentday Kenyan politicians, one must keep in mind that the settlers could at any time resort to mass action tactics without fear simply on the basis of their white privileged status, whereas the black Kenyan politicians were at the most detained. Nevertheless, despite the detention of the Kenyan politicians, the effectiveness of their mass action campaigns was not diminished. And hearkening back to the days of the protectorate, one must also consider that the consequences of instigating mass actions on the part of people of color

412 Ibid. 
could have confirmed the fears of the European elites, thereby resulting in severe and perhaps lethal repercussions.

On the relatively recent Kenyan political situation, the editorialist writes, "Even though President Daniel Moi remained in power for another ten years, after the return of multi-party politics, it is this mass action by ordinary Kenyans which put an end to Moi's single party rule and fundamentally changed the Kenyan political landscape.” ${ }^{413}$ In a similar vein, one can see the effectiveness of mass action at work on the part of the white settler class in early $20^{\text {th }}$ century EAP politics. None of the regimes installed in the protectorate by order of the $\mathrm{CO}$ were able to withstand the mass actions instigated by Delamere, Grogan and other leaders among the small but growing and vocal C of A. This was particularly evident in the fall of Sadler, who was seen as weak and vacillating by the $\mathrm{CO}$ and who granted concessions to the settlers far beyond his authority to do so. This obviously did not go unseen by the Kenyan black population, who later formulated their own nationalist groups to work in their own self-interest and ultimately establish an independent black republic, thus putting a nail deep into the coffin of any prospects for a so-called "White Man's Country." Since the opening to the EAP, there was not yet a single British official capable of running the protectorate while efficiently reconciling the need to protect the Africans and Indians with the bold political demands of the settlers. Talks of European settlers paramountcy in the EAP was a lousy brouhaha, it was not a realistic agenda that took into consideration the ethnic composition of the country. The EAP at the beginning of the $20^{\text {th }}$ century was the least governable British

413 Ibid. 
dependency in the whole Empire. Any intent of favoring the late newcomers by any commissioner or governor sent by Whitehall was tantamount to a certain failure.

In the case of governor Girouard, who himself believed that unfair political formulation benefiting the settlers was going to remain without consequences; it was this kind of attitude that led to his downfall. Violations of Africans or Indians' rights, whether physical or discriminatory in the EAP, could not continue to be the news that the $\mathrm{CO}$ was receiving from the protectorate because anything leading to a political embarrassment was not desired at Whitehall. Political embarrassment was a sour pill to swallow because it could derail the political career of any official serving the British Empire in the EAP. That reality remains as such today in Kenya. Nevertheless, fifty years after gaining independence from Britain, Kenya's political leaders of today seem to have gotten drunk of power by using the inherited political chalice of impunity. 
BIBLIOGRAPHY

$$
\text { Primary Sources }
$$

Manuscripts

Great Britain, National Archives, Colonial Office Records, $\mathrm{CO} 533 / 4,5,14,15,16,24,25,28,29,33,42,43,62,63,67,71,74,76,88,89,90$, $102,103,115,193$.

Great Britain, National Archives, Foreign Office Records, FO 2/443, 447, 719, 720, 785, 807, 833, 835, 837 .

Government Publications

Great Britain, Government Documents

Correspondence Relating to Affairs in the East Africa Protectorate. Cd. 4122. London: HMSO, 1908.

Correspondence Relating to the Flogging of Natives by Certain Europeans at Nairobi. Cd. 3256. London: HMSO, 1907.

Papers Relating to British East Africa. House of Lords (HL) 158. London: HMSO, 1907.

Parliamentary Debates (Commons), Fifth Series (1907), 153.

Parliamentary Debates (Commons), Fifth Series (1912), 37.

Parliamentary Debates (Lords), Fifth Series (1907), 158.

Report by His Majesty's Special Commissioner on the Protectorate of Uganda. Cd. 671. London: HMSO, 1901.

Books

Churchill, Winston S. My African Journey. London: Holland Association Press, 1962.

Dissertations

Secondary Sources

Bhatt, P. M. "A History of Asians in Kenya, 1900-1970.” Ph.D. dissertation, Howard University, 1976. 
Berman, Bruce. "Administration and Politics in Colonial Kenya." Ph.D. dissertation, Yale University, 1973.

Cashmore, T. H. R. "Studies in District Administration in the East Africa Protectorate, 1895-1918.” Ph.D. dissertation, Cambridge University, 1965.

Sara, A. Daiyabu. "Rush to Failure: The Governorship of Sir Percy Girouard, 19091912.” Ph.D. dissertation, West Virginia University, 2013.

Books

Bennett, George. Kenya: A Political History. Nairobi: Oxford University Press, 1963.

Berman, Bruce. Control and Crisis in Colonial Kenya. Athens: Ohio University Press, 1990.

Buchan, John. The African Colony: Studies in the Reconstruction. London: William Blackwood and Sons, 1903.

Cole, Elanor. Random Recollections of a Pioneer Settler. Woodbridge, Suffolk: Baron Publishers, 1975.

Clayton, Anthony and Savage, Donald. C. Government aqnd Labour in Kenya, 18951963. London: Frank Cass, 1974.

Delamere, Lord. Grant of Land to the Zionist Congress. London: Harrison and Sons, 1903.

Dilley, M. R. British Policy in Kenya Colony. London: Frank Cass \& Co., Ltd., 1966.

Eliot, Sir Charles. East Africa Protectorate. New York: Barnes \& Nobles, 1966.

Foran, W. R. A Cuckoo in Kenya. London: Hutchinson, 1936.

Gregory, Robert G. India and East Africa. Oxford: Clarendon Press, 1970.

Grogan, E. S., and Sharp, A.H. From the Cape to Cairo. London: Hurst and Blackett, 1900.

Gunther, John. Inside Africa. New York: Harper, 1955.

Hindlip, Charles Allsopp. British East Africa: Past, Present and Future. London: T. Fisher Unwin, 1905.

Hobley, C. W. Kenya from Chartered Company to Crown Colony: Thirty Years of Exploration and Administration in British East Africa. London: H. F. and G. Witherby, 1929. 
Hobson, J. A. Imperialism: A Study. London: George Allen \& Unwin, 1902.

Huxley, Elspeth. White Man's Country- Lord Delamere and the Making of Kenya. New York: Macmillan, 1935.

Hyam, Ronald. Churchill and Elgin at the Colonial Office: 1905-1908. London: Macmillan, 1968.

Johnston, Sir Harry H. Colonization of Africa by Alien Races. Cambridge: University Press, 1899.

Leys, Norman. Kenya. London: Frank Cass and Company Limited, 1924.

Lugard, Frederick D. The Dual Mandate in British Tropical Africa. London: Frank Cass \& Co. Ltd, 1965. Original published in 1922.

Mangat, J.S. History of Asians in East Africa c. 1886-1945. Oxford: Clarendon Press, 1969 .

Maxon, Rober M. Britain and Kenya's Constitutions 1950-196o. Amherst: Cambria Press, 2011. America, 1980 . John Ainsworth and the Making of Kenya. Lanham: University Press of . Struggle for Kenya. London: Associated University Presses, 1993.

Mungeam, G. H. British Rule in Kenya, 1895-1912. Oxford: Clarendon Press, 1966.

Paice, Edward. Lost Lion of Empire. London: Harper Collins, 2001.

Reader, J. Africa: A Biography of the Continent. New York: Alfred A. Knopf, Inc., 1998.

Ross, William McGregor. Kenya from Within. London: Frank Cass and Company, Limited, 1968.

Shadle, Brett L. The Souls of White Folk: White Settlers in Kenya, 19oos-1920s. Manchester, UK: University Press, 2015.

Sorrenson, M. P. K. Origins of Settlement in Kenya. Nairobi: Oxford University Press, 1968. 
Dictionaries

Maxon, Robert M. and Ofcansky, Thomas P. Historical Dictionary of Kenya, $3^{\text {rd }}$ ed. Lanham: Rowman and Littlefield, 2014.

Journal Articles / Chapters

Anderson, David M. "Punishment, Race and 'The Raw Native:' Settler Society and Kenya's Flogging Scandals, 1895-1930,” Journal of Southern African Studies, 37:3 (2011).

“Sexual Threat and Settler Society: 'Black Perils' in Kenya, c. 1907-30," Journal of Imperial and Commonwealth History, 38:1 (2010).

Bennett, G. "Settlers and politics in Kenya," History of East Africa. 2, ed. Vincent Harlow, et al. Oxford: Clarendon, 1965.

Berman, Bruce and John Lonsdale. "Coping with the contradictions." In Unhappy Valley: Conflict in Kenya and Africa, Book One. London: James Currey, 1979.

Lonsdale, John. "The Conquest State, 1895-1904." In A Modern History of Africa, 1895- 1980, eited by W. R. Ochieng'. Nairobi: Evans Brothers, 1980.

---------- "The Moral Economy of Mau Mau: Wealth, Poverty and Civic Virtue in Kikuyu Political Thought." In Unhappy Valley: Conflict in Kenya and Africa. Book One. London: James Currey, 1992.

Maxon, Robert M. "Judgement on a Colonial Governor: Sir Percy Girouard in Kenya," Transafrican Journal of History, 18 (1989).

"Independent Kenya's Colonial Legacy." In A History of Independent Kenya: 1963-2013. A Celebration of Kenya's Fiftieth Independence Anniversary, edited by William R. Ochieng. Kisumu: Lake Publishers and Stationers, 2013, 1-39.

Shadle, Brett. "Settlers, Africans, and Inter-Personal Violence in Kenya, ca. 19001920s," International Journal of African Historical Studies, 45 (2012).

Sorrenson, M. P. K. "Land Policy in Kenya, 1895-1945." In History of East Africa. 2, ed.. edited by Vincent Harlow, et al. Oxford: Clarendon Press, 1965.

Waller, Richard. "Kenya's Contradictions: Control and Crisis in Colonial Kenya and the Dialectic of Domination," Journal of African History, 34. Cambridge University Press, 1993.

Wrigley, C. C. "Kenya: The Pattern of Economic Life, 1902-45." In History of East Africa. 2, ed., edited by Vincent Harlow, et al. Oxford: Clarendon Press, 1965. 
Newspapers

Advertiser, Adelaide, South Africa, 23 March 1906.

E. A. S., Nairobi, March-April -June 1908. February -May 1911.

Natal Witness, South Africa, 24 October 1903.

Times, London, 18 January 1905.

Standard Digital, Nairobi, November -December 2014.

Weekend Star, Nairobi, Kenya, 12 June 2014. 